\title{
Songs of the Empty place \\ The Memorial Poetry of the Foi of the Southern Highlands Province of Papua New Guinea
}





\title{
Songs of the Empty place \\ The Memorial Poetry of the Foi of the Southern Highlands Province of Papua New Guinea
}

\author{
James F. Weiner and Don Niles
}
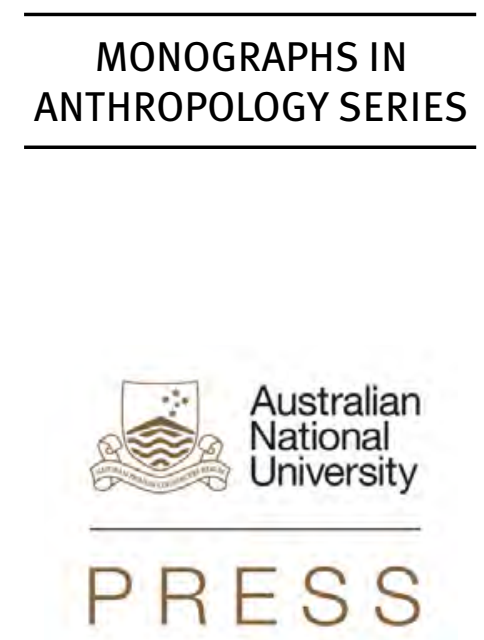


\section{ANU \\ PRESS}

Published by ANU Press

The Australian National University

Acton ACT 2601, Australia

Email: anupress@anu.edu.au

This title is also available online at http://press.anu.edu.au

National Library of Australia Cataloguing-in-Publication entry

Creator: Weiner, James F., author.

Title: $\quad$ Songs of the empty place : the memorial poetry of the Foi

of the Southern Highlands Province of

Papua New Guinea / James Weiner and Don

Niles.

ISBN:

9781925022223 (paperback) 9781925022230 (ebook)

Subjects: $\quad$ Foi (Papua New Guinean people)--Music.

Ethnomusicology--Papua New Guinea.

Folk music--Papua New Guinea.

Papua New Guinea--Songs and music.

Other Creators/Contributors:

Niles, Don, author.

Dewey Number: 781.629912

All rights reserved. No part of this publication may be reproduced, stored in a retrieval system or transmitted in any form or by any means, electronic, mechanical, photocopying or otherwise, without the prior permission of the publisher.

Cover design and layout by ANU Press

Printed by Griffin Press

This edition $(2) 2015$ ANU Press 


\section{Contents}

Acknowledgements vii

List of Illustrations $\quad$ ix

Preface: Singing the Earth in the Mubi Valley xi

Introduction: Foi Songs and the Performance, Publication, and Poetry of Papua New Guinea Sung Traditions xv

$\begin{array}{ll}\text { Women's Sago Songs (Obedobora) } & 1\end{array}$

Men's Songs (Sorohabora) 33

Women's Songs (Sorohabora) 133

$\begin{array}{ll}\text { Photographs } & 153\end{array}$

$\begin{array}{ll}\text { References } & 165\end{array}$

$\begin{array}{ll}\text { Index of Performers } & 183\end{array}$

List of Online Examples $\quad 185$ 



\section{Acknowledgements}

For this book, I undertook the original research that involved recording, transcribing, and translating the songs, as well as writing the introduction. Don Niles has contributed the other sections and edited the entire volume to bring it to its present form.

I would like to thank all of the Foi men and women, past and present, of Hegeso and Barutage villages whose compositions appear in this volume. I also thank Don Niles and the Institute of Papua New Guinea Studies for allowing me to bequeath these poetic songs to the Foi people, who have so graciously allowed me to live with and question them since 1979.

I also appreciate the efforts of Andrew McWilliam in seeing this submission through the ANU editorial committee for Anthropology in Pacific and Asian Studies, and to David Gardiner and Emily Tinker for assistance at ANU Press. Special thanks go to Nick Thieberger and others at the Pacific and Regional Archive for Digital Sources in Endangered Cultures (PARADISEC) for undertaking the digitisation of my audio recordings, thereby enabling examples to accompany this book.

James F. Weiner

Canberra, Australia 



\section{List of Illustrations}

\section{Figures}

Figure 1: The Foi and neighbouring peoples. xvi

Figure 2: Music transcription of sago song 2, lines 10-14. xix

Figure 3: Music transcription of sago song 6, lines 10-15. xx

Figure 4: The movement of male singers/dances

during sorohabora. xxiii

Figure 5: Music transcription of men's song 3, verse 2 . xxiv

Figure 6: Music transcription of women's sorohabora

song 2, lines 8-11. xxvii

\section{Photographs}

Photo 1: Dafimi (Barutage) and her mother making sago. 153

Photo 2: Kunuhuaka, her son Bebe, and James Weiner. 154

Photo 3: Hegeso longhouse. 154

Photo 4: Launching a new canoe. 155

Photo 5: View of Mubi River. 155

$\begin{array}{ll}\text { Photo 6: One of many small waterfalls. } & 156\end{array}$

$\begin{array}{ll}\text { Photo 7: Bush house. } & 156\end{array}$

Photo 8: Rock ledge near Segemi Creek. 157

Photo 9: Viya and his son Sese. 157

$\begin{array}{ll}\text { Photo 10: Large marsupial being butchered. } & 158\end{array}$

$\begin{array}{ll}\text { Photo 11: Kora of Hegeso. } & 158\end{array}$ 
Photo 12: Herebo longhouse.

Photo 13: Dancers outside of Herebo longhouse.

Photo 14: Hegeso longhouse.

Photo 15: Decorated Foi men.

Photo 16: Contingent of decorated Fasu men.

Photo 17: Fasu man in Bosavi-style ceremonial dress.

Photo 18: Hegeso men, sorohabora performance.

Photo 19: Abeabo of Hegeso.

Photo 20: Men playing gasore rattles. 


\title{
Preface
}

\section{Singing the Earth in the Mubi Valley}

\author{
James F. Weiner
}

In this book are found the transcripts of every song I recorded and transcribed while I was engaged in anthropological fieldwork in Hegeso village, Mubi River Valley, Southern Highlands Province (Figure 1). I spent a total of 31 months between 1979 and 1995 in Hegeso. A complete account of the practice of composing, singing, and performing these songs in their total ethnographic context can be found in my book The Empty Place: Poetry, Space and Being among the Foi of Papua New Guinea (1991) and I will not here go into any detail concerning the musicological or poetic structure of the songs. All of the songs I discussed in that book are included in this complete catalogue.

Most of them are men's ceremonial songs, called sorohabora, and nearly all were recorded during two major pig-kill festivals held in 1985 and 1988 in Hegeso village. The women's sago melodies were gathered more continuously during my field work in Hegeso and Barutage villages between 1979 and 1988.

In recording these songs, I found that I had to take a totally different approach to that which I employed when recording and translating Foi myth (see Weiner 1988a). I found that people would recite a myth anywhere at any time, and they did not need an audience to do so. Most of the myth texts I collected were done in my own residence under ostensive interview conditions. That is, I rarely recorded them as they were spontaneously recited in the longhouse or in other communal settings.

With the song poetry, on the other hand, this was not possible. They could only be recorded as they were performed. Even the sago songs, which women sing to themselves while at work processing sago flour, could not be collected in a state divorced from the woman's bodily work of pounding and shredding sago pith, which forms a rhythmic percussive accompaniment to her singing. Likewise, the men's ceremonial sorohabora are meant to be sung in groups, even though each man has a distinctive song and voice within the total group performance.

In other words, while they may lack the analytical and theoretical terminology to concretise such a contrast, I think the Foi are well aware of the various degrees to which speech forms, and different specialised varieties of speech, can or cannot be detached from their communal performative context. 
The three main forms of ceremonial song poetry are the women's sago songs (obedobora), the men's sorohabora, and the women's sorohabora. Women's sago songs are, in an important sense, work songs; they accompany the rhythmic work of sago shredding as a woman sits in front of a felled sago palm. Men too have their own work songs - I heard one man sing as he was hollowing out a new canoe - but they are not nearly as ubiquitous a part of men's work as they are of women's, because men engage in many fewer repetitive, rhythmic tasks of that sort.

As I described in The Empty Place, men turn the prosaic content of women's songs into their own songs, the sorohabora, which are performed the night following large-scale inter-community pig-kills, called dawa in Foi. While women sing by themselves, men sing in groups of paired men. Each pair of men sings a repertoire of between two and five songs in one evening, depending upon how many song groups there are. The pair of men is called the soro ira. About five or six pairs of men combine to form one soro ga. A large longhouse can accommodate up to twelve separate soro ga.

Besides the round-like, multiple-voiced structure of the men's performance, as opposed to the single voice of women's sago songs, the other major difference is that the men's version ends with what the Foi call the dawa or dawabo. This term is related to the verb dawaye gi-, 'to cut and give'. In this context, it refers to the end of the song, the last verse which 'cuts' the song off from the next one. The dawabo is the portion of the song where the names, both public and private, of the deceased are revealed, as well as the names and clan affiliations of his mother and father. Since the pig-kill and exchange ceremony, and the culminating, identifying portion of the sorohabora are called by the same term, dawa, we can take note of the importance of cutting or severing images in the most intensely public and ceremonial activities of Foi social life. Generalising, we can say that whenever the Foi perceive a flow - of pigs, pearl shells; of spatial movement over the land; the flow of words from the human voice - they see a potential for harnessing, cutting off, and redirecting that flow for human and social purposes. In my various interpretations of the Foi social world, I have made a case for the ubiquity of such imagery across a whole range of Foi social and expressive activities.

Women also told me that they have their own ceremonial version of these songs, though I never saw them performed under actual ceremonial conditions. If the men are copying the women's sago songs to make their own sorohabora, then it appears as if women are copying the men's copies of their original songs. Several of these songs, which were performed for me under non-ceremonial circumstances, are also included in this collection. 
The subject of nearly all these songs is deceased men. The songs are memorial in intent; they are designed to commemorate the lives of men who are no longer living. Most commonly they do so by naming the places the deceased inhabited during his lifetime.

These places are chiefly those in that part of the Foi territory devoted exclusively to hunting. In Hegeso, this region was called Ayamo, and I am still unsure whether this is a generic term for 'hunting preserve' or a named part of the Hegeso territory where this activity takes place. The term appears to function as both for the Foi of Hegeso.

Men leave their traces in the forest by erecting houses and other shelters and building traps. These constitute the marks of human life in the segment of their territory where no one lives permanently and is largely seasonally visited. The traces in the land of men's presence disappear rapidly at Ayamo under such intermittent use. When a man dies, he is no longer able to renew the vivacity of these traces. They begin to be eroded and covered over by the encroaching forest. An abandoned house being given over to the forest is a poignant image of death in Foi.

In addition to the abandonment that Foi people feel when a close relative dies, they give expression to similar sentiments when their living relatives leave the area for long periods of time, a condition that, by 1995, was becoming more and more common as opportunities for mobility in Papua New Guinea were increasing for everyone. One woman thus sings of her eldest son, serving with the Papua New Guinea Defence Force in Manus Province.

However, as the texts below indicate, the songs are used to convey other messages. Reminiscent of the neighbouring Kewa (see LeRoy 1978), some of the songs convey politically competitive feelings between men of different villages; women also use the songs to complain about their mistreatment at the hands of men.

The most common prosaic property of these songs is to list the names of places in the local territory which the deceased inhabited during his lifetime. The lifespan of the individual man is thus rendered spatially as a sequence of occupied places, and these places constitute a track or trace through that territory. Theoretically, so I was told, a full longhouse of performers would recite the name of every deceased man of the longhouse and by implication the name of every place in the territory (or at least the hunting territory) inhabited by those men. The performance of the sorohabora thus can be seen as a poetic or narrative constitution or totalisation of the community of men as a whole, a series of lives rendered as a temporal sequence of inhabited and inhabitable places in 
the productive imagination. But it effects this retotalisation out of a prior act of discursive disassembly - detotalising the territory into its constituent life tracks, which each constitute the lifespan of a single man.

What is the future of this most powerful expressive form in Foi? My last trip to Hegeso for my own research purposes was in December 1994-January 1995. For the first time since I began visiting the Foi, no sorohabora performances occurred during the Christmas holiday season in any of the Mubi Valley villages, even though this is ordinarily a time that is reserved for pig-kills and ceremony. Since that time I have visited Hegeso regularly, if briefly, in the course of conducting social mapping, landowner identification, and other related consultancy work for various companies which have comprised the Kutubu petroleum and LNG Joint Venture Partnership between 1999 and the present.

I do not wish to be too precipitous in forecasting that the practice of Foi song composition and performance is now on the wane. Still, string instruments, and the learning and singing of string band music were more popular among young men in 1995 than they were in 1988, and I suspect that there will be more occasions for more national, 'generically' Papua New Guinean ceremonies and festivities in the Foi region, now that there has been a sharp increase in the number of non-Foi living in the area. What this will mean for the composition, learning, practising, transmission, and performance of traditional Foi memorial songs remains to be seen. I welcome current students of anthropology, linguistics, verbal art, aesthetics, cultural heritage, and ethnomusicology to give an account of the future of the Foi memorial poetic song. 


\title{
Introduction
}

\section{Foi Songs and the Performance, Publication, and Poetry of Papua New Guinea Sung Traditions}

\author{
Don Niles
}

I am very pleased and honoured to introduce James Weiner's book of Foi song texts. This gives me an opportunity to discuss why I think this is such a valuable publication and to highlight its importance in relation to various topics of concern to Papua New Guinea ethnomusicology.

Weiner's book The Empty Place: Poetry, Space, and Being among the Foi of Papua New Guinea (1991) discusses many of the song texts in this present volume and shows how they highlight or relate to certain aspects of Foi society. A number of reviews of the book appeared (e.g. Reesink 1992; Turner 1993), including a review article focusing on Weiner's approach through philosophers such as Heidegger and Merleau-Ponty (Mimica 1993; see also the reply in Weiner 1993).

Foi speakers of Southern Highlands Province today number about 6,000-8,000, living in the vicinity of Lake Kutubu (the Gurubumena) and along the Mubi River to the east (Awamena) and southeast (Foimena) (Figure 1). The Foi of Hegeso, where the majority of Weiner's research was done between 1979 and 1989, call their region awa hao 'the empty place', because of the absence of meat there in contrast to other regions (Weiner 1991:22). The traditional residential unit for the Foi is the longhouse community ( $a$ hũa 'house mother'), a central communal longhouse with smaller individual women's houses on each side. In 1980, Hegeso had a population of 266 (Weiner 1988a:23).

Linguistically, Foi is a member of the East Kutubu group of the Trans-New Guinea family. The only other member of this group is Fiwaga, spoken to the southeast. ${ }^{1}$ The Fasu language, to the west, is the sole member of the West Kutubu group and even further to the west is the Bosavi group; to the north and east of the Foi are languages of the Engan group, all belonging to the Trans-New Guinea family (M. P. Lewis et al. 2013). Except for Fiwaga, none of these languages is closely related to Foi.

\footnotetext{
1 The impression shared by Weiner and many Foi speakers, however, is that Foi and Fiwaga should be regarded as one language.
} 
In 1986, exploration near Lake Kutubu suggested oil existed in quantities large enough to warrant the development of an oilfield. Production of the Kutubu Oil Project began in June 1992 as the country's first commercial oilfield development. It is run by Oil Search Limited (Busse et al. 1993:21; Oil Search Limited 2012). Today, the Kutubu area may be featured in articles directed towards potential tourists (e.g. Brooksbank 2012) or in local television segments.

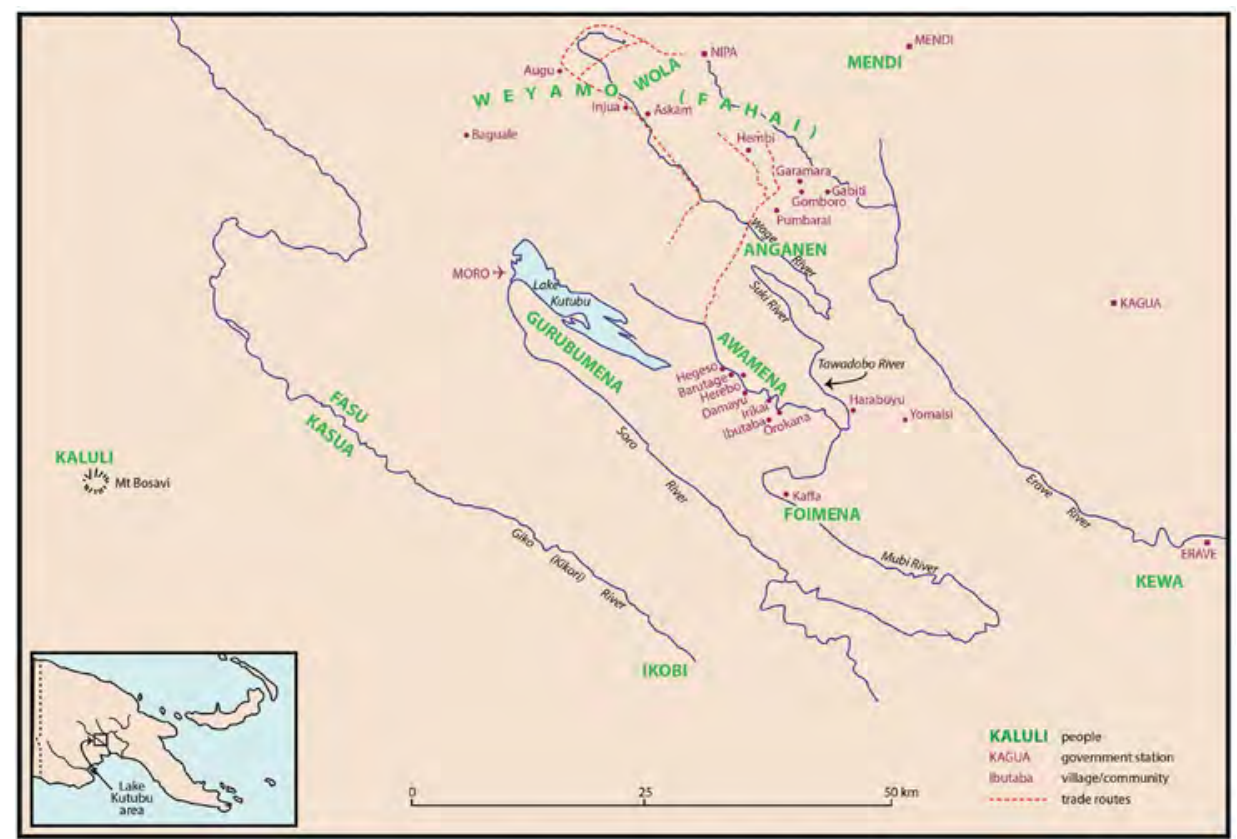

Figure 1: The Foi and neighbouring peoples.

Source: Based on Weiner 1988a:20 (map 1), 36 (map 2); 1991:23 (map 1-1), 24 (map 1-2).

\section{Foi songs in the present volume}

The song texts and translations in this volume are divided into three sections, based on the genre concerned and gender of the performers involved. I follow this division here.

\section{Women's sago songs (obedobora)}

A man fells a mature sago tree, 15-20 years after the sucker first appears, and then strips off the outer bark. This completes his involvement in the process. His wife and any female helper make a bench from the bark, so that she may sit at a right angle to the palm. With her knees slightly drawn up, she simultaneously 
hits and scrapes the exposed pith with a piece of obsidian hafted into a wooden mallet. She sings obedobora songs as she repeatedly lifts her arms, strikes, and scrapes the pith. Although often sung solo, a second woman may echo the sung lines a few beats later, as is the case with sago songs 6-7 in this collection (Weiner 1991:119-20, 134). ${ }^{2}$

The name obedobora 'obe talk' comes from the vocables commonly attached to the ends of lines of such songs. ${ }^{3}$ For example abu biri-o, obe-u! a'a mae, obe-u 'sago mallet, oh, obe-u! make sago quickly, obe-u!' The Foi consider obedobora to be their original poetic medium; men's sorohabora songs are derived from them (ibid. 1988a:131-32; 1991:120).

In the last few lines of her song, the woman may sing the dawa, in which the subject of the song is identified and the song is ended. In men's sorohabora, the word 'dawa' or a variation of it is prominently sung; in sago songs, this subjectrevealing section may be absent (Weiner 1991:137-38). For this reason, further information about the dawa is given in the discussion of men's songs below.

The turning on and off of Weiner's tape recorder made the singers provide a start and finish to their songs and an uninterrupted performance. While the result enabled easier documentation of the genre, the artificiality is also apparent; the normal soundscape is much more complicated:

A more accurate aural image of women's singing can be obtained by walking through the swamps and pausing to listen to nearby women without actually approaching their sago camps. There, you hear snatches of a refrain, then perhaps a fragment of a wordless falsetto croon, a silence and the strong breathing of heavy exertion, the sound of a baby crying, sometimes the laughing and chatter of two women talking and gossiping as they work together, and through it all, the stop and start of the dull thud of the sago mallet and the wet thwack! of the pith-beating stick. (Weiner 1991:153)

Obedobora are work songs, sung by women to urge themselves on to complete the task quickly (Weiner 1991:119-20). But sago songs are also songs of mourning. They are primarily sung to memorialise departed kinsmen:

\footnotetext{
2 Information about such songs is primarily found in Weiner (1988a:131-35; 1991:116-50). By way of comparison, Kaluli women sing heyalo and other song genres while scraping sago (Feld 1981:A2; 1985:B7; 2001:disc 2, nos 2-3), and such songs are also performed at other times of work or relaxation. Kaluli have no specific song form for scraping sago.

3 Other frequent vocables as seen in the corpus of obedobora collected here are owe, owa, oye, eye, and eya (Weiner 1988a:302, n. 4). Note that such vocables are omitted when obedobora are made into sorohabora. Another name for obedobora is dima (Weiner 1991:104; Rule 1993:89). During brief fieldwork in 2013, Hahudi Farobo (from Daga village) explained to us that a generic name for such songs is kui dima dobora 'sago-beating song'. Obedobora refers more specifically to songs using obe vocables, typical of the area in which Weiner worked (Niles and Gende 2013).
} 
The memory of dead kinsmen is a constant and engaging conceptualization for the Foi; the sound and sights of the forest and the innumerable creeks and rivers where one shared one's life and experience with the departed emerge as poignant evidence of a landscape now rendered empty by the loss of those who quickened it through the significant and 'concernful' acts of living.

Thus, sago melodies [obedobora] all begin as mourning songs; though they become thematically more varied, the 'poetics of loss and abandonment' remain a substrate of imagery throughout the entire range of song themes. (Weiner 1991:22)

At a death, mourning songs are sung by women inside the longhouse. The corpse is placed in the centre of the central corridor, surrounded by seated women who huddle over it, caress it, sway towards and away from it, while wailing and shaking rattles. This scene contrasts dramatically with the performance of men's sorohabora, described below (Weiner 1991:151-52).

In their sago songs, women sing of their deceased or absent husbands and male kinsmen, immortalising these men as they lived (Weiner 1991:118). Hence, these obedobora and the men's sorohabora derived from them are considered mourning songs, created to associate the memory of deceased men with the territories they used to frequent. Each song is composed by an individual woman, and she may pass her songs on to her children. These memorial songs trace the geographical and genealogical route of a person's life, the two being considered metaphorically equivalent (ibid.:118, 132, 134-35):

Women, in singing about the deaths and departures of their husbands and male relatives and the mistreatment they bear at the hands of men, contrive to represent the terms of their own feminine alienation from what must often strike them as the fatuity of men's striving. When men appropriate these songs for their own ceremonial purposes, then, they not only give expression to their own feelings of loss and abandonment, they confirm the importance of women's representation of their own male world. (Weiner 1991:146-47)

Figure 2 shows my transcription of lines 10-14 of sago song 2 . D is the tonal centre, here the lowest pitch used. Note the closing melodic descent G-E-D, which is often sung on vocables and at a slower pace than the other parts of the text. Indeed, each phrase ends with a descent from $\mathrm{C}$ to the tonal centre and lowest pitch (D). Text before this descent is sung between pitches A and C. While the sago pounder provides a pulse at around $41 \mathrm{bpm},{ }^{4}$ it is irregular as

4 Comparing some of the other sago songs, the sago mallet provides a pulse of around $41-63 \mathrm{bpm}$. Note also the transcription of a sago song by Cathy O'Sullivan (Weiner 1991:xiv, 148-50). 
the time between hits is variable. Because this pulse is so slow, the transcription uses a tempo derived from the rather evenly spaced quarter notes (crotchets) frequently found in the G-E-D figure.
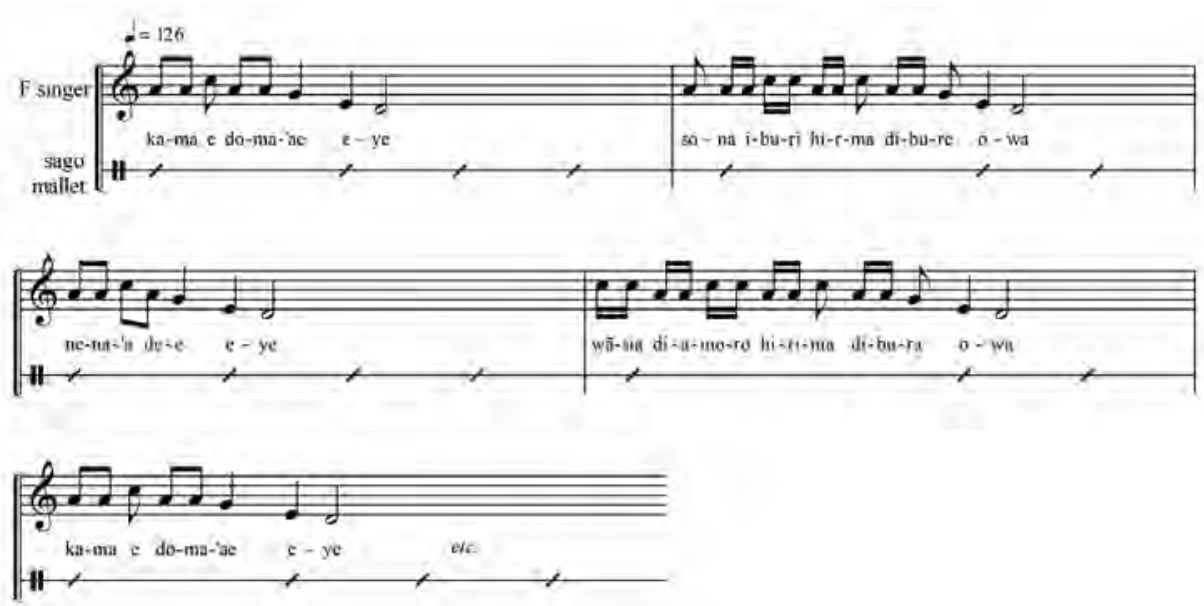

Figure 2: Music transcription of sago song 2, lines 10-14 (see online example 1).

For comparison, a transcription of lines 10-15 of sago song 6, sung by two women, is given in Figure 3. Again, the tonal centre is transcribed as D. The scale used and general shape of the melody is very similar to that used in the solo sago song. In this example, though, lines and their melodic presentations are grouped in threes, and as the first woman sings a line of text, it is partially echoed by the second woman. The first line of such a group has different text each time it is sung; the second line is sung in one of two closely related forms ( $n a^{\prime} a$ ibiba'ae or ne ibiba'ae), and the third line is textually and musically always the same (eye). As the first-line text is variable, the second woman usually only sings the end of this line; she sings the second and third lines with the first woman, in a style that is very similar to the Kaluli, simultaneously in-synchrony while out-of-phase (Feld 1988:82), although it is not known to what extent the same performance aesthetics are followed here. Note also that the striking of the women's sago mallets is not in unison. These strikes are only roughly indicated in the transcription. 

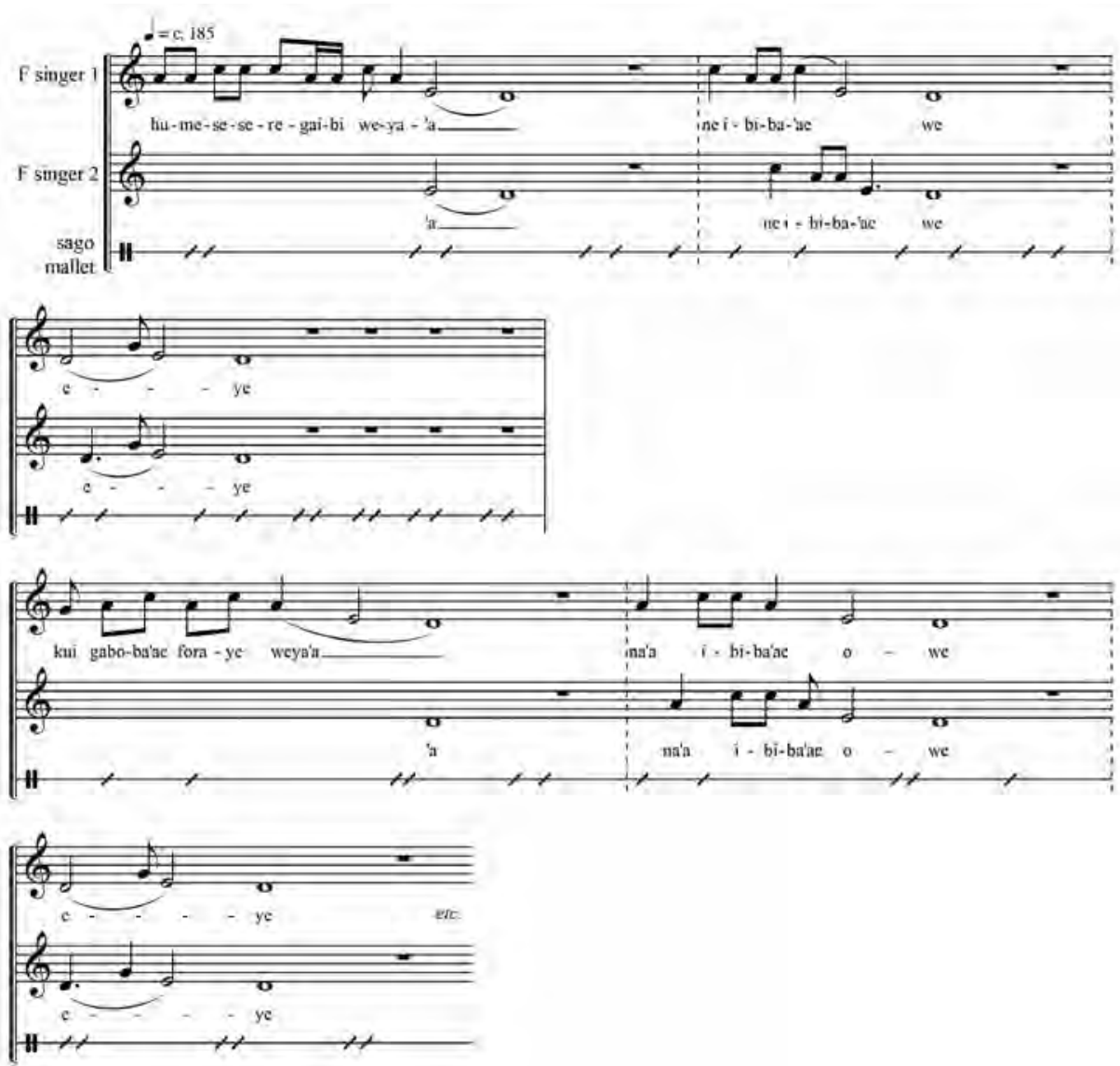

Figure 3: Music transcription of sago song 6, lines 10-15 (see online example 6).

I will now consider men's sorohabora, the men's transformation of women's obedobora for ceremonial performance.

\section{Men's songs (sorohabora)}

Men hear women's sago songs (obedobora) when they go tap kara'o oil from Campnosperma brevipetiolata trees, and at other times when they are walking in the bush (Weiner 1991:153). The men condense and compress the images of the poetry of the women's songs, just as poetry does to discourse, and dance is the poetic rendition of everyday movement. Thus, 'poetry, song, and dance are ... different facets of ... the aesthetic embodiment of discourse in its most encompassing, inscriptive sense' (ibid.:154). 
The men say, 'these songs belong to the women. When we perform our sorohabora chants, we are merely imitating the women' (ibid. 1988a:131-32). Yet, aside from context, the transformation from women's obedobora to men's sorohabora requires various modifications to structure and performance practice. ${ }^{5}$

Men formerly performed sorohabora to promote general fertility and ensure success in hunting during $b i^{\prime} a^{\prime} a$ guabora rites for the inauguration of a new longhouse. Sorohabora were performed by men returning with meat to the new longhouse. Each man began to dance as he entered the longhouse. Additionally, sorohabora were performed during the night of the pig-kill that celebrated the completion of bi'a'a guabora (Weiner 1991:190-93). In the decade including Weiner's primary fieldwork in Hegeso between 1979 and 1989, sorohabora were commonly performed after the completion of ceremonial pig and shell wealth exchanges.

While women's sago songs are usually sung solo, men's songs are always sung by a pair of men called soro ira 'song tree'. ${ }^{6}$ These men often practise and sing together; consequently, they are very familiar with each other's performance styles. If the lines of a woman's obedobora are $a b c d$, men in a soro ira perform them as $a_{1} c_{2} b_{1} d_{2^{\prime}}$ with the subscripts showing which member of the pair sings a particular line. ${ }^{7}$ As a result of this alteration, the first two lines $\left(a_{1}, c_{2}\right)$ produce a couplet that contrasts in content with the couplet produced by the last two lines $\left(b_{1}, d_{2}\right)$ :

The first line of the male-produced couplet describes an image of life: an animal trap in the bush, a spell or myth habitually recited, a canoe moving along the river. It identifies a previous condition of active, moving 'life-lihood'. The second line offers a contrasting assertion of what has happened to that previously vital condition: an abandoned bush track, a spell forgotten and not passed on to other men, a fallen tree. It offers a view of life's finality. The couplet form thus quite elementarily juxtaposes the most incisive Foi images of motion and the end of motion, itself the most encompassing image of the transition between vitality and mortality. (Weiner 1991:155; see also, Weiner 1998b)

\footnotetext{
5 Rule (1993:136) writes sorohabora as two words - soro 'song'; soro ha- 'sing a song'; soro habora 'a ceremonial song' - thereby emphasising its relation to the word for 'song' (also see Weiner 1991:154). Weiner (pers. comm., 2 Oct 2012) observes that the -bora participial ending to soro ha- makes a noun out of a verb, hence, sorohabora is literally the 'soro-ing' or 'soro making.'

6 The descriptions from here until the end of the section on men's sorohabora primarily derive from material presented in Weiner (1991:154-59; 1998b; 2001:39-43), supplemented where possible by additional research. 7 In Weiner (1991), compare the presentation of verses as sung on pp. 171-75 (hence, using the notation followed here: $\left.a_{1} c_{2} b_{1} d_{2}\right)$, with those on pp. 176-81, which keep together each man's pair of lines $\left(a_{1} b_{1} c_{2} d_{2}\right)$. While the former arrangement follows the style of performance, the latter allows better understanding of the poetry. The songs presented there correspond to men's songs 3, 8, and 10 in the present collection. In this collection, each singer's pairs of lines are similarly preserved, rather than following the order of those lines during performance.
} 
Men do not sing the 'owe' and 'eye' vocables that frequently end lines in women's sago songs; rather, men sing 'dawa' or a variation of this towards the end of their songs, as described below in more detail.

The men in each soro ira pair face each other; their skins bright from kara'o tree oil, face paint, and the feathers on their heads (Weiner 1988a:152). Between three and seven soro ira make up a soro ga 'song base', which sings as a group (Figure 4a). ${ }^{8}$ Sorohabora songs typically consist of five verses (the songs in this collection vary between four, five, and six verses), with each verse containing four lines (= two couplets) of text. In a typical performance by the first soro ira of a soro ga, the first man sings the first line of his couplet $\left(a_{1}\right)$, which descends to the tonal centre (the lowest pitch in the phrase) and is sustained. While this pitch is sustained, his partner then sings the first line of his text $\left(c_{2}\right)$, descending to and sustaining the tonal centre, thereby singing the tonal centre in unison with the first singer. While the second man continues to sustain the tonal centre, the first man then sings the concluding line of his couplet $\left(b_{1}\right)$ and sustains the tonal centre; the second singer then sings his own final line $\left(d_{2}\right)$, descending to the tonal centre and sustaining it with his partner. An 'ululation' or 'bleating' is often sung on the pitch above the tonal centre on each sung descent, but not on the lowest pitch (the tonal centre). ${ }^{9}$ At the end of the verse, both singers sustain the tonal centre in unison for an extended period of time. Note that the contrast of the two male-produced couplets $\left(a_{1}, c_{2} ; b_{1}, d_{2}\right)$ as described above is also maintained in their sung representation.

\footnotetext{
8 The soro ira is to the soro ga as the lineage (ira also means 'lineage') is to the clan. The soro ga is a miniature version of the clan, men's most important social identity, but not a reflection of it. Soro ira and soro ga are poetic images of Foi social identities (Weiner 1991:159).

9 In Eunice Loeweke and Jean May's 1960-64 description of Fasu namo kesa, they refer to this sound as a 'breathy, quavering vibrato [that] occurs on the second note of the scale' (Chenoweth 2000:187). In Loeweke's accompanying music transcription of namo kesa, it is notated with two dots over the note in question (ibid.:188-92). Preliminary spectrographic analysis shows that the 'bleating' in Foi songs is indeed frequency modulation, hence vibrato. In some of the examples considered, there are about 10 pulsations per second, with a variation of about 150 cents from the highest to lowest frequencies. The tonal centre in sorohabora songs and in the Fasu example mentioned is the lowest pitch; in both cases, bleating appears to occur only on the pitch immediately above the tonal centre. I appreciate the assistance of Julia Colleen Miller, Philip Rose, and Alan Rumsey for discussion leading towards this initial assessment.
} 


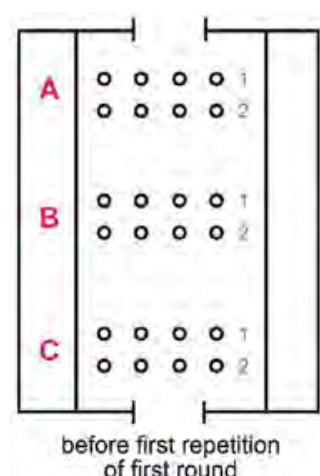

(a)
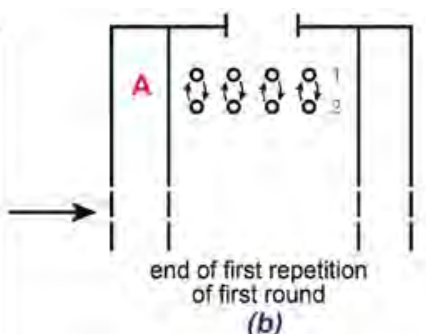

(b)

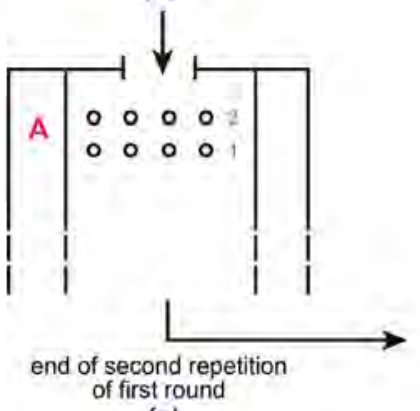

(c)
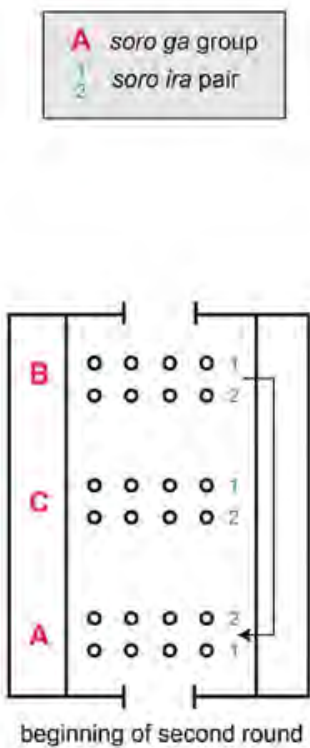

(d)

\section{Figure 4: The movement of male singers/dances during sorohabora.}

Source: Adapted from Weiner 1991:157, fig. 7-1.

At the conclusion of the first pair's first verse, the second soro ira performs the first verse of their song in the same manner. After the conclusion of the second pair's first verse, the third pair sings their first verse, and so on until all soro ira have performed their first verses. The first soro ira now performs their second verse in the same manner, their second verse is followed by the second soro ira's second verse, and so forth. Such alternation continues for all the verses of each soro ira's song. The singing of all verses of each song is one round of singing.

Men dance by bobbing up and down in a steady rhythm, bending at the knees, but keeping their backs straight, during their own singing and while they are waiting to sing. ${ }^{10}$ In one hand a man may hold a bundle of arrows (yaba) plus a bow $\left(b i^{\prime} a\right)$, a spear $(t a b u)$, or a heavy stick of some kind. These are struck on the floor in time to the bobbing, thus providing a pulse. A man often begins a sung line by strongly stamping his heel down on the first syllable. One or two men in

10 While the characteristic position of men is standing up, opening up the chest and upper torso, with the arms providing rhythm, that for women is sitting, with an emphasis on closing up of the central body area. Women's singing and wailing takes place in such a position, with their legs bent upwards towards the body (as when making sago) or folded under their buttocks (as when sitting cross-legged next to a corpse in the longhouse) (Weiner 1991:156). 
each soro ga shake a vessel rattle consisting of dried seeds inside cylindrical seed pods tied together (gasore). ${ }^{11}$ This rattle is shaken to the rhythm of the bobbing and the instruments struck on the floor, all providing a pulse to the singing.

Comparing the pulse of the striking of a woman's mallet as she sings while preparing sago with the pulse of the rattle or other struck object in men's sorohabora songs, the former songs are between about 41 and $63 \mathrm{bpm}$, while the latter are between about 144 and 175 bpm; hence, the pulse of the latter is about two or three times faster than in women's sago songs. Nevertheless, the speed of the sung text in both genres appears to be similar.

Verse 2 of men's song 3 is transcribed in Figure 5. While this is the same song as more fully transcribed by Cathy O'Sullivan (Weiner 1991:176-81), my transcription attempts to show more clearly how the paired singers interact musically. The tonal centre here is transcribed as D. It is always the lowest note in performances. Note how most sung phrases descend to this $\mathrm{D}$, which is then sustained while the other singer sings his next line of text. The length of these sustained final pitches is indicated in seconds in the transcription. (The first singer here neither descends to D on his first line nor sustains any phrase-final final pitch; this is another variation of performance style.) This type of multipart organisation differs considerably from the other genres of Foi music considered here.
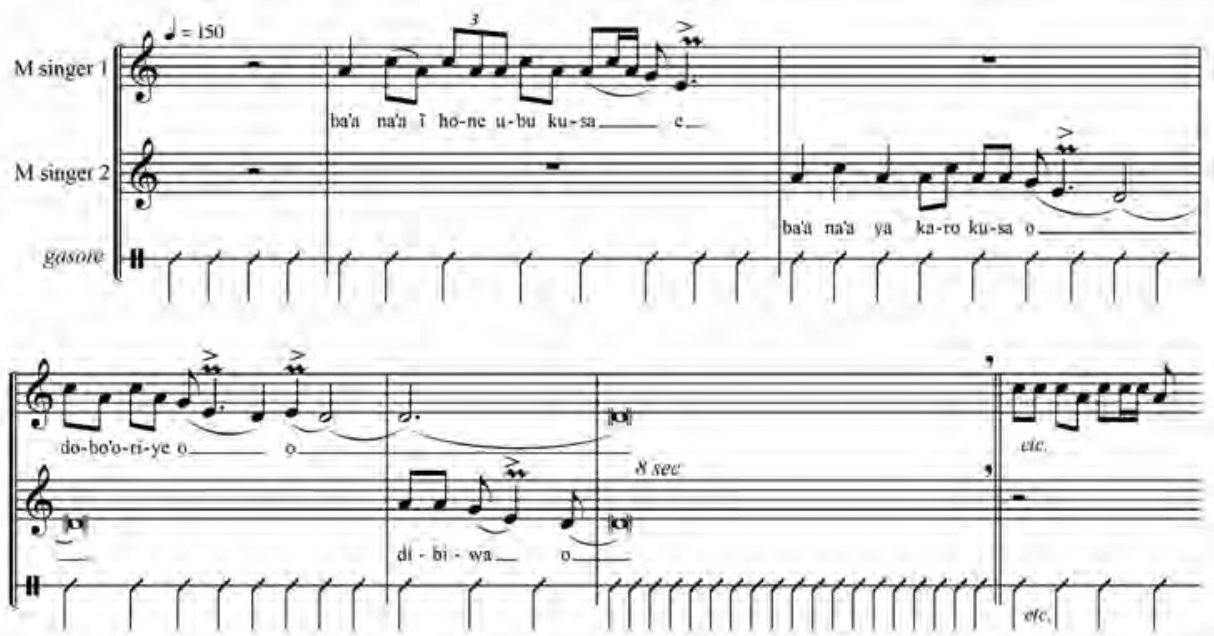

Figure 5: Music transcription of men's song 3, verse 2 (see $/ \mathcal{J}$ online example 9).

11 Rule (1993:16, 98) also calls the rattle gasore, while Williams (1940-42:149-50; 1977:194) writes gasoro and notes that it might be attached to handle - a variation I also observed in 2013. It is very likely that there is a semantic relation between the soro ga and the gasore/gasoro instrument they play (Weiner, pers. comm., 2 Oct 2012). 
The 'bleated' note (indicated with a mordent above the note in question in my transcription) is on $\mathrm{E}$ and usually directly precedes descent to the tonal centre. The 'bleating' is always sung more loudly than other parts of the melody, sometimes significantly so. In further contrast to the accentuated frequencymodulated 'bleating' that forms a harmonic major second with the other sung and sustained part, the subsequent unison on D is often sung at a softer volume and is always sung as a stable pitch (i.e. not 'bleated'). Extended final vowels or vowel vocables are sung on these final pitches of a phrase. Finally, note the extended sustained unison at the end of this verse. While the exact length is, of course, variable, there is always an extended unison at such points.

The first three verses of each song are often about places - the names of mountains, streams, sago swamps, etc.; the last two verses reveal the identity of the man being sung about, the owner of or visitor to the places previously mentioned. Often the man's non-public name is sung, or perhaps only the clans of his parents (Weiner 1991:137-38); his everyday name is never revealed in songs. These last two verses are called the dawa or dawadobora, a word that means 'to cut up (and distribute)'. Dawa is the Foi name for the recently imported festival where pork is cut up and given away to mark the end of a ceremonial exchange. In men's sorohabora, the dawa of the song 'cuts off' the song from the one that follows and 'gives away' the name of the deceased man to the public. The actual singing of the word 'dawa' or 'dawabo' frequently occurs during these last two verses.

After the singing of one round of songs (i.e. each soro ira in the soro ga completing all the verses of their songs), each man changes position with his soro ira partner (Figures $4 \mathrm{~b}-\mathrm{c}$ ). They then repeat the same songs, in the same manner as was done previously. At the end of this repetition of songs, the men stamp their feet vigorously, and the two lines of men in each soro ga form a single line and move to the position in the longhouse that was occupied by the soro ga adjacent to them. The soro ga at one end of the longhouse moves to the other end. In some performances, groups first move from the front to the back of the longhouse and then back again (Figure 4d).

In larger longhouses, 10-12 soro ga can participate simultaneously. If there are many pairs of men in a soro ga, the number of verses per song may be reduced from five to as few as two in order to allow all songs to be completed during the night.

As dawn approaches, one soro ira assumes leadership of all the performers in the longhouse, having either been selected beforehand or chosen during the night. The men now consider themselves one soro ga. Each pair will now sing one pair of lines as the performers leave the longhouse and descend to the plaza at sunrise. 


\section{Women's sorohabora}

Women told Weiner that they performed their own sorohabora in women's houses while the men were singing in the longhouse, but he never witnessed this during the ceremonial performances he attended. Nevertheless, one night he separately recorded the seven women's sorohabora included in this collection. They were all performed by pairs of women. One woman would begin a line and her partner would sing the same line, one beat later - this is quite different from the men's performances where a singer's partner sings a different text at the conclusion of a line. The women's sorohabora-performance technique of echoing the text of the first singer is similar to that used by two women to perform a sago song, such as occurs in sago song 6, where Kunuhuaka sings a line that is repeated three beats later by Siyame (cf. Figure 3). In women's sorohabora as in the men's, the owe and eye vocables of sago songs are not sung, but dawa verses are included (Weiner 1991:134, 146).

Figure 6 is a transcription of lines $8-11$ of the women's sorohabora song no. 2 . No gasore rattle or any other instrument is used to provide a pulse. Aside from the differences between men's and women's performance styles in sorohabora noted above, final tonal centres in unison are sustained at length in both genres. However, at the conclusion of these sustained notes, men tend to start the next verse immediately; in women's performances, however, there is a long pause before singing resumes. Lengths of these sustained tonal centres and pauses are indicated in seconds on the transcriptions. Women also do not 'bleat' pitches on the second-lowest pitch as men do.

\section{Relation to other studies of music in Papua New Guinea}

With the above introduction to the Foi genres documented in this collection, I will now consider some particularly salient aspects of how this research, particularly on men's sorohabora, augments other comparable work in Papua New Guinea. This enables a reader and listener to better appreciate how the Foi relate to their neighbours, and also how this particular study adds to our knowledge of certain types of performance traditions in this country. 

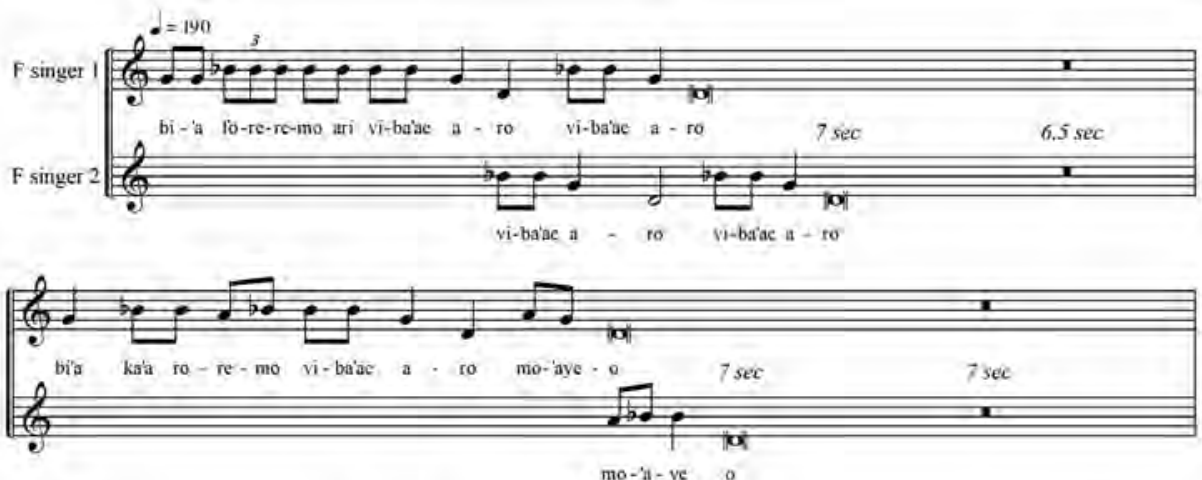

mo-ill-ye o

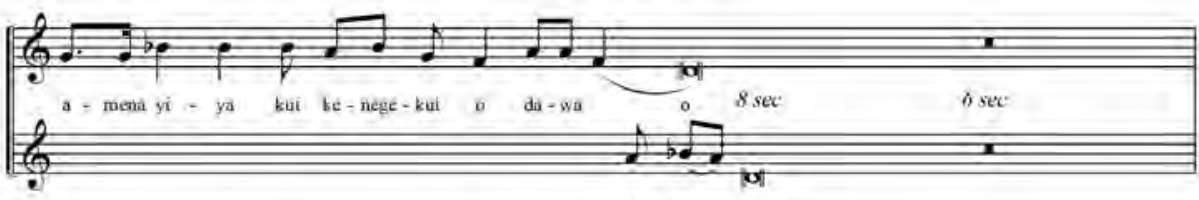

dà - wa - a

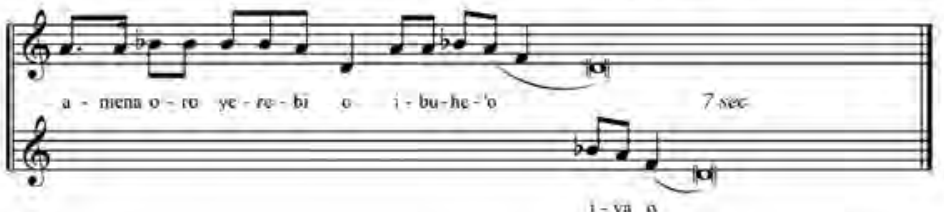

$1-y+1$

Figure 6: Music transcription of women's sorohabora song 2, lines 8-11 (see J online example 14).

A noteworthy aspect of Foi men's sorohabora is its indoor performance at night; an outstanding feature of this particular publication is its presentation of Foi song texts. I will consider each of these subjects in turn and consider related work from other parts of the country.

\section{Indoor, nocturnal performances}

Nocturnal ceremonial music/dance performances inside longhouses appear to be a key element distinguishing groups that are often felt to be part of the Highlands fringe, that is, groups that are in various ways culturally distinct from those of the main Highlands region. ${ }^{12}$ Of course, which groups are core and which are fringe is not always easy to define, nor is it easy to list distinguishing traits (Weiner 1988b; A. Strathern 1988; Hays 1993). Yet, certainly throughout the main Highlands area-stretching from the central parts of Hela, Southern Highlands, Enga, Western Highlands, Jiwaka, Chimbu, and Eastern Highlands

12 In some areas, there is a mixture of different performance contexts. For example, Kirsch (1987:2) observes that Yongom (Yonggom) dances are differentiated on the basis of their performance inside or outside, during the day or night, and by men or by men and women. 
provinces - most music/dance performances by groups take place outside during the day, often in a special area cleared for dancing. ${ }^{13}$ In contrast, among the Foi and other groups, performances are usually inside and at night. ${ }^{14}$

There is not a total absence of indoor, nocturnal performances in the main Highlands area. Throughout much of this region from Duna in the west all the way to eastern portions of Eastern Highlands Province, courting activities, frequently involving sitting dances, also take place indoors and at night (e.g. see Stewart and Strathern 2002:29-90). However, courting dances do not have the ceremonial import of the indoor dances performed by the southern 'fringe' groups. Furthermore, decorations for courting are also often rather simple, dances are done while seated, and the singing appears to always be a cappella. In contrast, decorations for ceremonial performances inside longhouses are usually elaborate, dancers stand and move to different positions inside the house, and the singing is always accompanied by an instrument, usually a rattle, but sometimes a drum.

Groups neighbouring the Foi to the east and particularly to the west, as well as some located more distantly from them, all perform indoor ceremonial dancing at night, although the details of the performance itself, the decorations, who sings, what instrument is used, etc., may differ. In spite of these variations, however, the contrast of such a genre with the outdoor, daytime performances widely practised in the central part of the Highlands remains striking.

Researchers have written about a number of groups who claim to perform songs and dances originally from the 'Kutubu area'. While definitely including Foi speakers, the term 'Kutubu area' may also include the Fasu, immediately to the west of the Foi. The Fasu are middle men in the borrowing of traits between the Foi and Bosavi groups farther to the west (Weiner 1988a:21). The Fasu perform namo kesa 'essence song' inside their communal longhouse at night during the final distribution of brideprice to the bride's relatives, completion of a new longhouse, pig feast, the final moving of a deceased's bones to a cave, or when the killers of a witch responsible for a death give compensation to the witch's relatives. ${ }^{15}$ In contrast to the Foi sorohabora, women do not watch.

13 In spite of the differences between Highlands and Highlands fringe, there can still be appreciation of contrasting traditions. Knauft (1985b:328, pers. comm. from Laurence Goldman) reports that Huli invite contingents of Dugube (their 'fringe' neighbours to the south) to stay with them for extended periods of time and perform their rituals. A dance called hewabi bi by the Huli 'appears to derive from the Lake Kutubu region' and involves large fronds of sago palm worn at the back of the dancers, 'very reminiscent of Papuan Plateau dancers' (Goldman 2007:159, table 9.2). Goldman does not mention if any musical instruments are part of such performances, but it would be very interesting if rattles were used as such instruments are otherwise not played in Huli performance.

14 Bruce Knauft identifies common features of rituals in the Strickland-Bosavi region: all-night dances in longhouses, dance costumes, movements, etc. (1985b:324-27), but also considers contrasts. As will be seen from the discussion below, I suggest that this region of commonalities extends over a significantly wider area. 15 A recording of namo kesa is found in Niles and Webb (1987:SHP-17). 
Men form two rows of three men each, one row facing the other. They bob up and down in dance. Men sing in pairs, with the song being concluded by the naming of a man, his clan lands, and his son. Then the word rauwaraka is sung and the dance positions change. A seed rattle called sorosore is shaken, and axe handles are tapped on the floor (May and Loeweke 1981:227; Chenoweth 2000:180-203). ${ }^{16}$ There are obviously many parallels with the performance of Foi men's sorohabora.

Outside the Foi and Fasu area, there are references to two groups who perform dances said to derive from the Kutubu area. Specific information on other groups in the region is generally lacking, rather than being negative.

In the Bosavi area, the Kaluli perform sabio. ${ }^{17}$ Said to be popular in the Fasu and Foi areas, sabio was taught to the Kaluli by Kutubu carriers in the 1950s, particularly during the construction of the Bosavi airstrip. The Kaluli memorised the songs they were taught. As no new sabio are composed by the Kaluli, the repertoire is completely fixed and stable, and the texts of the songs are unintelligible to them. Sabio is performed in the communal longhouse in the late afternoon or early evening as a prelude to a major all-night ceremony. Sabio songs are sung by two or three pairs of men. The members of the pair face each other and sing alternate lines, coming together on a droned 'oooo'. ${ }^{18}$ No 'bleating' occurs. The next pair does the same until an entire round is completed. Singers bob up and down in place, shaking the sologa seedpod rattle. ${ }^{19}$ Sabio has apparently not been performed ceremonially since 1969 (Feld 1981:1; 1982:35; $1985: 3,6,8 ; 2001: 55 ; 2015) .^{20}$

16 The most detailed descriptions of Fasu namo kesa and a dance called kawari are by Eunice Loeweke and Jean May in Chenoweth (2000:180-203); however, these descriptions are not kept separate from one another, but appear to alternate with each paragraph in their article, often making it challenging to know which performance is being described. I believe I have resolved this problem, but apologise in advance if I have erred. Tone markings on Fasu words, although included in May and Loeweke's Fasu dictionary (1981), have been omitted here.

17 Numerous commercial recordings of sabio have been released by Feld (1981:B2; 1985:B10; 2001:disc 3, nos 17-18).

18 The description here closely follows the Kaluli duet performance of sabio (Feld 2001:disc 3, no. 17). The first two lines sung by a pair consistently only descend to the second-lowest pitch; in subsequent lines, the descent is to the tonal centre (i.e. the lowest pitch). The quartet performance (Feld 2001:disc 3, no. 18) further illustrates these characteristics, but the second pair of performers more immediately echoes each other's lines, rather than singing during the sustained pitches. Such a multipart texture appears to have more similarities with other Kaluli genres.

19 Although the Kaluli sologa rattle (cf. Kasua sogola) is also used in the performance of genres deriving from outside the Kutubu region (e.g. iwo: and heyalo), note the phonetic resemblance of the word to soro ga, the Foi name for the group of paired men who sing sorohabora. See also $\mathrm{n}$. 11 for the relation of this word to the Foi rattle (gasore/gasoro).

20 In the performance of Foi sorohabora, the first singer completes his line of text before the second singer begins his own. Although the Kaluli are imitating a language they do not understand in their performance of sabio, they maintain this distinctive relationship between voices, even though it is quite different from their performance style in all other genres of Kaluli music (Feld 2015), where the second voice more closely follows the first (resulting in a texture more similar to what is found in Foi sago songs sung by two men and female sorohabora). The tempo of sabio is also considerably faster than that of other Kaluli genres. In spite of these 
In Western Province, even further to the west, the Kamula perform sabra, which they also claim originated in the Kutubu area. Here again, between six and 14 dancers form two lines that face each other. Singing is done by pairs of men, one after the other. Songs consist mostly of placenames. Singing may cause some of the audience members to cry (Wood 1982:3, 340, n. 8).

Although descriptions of these dances are by different authors and some information is unavailable, certain features appear to recur among the Foi sorohabora, Fasu namo kesa, Kaluli sabio, and Kamula sabra. In addition to the performance of such dances at night and in the longhouse, these elements include men standing in two parallel rows; men facing their partners as they sing in pairs, alternating lines, but singing together on a final, sustained pitch; men bobbing up and down in dance, shaking seedpod rattles.

Numerous indoor, nocturnal dances in the region also occur, but they are not described as originating from Kutubu. Not surprisingly, the more distant they are from the Kutubu area, the more they seem to deviate from the forms found there (cf. Knauft 1985b:326) - for example, difference in the details of who sings, in what kind of groups, what instruments are used, the focus of poetry, etc. And, the Foi and Fasu also perform other dances than the ones described above that fit this description as well. In the remainder of this section, I will attempt to highlight some of these relationships.

Both the Fasu and Foi perform kawari, which is said to have originated from the Kaluli gisalo and travelled to Kasua speakers and then on to the Fasu and Foi (May and Loeweke 1981:106; Weiner 1988a:22; Chenoweth 2000:180-203). ${ }^{21}$ While the Kaluli have a number of song/dance forms, as discussed below, they claim that only gisalo originated with them. Certain features of gisalo are very similar to the Foi sorohabora and Fasu namo kesa, but differences are also apparent. Distinctively, the Kaluli gisalo uses a sob rattle of bivalve shells suspended on a string (Kasua palo); the rattle is bounced on the floor of the longhouse by the solo male dancer. The all-night gisalo ceremonies are performed by guests for their hosts. The singer attempts to move listeners to tears through the poetic images of loss and abandonment that he constructs while dancing

and other differences, Kaluli still describe the interaction of the paired voices and rattles as dulugu ganalan 'lift-up-over sounding' (ibid.). Further subtleties in the difference between the interaction of the two voices in Foi, Fasu, and Kaluli examples are also evident in the material available, but in all three areas, the sustained tonal centre is at a lower volume, often with a crescendo towards the end. The pronounced 'bleating' in Foi performance appears less pronounced in the available Fasu recordings, and totally absent in Kaluli. Scales between the three groups also appear to be mostly comparable. While these are only preliminary observations, it is obvious that many fruitful stylistic comparisons are worth pursuing.

21 Up until 2013, Kasua groups have performed at three Kundu and Digaso Festivals (2011, 2012, and 2013). In 2013, one of their groups performed gisalo, with other groups performing different dances. Hahudi Farobo, one of the organisers of the festival and someone intimately involved in promoting Foi culture, explained that he has discouraged the performance of such a dance by the Foi (where it is called kawari or agiri) because it is imported from another area (Niles and Gende 2013). 
along the corridor of the longhouse. Initially singing and dancing in place, as he completes the mo: ('trunk' or refrain) section of the song, he moves to the opposite end of the longhouse where he faces the chorus and dances in place again, singing the concluding dun ('branches' or verses) section of the song, while the chorus echoes his singing. At the end of the song, the dancer turns around and performs the entire song again, first singing and dancing alone in place, returning back down the longhouse corridor to face the other chorus, and completing the song with their accompaniment. When overcome with sadness, members of the audience burst into tears and loud wails, grab resin torches, and jam the flames into the dancer's shoulder, resulting in mass whooping from the crowd, along with stamping feet and snapping bow strings, while the dancer continues singing (Feld 2001:58-62; also see, Feld 1982; E. L. Schieffelin 1968).

For the Fasu kawari, however, the kawi aroa rattle used consists of dried crayfish pincers, suspended from a flexible branch, which is inserted in the back of a dancer's belt. The Kaluli degegado (Kasua somasuba) is also such an instrument, but it is used in the performance of iwo:, ko:luba, and ilib kuwo: dances, not gisalo. The Foi of Lake Kutubu (Gurubumena) obtained the costume associated with Kaluli gisalo from the Fasu and refer to the burning of the dancers as siri kebora 'resin burning; scar-making burning'; however, the dance did not travel further east to other Foi (Weiner 1988a:22).

Women may watch the Fasu kawari; the middle partition separating the women's end of the longhouse from the men's is removed, so that the men can dance the full length. Men again sing in pairs, facing their partners. The same phrase of one singer is repeated by his partner. As the texts are borrowed from the Kasua, they are unintelligible to most listeners. Dancers are not burnt, and other participants sit at one end of the longhouse and separately sing sia (Chenoweth 2000:181, 185-86, 202).

The performance of Fasu kawari is preceded by akiri, the playing of roko drums and kawi aroa crayfish-claw rattles by two to four men, but without singing. They stomp up the steps of the longhouse at night, parade down the centre aisle, and sit on the men's side. One man then stands, selects his partner, and the kawari performance begins. The auape keraka drum-beating dance is also performed for healing a sick person (May and Loeweke 1981:10, 22, 106, 202; Chenoweth 2000:186).

A comparable drum dance appears to be the Foi samoga or usanega, performed during the Usane Habora ceremony to cure sickness. Here, two types of $s a^{\prime} o$ drum are used - with a 'fishtail' end ${ }^{22}\left(s a^{\prime} o\right.$ fare) and with a round end ( $s a^{\prime} o$ gauwage or sa'o doibu/duibu) — with a crayfish-claw rattle and without singing

22 Foi call this end sa'o fare gesa, with gesa referring to the fork of a tree or a support pole (Williams 1940-42:149; Rule 1993:99). Also compare the similar nomenclature among the Rumu (Petterson 1999:90). 
(Rule 1993:16, 133; Weiner 1995:101, 112-13). ${ }^{23}$ Williams (1940-42:149; 1977:193-94) suggested that this ceremony arrived from the southeast, perhaps bringing the drum along with it, where previously seedpod rattles would have been used.

Aspects of these performances appear in different combinations throughout the regions to the west and southwest.

The Kaluli gisalo is also reported to have been adopted by the Aemili (Aimele) as gisala, from whom the Kamula long ago borrowed what they call kisama (Crawford 1981:58-59 (Photos 31-34); Wood 1982:3, 329-38). Additionally, the Etoro (Edolo) kosa has relations with the Kaluli gisalo (E. L. Schieffelin 1976:193, n. 4) and the Gebusi (Gobasi) kosaym, ${ }^{24}$ particularly the common usage of a shell rattle bounced on the longhouse floor and similarities between the names, suggest a close relation with the Kaluli form (Knauft 1985a:416, n. 1). ${ }^{25}$ Moving northwards, the Samo kosaman involves male dancers with a rattle of black palm leaves and streamers placed in the dancers' belts. Singing is by men and women (Shaw 1975:231-32). And the Bedamini (Beami) gosei involves male dancers and one or more male choruses; the leader of the chorus sings about recent events, and the chorus repeats each verse. The dancers move back and forth in the middle of the longhouse, and emotional listeners may burn the dancers' backs (Sørum 1980:278; 1982:46). ${ }^{26}$

Drum dances also occur among the Kaluli, where they are called ilib kuwo:; the dance is said to originate from south of Mount Bosavi. ${ }^{27}$ Dancers play $i l i b$

23 Outside, diurnal dance performances with drums by Foi and Fasu performers are now features of the Kundu and Digaso Festival, held annually since 2011. The festivals are supported by Oil Search Limited and other organisations to promote local traditions. Groups from the Mount Bosavi area, Samberigi, Huli, Enga, and Goaribari have also participated (National 2012). While kundu is, of course, the Tok Pisin word for 'drum', digaso and kara'o are Foi words for the tree oil so valued in trade by groups to the north (Rule 1993:89); cf. Fasu tikiaso (May and Loeweke 1981:247).

24 Where names of languages as found in the most recent version of Ethnologue (M. P. Lewis et al. 2013) differ from usage in the ethnographic source being considered, the Ethnologue names are placed in parentheses; hence, 'Etoro' and 'Gebusi' appear in the sources cited, while 'Edolo' and 'Gobasi' are used in Ethnologue. Where no parenthetical additions are found, the names in both sources are the same. I have followed this practice so that the locations of the various groups mentioned can be easily located on the maps found in Ethnologue, a resource freely available on the Internet (http://www.ethnologue.com/).

25 Gebusi (Gobasi) may also burn their dancers, but it is not a prominent part of their performances (Knauft 1985b:335, n. 13). Although he does not name the genre but does mention the singing being performed by women, Knauft (1985b:324-25) appears to compare Kaluli gisalo with Gebusi gigobra (danced by men with drums and crayfish-claw rattles), rather than with Gebusi kosaym (danced by men with a rattle bounced on the floor), even though the latter seems to be more similar to gisalo in some aspects. This illustrates how features differentiating genres in one area may be less distinctive in another.

26 See Niles and Webb (1987:WP-10) for a recording involving the performance of gosei or kosei (two decorated singers sing face to face with sobo bivalve shell rattles struck on the floor; cf. Knauft 1985b:32930), a male chorus (gosege) sitting to the side that responds to the text sung by the main pair, and women separately singing lawine sagorobo hadigibi songs.

27 An origin to the south of Mount Bosavi might lend strength to the Kamula claim for originating such a dance, as discussed later in the main text. 
drums with degegado crayfish-claw rattles, but do not sing, as a prelude to allnight ko:luba, heyalo, or gisalo ceremonies (Feld 1981:1; 2001:55, 62-63). ${ }^{28}$ Kasua irigino drums are played with sogola seedpod rattles (Niles and Gende 2013). The Kamula consider their woiyo 'drum' dance to be their own creation, in contrast to other dances they perform, such as sabra and kisama. It too is performed with a crayfish-claw rattle and without singing (Crawford 1981:59-61 (Photos 35, 38); Wood 1982:224, 317-29). Knauft (1985a:258, 416, n. 1; 2005:68) reports the similar Gebusi (Gobasi) gigobra, performed with $d u o$ drum $^{29}$ and dias moliar crayfish-claw rattle; women separately sing hayay songs to the men's drumming and dancing. ${ }^{30}$ The Samo hobola is a curing dance for which the male dancer plays the duwon drum and inserts a crayfish-claw rattle into his belt. Women sing as the dancer moves around the sick person (Shaw 1975:226, 230-31, 296-304; National Arts School [1986?]). ${ }^{31}$ Finally, the Bedamini (Beami) gafoi or kafoi is performed by a male dancer with an iribu drum. Here the dancer is surrounded by two or three female dancers with rattles (Sørum 1980:278; 1982:46, 51-52). ${ }^{32}$

Albert G. van Beek (pers. comm. (24 Dec 2003), as cited in Craig 2010:191-92) notes the association of kafoi with the final stage of the boys' initiation ceremony (goy lèegi), where an earlier type of drum (shorter, with a 'cubic-formed' distal end) was replaced in the late 1960s with the longer slender one used by the Samo when playing of the former did not have the desired effect following a number of earthquakes and landslides. The distal ends of both types of drums are carved to represent crocodile jaws. A properly tuned drum produces the voice of Awamuni - the cultural hero who gave the Bedamuni (Beami) their cultural identity - calling a-ta 'father-son'. Van Beek also notes the out-ofphase drumming of performers and the similarity of decorations to Kaluli gisalo dancers: 'like the Kaluli know drum performances, the Bedamuni know song performances, but the cultural importance is inverted.'

28 Recordings of Kaluli ilib kuwo: can be found on Feld (1985:B12; 2001:disc 3, no. 6) and Niles and Webb (1987:SHP-14).

29 Knauft (2005:91) reports that Gebusi (Gobasi) males conclude their initiation by dancing with drums for the first time. Kamula males must undergo a certain rite to drum, lest the noise of their playing would scare away game (Wood 1982:247). Further to the west, among Telefol speakers and other Min groups, males in their twenties learn how to drum at the fifth of seven stages of initiation, called wotban. While the drum (wot) itself is not secret, knowledge to play it is learned through ritual, where the relation of the instrument, its playing, and its sound to cultural heroes, taro, death, maggots, decay, and fertility can only be taught through initiation (Brumbaugh 1979:240-41, 368-75; 1990).

30 For a recording of women's hayay singing while men drum, see Knauft (2012). Other recordings from the Nomad area, including the Gebusi (Gobasi) and Kubo can be found on Huguet (1992:tr. 2-3) and a release by Oméga Studio (1981?:B1).

31 During Samo kandila initiation, Shaw (1975:250) reports a rattle of crayfish claws attached to vine or bark string that hits the floor when the dancer bends his knees - apparently a cross between the rattle that is bounced on the floor with one that is put in the back of dancers' belts in other areas. Here the bobbing dance is also taught to initiates as a part of their initiation (Shaw 1975:264; 1982:423).

32 For a recording of kafoi or gafoi, see Niles and Webb (1987:WP-11); a decorated male dancer with ilibu drum and korokiti crayfish-claw rattle perform kafoi while two young girls practise their dance and the singing of siokoi. The performance is to heal the headache of the man seated before them. 
There are even parallels with core Highlands groups. The Huli komia is performed by two drumming dancers, but without singing. It is performed for drought fertility rites (gaiya tege)-perhaps considered another type of sickness - in which the dancers jump over the ali damba cult fence (Goldman 2007:159, Table 9.2). There are obviously many similarities and variations in these traditions over quite a wide area.

In the cases discussed so far, the Kutubu area has been stated as the origin for certain dances or certain dances performed by the Foi or Fasu are said to have origins elsewhere. Aside from these links, however, the inside performance of nocturnal dance ceremonies has much wider distribution.

To the southeast of the Foi, among the Polopa (Folopa), hosts sing and dance in their men's house at night prior to competitive pig-feasting, daring their guests to come and be overwhelmed by their largesse. On the day of the event itself, hosts and guests alternate in dancing in the men's house until the next morning when the bulk of the pork is cooked and given to the guests. Raiding parties also dance, drum, and sing in the men's house at night to taunt their enemies (D. J. J. Brown 1979:714-15, 721). ${ }^{33}$

Among South Kewa- or Erave-speaking groups to the east of the Foi, the rupale dance is performed inside the communal men's house (tapanda) at night, preceding and during pig-kills. ${ }^{34}$ Women and children can enter the men's house at this time. Singing with rattles, men form groups of four to six, ${ }^{35}$ enter the house through the veranda, and trample the floor of the house in unison upon their entrance. Marching along the main central corridor (pukama), they reach the first fireplace and form two rows of two or three abreast. A leader sings a phrase, and the others in the group join afterwards, with the final vowel being a sustained $o$. After 10 seconds of silence, there is a single repetition

\footnotetext{
33 Nocturnal indoor dance performances appear to be absent among the Daribi (Dadibi), to the east of the Polopa (Folopa). Dances performed during Wagner's fieldwork there were said to have origins to the east (Gimi), northeast (Gumine (Golin)), or west (Bąria (Wiru, East Kewa, or Foraba (Folopa))) reaching the Daribi in the mid-1930s (Wagner 1967:6-7; 1972:80-84, 164-65). While the Angan Baruya further to the east sing daata inside initiates' houses, there is no dance.

34 The following description is taken from LeRoy's work in Koiari; other descriptions of performances of rupale (or tupale) are given by Josephides (1982:45-46, 79-84) and MacDonald (1991:100-102), who worked primarily in Aka and Mararoko, respectively - all part of the Erave language area. Noteworthy differences from LeRoy's description are included here in footnotes. A recording of rupale is presented by Niles and Webb (1987:SHP-7), where the singing is accompanied by sekeseke rattles - dried seeds enclosed in a sewn, rectangular pandanus covering.

35 Josephides (1982:46) also notes men carrying axes and that there are four men in a group; MacDonald (1991:100-101) agrees and says men strike usaane drums as well, and observes that rupale may also be performed outdoors, in which case four or six men stand abreast. Note that the name of the drum here is very similar to the name of the Usane Habora ceremony the Foi perform to cure sickness, perhaps lending credence to Williams's claim that the Foi ceremony arrived with the drum from the southeast (1940-42:149; 1977:193-94).
} 
of the same note. ${ }^{36}$ The same song is then repeated with some variations, a second song follows, and it is also repeated. The group then marches to the second pair of fireplaces and sings the same songs there; their place at the first fireplace is taken by a second group, and then a third, etc. When a group has sung at all the fireplaces, it exits the house through the back, prepares two new songs, and enters again through the front to sing at the first fireplace again. This simultaneous singing of songs by different groups, movement between fireplaces, and the entry/exit of groups continues throughout the night (LeRoy 1978:53-54, 70, n. 2). Full decorations for such a performance are called kewa au, 'decorations of the southerners' (Josephides 1982:45), perhaps a reference to the similarities of such performances with fringe groups to the south.

For the West Kewa, Franklin (1978:389) notes the performance of songs in memory of the dead with a shuffling dance back and forth along the inside corridor of men's house. And LeRoy (1985:95) reports that West Kewa yasa, like Erave rupale, takes place at night so that ghosts can hear them; in both regions, songs contain messages to the dead and the living.

Now moving to the west of the Foi and Fasu, nocturnal longhouse performances are reported for the Kasua, Kaluli, and Etoro (Edolo), as noted above. In addition to the gisalo, sabio, and ilib kuwo: discussed above, Kaluli also perform iwo:, heyalo:, and ko:luba, all of which were adopted from groups ranging from the southeast to southwest of Mount Bosavi (Feld 1981:1; 1982:35; 1985:3-8; 2001:55, 63-67; B. B. Schieffelin and Feld 1998:72, 89; E. L. Schieffelin 1976:225-29). ${ }^{37}$

Across the border with Western Province, indoor, night-time performances are reported among the Bedamini (Beami) gosei; Gebusi (Gobasi) kosaym; and Samo kosaman, as reported above; Awin (Aekyom) sia (Depew 1983:5-10); ${ }^{38}$ Yonggom kibirat, yok, urumanop, ame'op, wod, ondan, and aip (Kirsch 1987:2-3); ${ }^{39}$ Kauwol (Faiwol) yoron vinum; ${ }^{40}$ Ngalum oksang; ${ }^{41}$ and the Kamula sabra, as described above.

\footnotetext{
36 The Koiari villagers with whom LeRoy worked claimed this repetition was their innovation (LeRoy 1978:54).

37 For recordings of Kaluli ceremonial genres, see Feld (1981:B1-3; 1985:B8, 10; 2001:disc 3) and Niles and Webb (1987:SHP-13-14, 16).

38 See Niles and Webb (1987:WP-8) for a recording involving men in two groups, with kosiai rattles of seeds suspended from a cane frame in the back of their bark belts, their group singing and dancing punctuated with solo dancing and drumming. Women sit at the side.

39 See Niles and Webb (1987:WP-12) for a recording of a kibirat performance to determine the identity of the person who has caused an illness.

40 See Niles and Webb (1987:WP-13) for a recording involving dancing in a twisting line inside the house, with men singing in alternation with the snapping of bowstrings and fotfot whistling, made on inhalation.

41 Abmisibil, Bonai (both Ngalum), and Okbap (Ketengban) dance houses have springy floors and belong to several village communities (Simon 1993:170-71, CD 6, It. 1-3). See Niles and Webb (1987:WP-18) for a recording of amsang, performed by men singing and dancing while holding at their backs yaso rattles made of fronds from the bot tree. This recording was made of a visiting group. While they appear to have been Ngalum speakers, this identification is not definite.
} 
Further south in Western Province, ceremonial nocturnal performances still occur in some longhouses, but they seem to be increasingly concerned with initiation, the presentation of secret knowledge, etc. This appears to be true for dances such as those presently or formerly found among the Gogodala (Crawford 1981:176, 253-56, 274-83) (2) $^{2}$ and Kiwai (Southern Kiwai), such as, wete, madia, maure moguru, ganu, baiduo, mado, gama mutu, barari, upipoo, asasi, etc., performed in the darimo 'men's house' or moto 'communal houses', often involving drumming men in two rows, with women, boys, and girls singing, but some of these dances may also be performed outside and during the day (Beaver 1920:180; Riley 1925:40-44, 47; Landtman 1927:351, 408-20).

This trend seems to continue eastwards into Gulf Province. For example, among Morigi speakers on the western banks of the Turama River, dances were associated with headhunting and the display of skulls on agibe boards in the longhouse. Mipa and barari are performed nocturnally, but there are also indoor diurnal performances. Paired dancers are led by warriors with drums, their wives, then bachelors who can carry drums but have not passed a certain stage of initiation, then bachelors who have not killed a bush pig and consequently cannot play drums, with the lines ending with warriors and their wives again (Austen 1936). Among Kerewo speakers to the east, similar indoor dances called gibumamu are performed with drums (Austen 1934).

From at least the Koriki (Purari) and further eastwards, communal longhouses were absent, but men's longhouses existed. However, most performances did not appear to take place inside these longhouses; instead, masked dancers dramatically emerged from them during the day. For the Koriki (Purari), masked gopi dancers were accompanied by singing and drumming from men seated at the front of the ravi longhouse (Williams 1924:171, 173). Among the Orokolo, the masked hevehe dancers themselves played drums. While women were not allowed into the longhouses, upon emergence from the longhouse, each masked dancer was met by its own group of adoring females who danced with it in the village plaza and down to the beach over a period of a month. Such ceremonial cycles took between one and three decades to complete. Similar forms appeared among groups further to the east as well (Williams 1939:145, 152-55; 1940:35758; Welsch 2006:11-12, 23).

Such similarities with groups to the south, but also involving significant contrasts, are perhaps to be expected as groups such as the Foi are 'culturally coastal peoples who have moved north and have settled in the southern fringe of the New Guinea Central Highlands' (Weiner 1988b:3). Andrew Strathern also writes of 'longhouse culture' moving from the south to the north (1988:196).

42 See Niles and Webb (1987:WP-6) for a recording in which the singing and dancing is accompanied by striking the distal end of the sololo split-bamboo rattle against the longhouse floor during aida initiation. 
While the affinities with groups to the south are clear, indoor dances, sometimes at night, are also reported for some groups on the northern fringe of the Highlands, such as the Kalam smiy where men sing inside and reveal esoteric knowledge to initiates, while women beat drums and dance around the house (Bulmer 1967:13; Grove 1978:17), Hewa yap mofau performed in a new house before the inhabitants move in (Steadman 1971:55, 76, 108-10), and Awiakay kaunjambi all-night performances of spirits singing through male performers (Hoenigman in prep.). ${ }^{43}$ While performances take place inside some Sepik spirit houses, these often represent or create the voice of spirits, frequently using instruments; such performances can be heard, but not seen, by the uninitiated, and are associated with the presentation of secret knowledge, initiation, and aspects of male ceremonial life - see, for example, descriptions for the Iatmul (Wassmann 1991; Spearritt and Wassmann 1996), Ambonwari (Tabriak) (Telban 1998; 2008), and Waxei (Watakataui) (Yamada 1997).

Across the border and into the Indonesian province of Papua, the Eipomek appear to only perform outside, but the Kapauku (Ekagi) construct an ema dance house during pig festivals when nocturnal dancing takes place (Pospisil 1963:72-76). Among the Konda Valley Dani (Western Dani), courting parties take place that somewhat resemble the nocturnal indoor activities in parts of the Papua New Guinea Highlands, but it seems that song and dance are absent (O'Brien 1969a:212, 349-50, 383-85; 1969b:212). Hence, while indoor performances may be found, many aspects of their performance are quite different from my concern here.

After this consideration of some of the distinctive aspects of the performance of Foi ceremonial dance and song and its relation to other groups in the region, I turn now to a focus on the collection itself and the texts it contains.

A collection of song texts in the original language and in translation is significant in itself. While spoken stories are often published in translation and rarely in the original language (except in specialised linguistic studies), vernacular song texts and their translations are frequent components of many ethnographic studies. This suggests that there is something special about these texts. Songs are sung poetry, that is, their texts are in a language that is somehow different from normal speech. For a knowledgeable listener, these texts also tend to encapsulate important aspects of culture. Here I am interested in what makes sung language different from normal speech.

43 Awiakay speakers number about 300 and live in Kanjimei village, East Sepik Province. Although presently not included in Ethnologue (M. P. Lewis et al. 2013), their language belongs to the Arafundi group (Hoenigman in prep.). 
In the following sections I consider two features of this volume that are of relevance to more general studies of Papua New Guinea song. ${ }^{44}$

\title{
Collections of song texts for sociocultural revelations
}

\author{
Researchers frequently discuss song texts as part of more general ethnographic \\ accounts. Indeed, it would seem that most Papua New Guinea ethnographies \\ contain at least a few song texts. While publications focused on music would \\ naturally be assumed to make use of such texts - such as Stella's monograph on \\ the Banoni (Bannoni) (1990) and Feld's on the Kaluli (1982) — songs are actually \\ cited in a much wider range of works.
}

Song texts often encapsulate or provide insights into various sociocultural concerns, such as Fortune's frequent use of Dobu songs throughout the main text of his book and in an appendix (1932). Or the publications may consider

44 For the following discussion of poetry, I consulted about 150 articles, theses, and books in the Music Archive of the Institute of Papua New Guinea Studies. While not exhaustive, and generally omitting sources consisting solely of texts and translations without significant commentary (e.g. Brash and Krauth 1973; Helfert and Holdsworth 1974), the sources below cover a good range of materials and serve as an introduction to this subject. In order to keep the main text here as uncluttered as possible, I have avoided detailed referencing except where discussing specific issues in more detail. Apart from a few initial sources of general discussion, the groups and the references I have consulted are listed here under the conventional four geopolitical regions of Papua New Guinea: General discussion (Niles 2011b; Niles and Rumsey 2011; Webb and Niles 1990); Highlands region: Baruya (Niles and Webb 1987:EHP-8); Benabena (Young 1968); Daribi (Dadibi) (Wagner 1972); Duna (Gillespie 2010; Gillespie and San Roque 2011; Kendoli 2011; Niles and Rumsey 2011; Sollis 2010; 2011; A. Strathern and Stewart 2011); Enga (Talyaga 1973; 1974; 1975; Gibbs 2001; 2011; Niles and Rumsey 2011); Erave (LeRoy 1978; Josephides 1982); Golin (Donohoe 1987); Huli (Pugh-Kitingan 1981; Lomas 2011); Ialibu (Imbongu) (Kerema 1976?); Ipili (Ingemann 1968; 2011; Borchard and Gibbs 2011); Kalam (Pawley and Bulmer 2011); Kaluli (E. L. Schieffelin 1976; Feld 1978; 1982; 1985; 1990; 2001); Karinj (Angal Heneng) (Reithofer 2011); Ku Waru (Bo-Ung) (Rumsey 2001; 2007; 2011; Niles 2007; 2011a; Niles and Rumsey 2011); Kuman (Whiteman 1965; Bergmann 1971; Gende 1998); Kyaka (Koyati 1979); Melpa (A. Strathern 1974; G. Strathern and Strathern 1985; A. Strathern and Stewart 2005; 2011; Niles 2007; 2011a; 2011b; Niles and Rumsey 2011); North Wahgi (Luzbetak 1954); Usarufa (Chenoweth 1979); Wahgi (Jimben 1984); West Kewa (Franklin 1970; 1978); Wiru (Paia and Strathern 1977); Momase region: Alamblak (Coulter 2007); Awiakay (Hoenigman in prep.); Boiken (Boikin) (Niles 2000); Central Buang (Mapos Buang) (Hooley 1987; Chenoweth and Hooley 2010); Gnau (G. Lewis 1980); Iatmul (Bateson 1932; Wassmann 1982; 1988; 1991); Irumu (TumaIrumu) (Kelsey 1993); Jabêm or Yabim (Yabem) (Pöch 1905; Zahn 1996); Kairiru (Niles 2000); Karesau (Kairiru) (Schmidt 1909); Karawari (Tabriak) (Telban 2008); Manambu (Harrison 1982; 1986; Aikhenvald 2014); Mapos Buang (Sankoff 1977); Maring (Rappaport 1968); Monumbo (Pöch 1905; Vormann 1911; Graf 1950; Niles 2000); Nekgini (Reigle 1995; 2001); Sissano (Niles 2000); Tifal (Roberts 1996; 2014); Tumleo (Niles 2000); various parts of Morobe province (Neuhauss 1911); Waxei (Watakataui) (Yamada 1997); Wovan (Haruai) (Flanagan 1983); Southern region: Binandere (Waiko 1984; 1991; 1995; 1982); Bwaidoga (Bwaidoka) (Jenness and Ballantyne 1926-29; 1928); Dobu (Fortune 1932); Gebusi (Gobasi) (Knauft 1985a; 1985b); Gizra (Gizrra) (Laba et al. 1980); Keraki (Nambo) (Williams 1936); Kilivila (Baldwin 1945; 1950; Kasaipwalova 1978; Kasaipwalova and Beier 1978a; 1978b; 1979; Senft 1999; 2011); Kiwai (Southern Kiwai) (Landtman 1913; 1927); Koita (Koitabu) (Niles 2000); Korafe (Korafe-Yegha) (James 1978); Koriki (Purari) (Williams 1924); Motu (Barton 1910); Okena (KorafeYegha or Ewage-Notu) (Niles 2000); Orokolo (Williams 1940); Suau (Cooper 1975); Toaripi (H. A. Brown 1968); Wagawaga (Seligman 1910); Islands region: Akara (Lele) (Laba et al. 1980); Baining (Qaqet) (Aerts and Hesse 1979; Fajans 1985); Banoni (Bannoni) (Stella 1990); Buin (Terei) (Thurnwald 1912; 1936; 1941; Laycock 1969a; 1969b; 1969c; 1970; 1972; Oliver-Berg 1979); Kaulong (Goodale 1995; Drüppel 2009; Niles 2009); Lak (Siar-Lak) (Wolffram 2007); Mandak (Madak) (Clay 1986); Takū (Takuu) (Moyle 2007); Tolai (Kuanua) (Laba et al. 1980); Western New Guinea: Central Asmat (Voorhoeve 1977); Eipomek (Simon 1978; Heeschen 1990; Simon 1993). 
some aspect particularly well presented through song texts. Publications in which song texts are a major focus include studies by Baldwin (1945; 1950) and Senft (2011) on the language and interpretation of Kilivila songs; Ingemann (1968) on the structure of Ipili courting songs; Franklin (1970) and LeRoy (1978) on the metaphors used in West Kewa and Erave song, respectively; Hooley (1987) on the poetic transformations of Central Buang (Mapos Buang) song texts; Wassmann's detailed consideration of Iatmul mythopoetic ceremonial songs (1982; 1988; 1991); and Rumsey's explorations of Ku Waru (Bo-Ung) sung tales, tom yaya kange $(2001 ; 2005 ; 2007 ; 2010 ; 2011)$, a form having characteristics of both songs and storytelling.

Weiner's exploration of the texts presented in this volume was published separately as The Empty Place (1991). As such, it straddles the category mentioned above along with publications that appear to be primarily meant as simply collections of song texts, usually appearing in the original language and in translation. Notes in such collections comment on various aspects of the songs presented, such as performance contexts, dance movements, origins, poetry, performance style, etc. ${ }^{45}$ Such collections, often consisting of dozens of songs, are well represented for the following languages, moving out from the Foi area (collections containing more than 100 songs are noted): Enga (Talyaga 1973; 1975; Gibbs 2001); Ialibu (Imbongu) (Kerema 1976?); Kyaka (Koyati 1979), containing 123 songs; Kewa (Erave) (Josephides 1982); Wiru (Paia and Strathern 1977); Melpa (A. Strathern 1974; G. Strathern and Strathern 1985); Tifal (Roberts 1996; 2014), with 200 songs and music transcriptions; Kilivila (Kasaipwalova 1978; Kasaipwalova and Beier 1978a; 1978b; 1979); Bwaidoga (Bwaidoka) (Jenness and Ballantyne 1926-29; 1928), containing 144 songs and incantations; and Buin (Terei) (Thurnwald 1912), with 130 songs. Perhaps most similar to Weiner's volumes is the consideration of Manambu love songs by Harrison (1982; 1986): 21 song texts, translations, and summaries are preceded by a lengthy consideration of the genre, its structure, and the circumstances of its performance.

As such, Weiner's work on Foi songs well complements the work of others in exploring the importance of sung texts to ethnography in Papua New Guinea.

45 Michael Webb and I have published a collection of traditional song texts and translations, accompanied by cassettes of the songs, which is meant to be used in schools, Ol Singsing bilong Ples (Webb and Niles 1990). Although not the focus of my introduction, a comparable collection of stringband songs, meant to be used by people wanting to learn to play guitar, is Riwain! Papua New Guinea Pop Songs (Webb and Niles 1986). A collection of transcriptions and translations of Akara (Lele), Tolai (Kuanua), and Gizra (Gizrra) texts from Institute of Papua New Guinea Studies recordings is found in Laba et al. (1980). 


\section{Poetic devices of song}

Weiner's discussion of the poetic language used in Foi songs is scattered throughout The Empty Place. He considers various devices that are used in Foi sung performances that distinguish those texts from everyday language; hence, he is concerned with the poetic expression found in Foi songs. These devices include parallelism, metaphor, poetic vocabulary, the construction of a map based upon the places mentioned in a song, phonological features reflecting motion and space, and 'hidden' names used to identify the subject of a song.

While a detailed consideration of Papua New Guinea song poetry is not appropriate here, the following overview of some of the poetic devices used is meant to assist readers interested in understanding how the Foi examples relate to other groups in the country. For what is probably the most detailed consideration of the song poetry of any one group, see Feld's writings on the Kaluli (especially, Feld 1982:130-62).

\section{Poetic language}

In almost every source that discusses Papua New Guinea song texts, mention is made of the use of poetic language, either in reference to individual words or longer parts of the text. These might be words from specialised or less familiar vocabulary; ${ }^{46}$ an archaic version of the present language; another dialect or language (perhaps, thereby, suggesting origin, trade, purchase, or prestige); the language of spirits or ghosts; or newly created words as the result of word taboos. Sometimes such poetic usage can be readily understood, but more often it appears to challenge and entice listeners.

This usage differs from that described in the following section for vocables in that the latter are not suggested to be from another language, but simply to fill out a line, hence they often fulfil a formal, musical function; there is no consideration of them having meaning aside from a functional one. Certain vocables might be associated with specific genres, but they are generally regarded as filler, necessary to complete a song, but not endowed with any other meaning.

Foi use poetic designations to reference villages (Weiner 1991:162), and the use of the 'hidden name' used to identify the subject in the dawa of sorohabora could also be considered poetic language. ${ }^{47}$ Additionally, Duna poetry makes

\footnotetext{
46 Metaphorical meanings of everyday words are not considered here, but in the following section concerning modifications.

47 Weiner (1991:19-20) contrasts spells and songs. A spell's efficacy is related to its rote memorisation and recital, with the words often in esoteric language; whereas a song is always an individual composition in generally accessible language, attempting to rend an emotion or interior state in terms of a concrete object or sensual experience. Furthermore, the song evokes, but the spell does not. While the song produces direct emotional response, the spell seeks pragmatic transformation.
} 
extensive use of kẽiyaka, glossed by researchers as 'praise names', special poetic terms that are used in pikono sung tales, often resulting in parallelism (see below) (Gillespie and San Roque 2011), and the Central Asmat use arcer (everyday speech) and ta-poman (poetic word or metaphor) in songs, with some of the latter terms coming from inland areas, but the origins of most are unknown (Voorhoeve 1977). What may be untranslatable to one researcher at one moment in time, may prove decipherable by someone else later, such as the Iatmul texts Bateson thought were in a shaman's language subsequently being clarified through the diligent, meticulous research of Wassmann (Bateson 1932:403-4, 407; Wassmann 1991:63-64, 230). While there are many statements by researchers that an archaic form of language is being used, it does not appear that historical linguists have attempted to validate such claims. In their songs, Trobriand Islanders use a variety of Kilivila language they call biga baloma 'speech of the spirits of the dead' or biga tommwaya 'old peoples' speech'. They are convinced that it is language of the spirits of the dead in the Tuma underworld and that it is an archaic variety of Kilivila; only a few elders still know the meanings of such songs (Senft 2011:43-48).

Modifications to sung texts in the learning process also bring about changes to song texts, particularly when the learners are not fluent in the original language of the song. Gunnar Landtman relates how Southern Kiwai speakers imitated a song they heard at Budji, an Agob-speaking village, eventually quite distorting the original text:

they simply copy the dances and words, but, in spite of their natural cleverness in mimicry, both tunes and words must get more or less changed, still more so the interpretation which they may give to the songs. (Landtman 1927:423)

Neuhauss (1911:388) makes a similar observation about how the words of a song change when performers do not know the language they are singing in. Although specifically mentioning the Ka-iwa (Iwal) of Morobe province, he intends his remarks to be relevant over a much wider area. Indeed, writers had been noting the unintelligibility of song texts to their singers in the Morobe and Madang area for over two decades (e.g. Schmidt-Ernsthausen 1890:232; Pöch 1905).

Manambu namai love songs consist of two nearly identical stanzas (apak), the first in Manambu, the second in the western dialect of Iatmul, a language the singers are fluent in (Harrison 1982:18). ${ }^{48}$ Kaluli gisalo makes extensive use of words,

48 According to Aikhenvald (2014), Manambu women refer to the second verse of their namay as using wording considered the 'shadowy' register or 'the other side' (agakem 'on the (other) side of two'). While many of these words in the 'shadowy' register derive from Iatmul, others may derive from Manambu itself as antonyms or more generalised terms being used for specific ones. 
lines, or whole texts from the Sonia language to their west (E. L. Schieffelin 1976:178; Feld 1982:139-42, 152). In all areas, while the use of such language appears to make the texts more poetic, listeners differ in their ability to understand them. Even though the words of a song may not be completely understood, listeners are often adept at trying to interpret them anyway.

For the Gnau, song words are thought to be from ancestors, and the general sense of each verse is known, but words often differ from what is used now. For example, the word simarei in song is translated as 'it flares', but in everyday language the word marara' $a$ has such a meaning. While the words are said to be archaic, song verses can be interpreted because words resemble those in neighbouring languages or even in Tok Pisin, and the names of places and persons are recognisable, but often distorted through much syllable repetition and drawing out (G. Lewis 1980:41, n. 1, 59). A fascinating discussion of such meanings and how they relate to the important question of the order of performance of around 150 songs in a Gnau song cycle is also presented by Gilbert Lewis (ibid.:60-61).

As songs are sung in unison by a group of performers in many regions, songs must be learned by the group, regardless of their intelligibility. Yet even if the meaning of the text remains generally unknown to performers, the numerous rehearsals and performances of such songs generate other meanings among the individuals who perform and who observe. Among the Lak (Siar-Lak) of southern New Ireland, this feeling is intensified as a result of the long periods of fasting and isolation necessary for performance, hence the 'opening lines of [such] a song are responded to by a barrage of weeping from the audience as they recall poignant associations generated by narratively "meaningless" lyrics' (Wolffram 2007:185).

Awiakay kaunjambi texts contain parts identifiable as everyday Awiakay, an untranslatable 'spirit language', neighbouring languages (some related to Awiakay, others not), and archaic language (Hoenigman in prep.).

The Gebusi (Gobasi) like the songs of their Bedamini (Beami) neighbours, although few Gebusi are fluent enough in that language to understand the poetry of songs. Rather, Gebusi react to the 'visual and raw auditory sensation of Bedamini performance, rather than to its discursive meaning' (Knauft 1985b:329).

\section{Vocables}

A distinction was made in the preceding discussion between a song entirely of or containing words in a poetic or unknown language, on the one hand, and the use of vocables or 'nonsense syllables', on the other. The former might be described by performers as being in an archaic or different language, but the 
latter is often described as syllables added to fill out a melody. These vocables typically appear at the end of lines of sung text as lengthened or added vowels. More lengthy sequences of vocables may be used to fill in a text that does not fully accommodate a melody or as an entire section of the song, and may often be called a 'chorus' or 'refrain' by the author writing about them. Such vocables are particularly important where a repetitive metric system is important, such as in the Mount Hagen area. Vocables may also completely replace the 'meaningful' text in statements of the melody. In many of these uses, they are an essential structural component of song.

Lengthened or added vowels at the end of a line of text are found in many different parts of the country. Although frequently associated with the Highlands area, entire lines or verses of vocables are also found in areas as diverse as Jabêm (Yabem), Irumu (Tuma-Irumu), Gnau, Alamblak, Central Buang (Mapos Buang), Kaulong, and Akara (Lele). For example, Drüppel notes how in Kaulong songs, 'strings of lexically-meaningful words are interrupted by strings of vocables. These too are learned and are an integral, non-interchangeable part of the song' (2009:124). Chenoweth observes that Usarufa vocables 'beautify the words of a song' (1979:90). Baruya daata ${ }^{49}$ consist of three sections: daimaata (vocables sung to establish the melody, repeated an indefinite number of times), daluya (addition of text to melody, repeated an indefinite number of times), and daimaata (as before, but sung only once to conclude the song).

What is then striking about the Foi texts presented here is the relative absence of such non-lexical syllables-Foi song texts appear to be predominantly in the language of everyday discourse. Other comparable examples are not so commonly reported, although Fortune stresses the absence of 'meaningless word[s]' in Dobu songs (1932:255). And, as in the Iatmul case cited above, but also true for Central Asmat songs (Voorhoeve 1977:27, n. 26), seemingly incomprehensible songs might actually be translatable.

Yet the contrast between texts of vocables and of other languages is not quite so easily maintained as it can sometimes be difficult to differentiate the two. Generally, melodies sung to vowels with few consonants unequivocally tend to be vocables, but it is also possible to imagine words sung in a language not understood by the performers gradually becoming distorted (as in the Landtman story above), so that a text in a different language finally becomes vocables. And certainly 'nonsense' syllables sung during the sixth and final stage of Wovan (Haruai) initiation (aime) are loaded with meaning for participants and onlookers alike (Flanagan 1983:217). 


\section{Repetition}

Although not often identified, songs frequently involve strict repetition of words, phrases, or lines. Additionally, of course, whole songs are often repeated in the course of the same or different performances. As this deviates from normal speech, I also consider it a poetic device. Repetition has been reported from such widely separated groups as Enga, Wiru, Benabena, Southern Kiwai, Central Buang (Mapos Bunag), and Baining (Qaqet).

\section{Parallelism}

In my usage here, parallelism is related to repetition, but instead of being a strict repetition, it involves change. Rumsey $(1995: 108 ; 2007: 261)$ describes parallelism as 'the ordered interplay of repetition and variation'; it is a very common poetic feature found in all regions of Papua New Guinea (Niles 2011b:70-72, 413-14, 496-97; Niles and Rumsey 2011:13, n. 9) and throughout the world (Jakobson 1960; Fox 1977). For Papua New Guinea song texts, parallelism (also called substitution), most frequently involves the change of one or more words in the repetition of a line or lines. For example, in the opening of a Iatmul song where pairs of totemic names are sung:

- $m$ kan wana nyan-a $-i-e$

kumbui Kumbuindemineli- $a-l a-i-e,-e-e$

kan wuna mbaandi-a-i-e

kumbui Kwalimbangimeli- $-i-e,-e-e$

You my child,

you flying fox Kumbuindemineli;

you my novice,

you flying fox Kwalimbangimeli. (Wassmann 1991:3-4)

Comparable mythic references are also found among Manambu namai in what purport to be the more mundane songs of failed relationships (Harrison $1982 ; 1986)$.

Foi songs use parallelism extensively, as can be seen in looking at the song texts in this volume. ${ }^{50}$ For example, in this excerpt of lexical and semantic parallelism from men's song 38:

nomo ira fiwa dera

forabi'ae

nomo ira furabo dera

foramaibi'ae

50 Also note the semantic parallelism of Foi magic spells (Weiner 1991:16-17) and Ambonwari (Tabriak) songs (Telban 2008:227). 
nomo kosa'a buru ga merabe

kigiboba'a

nomo ira furubu ga merabe

aodoboba'a

My fiwa tree there

Has fallen by itself

My furabo tree there

Has fallen down

My harbour near the base of the kosa'a buru tree

The forest has reclaimed it

My harbour near the base of the furubu tree

The bush has obliterated it

Some of the most extensive uses of parallelism are found in Kaulong songs of West New Britain where the initial 'chorus listing' of a song enumerates names or objects having the lowest level of appreciation; each repeat of a line substitutes a different name or object, ending with that most highly regarded (Drüppel 2009:126; also see, Niles 2009:xvii-xviii). As described above, the Duna use of kẽiyaka also results in parallelism, as does Central Asmat use of arcer and tapoman.

Grammatical parallelism has also been described by Rumsey for Ku Waru (BoUng) tom yaya kange performances. Here, distinctive grammatical structures, not words, are repeated in subsequent lines (Rumsey 2007:263-64).

\section{Modification}

Song texts may also be modified versions of normal spoken language. Such modifications can be phonological, grammatical, or semantic.

At a phonological level, vowels or consonants may be altered from their everyday values. As noted by Telban (2008:219) for the Ambonwari (Tabriak), but certainly very widely applicable, the words of a song may be 'merely indicated and not fully articulated', thereby setting them apart from everyday language and adding to their esoteric nature. That is, sounds are altered simply through singing. Chenoweth (1979:97) notes the 'broader phonetic range in singing than in speaking' for Usarufa. In Takū (Takuu) songs, an $a$ often changes to $o$, so that vaka 'canoe' becomes voko, and ava 'channel' becomes ovo (Moyle 2007:174). In Central Asmat songs, voiceless consonants become voiced, and some stops become fricatives ( $\mathrm{p}>\beta ; \mathrm{k}>\gamma$ ) (Voorhoeve 1977:35, n. 7). Laycock (1969c) notes the use of archaic morphology in Buin (Terei) songs. 
Vowels are often lengthened or added to the final word, thereby overlapping with the vocables discussed above. But syllables may also be added mid-word, such as in Central Buang (Mapos Buang) modifications verup > veröörup 'come up' (Hooley 1987:76).

Some of the most elaborate word transformations have been described for Buin (Terei) songs (Laycock 1969c:6-13), where two syllables are added to the first or last two syllables of a normal word, creating a form suitable for songs; or the two syllables from a normal word might be reduplicated. For example: kugunia $>$ niakoto 'Venus'; maikuna > kunapiy 'dog'; kamuai > kamukamu 'man's name'. Other transformations are also possible. Brown (1968:iii) remarks how words can be divided between musical phrases, and Roberts $(1996 ; 2014)$ notes the alteration of words to fit melodies.

Phonemes, syllables, or words can also be deleted, all contributing to the 'telegraphic brevity' of Daribi (Dadibi) baria dance songs and laments (Wagner 1972:80), an apt description also applicable to many other traditions.

The deletion of words, of course, overlaps with modifications at the grammatical level. The texts of West Kewa songs, for example, have shortened verbs, with many tenses and aspects deleted, thereby making the actor obscure and possibly obliterating subject, location, and goal markers (Franklin 1978:392). Rumsey (2007:261) observes the use of shorter syntactic units in Ku Waru (Bo-Ung) sung tales. Often, however, written descriptions of grammatical modifications are less precise, with authors noting an unspecific type of poetic grammar or grammatical changes.

Semantic modification concerns words taking on new meanings or interpretations. Such use of metaphors in song texts is used by the Foi (e.g. Weiner 1988a:126; $1991: 19,28 ; 1998 a)$ and is widely reported for Papua New Guinea. As LeRoy (1978:71, n. 6) stresses, a metaphorical language is not a different one, but is constructed from everyday language. Understanding such meanings is often challenging to listeners who lack special knowledge about poetic usage. ${ }^{51}$ Furthermore, in those areas requiring initiation to different types of knowledge, secret subjects may also be sung about publicly, hidden by metaphors that make their meaning inaccessible to those without the requisite knowledge.

\section{Sound-play}

By 'sound-play' I refer to various ways the sounds of words are combined in song texts. Examples of the general similarity between the vowels of words

51 Weiner (1991:28) contrasts the images in poetry with those in dream interpretation. While the latter are standardised, poetic images are individually created, so their interpretation is dependent upon the knowledge of the creating poet. 
(assonance) or consonants of words (consonance; with alliteration being a subtype) are occasionally noted, but not frequently. For example, the pairing of words such as eklka / maklka, röngim / röngan, rarla / marla, nginoü̈ / minoü̈, and ekita / ronggeta in Melpa songs (A. Strathern and Stewart 2005:208-9). The Foi use of phonological features reflecting motion and space might also be included here (Weiner 1991:80-87).

Rhyme - similar sounds at the end of words or lines - while used occasionally in obedobora and sorohabora, is generally rare in Foi song (Weiner 1991:134, 170). This also seems to be true for most other groups in Papua New Guinea, with few exceptions.

What can be considered another type of sound-play, onomatopoeia or phonaesthesia, is an important aspect of Kaluli song composition, as reported by Feld (1978:15-16; 1982:144-50).

\section{Mapping}

Finally, the mapping of places mentioned in a song is of great importance for the Foi (Weiner 1998a:105-6) and the Kaluli (Feld 1978:15-16; 1982:150-56), but also for groups such as the Gnau (G. Lewis 1980:59-67). Weiner observes that 'Mountain Papuan' peoples, such as the Kaluli and Foi, poetically depict genealogical relationships as spatial ones between place names (1988b:23). Ayamo place names figure prominently in Foi songs as they evoke pleasant memories of hunting during the wet season. Yet as they are removed from the Mubi Valley, they are also associated with death (Weiner 1991:114). Kaluli songs map out lands, waters, and trees of significance to their hosts. These images of loss and abandonment move them to tears and they burn with a torch the dancer responsible for evoking their grief (Feld 1985:3).

In contrast, the place names in Gebusi (Gobasi) songs are rarely of the hosts' lands, rather they are of distant places felt to be ideal for secret encounters and sexual trysts. Gebusi respond to these songs sung by women not with weeping and burning, but with

an enthusiastic and bawdy expression of sexual vitality. Hosts and visitors joke hilariously, fantasizing how they will bring to fruition the sexual scenario evoked by the beautiful dancer and the women's seductive songs. (Knauft 1985b:325)

While this overview of poetic devices has been very brief and deserves to be fleshed out elsewhere, it describes some of the ways in which texts become sung poetry for the Foi and other groups in Papua New Guinea. 


\section{Closing and acknowledgements}

I hope that these introductory remarks will be of assistance to someone wanting to understand more about the Foi songs presented in this volume. In particular, I have tried to bring together some details about the contexts of their performance, their relation to other genres in the region, the importance of song texts to anthropological studies, and the poetry of song in the Papua New Guinea area.

I also hope that this book, in combination with other writings by Weiner, will help reveal the importance of understanding Foi traditional modes of expression. As contemporary Papua New Guinea faces many challenges and some people feel that traditional beliefs hinder the nation on the path towards development, this study strongly reconfirms the importance of understanding such creativity. This book celebrates Foi traditional knowledge and the wonderful, full, and complex world that is revealed in song.

James Weiner sent me an initial draft of his manuscript in 1995. I was initially enthusiastic about its possible publication, but suggested he expand the introduction to more widely consider song traditions in the country. In retrospect, I realise that that was probably a rather scary, off-putting response, no doubt contributing to the manuscript lying dormant for a long stretch of time. Early in 2012, his manuscript and the insights it contained still haunted me. I felt that it must be made more widely available, so I contacted James to see if he was still interested in pursuing its publication. Happily, it was also something that remained important to him, so we began to work together to bring it to its present form, with me taking on the task of expansion I originally suggested he do: considering other song traditions, song collections, and the sung poetry of songs as part of an introduction to the songs. I very much appreciate James's continuing enthusiasm for these songs and his desire to publish them, even after two decades. It has been a pleasure to collaborate with him.

Other individuals and organisations have enabled this project to proceed. In addition to providing the research environment necessary to work on this book, the Institute of Papua New Guinea Studies enabled Edward Gende and me to observe and document the Kundu and Digaso Festival and to experience some aspects of Foi music and dance first-hand, especially with Hahudi Farobo as our gracious and expert guide and teacher.

In my position as Research Associate in the Department of Anthropology, School of Culture, History, and Language, College of Asia and the Pacific at The Australian National University, I have had access to the wonderful electronic resources available through their libraries. I also appreciate comments by Steven 
Feld in reconfirming and expanding my understanding about how Bosavi sabio relates to other Kaluli genres stylistically. David Gardiner and Emily Tinker at ANU Press have greatly assisted in the production of this book.

Weiner's research materials are deposited in The Australian National University Archives (Series 432: http://archivescollection.anu.edu.au/index.php/james-fweiners-cassettes). Nick Thieberger at the Pacific and Regional Archive for Digital Sources in Endangered Cultures (PARADISEC) kindly arranged the digitisation of Weiner's recordings, so that a representative sample could be made available for this publication. Weiner's full collection of digitised recordings can be found at: http://catalog.paradisec.org.au/repository/JW1.

I am most grateful for the support from all concerned. 



\section{Women's Sago Songs (Obedobora)}

\section{Sago Song $1^{1}$}

\section{Singer: Mu'ubiaka. Recorded 18 October 1980 at Hegeso village.}

As I explained in The Empty Place, this song addresses the sun as a young girl, skipping down the sky. 'Don't set too quickly, Miss, I still have much work to do!' the singer is saying. (See Weiner 1991:120-26; for a textually simplified version of this song, see ibid. 1988a:134; finally, ibid. 1991:148-50 shows a transcription of this simplified version in Western music notation.) J online example 1 .
1. ira
$a b u-o^{2}$
wood
mallet

2. biri huie

here strike

$\begin{array}{lll}\text { 3. } & k a & \text { wasa } \\ \text { wood } & \text { woman } & \text { mallet }\end{array}$

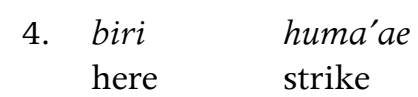

$\begin{array}{lllll}\text { 5. duma } & \text { haro } & \text { hubu } & \text { kaboneo } & \text { owa } \\ \text { mountain } & \text { climbing } & \text { struck } & \text { Miss } & \text { owa }\end{array}$
6. meye wa'ayo'o owa
not yet do not come owa

$\begin{array}{lllll}\text { 7. duma } & \text { oro } & \text { hubu } & \text { kabonere } & \text { owa } \\ \text { mountain } & \text { top } & \text { struck } & \text { Miss } & \text { owa }\end{array}$

\footnotetext{
1 The naming and numbering of songs here follows that used in The Empty Place (Weiner 1991). References to particular songs in that volume and other publications by Weiner are included in the notes prefacing the song texts.

2 The orthography used here is based on that initially developed by missionary linguist Murray Rule. For further details, see publications by Weiner (1988a:xvii-xviii; 1991:xi-xii) and Rule (1993:23-25). In particular, note that the apostrophe represents a glottal stop and that tildes indicate nasalisation of the vowels to which they are attached $(\tilde{a}, \tilde{e}, \tilde{l}, \tilde{o}, \tilde{u})$.
} 


\begin{tabular}{|c|c|c|c|c|c|c|}
\hline 8. & $\begin{array}{l}\text { meye } \\
\text { not yet }\end{array}$ & $\begin{array}{l}\text { wa'ayo'o } \\
\text { do not come }\end{array}$ & $\begin{array}{l}\text { owa } \\
\text { owa }\end{array}$ & & & \\
\hline 9. & $\begin{array}{l}\text { meye } \\
\text { not yet }\end{array}$ & $\begin{array}{l}\text { wamone } \\
\text { do not come }\end{array}$ & $\begin{array}{l}\text { owa } \\
\text { owa }\end{array}$ & & & \\
\hline 10. & $\begin{array}{l}i b u \\
\text { river }\end{array}$ & $\begin{array}{l}\text { busu } \\
\text { dappled light }\end{array}$ & $\begin{array}{l}\text { humekerabo } \\
\text { strike }+ \text { put }\end{array}$ & $\begin{array}{l}\text { kabonere } \\
\text { Miss }\end{array}$ & $\begin{array}{l}\text { owa } \\
\text { owa }\end{array}$ & \\
\hline 11. & $\begin{array}{l}\text { meye } \\
\text { not yet }\end{array}$ & $\begin{array}{l}w a^{\prime} a y o^{\prime} o \\
\text { do not come }\end{array}$ & $\begin{array}{l}\text { owa } \\
\text { owa }\end{array}$ & & & \\
\hline 12. & $\begin{array}{l}i b u \\
\text { river }\end{array}$ & $\begin{array}{l}\text { hohotogabo } \\
\text { mirror }\end{array}$ & $\begin{array}{l}\text { kabo } \\
\text { girl }\end{array}$ & $\begin{array}{l}n a-o \\
\text { I too }\end{array}$ & $\begin{array}{l}\text { owa } \\
\text { owa }\end{array}$ & \\
\hline 13. & $\begin{array}{l}\text { meye } \\
\text { not yet }\end{array}$ & $\begin{array}{l}\text { wamone } \\
\text { do not come }\end{array}$ & $\begin{array}{l}\text { owa } \\
\text { owa }\end{array}$ & & & \\
\hline 14. & $\begin{array}{l}\text { duma } \\
\text { mountain }\end{array}$ & $\begin{array}{l}\text { humegenemodobo } \\
\text { to make dark }\end{array}$ & $\begin{array}{l}\text { kabonere } \\
\text { Miss }\end{array}$ & $\begin{array}{l}\text { owa } \\
\text { owa }\end{array}$ & & \\
\hline 15. & $\begin{array}{l}\text { meye } \\
\text { not yet }\end{array}$ & $\begin{array}{l}w a^{\prime} a y o^{\prime} o \\
\text { do not come }\end{array}$ & $\begin{array}{l}\text { owa } \\
\text { owa }\end{array}$ & & & \\
\hline 16. & $\begin{array}{l}i b u \\
\text { river }\end{array}$ & $\begin{array}{l}\text { anogo } \\
\text { fish net }\end{array}$ & $\begin{array}{l}\text { hamayibu } \\
\text { to have gaps }\end{array}$ & $\begin{array}{l}\text { kabonereo } \\
\text { Miss }\end{array}$ & $\begin{array}{l}\text { owa } \\
\text { owa }\end{array}$ & \\
\hline 17. & $\begin{array}{l}\text { meya } \\
\text { not yet }\end{array}$ & $\begin{array}{l}\text { wamona } \\
\text { do not come }\end{array}$ & $\begin{array}{l}\text { owa } \\
\text { owa }\end{array}$ & & & \\
\hline 18. & $\begin{array}{l}i b u \\
\text { river }\end{array}$ & $\begin{array}{l}\text { gikoba } \\
\text { butterflies }\end{array}$ & $\begin{array}{l}\text { humogoreye } \\
\text { to scatter }\end{array}$ & $\begin{array}{l}u b u \\
\text { go }\end{array}$ & $\begin{array}{l}\text { kabonera } \\
\text { Miss }\end{array}$ & $\begin{array}{l}\text { owa } \\
\text { owa }\end{array}$ \\
\hline 19. & $\begin{array}{l}\text { meye } \\
\text { not yet }\end{array}$ & $\begin{array}{l}w a^{\prime} a y o^{\prime} o \\
\text { do not come }\end{array}$ & $\begin{array}{l}\text { owa } \\
\text { owa }\end{array}$ & & & \\
\hline 20. & $\begin{array}{l}\text { duma } \\
\text { mountain }\end{array}$ & $\begin{array}{l}\text { haro } \\
\text { climbing }\end{array}$ & $\begin{array}{l}\text { hubu } \\
\text { struck }\end{array}$ & $\begin{array}{l}\text { kabo } \\
\text { girl }\end{array}$ & $\begin{array}{l}n a^{\prime} a \\
\text { you }\end{array}$ & $\begin{array}{l}\text { owa } \\
\text { owa }\end{array}$ \\
\hline 21. & $\begin{array}{l}\text { meye } \\
\text { not yet }\end{array}$ & $\begin{array}{l}\text { wamone } \\
\text { do not come }\end{array}$ & $\begin{array}{l}\text { owa } \\
\text { owa }\end{array}$ & & & \\
\hline 22. & $\begin{array}{l}\text { meyere } \\
\text { not yet }\end{array}$ & $\begin{array}{l}\text { eya } \\
\text { eya }\end{array}$ & & & & \\
\hline
\end{tabular}




\begin{tabular}{|c|c|c|c|c|c|c|}
\hline 23. & $\begin{array}{l}\text { nomo } \\
\text { my }\end{array}$ & $\begin{array}{l}\text { ira } \\
\text { tree }\end{array}$ & $\begin{array}{l}\text { kabiri } \\
\text { kabiri mallet }\end{array}$ & $\begin{array}{l}\text { ma'oyo'o } \\
\text { to take }\end{array}$ & $\begin{array}{l}\text { eya } \\
\text { eya }\end{array}$ & \\
\hline \multirow{2}{*}{24.} & meya'are & eya & & & & \\
\hline & not yet & eya & & & & \\
\hline \multirow[t]{2}{*}{25.} & $g i$ & soboye & owa & & & \\
\hline & ground & there & owa & & & \\
\hline \multirow{2}{*}{26.} & duma & haru & huaye & eya & & \\
\hline & mountain & hill & to leave & eya & & \\
\hline \multirow{2}{*}{27.} & meya'a & umone & eya & & & \\
\hline & not yet & do not go & eya & & & \\
\hline \multirow{2}{*}{28.} & $i b u$ & damani & fufae & eya & & \\
\hline & river & Danimi & to fly & eya & & \\
\hline \multirow[t]{2}{*}{29.} & meya'a & $o^{\prime}$ oyo'o & eya & & & \\
\hline & not yet & do not go & eya & & & \\
\hline \multirow{2}{*}{30.} & duma & sonobo & kigiri & hesae & eya & \\
\hline & mountain & Yafua & base & to follow & eya & \\
\hline \multirow{2}{*}{31.} & meya'a & $o^{\prime}$ oyóo & eya & & & \\
\hline & not yet & do not go & eya & & & \\
\hline \multirow[t]{2}{*}{32.} & duma & kanawebi & hesae & eya & & \\
\hline & mountain & Kagiri & to follow & eya & & \\
\hline \multirow{2}{*}{33.} & meya & umona & eya & & & \\
\hline & not yet & do not go & eya & & & \\
\hline \multirow[t]{2}{*}{34.} & duma & gara & $u^{\prime} u b i$ & kigiri & hesae & eya \\
\hline & mountain & orphan & child & base & to follow & eya \\
\hline \multirow[t]{2}{*}{35.} & meya & $o^{\prime}$ oyo'o & eya & & & \\
\hline & not yet & do not go & eya & & & \\
\hline \multirow[t]{2}{*}{36.} & $i b u$ & webiga & fufae & eya & & \\
\hline & river & Webi source & to fly & eya & & \\
\hline \multirow{2}{*}{37.} & meye & umona & eya & & & \\
\hline & not yet & do not go & eya & & & \\
\hline
\end{tabular}




\begin{tabular}{|c|c|c|c|c|c|}
\hline 38. & $\begin{array}{l}\text { ira } \\
\text { tree }\end{array}$ & $\begin{array}{l}\text { tegare } \\
\text { ko'oya }\end{array}$ & $\begin{array}{l}\text { gifubi-e } \\
\text { canopy }\end{array}$ & $\begin{array}{l}\text { eya } \\
\text { eya }\end{array}$ & \\
\hline 39. & $\begin{array}{l}\text { meya } \\
\text { not yet }\end{array}$ & $\begin{array}{l}\text { degamone } \\
\text { to hide }\end{array}$ & $\begin{array}{l}\text { eye } \\
\text { eye }\end{array}$ & & \\
\hline 40 & $\begin{array}{l}\text { oro } \\
\text { bamboo }\end{array}$ & $\begin{array}{l}\text { yiyebi } \\
\text { small }\end{array}$ & $\begin{array}{l}\text { oro } \\
\text { top }\end{array}$ & $\begin{array}{l}\text { huae } \\
\text { strike }\end{array}$ & $\begin{array}{l}\text { eye } \\
\text { eye }\end{array}$ \\
\hline 41. & $\begin{array}{l}\text { meye } \\
\text { not yet }\end{array}$ & $\begin{array}{l}o^{\prime} \text { oyo'o } \\
\text { do not go }\end{array}$ & $\begin{array}{l}\text { dobo'o } \\
\text { spoken }\end{array}$ & $\begin{array}{l}\text { eya } \\
\text { eya }\end{array}$ & \\
\hline 42. & $\begin{array}{l}b i \\
\text { here }\end{array}$ & $\begin{array}{l}\text { yebimahone } \\
\text { do not leave }\end{array}$ & $\begin{array}{l}\text { eya } \\
\text { eya }\end{array}$ & & \\
\hline 43. & $\begin{array}{l}k u i \\
\text { sago }\end{array}$ & $\begin{array}{l}\text { tuba } \\
\text { hand }\end{array}$ & $\begin{array}{l}\text { foraye } \\
\text { broken }\end{array}$ & $\begin{array}{l}\text { ma'ayo'o } \\
\text { to take }\end{array}$ & $\begin{array}{l}\text { eye } \\
\text { eye }\end{array}$ \\
\hline 44. & $\begin{array}{l}\text { meya } \\
\text { not yet }\end{array}$ & $\begin{array}{l}o^{\prime} \text { oyo'o } \\
\text { do not go }\end{array}$ & $\begin{array}{l}\text { eye } \\
\text { eye }\end{array}$ & & \\
\hline 45. & $\begin{array}{l}k u i \\
\text { sago }\end{array}$ & $\begin{array}{l}\text { hufuruwa } \\
\text { to break apart }\end{array}$ & $\begin{array}{l}\text { ma'ayo'o } \\
\text { to take }\end{array}$ & $\begin{array}{l}\text { eye } \\
\text { eye }\end{array}$ & \\
\hline 46. & $\begin{array}{l}a i \\
\text { ai! }\end{array}$ & $\begin{array}{l}\text { meya'are } \\
\text { not yet }\end{array}$ & $\begin{array}{l}\text { eye } \\
\text { eye }\end{array}$ & & \\
\hline 47. & $\begin{array}{l}k u i \\
\text { sago }\end{array}$ & $\begin{array}{l}k a^{\prime} a b e \\
\text { difficult }\end{array}$ & $\begin{array}{l}\text { ma'ayo'o } \\
\text { to take }\end{array}$ & $\begin{array}{l}\text { eye } \\
\text { eye }\end{array}$ & \\
\hline 48. & $\begin{array}{l}\text { meya'a } \\
\text { not yet }\end{array}$ & $\begin{array}{l}o^{\prime} \text { oyo'o } \\
\text { do not go }\end{array}$ & $\begin{array}{l}\text { eye } \\
\text { eye }\end{array}$ & & \\
\hline 49. & $\begin{array}{l}\text { kui } \\
\text { sago }\end{array}$ & $\begin{array}{l}\text { tirarudia } \\
\text { to bundle }\end{array}$ & $\begin{array}{l}\text { ma'ayo'o } \\
\text { to take }\end{array}$ & $\begin{array}{l}\text { eye } \\
\text { eye }\end{array}$ & \\
\hline 50. & $\begin{array}{l}\text { meya'a } \\
\text { not yet }\end{array}$ & $\begin{array}{l}o^{\prime} \text { oyo'o } \\
\text { do not go }\end{array}$ & $\begin{array}{l}\text { eye } \\
\text { eye }\end{array}$ & & \\
\hline 51. & $\begin{array}{l}k u i \\
\text { sago }\end{array}$ & $\begin{array}{l}k a^{\prime} a b e \\
\text { difficult }\end{array}$ & $\begin{array}{l}m a^{\prime} o y o^{\prime} o \\
\text { to take }\end{array}$ & $\begin{array}{l}\text { eye } \\
\text { eye }\end{array}$ & \\
\hline 52. & $\begin{array}{l}\text { meye } \\
\text { not yet }\end{array}$ & $\begin{array}{l}\text { umona } \\
\text { do not go }\end{array}$ & $\begin{array}{l}\text { eye } \\
\text { eye }\end{array}$ & & \\
\hline
\end{tabular}




\begin{tabular}{|c|c|c|c|c|}
\hline & $\begin{array}{l}i b u \\
\text { river }\end{array}$ & $\begin{array}{l}\text { kosega } \\
\text { phlegm }\end{array}$ & $\begin{array}{l}\text { hubagiae } \\
\text { to spread }\end{array}$ & $\begin{array}{l}\text { eye } \\
\text { eye }\end{array}$ \\
\hline 54. & $\begin{array}{l}\text { meye } \\
\text { not yet }\end{array}$ & $\begin{array}{l}\text { umona } \\
\text { do not go }\end{array}$ & $\begin{array}{l}\text { eye } \\
\text { eye }\end{array}$ & \\
\hline 55. & $\begin{array}{l}i b u \\
\text { river }\end{array}$ & $\begin{array}{l}\text { hemomo'o } \\
\text { flotsam }\end{array}$ & $\begin{array}{l}\text { bagiae } \\
\text { to spread }\end{array}$ & $\begin{array}{l}\text { eye } \\
\text { eye }\end{array}$ \\
\hline 56. & $\begin{array}{l}\text { meye } \\
\text { not yet }\end{array}$ & $\begin{array}{l}\text { yebihamone } \\
\text { to leave }\end{array}$ & $\begin{array}{l}\text { eye } \\
\text { eye }\end{array}$ & \\
\hline
\end{tabular}

1. Oh sago mallet

2. Strike this sago quickly

3. Miss Sago Mallet

4. Beat this sago quickly

5. You strike the mountain side as you set, Miss

6. Do not fall so quickly

7. You strike the top of the mountain as you sink

8. Do not fall yet

9. Do not come yet

10. You reflect in dappled sparkle off the river

11. Do not fall so quickly

12. You reflect off the river like my image, girl

13. Do not come yet

14. The mountain turns dark as you set, girl

15. Do not come yet

16. You shine through the holes in the fishing nets

17. Do not come yet

18. You scatter the butterflies on the river, Miss

19. Do not fall yet

20. You strike the side of the mountain as you fall 
Songs of the Empty Place

21. Do not come so quickly

22. Do not come yet

23. I still have to hold my mallet, girl

24. Not yet, girl!

25. Don't make this ground dark yet, girl

26. Don't leave this mountain yet, girl

27. Don't go yet

28. You fly down the Danimi Creek

29. Don't go yet

30. You fall towards the bottom of Mt Yafua

31. Don't leave me yet!

32. You follow the bottom of Mt Kagiri

33. Do not go yet

34. You follow the bottom of Mt Kagiri

35. Don't go yet

36. You fly towards the head of Webi Creek

37. Don't go yet

38. You shine through the top of the ko'oya tree

39. Don't hide from me yet

40. Shining through the bamboos on the mountain top

41. Don't go, I say

42. Don't leave me here

43. I have to still beat sago

44. Do not go yet

45. I have to bundle my sago up

46. Ai! Do not go yet

47. I have to wrap my sago

48. Do not go yet

49. I have to wrap up my sago

50. Do not go yet 
51. I have a lot of work to do

52. Do not go yet

53. You spread along the river surface like froth

54. Do not go yet

55. You sparkle off the river flotsam

56. Do not leave me yet

\section{Sago Song 2}

\section{Singer: Kunuhuaka. Recorded 26 November 1980 at Hegeso village.}

A woman, angry that her husband berates her for not working, rebukes him in the following sago song. (Figure 2 in this volume is a music transcription of lines 10-14.) J online example 2.

\begin{tabular}{llllll} 
1. $\begin{array}{l}\text { kare } \\
\text { women's }\end{array}$ & $\begin{array}{l}\text { kui } \\
\text { sago }\end{array}$ & $\begin{array}{l}\text { ini } \\
\text { cook }\end{array}$ & $\begin{array}{l}\text { dobo'o } \\
\text { spoken }\end{array}$ & $\begin{array}{l}\text { owa } \\
\text { owa }\end{array}$ \\
\hline $\begin{array}{l}\text { 2. nena'a } \\
\text { no reason }\end{array}$ & $\begin{array}{l}\text { doma'ae } \\
\text { say }\end{array}$ & $\begin{array}{l}\text { owa } \\
\text { owa }\end{array}$ & & \\
3. $\begin{array}{l}\text { wana'aro } \\
\text { evening }\end{array}$ & kui & sago & ini & dobo'o & owa \\
cowa & spoken & owa
\end{tabular}

4. Kama doma'ae eye
no reason say

$\begin{array}{llll}\text { 5. nari } & \text { hirima } & \text { diburo } & \text { owa } \\ \text { nari pitpit } & \text { plant } & \text { talk } & \text { owa }\end{array}$

$\begin{array}{lll}\text { 6. nena } & \text { doma'ae } & \text { owa } \\ \text { no reason } & \text { say } & \text { owa }\end{array}$

\begin{tabular}{|c|c|c|}
\hline $\begin{array}{l}\text { 7. senage } \\
\text { senage pitpit }\end{array}$ & $\begin{array}{l}\text { hirima } \\
\text { plant }\end{array}$ & $\begin{array}{l}\text { dibure } \\
\text { said }\end{array}$ \\
\hline
\end{tabular}

$\begin{array}{lll}\text { 8. kama dee } & \text { eye } \\ \text { mind } & \text { say } & \text { eye }\end{array}$




\begin{tabular}{|c|c|c|c|c|c|c|}
\hline 9. & $\begin{array}{l}\text { dimu } \\
\text { dimu pitpit }\end{array}$ & $\begin{array}{l}\text { hirima } \\
\text { plant }\end{array}$ & $\begin{array}{l}\text { dibure } \\
\text { said }\end{array}$ & $\begin{array}{l}\text { oye } \\
\text { oye }\end{array}$ & & \\
\hline 10. & $\begin{array}{l}\text { kama } \\
\text { mind }\end{array}$ & $\begin{array}{l}\text { doma'ae } \\
\text { tell }\end{array}$ & $\begin{array}{l}\text { eye } \\
\text { eye }\end{array}$ & & & \\
\hline 11. & $\begin{array}{l}\text { sona } \\
\text { sona }\end{array}$ & $\begin{array}{l}\text { iburi } \\
\text { iburi }\end{array}$ & $\begin{array}{l}\text { hirima } \\
\text { plant }\end{array}$ & $\begin{array}{l}\text { dibure } \\
\text { said }\end{array}$ & $\begin{array}{l}\text { owa } \\
\text { owa }\end{array}$ & \\
\hline 12. & $\begin{array}{l}\text { nena'a } \\
\text { no reason }\end{array}$ & $\begin{array}{l}\text { dee } \\
\text { say }\end{array}$ & $\begin{array}{l}\text { eye } \\
\text { eye }\end{array}$ & & & \\
\hline 13. & $\begin{array}{l}\text { wãsia } \\
\text { pitpit }\end{array}$ & $\begin{array}{l}\text { diamoro } \\
\text { diamoro }\end{array}$ & $\begin{array}{l}\text { hirima } \\
\text { plant }\end{array}$ & $\begin{array}{l}\text { dibure } \\
\text { said }\end{array}$ & $\begin{array}{l}o w a \\
\text { owa }\end{array}$ & \\
\hline 14. & $\begin{array}{l}\text { kama } \\
\text { mind }\end{array}$ & $\begin{array}{l}\text { doma'ae } \\
\text { tell }\end{array}$ & $\begin{array}{l}\text { eye } \\
\text { eye }\end{array}$ & & & \\
\hline 15. & $\begin{array}{l}u^{\prime} u b i \\
\text { children }\end{array}$ & $\begin{array}{l}\text { kama } \\
\text { female }\end{array}$ & $\begin{array}{l}\text { ere } \\
\text { mind }\end{array}$ & $\begin{array}{l}\text { dibure } \\
\text { said }\end{array}$ & $\begin{array}{l}\text { owa } \\
\text { owa }\end{array}$ & \\
\hline 16. & $\begin{array}{l}\text { nena'a } \\
\text { no reason }\end{array}$ & $\begin{array}{l}\text { doma'ae } \\
\text { tell }\end{array}$ & $\begin{array}{l}\text { doba'abe } \\
\text { should say }\end{array}$ & $\begin{array}{l}\text { eye } \\
\text { eye }\end{array}$ & & \\
\hline 17. & $\begin{array}{l}\text { ira } \\
\text { tree }\end{array}$ & $\begin{array}{l}d o^{\prime} a \\
d o^{\prime} a\end{array}$ & $\begin{array}{l}g a \\
\text { base }\end{array}$ & $\begin{array}{l}\text { nereye } \\
\text { burn }\end{array}$ & $\begin{array}{l}\text { dibure } \\
\text { said }\end{array}$ & $\begin{array}{l}\text { owa } \\
\text { owa }\end{array}$ \\
\hline 18. & $\begin{array}{l}\text { kama'a } \\
\text { know }\end{array}$ & $\begin{array}{l}\text { dee } \\
\text { say }\end{array}$ & $\begin{array}{l}\text { eye } \\
\text { eye }\end{array}$ & & & \\
\hline 19. & $\begin{array}{l}\text { ira } \\
\text { tree }\end{array}$ & $\begin{array}{l}u b i \\
u b i\end{array}$ & $\begin{array}{l}g a \\
\text { base }\end{array}$ & $\begin{array}{l}\text { nereye } \\
\text { burn }\end{array}$ & $\begin{array}{l}\text { dibure } \\
\text { said }\end{array}$ & $\begin{array}{l}\text { owa } \\
\text { owa }\end{array}$ \\
\hline 20. & $\begin{array}{l}\text { nena'a } \\
\text { no reason }\end{array}$ & $\begin{array}{l}\text { doma'ae } \\
\text { say }\end{array}$ & $\begin{array}{l}\text { eye } \\
\text { eye }\end{array}$ & & & \\
\hline 21. & $\begin{array}{l}\text { ira } \\
\text { tree }\end{array}$ & $\begin{array}{l}\text { senage } \\
\text { senage }\end{array}$ & $\begin{array}{l}g a \\
\text { base }\end{array}$ & $\begin{array}{l}\text { kea } \\
\text { burn }\end{array}$ & $\begin{array}{l}\text { diburo } \\
\text { talk }\end{array}$ & $\begin{array}{l}\text { owa } \\
\text { owa }\end{array}$ \\
\hline 22. & $\begin{array}{l}\text { nena'a } \\
\text { no reason }\end{array}$ & $\begin{array}{l}\text { doba'abe } \\
\text { should say }\end{array}$ & $\begin{array}{l}\text { eye } \\
\text { eye }\end{array}$ & & & \\
\hline 23. & $\begin{array}{l}\text { ira } \\
\text { tree }\end{array}$ & $\begin{array}{l}\text { homono } \\
\text { homono }\end{array}$ & $\begin{array}{l}g a \\
\text { base }\end{array}$ & $\begin{array}{l}\text { nareye } \\
\text { burn }\end{array}$ & $\begin{array}{l}\text { diburo } \\
\text { talk }\end{array}$ & $\begin{array}{l}\text { owa } \\
\text { owa }\end{array}$ \\
\hline
\end{tabular}




\begin{tabular}{|c|c|c|c|c|c|c|}
\hline \multirow{2}{*}{\multicolumn{2}{|c|}{$\begin{array}{l}\text { 24. kama'a } \\
\text { know }\end{array}$}} & \multirow{2}{*}{$\begin{array}{l}\text { dee } \\
\text { say }\end{array}$} & \multicolumn{4}{|l|}{ eye } \\
\hline & & & eye & & & \\
\hline \multirow[t]{2}{*}{25.} & buru & kirari & $m a$ & dibure & owa & \\
\hline & black & rope & take & said & owa & \\
\hline \multirow[t]{2}{*}{26.} & $n e n a^{\prime} a$ & doma'ae & eye & & & \\
\hline & no reason & say & eye & & & \\
\hline \multirow{2}{*}{27.} & gãbu & kirari & $m a$ & dibure & owa & \\
\hline & piebald & rope & take & said & owa & \\
\hline \multirow[t]{2}{*}{28.} & $n e n a^{\prime} a$ & dee & eye & & & \\
\hline & no reason & say & eye & & & \\
\hline \multirow[t]{2}{*}{29.} & wana'ari & kui & ini & dibure & owa & \\
\hline & mid-day & sago & cook & said & $o w a$ & \\
\hline \multirow[t]{2}{*}{30.} & $k a m a^{\prime} a$ & doma'ae & eye & & & \\
\hline & know & tell & eye & & & \\
\hline \multirow[t]{2}{*}{31.} & kusu & $u^{\prime} u b i$ & era & diburo & owa & \\
\hline & cross-cousin & children & mind & talk & $o w a$ & \\
\hline \multirow[t]{2}{*}{32.} & $n e n a^{\prime} a$ & dee & eye & & & \\
\hline & no reason & say & eye & & & \\
\hline \multirow[t]{2}{*}{33.} & $b a^{\prime} a$ & ga & $k u i$ & ini & dibureo & owa \\
\hline & boy & belongs to & sago & cook & spoken & owa \\
\hline \multirow[t]{2}{*}{34.} & $n e n a^{\prime} a$ & to & $i b a^{\prime} a e$ & eye & & \\
\hline & no reason & this & is & eye & & \\
\hline \multirow[t]{2}{*}{35.} & magoro & kui & ini & diburo & owa & \\
\hline & young man & sago & cook & talk & owa & \\
\hline \multirow[t]{2}{*}{36.} & $n e n a^{\prime} a$ & dee & eye & & & \\
\hline & no reason & say & eye & & & \\
\hline \multirow[t]{2}{*}{37.} & $i b u$ & viri & diburo & owa & & \\
\hline & water & fill up & talk & owa & & \\
\hline \multirow[t]{2}{*}{38.} & $n e n a^{\prime} a$ & doma'ae & eye & & & \\
\hline & no reason & tell & eye & & & \\
\hline
\end{tabular}




\begin{tabular}{|c|c|c|c|c|c|}
\hline & $\begin{array}{l}\text { kumi } \\
\text { cross-cousin }\end{array}$ & $\begin{array}{l}k a \\
\text { wife }\end{array}$ & $\begin{array}{l}\text { era } \\
\text { mind }\end{array}$ & $\begin{array}{l}\text { dibure } \\
\text { said }\end{array}$ & $\begin{array}{l}\text { owa } \\
\text { owa }\end{array}$ \\
\hline 40 & $\begin{array}{l}\text { nena'ae } \\
\text { for no reason }\end{array}$ & $\begin{array}{l}\text { dee } \\
\text { say }\end{array}$ & $\begin{array}{l}\text { eye } \\
\text { eye }\end{array}$ & & \\
\hline 41. & $\begin{array}{l}\text { kuidobo } \\
\text { kuidobo }\end{array}$ & $\begin{array}{l}\text { sa'abiyumo } \\
\text { Sa'abiyu }\end{array}$ & $\begin{array}{l}\text { owa } \\
\text { owa }\end{array}$ & & \\
\hline 42. & $\begin{array}{l}\text { hua } \\
\text { killed }\end{array}$ & $\begin{array}{l}\text { mohũgaiye } \\
\text { discarded }\end{array}$ & $\begin{array}{l}\text { eye } \\
\text { eye }\end{array}$ & & \\
\hline 43. & $\begin{array}{l}\text { yuaka } \\
\text { Yuaka }\end{array}$ & $\begin{array}{l}\text { iribinunemo } \\
\text { Iribinu }\end{array}$ & $\begin{array}{l}\text { owa } \\
\text { owa }\end{array}$ & & \\
\hline 44. & $\begin{array}{l}\text { humofo'owaiye } \\
\text { killed and thro }\end{array}$ & own away & $\begin{array}{l}\text { eye } \\
\text { eye }\end{array}$ & & \\
\hline
\end{tabular}

1. 'Cook my evening sago!' you say

2. Without a care, you order me

3. 'Cook my quick sago!' you say

4. For no reason you tell me

5. Go plant the nari pitpit

6. For no reason, tell me!

7. Go plant the senage pitpit

8. Thoughtlessly, you command me

9. Go plant the dimu pitpit

10. Tell me you have a reason!

11. Go plant the sona iburi leaves, you say

12. Tell me for no reason

13. Go plant the diamoro pitpit, you say

14. You thoughtlessly tell me

15. Feed our little girls, you say

16. Without a care must you tell me

17. Burn the base of the do'a tree, you say 
18. Tell me what you want

19. Burn the base of the $u b i$ tree, you say

20. For no reason, tell me!

21. Burn the base of the senage tree, you say

22. You should tell me for no reason?

23. Burn the base of the homono tree, you say

24. You should tell me what you are thinking

25. Take the rope of the black pig, you say

26. For no reason, you tell me!

27. Take the rope of the piebald pig, you say

28. For no reason, you say to me

29. Cook my quick sago, you order me

30. Tell me what you are thinking

31. Mind your little cross-cousins, you say

32. For no reason, tell me

33. Mind your sister's child, you tell me

34. Is this for reason you say

35. Cook sago for the young men, you say

36. Say what you are thinking

37. Fetch water, you say

38. For no reason, tell me

39. Fetch water for your cross-cousins' wives, you say

40. For no reason, tell me

41. The Kuidobo man, Sa'abiyumo

42. Killed and left in the bush

43. His wife, Yuaka, daughter of Iribinu

44. Killed and thrown away 


\section{Sago Song 3}

\section{Singer: Gebo. Recorded 18 October 1980 at Hegeso village.}

Gebo, an elderly widow, sang this song about her deceased husband, Kigiri. She recalls the places where her husband made traps, cut wood grubs, and dammed small creeks for fish. Because he can no longer go there, the bush and forest have obliterated the signs of human intervention. The final lines reference their two deceased children (although there were three other children living at the time). The lines also note that although Kigiri was genealogically of a So' onedobo clan lineage, he was adopted by the Orodobo clan and his children were also Orodobo. (See Weiner 1988a:132.) J J online example 3.

\begin{tabular}{|c|c|c|c|c|}
\hline $\begin{array}{l}\text { 1. } \quad b a^{\prime} a \\
\text { boy }\end{array}$ & $\begin{array}{l}n a^{\prime} a \\
\text { your }\end{array}$ & $\begin{array}{l}\text { ira } \\
\text { tree }\end{array}$ & $\begin{array}{l}\text { sabe } \\
\text { sabe }\end{array}$ & $\begin{array}{l}\text { hũga } \\
\text { larvae }\end{array}$ \\
\hline
\end{tabular}

2. aoda'ae owe

bush covered up owe

\begin{tabular}{|c|c|c|c|c|}
\hline $\begin{array}{l}\text { 3. } b a^{\prime} a \\
\text { boy }\end{array}$ & $\begin{array}{l}n a^{\prime} a \\
\text { your }\end{array}$ & $\begin{array}{l}\text { ira } \\
\text { tree }\end{array}$ & $\begin{array}{l}d a b i \\
d a b i\end{array}$ & $\begin{array}{ll}\text { bu'uni } & \text { derege } \\
\text { deadfall teach }\end{array}$ \\
\hline
\end{tabular}

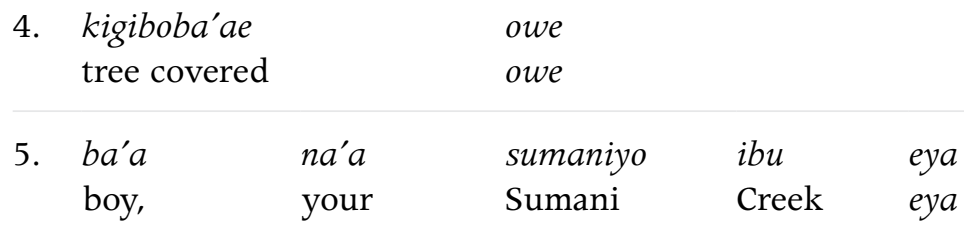

6. kigiboba'ae owe

tree covered owe

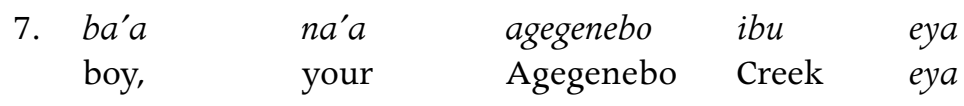

8. aoda'ae owe

bush covered up owe

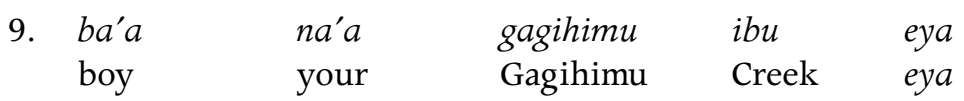




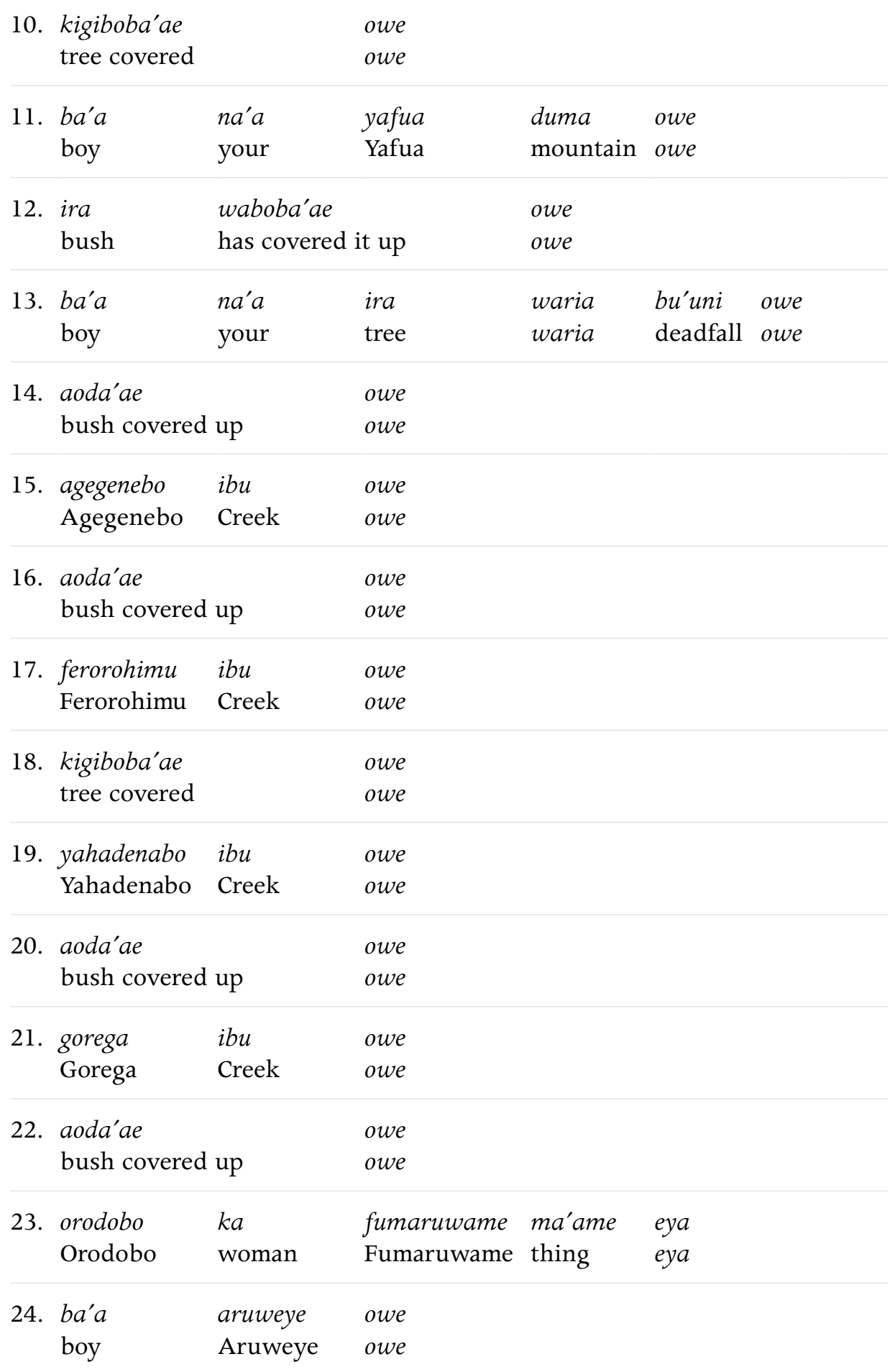


25. ira so'onedobo bugimena ma'ame eya

line So'onedobo Bugimena

thing

eya

26. Kigiri-a owe

Kigiri owe

1. Boy, your sabe tree wood grubs

2. The bush has covered them up

3. Boy, the place where you showed [others] where you made your dabi tree traps

4. The bush has covered them up

5. Boy, your Sumani Creek

6. The bush has covered it up

7. Boy, your Agegenebo Creek

8. The bush has covered it up

9. Boy, your Gagihimu Creek

10. The bush has covered it up

11. Boy, your Yafua Mountain

12. The bush has covered it up

13. Boy, your waria tree deadfall

14. The bush has covered it up

15. Agegenebo Creek

16. The bush has covered it up

17. Ferorohimu Creek

18. The bush has covered it up

19. Yahadenabo Creek

20. The bush has covered it up

21. Gorega Creek

22. The bush has covered it up

23. (My) deceased Orodobo clan daughter Fumaruwame

24. (My) deceased son Aruweye 
25. The line of the So'onedobo man Bugimena

26. Kigiri

\section{Sago Song 4}

\section{Singer: Kunuhuaka. Recorded 26 November 1980 at Hegeso village.}

As I described in The Empty Place, Kunuhuaka's mother taught her this song. She composed it once when she was at Ayamo and her son Ta'anobo became lost. She called out to him at the places she searched for him, but only heard the sound of the birds calling, i! i! wo! wo! (See Weiner 1988a:132-33; 1991:20-22.)

J online example 4.

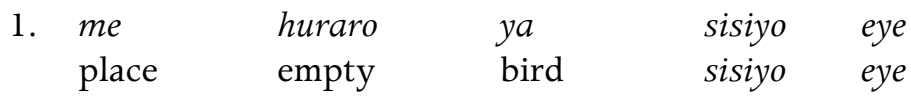

2. me odo'oiye eye

speech cannot speak eye

$\begin{array}{llllll}\text { 3. duma } & \text { hau } & \text { me } & \text { ya } & u-o & \text { eya } \\ \text { mountain } & \text { side } & \text { place } & \text { bird } & u & \text { eye }\end{array}$

\begin{tabular}{|c|c|c|c|c|}
\hline 4. & $\begin{array}{l}\text { me } \\
\text { speech }\end{array}$ & $\begin{array}{l}\text { odibik } \\
\text { does I }\end{array}$ & & $\begin{array}{l}\text { owa } \\
\text { owa }\end{array}$ \\
\hline 5. & kui & yamo & ya & sisiye \\
\hline & sago & yamo & bird & sisiyu \\
\hline
\end{tabular}
6. megenebo deyiye you only do not speak

$\begin{array}{llll}\text { 7. } & \text { gabe } & \text { ya } & \text { muri-e eye } \\ \text { sago gabe } & \text { bird } & \text { muri eye }\end{array}$
8. na'abo deyiye
to you do not speak
9. ibu ama'afu geno ya sisiye creek Ama'afu river bend bird sisiyu


$\begin{array}{ll}\text { 10. nebo } & \text { deyiye } \\ \text { you alone } & \text { do not speak }\end{array}$

$\begin{array}{lllll}\text { 11. } i b u & \text { firigiri } & \text { tage } & \text { ya } & u \\ \text { creek } & \text { Firigiri } & \text { mouth } & \text { bird } & u\end{array}$

12. megenebo deyiye you only do not speak

\begin{tabular}{|c|c|c|c|c|}
\hline 13. & $\begin{array}{l}i b u \\
\text { creek }\end{array}$ & $\begin{array}{l}\text { segenabi } \\
\text { Segenabi }\end{array}$ & $\begin{array}{l}\text { ya } \\
\text { bird }\end{array}$ & $\begin{array}{l}u \\
u\end{array}$ \\
\hline 14. & $\begin{array}{l}\text { ne } \\
\text { you }\end{array}$ & $\begin{array}{l}\text { odibikerayiye } \\
\text { do not speak }\end{array}$ & & \\
\hline 15. & $\begin{array}{l}i b u \\
\text { creek }\end{array}$ & $\begin{array}{l}\text { saburuba } \\
\text { Saburaba }\end{array}$ & $\begin{array}{l}\text { ya } \\
\text { bird }\end{array}$ & $\begin{array}{l}\text { muri-c } \\
\text { muri }\end{array}$ \\
\hline 16. & $\begin{array}{l}\text { ne } \\
\text { you }\end{array}$ & $\begin{array}{l}\text { odeyiye } \\
\text { do not speak }\end{array}$ & & \\
\hline 17. & $\begin{array}{l}i b u \\
\text { creek }\end{array}$ & $\begin{array}{l}d a \tilde{r i} \\
\text { Dãri }\end{array}$ & $\begin{array}{l}\text { ya } \\
\text { bird }\end{array}$ & $\begin{array}{l}\text { sisiye } \\
\text { sisiyu }\end{array}$ \\
\hline
\end{tabular}

18. ne odeyiye

you do not speak

$\begin{array}{lll}\text { 19. duma } & \text { sobore } & \text { kigiri } \\ \text { mountain } & \text { Sobore } & \text { base }\end{array}$

20. megene odeyiye

you only do not call out

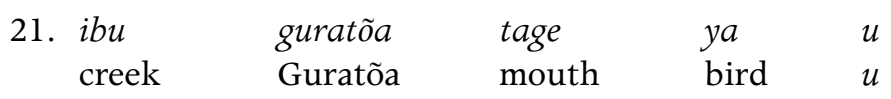

$\begin{array}{ll}\text { 22. ne } & \text { odibikerayiye } \\ \text { you } & \text { do not call ou }\end{array}$

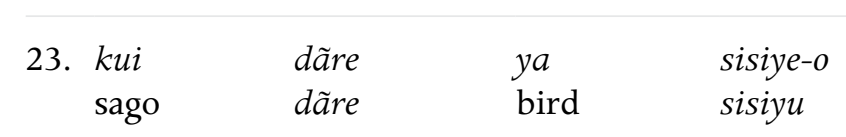

24. ne odibikiribubiye

you do not speak out 


\begin{tabular}{|c|c|c|c|c|}
\hline & $\begin{array}{l}\text { kui } \\
\text { sago }\end{array}$ & $\begin{array}{l}\text { yamo } \\
\text { yamo }\end{array}$ & $\begin{array}{l}\text { ya } \\
\text { bird }\end{array}$ & $\begin{array}{l}\text { sisiye-o } \\
\text { sisiyu }\end{array}$ \\
\hline & $\begin{array}{l}n a^{\prime} a \\
\text { you }\end{array}$ & $\begin{array}{l}\text { odeyiye } \\
\text { do not speak }\end{array}$ & & \\
\hline & $\begin{array}{l}\text { yegena } \\
\text { Yegena }\end{array}$ & $\begin{array}{l}\text { ya } \\
\text { bird }\end{array}$ & $\begin{array}{l}\text { muri-o } \\
\text { muri }\end{array}$ & \\
\hline 28. & $\begin{array}{l}\text { ne } \\
\text { you }\end{array}$ & $\begin{array}{l}\text { odeyiye } \\
\text { do not call ou }\end{array}$ & & \\
\hline 29. & $\begin{array}{l}\text { sui } \\
\text { cane }\end{array}$ & $\begin{array}{l}\text { geroa } \\
\text { gerewa }\end{array}$ & $\begin{array}{l}\text { ya } \\
\text { bird }\end{array}$ & $\begin{array}{l}\text { muri-o } \\
\text { muri }\end{array}$ \\
\hline 30. & $\begin{array}{l}\text { ne } \\
\text { you }\end{array}$ & $\begin{array}{l}\text { odeyiye } \\
\text { do not call ou }\end{array}$ & & \\
\hline 31. & $\begin{array}{l}\text { yegena } \\
\text { Yegena }\end{array}$ & $\begin{array}{l}\text { awa } \\
\text { empty place }\end{array}$ & $\begin{array}{l}\text { ya } \\
\text { bird }\end{array}$ & $\begin{array}{l}\text { sisiye } \\
\text { sisiyu }\end{array}$ \\
\hline 32. & $\begin{array}{l}\text { mero } \\
\text { another }\end{array}$ & $\begin{array}{l}\text { odo'oyiye } \\
\text { cannot call ou }\end{array}$ & & \\
\hline 33. & $\begin{array}{l}\text { duma } \\
\text { mountain }\end{array}$ & $\begin{array}{l}\text { weyeru } \\
\text { Weyeru }\end{array}$ & $\begin{array}{l}\text { ya } \\
\text { bird }\end{array}$ & $\begin{array}{l}\text { muri-o } \\
\text { muri }\end{array}$ \\
\hline 34. & $\begin{array}{l}\text { na } \\
\text { you }\end{array}$ & $\begin{array}{l}\text { odibihayiye } \\
\text { do not call ou }\end{array}$ & & \\
\hline 35. & $\begin{array}{l}i b u \\
\text { creek }\end{array}$ & $\begin{array}{l}\tilde{i} s a \\
\text { Issa }\end{array}$ & $\begin{array}{l}\text { ya } \\
\text { bird }\end{array}$ & $\begin{array}{l}\text { yiyo } \\
\text { yiyo }\end{array}$ \\
\hline 36. & $\begin{array}{l}\text { nere } \\
\text { you alone }\end{array}$ & $\begin{array}{l}\text { odibihayiye } \\
\text { do not call ou }\end{array}$ & & \\
\hline 37. & $\begin{array}{l}i b u \\
\text { creek }\end{array}$ & $\begin{array}{l}\text { dãri } \\
\text { Dãri }\end{array}$ & $\begin{array}{l}\text { ya } \\
\text { bird }\end{array}$ & $\begin{array}{l}\text { muri-o } \\
\text { muri }\end{array}$ \\
\hline 38. & $\begin{array}{l}\text { na'abore } \\
\text { you only }\end{array}$ & $\begin{array}{l}\text { deyiye } \\
\text { do not speak }\end{array}$ & & \\
\hline 39. & $\begin{array}{l}\text { aboragemo } \\
\text { Aboragemo }\end{array}$ & $\begin{array}{l}\text { ya } \\
\text { bird }\end{array}$ & $\begin{array}{l}u \\
u\end{array}$ & \\
\hline
\end{tabular}




\begin{tabular}{|c|c|c|c|}
\hline 40. & $\begin{array}{l}\text { nebo } \\
\text { you alone }\end{array}$ & $\begin{array}{l}\text { dibihayiye } \\
\text { do not speak }\end{array}$ & \\
\hline 41. & $\begin{array}{l}a b u \\
\text { mallet }\end{array}$ & $\begin{array}{l}\text { biri-o } \\
\text { this }\end{array}$ & \\
\hline 42. & $\begin{array}{l}a^{\prime} a \\
\text { quickly }\end{array}$ & $\begin{array}{l}\text { huma'ae } \\
\text { strike }\end{array}$ & \\
\hline 43. & $\begin{array}{l}\text { ta'anobo } \\
\text { Ta'anobo }\end{array}$ & $\begin{array}{l}\text { ma'ame } \\
\text { thing }\end{array}$ & $\begin{array}{l}\text { odibua } \\
\text { calls out }\end{array}$ \\
\hline 44. & \multicolumn{3}{|c|}{$\begin{array}{l}\text { dibikerage } \\
\text { keeps calling out }\end{array}$} \\
\hline 45. & $\begin{array}{l}\text { ya } \\
\text { bird }\end{array}$ & $\begin{array}{l}y a^{\prime} \text { oe } \\
\text { namesake }\end{array}$ & $\begin{array}{l}\text { ma'ame } \\
\text { thing }\end{array}$ \\
\hline
\end{tabular}

46. dibihage

keeps calling out

1. In this uninhabited place I hear the sisiyu bird

2. But I hear no men

3. The mountain side, the $u$ bird

4. But I hear no men's speech

5. At the place of the yamo sago, the sisiyu bird

6. But you only I hear not

7. Where the gabe sago is, the muri bird

8. But to me you do not speak

9. At the bend in Ama'afu Creek, the sisiyu bird

10. But you alone do not speak

11. At the mouth of the Fifigiri Creek, the $u$ bird

12. But you alone speak not

13. At Segenabi Creek, the $u$ bird

14. But you do not call out

15. At Saburuba Creek, the muri bird

16. But you do not speak 
17. At Dãri Creek, the sisiyu bird

18. But you do not speak

19. At the base of Mt Sobore

20. You only do not call out

21. At the mouth of Guratõa Creek, the $u$ bird

22. But you do not sing out

23. At the place of the dãre sago, the sisiyu bird

24. But you do not speak

25. At the place of the yamo sago, the sisiyu bird

26. But you I hear not

27. At Yegena, the muri bird

28. But you do not call out

29. At the place of the geroa cane, the muri bird

30. But you do not call out

31. At the empty place Yegena, the sisiyu bird

32. But I hear no other sound

33. At Mt Weyeru, the muri bird

34. But you do not call out

35. At Ĩsa Creek, the yiyo bird

36. But you alone do not call out

37. At Dãri Creek, the muri bird

38. But you only do not speak

39. At Aboragemo Creek, the $u$ bird

40. But you alone do not speak

41. This sago mallet

42. Strike quickly

43. Ta'anobo is calling out

44. He keeps calling out

45. Ta'anobo's namesake, the bird

46. He keeps calling out 


\section{Sago Song 5}

\section{Singer: Gebo. Recorded 18 October 1980 at Hegeso village.}

In The Empty Place, I related how Gebo composed this song after her son, Yaroge, was taken to Mendi for questioning by the police following the suicide of his wife. As in the previous song, the silence of the addressed man is heightened in a dramatic way by contrasting it with the sound of something else, in this case, the aeroplane rather than birds. Gebo also refers to the white shirt and shoes which is the educated, white-collar Papua New Guinean's typical clothing. (See Weiner 1991:126-27, 139-41.) J online example 5.

\begin{tabular}{|c|c|c|c|c|c|}
\hline $\begin{array}{l}\text { 1. } \quad b a^{\prime} a \\
\text { boy }\end{array}$ & $\begin{array}{l}n a^{\prime} a \\
\text { your }\end{array}$ & $\begin{array}{l}\text { bare } \\
\text { aeroplane }\end{array}$ & $\begin{array}{l}\text { awa } \\
\text { up }\end{array}$ & $\begin{array}{l}\text { hua } \\
\text { struck }\end{array}$ & $\begin{array}{l}\text { ubo'ora } \\
\text { gone }\end{array}$ \\
\hline
\end{tabular}

2. do'oyera $\quad \begin{aligned} & \text { owe } \\ & \text { did not tell }\end{aligned}$

$\begin{array}{llll}\text { 3. } \begin{array}{lll}\text { ba'a } \\ \text { boy }\end{array} \text { you } & \text { bare kuabogabo'ore } \\ \text { boy } & \text { aeroplane hummed } & \text { eya }\end{array}$

$\begin{array}{llllll}\text { 4. dia } & \begin{array}{l}\text { o'abibi-o } \\ \text { saying } \\ \text { wanted to }\end{array} & \begin{array}{l}\text { eya } \\ \text { eya }\end{array} & & & \\ \text { 5. } \begin{array}{l}\text { ba'a } \\ \text { boy }\end{array} & \begin{array}{l}n a^{\prime} a \\ \text { your }\end{array} & \begin{array}{l}\text { kabe } \\ \text { man }\end{array} & \begin{array}{l}\text { ensu } \\ \text { shoes }\end{array} & \begin{array}{l}\text { ababo walk } \\ \text { hibabo'ore owe }\end{array} \\ \text { embark owe }\end{array}$
6. nabo do'oyere owe to me did not say owe

7. do'abibidobo owe could not tell owe

\begin{tabular}{|c|c|c|c|c|}
\hline $\begin{array}{l}\text { 8. } \quad b a^{\prime} a \\
\text { boy }\end{array}$ & $\begin{array}{l}n a^{\prime} a \\
\text { your }\end{array}$ & $\begin{array}{l}k o s a^{\prime} a \\
\text { shirt }\end{array}$ & $\begin{array}{l}\text { fabo } \\
\text { white }\end{array}$ & $\begin{array}{l}\text { hibabo'ore } \\
\text { embark }\end{array}$ \\
\hline
\end{tabular}

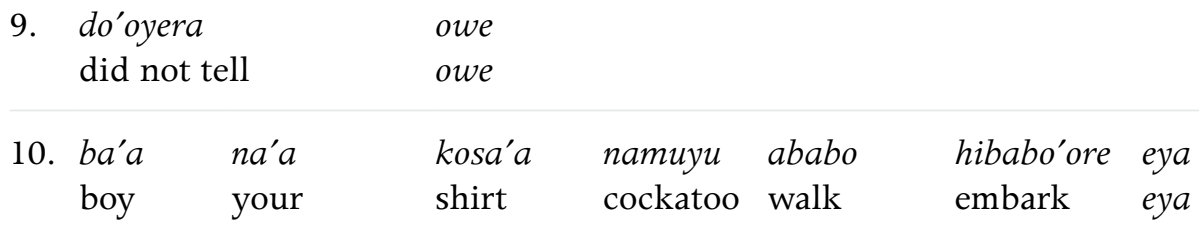




\begin{tabular}{|c|c|c|c|c|c|c|c|}
\hline 11. & $\begin{array}{l}\text { dia } \\
\text { saying }\end{array}$ & $\begin{array}{l}\text { o'oyera } \\
\text { did not go }\end{array}$ & $\begin{array}{l}\text { owe } \\
\text { owe }\end{array}$ & & & & \\
\hline 12. & $\begin{array}{l}b a^{\prime} a \\
\text { boy }\end{array}$ & $\begin{array}{l}n a^{\prime} a \\
\text { your }\end{array}$ & $\begin{array}{l}\text { duma } \\
\text { mountain }\end{array}$ & $\begin{array}{l}a^{\prime} o \\
\text { cloud }\end{array}$ & $\begin{array}{l}\text { hugoreye } \\
\text { pierced }\end{array}$ & $\begin{array}{l}\text { ubo'ore } \\
\text { gone }\end{array}$ & $\begin{array}{l}\text { eya } \\
\text { eya }\end{array}$ \\
\hline 13. & $\begin{array}{l}\text { dia } \\
\text { saying }\end{array}$ & $\begin{array}{l}o^{\prime} a b i b i-o \\
\text { wanted to }\end{array}$ & $\begin{array}{l}\text { owe } \\
\text { owe }\end{array}$ & & & & \\
\hline 14. & $\begin{array}{l}f u f u \\
\text { neck }\end{array}$ & $\begin{array}{l}\text { masibu } \\
\text { necklace }\end{array}$ & $\begin{array}{l}\text { hua } \\
\text { mother }\end{array}$ & $\begin{array}{l}\text { owe } \\
\text { owe }\end{array}$ & & & \\
\hline 15. & $\begin{array}{l}\text { do'oyera } \\
\text { did not te }\end{array}$ & & $\begin{array}{l}\text { owe } \\
\text { owe }\end{array}$ & & & & \\
\hline 16. & $\begin{array}{l}y a \\
\text { arm }\end{array}$ & $\begin{array}{l}\text { masibu } \\
\text { necklace }\end{array}$ & $\begin{array}{l}\text { hua } \\
\text { mother }\end{array}$ & $\begin{array}{l}\text { owe } \\
\text { owe }\end{array}$ & & & \\
\hline 17. & $\begin{array}{l}\text { dia } \\
\text { saying }\end{array}$ & $\begin{array}{l}\text { u'abibio } \\
\text { should have }\end{array}$ & $\begin{array}{l}\text { owe } \\
\text { owe }\end{array}$ & & & & \\
\hline 18. & $\begin{array}{l}g \tilde{o} \\
\text { string bag }\end{array}$ & & $\begin{array}{l}\text { hage } \\
\text { two }\end{array}$ & $\begin{array}{l}\text { hagikabo'o } \\
\text { carried }\end{array}$ & ore & $\begin{array}{l}\text { owe } \\
\text { owe }\end{array}$ & \\
\hline 19. & $\begin{array}{l}\text { dia } \\
\text { saying }\end{array}$ & $\begin{array}{l}o^{\prime} a b i b i-o \\
\text { wanted to }\end{array}$ & $\begin{array}{l}\text { owe } \\
\text { owe }\end{array}$ & & & & \\
\hline 20. & $\begin{array}{l}\text { awa } \\
\text { hand }\end{array}$ & $\begin{array}{l}\text { masibu } \\
\text { necklace }\end{array}$ & $\begin{array}{l}\text { hua } \\
\text { mother }\end{array}$ & $\begin{array}{l}\text { owe } \\
\text { owe }\end{array}$ & & & \\
\hline 21. & $\begin{array}{l}\text { dia } \\
\text { saying }\end{array}$ & $\begin{array}{l}\text { o'oyera } \\
\text { did not go }\end{array}$ & $\begin{array}{l}\text { owe } \\
\text { owe }\end{array}$ & & & & \\
\hline 22. & $\begin{array}{l}\text { orodobo } \\
\text { Orodobo }\end{array}$ & $\begin{array}{l}k a \\
\text { woman }\end{array}$ & $\begin{array}{l}\text { gebo } \\
\text { Gebo }\end{array}$ & $\begin{array}{l}\text { ma'ame } \\
\text { thing }\end{array}$ & $\begin{array}{l}\text { eya } \\
\text { eya }\end{array}$ & & \\
\hline
\end{tabular}

23. yaroge-o owe

Yaroge owe

24. so'onedobo

kigirimone

owe

So'onedobo

Kigiri

owe

25. ka'ariba

owe

Ka'ariba

owe 
Songs of the Empty Place

1. Boy, you have ascended in your aeroplane

2. But you didn't tell me

3. Boy, we heard your aeroplane hum as it flew away

4. You wanted to tell me but you didn't

5. You put on your shoes and embarked

6. But to me you said nothing

7. You wanted to tell me, but you could not

8. You put on your white shirt and embarked

9. But you did not tell me

10. You put on your shirt, white as a cockatoo, and left

11. But you didn't tell me before you left

12. You pierced the clouds as you flew away

13. You wanted to tell me but you couldn't

14. I am the mother of the widow's kamora necklace

15. You didn't tell me

16. I am the mother of the kamora wrist band

17. You should have told me before you left

18. You took your two suitcases

19. You wanted to tell me but you couldn't

20. I am the mother of the widow's kamora

21. You didn't tell me before you left

22. The Orodobo clan woman, Gebo

23. Yaroge

24. The So'onedobo man, Kigiri

25. Ka'ariba 


\section{Sago Song 6}

\section{Singer: Kunuhuaka (with Siyame). Recorded 23 March 1988 at Hegeso village.}

This is another song addressing the sun maiden. This time, the singer, Kunuhuaka thinks about her eldest son, Bebe, who is assigned to a patrol boat with the Papua New Guinea Defence Force at Lombrum Patrol Base in Manus Province. She thinks of the sun shining off the guns on his ship and the ship's prow, even as it shines over Kunuhuaka's head while she is working. (See Weiner 1991:128-34; Figure 3 in this volume is a music transcription of lines 10-15.) J J online example 6.

1. humotorohahaibi weya'a

to break through comes

$\begin{array}{ll}\text { 2. } n a^{\prime} a & \text { ibiba'ae } \\ \text { you } & \text { is }\end{array}$

3. eye

eye

4. iri fagi si'abi weya'a

tree branches to search for comes

5. ne ibiba'ae

you is

6. eye

eye

7. ira so'oboro sebe weya'a

tree canopy search for comes

8. na'a ibiba'ae

you is

9. eye

eye

10. humeseseregaibi

weya'a

to shine

comes 
Songs of the Empty Place

11. ne ibiba'ae
you is

12. eye

eye

13. kui gaboba'ae foraye weya'a sago base-is break through comes

14. na'a ibiba'ae

you is

15. eye

eye

16. $\tilde{u} g i$ abotu'u kama'uri meya'a

breadfruit abotu'u top not yet

17. na'a ibiba'ae

you is

18. eye

eye

19. humeseseregaibi

weya'a

to shine

comes

20. na'a ibiba'ae

you is

21. eye

eye

22. kaubi weya'a

region comes

23. ne ibiba'ae

you is

24. eye

eye

25. eresaibi

weya'a

to look after

comes 
26. $n a^{\prime} a$ ibiba'ae

you

is

27. eye

eye

28. humotorohahaibi

weya'a

to break through

comes

29. ne

ibiba'ae

you

is

30. eye

eye

31. ira

so'oboro sebe

weya'a

tree

canopy

search for

comes

32. $n a^{\prime} a$

ibiba'ae

you

is

33. eye

eye

34. kui gaboba'a

kamu'uri

meya'a

sago

base-is

top

not yet

35. ne

ibiba'ae

you

is

36. eye

eye

37. sibi

arori

hiba'ane

$u b a^{\prime} a$

ship

prow

to embark

gone

38. $n a^{\prime} a$

ibiba'ae

you

is

39. eye

eye

40. gagaruri hiba'ane uba'a

to carry to embark gone 

41. na'a ibiba'ae
you is

42. eye

eye

\begin{tabular}{|c|c|c|}
\hline $\begin{array}{l}\text { 43. } a w a^{\prime} a \\
\text { sky }\end{array}$ & $\begin{array}{l}\text { bareri } \\
\text { vessel }\end{array}$ & $\begin{array}{l}\text { hiba'ane } \\
\text { to embark }\end{array}$ \\
\hline
\end{tabular}

44. ne ibiba'ae
you is

45. eye

eye

46. borowame

humogore'ane uba'ae

aquatic bird

to scatter gone

47. na'a ibiba'ae

you is

48. eye

eye

49. bagua

aquatic bird

humogoreye uba'a

to scatter gone

50. na'a ibiba'ae

you is

51. eye

eye

52. $e$

kabo sere-o

eh girl sun-o

53. na'abo dibu-o

to you I speak

54. eye

eye

55. e

kabo wãga-o

eh girl Clear-oh 
56. nebo dibu-o

you alone I speak

57. eye

eye

58. $e$

kabo yuri-o

eh girl Yuri-oh

59. na'abo iba'ae

to you is

60. eye

eye

1. You break through the clouds as you come

2. It is you

3. eye

4. You peek through the tree branches as you come

5. It is you

6. eye

7. You break through the tree canopy as you come

8. It is you

9. eye

10. You shine as you come

11. It is you

12. eye

13. You break through the sago palms as you come

14. It is you

15. eye

16. Don't peek through the top of the abotu'u breadfruit yet

17. It is you

18. eye

19. You shine as you come 
Songs of the Empty Place

20. It is you

21. eye

22. You look out over the whole land as you come

23. It is you

24. eye

25. You watch over the whole land as you come

26. It is you

27. eye

28. You break through the clouds as you come

29. It is you

30. eye

31. You peek through the top branches as you come

32. It is you

33. eye

34. Don't you light up the sago palms yet

35. It is you

36. eye

37. You light up the prow of his departing ship

38. It is you

39. eye

40. You light up the guns carried by his departing ship

41. It is you

42. eye

43. You light up the aeroplane as he embarked and left

44. It is you

45. eye

46. You cause the egrets to scatter over the Lake

47. It is you

48. eye

49. You cause the bagua birds to scatter over the Lake 
50. It is you

51. eye

52. Oh, Miss Daytime

53. It is to you I am speaking

54. eye

55. Oh Miss Clear Light

56. To you alone I speak

57. eye

58. Oh, Miss Yuri

59. It is to you I speak

60. eye

\section{Sago Song 7}

Singer: Kunuhuaka (with Siyame). Recorded 23 March 1988 at Hegeso village.

Bebe's army uniforms, washed and hanging out to dry, remind Kunuhuaka of the leaf of the stinging nettle. She sings of these uniforms, and Bebe's hat, and rifle: 'are these things sufficient to replace your brothers and other relatives with whom you no longer live? Will they protect you as well as these relatives do?' (See Weiner 1991:134-38.) J online example 7.

$\begin{array}{llll}\begin{array}{l}\text { 1. yengi } \\ \text { nettles }\end{array} & \begin{array}{l}\text { banima } \\ \text { banima }\end{array} & \begin{array}{l}\text { ba } \\ \text { that }\end{array} \\ \text { 2. } \begin{array}{l}\text { ba'a } \\ \text { boy }\end{array} & \begin{array}{l}\text { na'a } \\ \text { your }\end{array} & \begin{array}{l}\text { hame } \\ \text { brother }\end{array} & \begin{array}{l}\text { wae } \\ \text { not }\end{array}\end{array}$

3. eye

eye

$\begin{array}{lll}\text { 4. yengi } & \text { boro } & \text { ba } \\ \text { nettles } & \text { boro } & \text { that }\end{array}$




$\begin{array}{llll}\text { 5. } & \begin{array}{lll}a^{\prime} a \\ \text { boy }\end{array} & \text { brother } & \text { wame }\end{array}$

6. eye

eye

7. yengi gugabe ba nettles flying fox that

8. $b a^{\prime} a$ boy

$\begin{array}{lll}n a^{\prime} a & \text { base } & \text { wae } \\ \text { your } & \text { sister's husband } & \text { not }\end{array}$

9. eye

eye

10. ganuga hat

boge

$a b a$

ba

club

father

that

11. $b a^{\prime} a$

$n a^{\prime} a$

kabe

wame wae

boy

your

man

brother

not

12. eye

eye

13. ganuga hat

boge

$a b a$

$b a$

$b a^{\prime} a$

club

father

that

14. $b a^{\prime} a$

$n a^{\prime} a$

your

base

wae

boy

sister's husband

not

15. eye

eye

16. $b i^{\prime} a$

fore

$a b a$

$b a$

rifle

large

father

that

17. $b a^{\prime} a$

$n a^{\prime} a$

$a b a$

wae

boy

your

father

not

18. eye

eye

19. bare

sibi

ba

canoe

ship

that 


\begin{tabular}{|c|c|c|}
\hline $\begin{array}{l}\text { 20. } b a^{\prime} a \\
\text { boy }\end{array}$ & $\begin{array}{l}n a^{\prime} a \\
\text { your }\end{array}$ & $\begin{array}{l}\text { hua } \\
\text { mother }\end{array}$ \\
\hline
\end{tabular}

21. eye

eye

22. sabe

sode

knife

sheath

23. $b a^{\prime} a$

boy

na'a

ana

wae

your

sister

not

24. eye

eye

25. oro

yerebi

$b a^{\prime} a$

terewaro

bamboo

yerebi

boy

Terewaro

26. $n a^{\prime} a b o$

dibu-o

to you

I speak

27. eye

eye

28. kui

kenege $\quad b a^{\prime} a$

bebe

sago

mid-rib

boy

Bebe

29. $n a^{\prime} a b o$

dibu-o

to you

I speak

30. eye

eye

1. Your banima nettles hanging there

2. It's not your brother

3. eye

4. Your boro nettles there

5. It's not your brother

6. eye

7. Your nettles hanging like flying foxes 
Songs of the Empty Place

8. It's not your brother-in-law

9. eye

10. The owner of the club-shaped army hat

11. It's not your Mister brother

12. eye

13. The owner of the club-shaped army hat

14. It's not your sister's husband

15. eye

16. The owner of your big rifle

17. It's not your father

18. eye

19. The sea going ship

20. It's not your mother

21. eye

22. Your bayonet sheath

23. It's not your sister

24. eye

25. The yerebi bamboo clan boy Terewaro

26. It is to you I am speaking

27. eye

28. The Sago mid-rib clan boy Bebe

29. It is you I am speaking

30. eye 


\section{Men's Songs (Sorohabora)}

\section{Men's Song 1}

\section{Singers: Memene and Abeabo. Recorded 6 January 1985 at Hegeso village.}

This song depicts the competition between the men of Hegeso and Barutage villages as they both prepare for a pig-kill. The subject of the song is revealed towards the end of it, in a section called dawadobora. The singing of the word dawa or dawabo is frequent at this point, as in verse four of this song. (See Weiner 1991:159-62.)

1. $b a^{\prime} a \quad n a^{\prime} a \quad \tilde{e}$ siri hubu kegere boy your garden large struck disparage

dibihamone

do not speak (disparage)

$\begin{array}{lllllll}b a^{\prime} a & n a^{\prime} a & a & \text { siri } & \text { hare } & \text { tegebu } & \text { kegere } \\ \text { boy } & \text { your } & \text { house } & \text { large } & \text { doing } & \text { built } & \text { disparage }\end{array}$

dibihamone

do not speak (disparage)

2. $b a^{\prime} a$ na'a kuru kirari mabo kegere

boy your black rope taken disparage

dibihamone

do not say (disparage)

$\begin{array}{llllll}b a^{\prime} a & n a^{\prime} a & y a^{\prime} o & \text { kirari } & \text { mabo } & \text { kegere } \\ \text { boy } & \text { your } & \text { many-coloured } & \text { rope } & \text { taken } & \text { disparage }\end{array}$

dia óoyo'o

saying do not go

3. $b a^{\prime} a$ na'a siri $\quad \tilde{e}$ hubu kegere

boy your garden large planted disparage

dia óoyo'o

saying do not go 
Songs of the Empty Place

$\begin{array}{lllll}b a^{\prime} a & n a^{\prime} a & \text { musu'uni } & \text { kamabo } & \text { kegere } \\ \text { boy } & \text { your } & \text { smoke } & \text { rising } & \text { disparage }\end{array}$

dibiha'oyo'o

do not keep saying

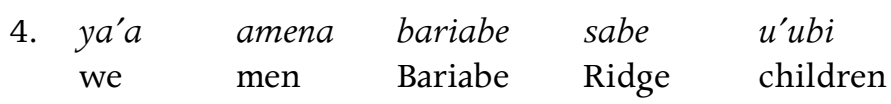

dawabo

dawabo

ya'a amena ibu faya'a wabo

we men river Faya'a coming

dawabo

dawabo

$\begin{array}{lllll}\text { 5. yiya } & \text { amena } & \text { ibu } & \text { faya'a } & \text { kege } \\ \text { we } & \text { men } & \text { river } & \text { Faya'a } & \text { bank }\end{array}$

dawabo

dawabo

yiya amena yagenebo sabe u'ubi

we men Yagenebo Ridge children

ibu dawabo

river Dawabo

1. Boy, you have made a big garden

But don't disparage me

Boy, you have built a great house

But don't denigrate me

2. You hold the rope of the black pig

But don't disparage me

You hold the rope of the piebald pig

But don't speak disrespectfully of me

3. You clear the bush to make a big garden

But don't hold me cheaply

The smoke rises from your new garden

But don't disparage me 
4. We are the men of Bariabe Sabe

Dawabo

We are the men of the Faya'a Creek flowing

Dawabo

5. We are the men of the banks of the Faya'a Creek

Dawabo

We are the men of Yagenebo Sabe

Ibu Dawabo

\section{Men's Song 2}

\section{Singers: Memene and Abeabo. Recorded 6 January 1985 at Hegeso village.}

Memene, a man of Hegeso village, learned this song, which commemorates a Wasemi man, when he was visiting at Lake Kutubu. (See Weiner 1991:83, 104.) J online example 8 .

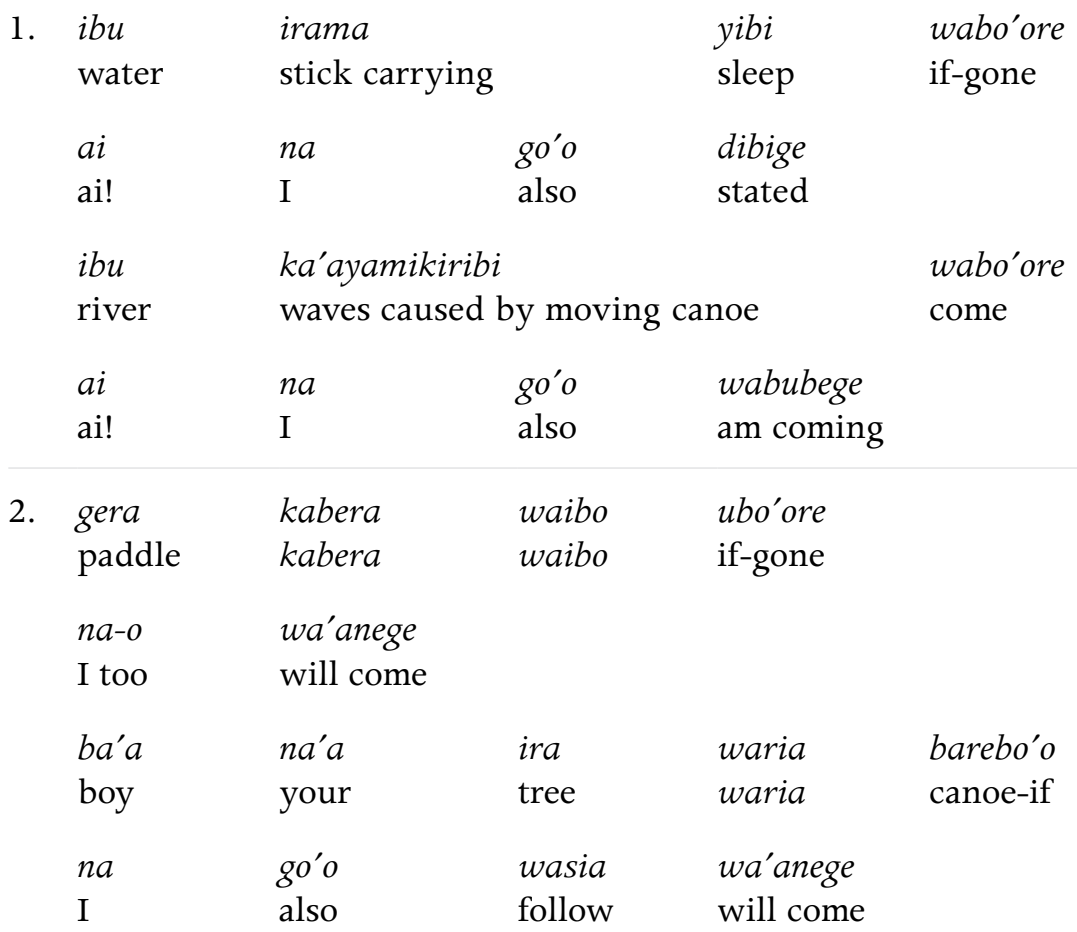




\begin{tabular}{|c|c|c|c|c|}
\hline $\begin{array}{l}\text { 3. } b a^{\prime} a \\
\text { boy }\end{array}$ & $\begin{array}{l}n a^{\prime} a \\
\text { your }\end{array}$ & $\begin{array}{l}\text { gesa } \\
\text { dog }\end{array}$ & $\begin{array}{l}\text { momabo } \\
\text { Momabo }\end{array}$ & $\begin{array}{l}\text { ubo'ore } \\
\text { if-gone }\end{array}$ \\
\hline $\begin{array}{l}n a \\
\mathrm{I}\end{array}$ & $\begin{array}{l}g o^{\prime} o \\
\text { also }\end{array}$ & $\begin{array}{l}\text { wa'agerege } \\
\text { will come }\end{array}$ & & \\
\hline $\begin{array}{l}b a^{\prime} a \\
\text { boy }\end{array}$ & $\begin{array}{l}n a^{\prime} a \\
\text { your }\end{array}$ & $\begin{array}{l}\text { gesa } \\
\text { dog }\end{array}$ & $\begin{array}{l}\text { sawabo } \\
\text { Sawabo }\end{array}$ & $\begin{array}{l}\text { ubo'ore } \\
\text { if-gone }\end{array}$ \\
\hline $\begin{array}{l}\text { na-o } \\
\text { I too }\end{array}$ & $\begin{array}{l}\text { wa'anege } \\
\text { will come }\end{array}$ & & & \\
\hline
\end{tabular}

$\begin{array}{lll}\text { 4. } \begin{array}{ll}\text { orodobo } \\ \text { Orodobo }\end{array} & \begin{array}{l}\text { kabe } \\ \text { man }\end{array} & \begin{array}{l}\text { soaeyamo } \\ \text { Soaeya }\end{array} \\ \begin{array}{l}\text { kabe } \\ \text { man }\end{array} & \begin{array}{l}\text { Kamuna } \\ \text { Kamuna }\end{array} \\ \begin{array}{l}\text { orodobo } \\ \text { Orodobo }\end{array} & \text { mabe } & \begin{array}{l}\text { kamunamo } \\ \text { Kan }\end{array} \\ \begin{array}{l}\text { dawabo } \\ \text { dawabo }\end{array} & & \\ \end{array}$

$\begin{array}{lllll}\text { 5. } \begin{array}{lll}\text { ira } \\ \text { tree }\end{array} & \begin{array}{l}\text { hagenamo } \\ \text { Gnetum sp. }\end{array} & \begin{array}{l}\text { dobo } \\ \text { clan }\end{array} & \begin{array}{l}\text { ba'a } \\ \text { boy }\end{array} & \begin{array}{l}\text { faimano } \\ \text { Faimano }\end{array} \\ \begin{array}{l}\text { kabe } \\ \text { man }\end{array} & \begin{array}{l}\text { Seimano } \\ \text { Seimano }\end{array} & & & \\ \text { ira } & \text { hagenamo } & \text { dobo } & \text { ba'a } & \text { faimano } \\ \text { tree } & \text { Gnetum sp. } & \text { clan } & \text { boy } & \text { Faimano } \\ \text { kabe } & \text { Seimano } & & & \\ \text { man } & \text { Seimano } & & & \end{array}$

1. The men who sleep near the fast flowing river
$\mathrm{Ai}$, I too am coming

The waves caused by the canoe in motion

Ai, I too am coming

2. The kabera tree paddle which you used

I too am coming

Boy, your waria tree canoe 
3. If you take your dog Moma

I too want to come

If you take your dog Sawabo

I too will come

4. The son of the Orodobo man Soaeya

His son, Kamuna

The Orodobo man Kamuna

Dawabo

5. The clan of the hagenamo, the boy Faimano

His son, Seimano

The Sanimahia clan, the boy Faimano

His son, Seimano

\section{Men's Song 3}

\section{Singers: Memene and Abeabo. Recorded 6 January 1985 at Hegeso village.}

This song commemorates Dosabo, a man of Damayu village who was suspected of being a sorcerer, an accusation he denied before his death. The song speaks of a man who claimed never to have been taught these sorcery spells by the deceased before he died. (See Weiner 1991:47, 108-9, 171-75, 176-81 (music transcription); 2001:26; Figure 5 in this volume is a music transcription of verse 2.) J J online example 9.

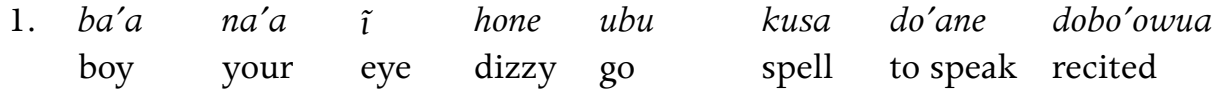

dia ubo'oriye

said did not go

\footnotetext{
1 The -o'oriye ending in dia ubo'oriye and, in the following verse, dobo'oriye indicates that the speaker learned of the action through indirect evidence or evidence no longer present, e.g. someone else informed him of an action that he himself lacks evidence of. In this case, he is singing, 'I have no evidence that you spoke to me about these spells before you died.'
} 
Songs of the Empty Place

$\begin{array}{lllll}\text { ba'a } & n a^{\prime} a & \text { kigi wara'obo } & \text { kusa do'ane dobo'owua } \\ \text { boy } & \text { your bone weakness } & \text { spell to speak recited }\end{array}$

2. ba'a na'a i hone ubu kusa do'ane dobo'owa boy your eye dizzy go spell to speak recited

dobo'oriye

did not tell

$\begin{array}{lllllll}\text { ba'a } & n a^{\prime} a & y a & \text { karo } & \text { kusa } & \text { do'ane } & \text { dobo'owua } \\ \text { boy } & \text { your } & \text { arm } & \text { upper } & \text { spell } & \text { to speak } & \text { recited }\end{array}$

dia ubo'oriye

saying did not go

3. $b a^{\prime a} n a^{\prime a}$ kõ tugame kusa do'ane dobo'owa'a

boy your cordyline tugame spell to speak recited

dobo'oriye

did not tell

ba'a na'a ya karo kusa do'ane dobo'owa

boy your arm upper spell to speak recited

dia ubo'oriye

saying did not go

4. yia amena bi'a huba

we men black palm huba

ibudawabo

ibudawabo

yiya amena gesa moma

we men dog Moma

dawabo

dawabo

5. momahu'u isa'ibu

Momahu'u Isa'ibu

kabe bo

man Bo 
momahu'u kabe isa'ibu

Momahu'u man Isa'ibu

kabe dosabo

man Dosabo

1. Boy, your sleep-causing spell you used to recite You never told me before you left

Boy, your weakness-causing spell you used to recite You never instructed me before you left

2. Boy, your sleep-causing spell you used to recite You never told me before you left

Boy, your wasting sickness spell you used to know You failed to pass it on to me before you left

3. Boy, your spell of assassination you used to recite You never told me

Boy, your wasting sickness spell you used to cast You never instructed me

4. We are the men of the Huba Black Palm Ibu Dawabo

We are the men of the dog Moma

Dawabo

5. The Momahu'u man Isa'ibu

His son, Bo

The Momahu'u man Isa'ibu His son, Dosabo 


\section{Men's Song 4}

\section{Singers: Memene and Abeabo. Recorded 1 January 1985 at Hegeso village.}

This is a song about the tree kangaroo as it wanders through the forest. As with other marsupials and the cassowary, it seeks the fruit of the bai tree (a Ficus species), and the shoots of young bamboo. (See Weiner 1991:112-14.)

$\begin{array}{lll}\text { 1. kagi } & \begin{array}{l}\text { aũwa } \\ \text { softly }\end{array} & \begin{array}{l}\text { hubiwe'iya'are } \\ \text { falling-come }\end{array} \\ \text { ba'a } & n a^{\prime} a & \begin{array}{l}\text { igebe } \\ \text { is it? }\end{array} \\ \text { boy } & \text { you } & \text { hubiwe'iya'are } \\ \text { kunu } & \text { kunuga } & \text { rattling-come } \\ \text { palm wood } & \text { floor } & \text { igebe } \\ \text { ba'a } & n a^{\prime} a & \text { is it? }\end{array}$

2. kana togebiwe'iya'are

stone overturn-come

$\begin{array}{lllll}\begin{array}{l}b a^{\prime} a \\ \text { boy }\end{array} & \begin{array}{l}n a^{\prime} a \\ \text { you }\end{array} & \begin{array}{l}\text { iyo'oge } \\ \text { is }\end{array} & & \\ \text { ira } & \text { waru } & \text { sina } & \text { irari } & \text { hubiwe'iya'are } \\ \text { tree } & \text { waru } & \text { shoots } & \text { dew } & \text { brushing-come } \\ \text { ba'a } & n a^{\prime} a & \text { iyo'oge } & & \\ \text { boy } & \text { you } & \text { is } & & \end{array}$

3. kunuga hubiwei'iya'are

floor striking-come

$\begin{array}{lll}b a^{\prime} a & n a^{\prime} a & \text { iyo'oge } \\ \text { boy } & \text { you } & \text { is }\end{array}$

2 Hubiwe'iya'are: the ending -iya'are is a nominalised form of the -iyo'o ending which indicates knowledge gained of a past action from present, sensible evidence (Weiner 1991:115, n. 4).

3 -iyo'oge: 'was that you? (based on the evidence I see myself as I walk through the bush).' 


$\begin{array}{lllll}\text { ira } & \text { bai } & \text { sina } & \text { irari } & \text { hubiwe'iya'are } \\ \text { tree } & \text { bai } & \text { saplings } & \text { dew } & \text { brushing-come }\end{array}$

ba'a na'a iyo'oge

boy you is

4. oro sina ineri hubiwe'iya'are

bamboo shoots dew brushing-come

ba'a na'a iyo'oge

boy you is

$\begin{array}{llll}\text { ira baĩ } & \text { sina } & \text { ireri } & \text { hubiwe'iya'are }\end{array}$

ba'a na'a iyo'oge

boy you is

5. duma haro sese sone

mountain climbing marsupial Sone

dawabo

dawabo

$\begin{array}{llll}\text { duma } & \text { hau } & \text { sese } & \text { sawa } \\ \text { mountain } & \text { side } & \text { marsupial } & \text { Sawa }\end{array}$

ibudawabo

ibudawabo

6. duma oro sese sawa

mountain top marsupial Sawa

dawabo

dawabo

$\begin{array}{llll}\text { duma } & \text { fai } & \text { sese } & \text { sone } \\ \text { mountain } & \text { side } & \text { marsupial } & \text { Sone }\end{array}$

dawabo

dawabo 
1. The sound of rain falling softly while someone approaches Boy, is that you?

A sound like palm wood floor beams rattling as someone comes Boy, could that be you?

2. You overturn the stones as you approach Boy, is that you?

Your legs are wet like dew on the waru tree saplings

Boy, could that be you?

3. The sound of rattling as someone approaches Boy, is that you?

Your legs are as wet as the bai saplings covered with dew Boy, could that be you?

4. You brush the dew off the bamboo shoots as you come Boy, is that you?

You are wet from the dew of the baĩ tree saplings Boy, could that be you?

5. Along the hillside, the tree kangaroo named Sone walks Dawabo

Along the side of the mountain, the tree kangaroo named Sawa wanders Ibu Dawabo

6. At the crest of the mountain, Sawa wanders Dawabo

Along the mountain sides, Sone travels Dawabo 


\section{Men's Song 5}

\section{Singers: Memene and Abeabo. Recorded 1 January 1985 at Hegeso village.}

This song commemorates Mare of the Fo'omahu'u clan of Hegeso. The theme is a common one: a dead man can no longer go hunting. Men's songs 5 and 9 are alike in their use of the negative command form in the second line refrain. (See Weiner 1991:46, 110-12; 2001:25-26.)

1. se

marsupial

sebe'o'oyo'o

do not search

$\begin{array}{llll}\begin{array}{l}\text { sese } \\ \text { marsupial }\end{array} & \begin{array}{l}\text { baro } \\ \text { baro }\end{array} & \begin{array}{l}\text { yibu } \\ \text { sleep }\end{array} & \begin{array}{l}\text { kunuga } \\ \text { cave }\end{array} \\ \text { sia' } & \begin{array}{l}\text { o'oyo'o } \\ \text { do not go }\end{array} & & \\ \text { search } & \text { do } & \end{array}$

2. sigina

cassowary

daba

large

yibu

sleep

kunuga

uaha

go-live

yiboba'ae

sleeps

sese

marsupial

budu

black

yibu

sleep

kunuga

cave

bereboba'ae

is lost

3. ya

bird

dabura

red

$\begin{array}{ll}\text { hua } & \text { yibu } \\ \text { mother } & \text { sleep }\end{array}$

kunuga

cave

sia

ubihamone

search

do not keep going

ya

gibi

hua

bush fowl

mother

kunuga

bird

$o^{\prime}$ oyo'o

sia

do not go 


$\begin{array}{llll}\begin{array}{l}\text { kuiyare } \\ \text { python }\end{array} & \begin{array}{l}\text { yibu } \\ \text { sleep }\end{array} & \begin{array}{l}\text { kunuga } \\ \text { cave }\end{array} & \\ \text { sia } & \begin{array}{l}\text { o'oyo'o } \\ \text { do not go }\end{array} & & \\ \text { tuba } & \text { budu } & \text { yibu } & \text { kunuga } \\ \text { tree kangaroo } & \text { black } & \text { sleep } & \text { cave } \\ \text { sebe'o'oyo'o } & & & \\ \text { do not search } & & & \end{array}$

$\begin{array}{llll}\begin{array}{l}\text { yiya } \\ \text { we }\end{array} & \begin{array}{l}\text { amena } \\ \text { men }\end{array} & \begin{array}{l}\text { ira } \\ \text { tree }\end{array} & \begin{array}{l}\text { ma'aru } \\ \text { ma'aru }\end{array} \\ \begin{array}{l}\text { dawabo } \\ \text { dawabo }\end{array} & & & \\ \text { yiya } & \text { amena } & \text { ira } & \text { banamo } \\ \text { we } & \text { men } & \text { tree } & \text { banamo } \\ \text { dawabo } & & & \\ \text { dawabo } & & & \\ \text { ira } & & & \\ \text { tree } & \text { ma'arudobo } & \text { meremo } & \\ \text { ba'a } & \text { ma'aru clan } & \text { Mere's } & \\ \text { boy } & \text { Mare } & & \\ \text { ira } & \text { Mare } & & \text { bamo } \\ \text { tree } & \text { ma'arudobo } & \text { ba'a } & \text { mege } \\ \text { dawabo } & \text { ma'aru clan } & \text { boy } & \text { only } \\ \text { dawabo } & & & \end{array}$

1. The duma marsupial which sleeps in the limestone caves Do not search for it

The baro marsupial which sleeps in the caves Do not attempt to seek it

2. The large cassowary which sleeps in the caves of stone He has gone away 
The black marsupial of the stone caves

He too is lost

3. The bush fowl mother who sleeps in the cave

Do not go looking for her

The red bush fowl mother who sleeps in the cave

Do not seek her

4. The python who sleeps in the stone cave

Do not go looking for it

The black tree kangaroo who sleeps in the cave

Do not try and find it

5. We are the men of $m a^{\prime} a r u$ tree clan

Dawabo

We are the men of the banamo tree clan

Dawabo

6. The $m a^{\prime} a r u$ tree clan man, Mere

His son, Mare

The $m a^{\prime}$ aru tree clan, this only boy

Dawabo

\section{Men's Song 6}

\section{Singers: Wa'o and Midibaru. Recorded 6 January 1985 at Hegeso village.}

If in a dream, a man sees a large tree such as a furubu falling down, it portends the death of a headman. This song makes use of that common image to commemorate the death of the Hegeso headman Iraharabo, of the Tirifadobo (Ma'arudobo) clan. (See Weiner 1998a:339-40.)

$\begin{array}{ll}\text { 1. } & \text { furabu derare } \\ \text { tree } & \text { furabu that }\end{array}$

forabibi'ae

fallen 
Songs of the Empty Place

ira furabu derare
tree furabu that
formabibi'ae
long fallen
2. ba'a na'a ao dumaro'o
boy your bush mountain
aodoboba'ae
bush covered

\begin{tabular}{|c|c|c|c|}
\hline $\begin{array}{l}b a^{\prime} a \\
\text { boy }\end{array}$ & $\begin{array}{l}n a^{\prime} a \\
\text { your }\end{array}$ & $\begin{array}{l}k \tilde{o} \\
\text { cordyline }\end{array}$ & $\begin{array}{l}\text { tegeri } \\
\text { tegeri }\end{array}$ \\
\hline
\end{tabular}
foraboba'ae
hand broken

$\begin{array}{lllll}\text { 3. } \begin{array}{ll}\text { na } a \\ \text { boy }\end{array} \text { your } & \text { ira } & \text { furabu derare } \\ & \text { tree furabu that }\end{array}$

forabi'ae

fallen

\begin{tabular}{|c|c|c|}
\hline $\begin{array}{l}b a^{\prime} a \\
\text { boy }\end{array}$ & $\begin{array}{l}n a^{\prime} a \\
\text { your }\end{array}$ & $\begin{array}{l}\text { kegebe } \\
\text { vine }\end{array}$ \\
\hline
\end{tabular}

forabo'owa'ae

cut

$\begin{array}{lllll}\text { 4. } \begin{array}{l}\text { wa'ari } \\ \text { palm }\end{array} & \begin{array}{l}\text { hubobi dobo } \\ \text { hubobi clan }\end{array} & \begin{array}{l}\text { kabe } \\ \text { man }\end{array} & \begin{array}{l}\text { degayomore } \\ \text { Degayo }\end{array} \\ \text { kabe } & \text { harabi } & & & \\ \text { man } & \text { Harabi } & & & \\ \text { wa'ari } & \text { hububi dobo } & \text { kabe } & \text { mege } & \text { bamore } \\ \text { palm } & \text { hubobi clan } & \text { man } & \text { only that }\end{array}$

$\begin{array}{llll}\text { 5. } \begin{array}{lll}\text { yo } \\ \text { his }\end{array} & \begin{array}{l}\text { hua } \\ \text { mother woman }\end{array} & \begin{array}{l}\text { mege } \\ \text { only }\end{array} & \begin{array}{l}\text { bamo } \\ \text { that }\end{array} \\ \text { kabe } & \begin{array}{l}\text { Iraharabo } \\ \text { man }\end{array} & \text { Iraharabo } & \\ \end{array}$




$\begin{array}{llllll}\begin{array}{l}\text { bi'a } \\ \text { black palm }\end{array} & \begin{array}{l}\text { huba } \\ \text { huba }\end{array} & \begin{array}{l}\text { dobo } \\ \text { clan }\end{array} & \begin{array}{l}k a \\ \text { woman }\end{array} & \begin{array}{l}\text { mege only } \\ \text { ond }\end{array} & \begin{array}{l}\text { mame } \\ \text { that }\end{array} \\ b a^{\prime} a & \begin{array}{l}\text { Harabi } \\ \text { boy }\end{array} & & & \\ \text { Harabi } & & & \end{array}$

1. The tall furabu tree fallen

The tall furabo tree long fallen

2. Your tree covered mountain Covered with bush

Your tegeri cordyline seeds broken off

3. Your tall furabu tree fallen

Your $a b u$ vine long cut down

4. He of the hubobi palm clan Degayo his son Harabi That sole man of the hubobi palm clan the man Iraharabo

5. That sole woman, his mother her son Iraharabo That only woman of the huba black-palm clan Her son, Harabi 


\section{Men's Song 7}

\section{Singers: Wa'o and Midibaru. Recorded 6 January 1985 at Hegeso village.}

This song commemorates Sese, a man of Hegeso. The imagery is a very common one: a man is dead, and the forest has reclaimed those places which he used to frequent and upon which he left the imprint of human activity. The creeks referred to are at Ayamo in Banimahu'u clan territory. (See Weiner 1991:59, 101-2.) J online example 8.

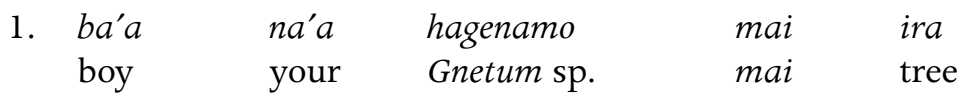

aodoba'aye

let bush covered

$\begin{array}{lllll}b a^{\prime} a & n a^{\prime} a & m a i & \text { ira } & \text { bare } \\ \text { boy } & \text { your } & m a i & \text { tree } & \text { that }\end{array}$

kigiba'aye

let strong bush

2. $b a^{\prime a}$ na'a ibu barua ga habo duma

boy your creek Barua source flow into mountain

aodoba'aye

let bush covered

ba'a na'a ao iburo'o

boy your bush creek

kigiba'aye

let strong bush

3. ba'a na'a da'ari fai dumaro'o

boy your stone side mountain

abumaba'aye

let bank ground crumble

\begin{tabular}{|c|c|c|}
\hline $\begin{array}{l}b a^{\prime} a \\
\text { boy }\end{array}$ & $\begin{array}{l}\text { na'a } \\
\text { your }\end{array}$ & $\begin{array}{l}\text { aodumaro'o } \\
\text { bush covered mountain }\end{array}$ \\
\hline & waba'aye & \\
\hline
\end{tabular}




$\begin{array}{lllll}\text { 4. } \begin{array}{l}\text { ya } \\ \text { bird }\end{array} & \begin{array}{l}\text { banima } \\ \text { banima }\end{array} & \begin{array}{l}\text { dobo clan } \\ \text { mabe }\end{array} & \begin{array}{l}\text { irihaimabo } \\ \text { Irihaimabo }\end{array} \\ \text { kabe } & \text { tiraru } & & & \\ \text { man } & \text { Tiraru } & & & \\ \text { ya } & \text { banima dobo } & \text { kabe } & \text { irihaimabo } \\ \text { bird } & \text { banima clan } & \text { man } & \text { Irihaimabo }\end{array}$

ibudawabo

ibudawabo

5. kibudobo ka yamo

Kibudobo woman Ya

kabe kunugamena

man Kunugamena

kibudobo ka mege bamo

Kibudobo woman only that

kabe Sese

man Sese

1. Boy, your mai hagenamo tree

Has been covered over with bush

Boy, that hagenamo tree of yours

Has been reclaimed by the forest

2. Boy, your Baruaga Creek flowing into the mountain

The bush has covered it over

Boy, your tiny creek

The forest has claimed it back

3. Boy, your stone banked mountain creek

The ground crumbles from its banks

Boy, your mountain place in the forest

Let the trees take it back

4. The clan of the banima bird, the man Irihaimabo

His son, Tiraru

The clan of the banima bird, the man Irihaimabo

Ibu Dawabo 
5. The Kibudobo clan, the woman Ya Her son's hidden name, Kanugamena

The Kibudobo clan this only woman Her son Sese

\section{Men's Song 8}

\section{Singers: Wa'o and Midibaru. Recorded 6 January 1985 at Hegeso village.}

This song commemorates a man of the So'onedobo clan of Hegeso, Yabokigi. The dead man is likened to a bird who drops to earth with a broken wing. The Sulphur-crested Cockatoo is one of the main totems of the So' onedobo clan. The leaves of the so'one and furabu trees, the former a totem of the So'onedobo clan, the latter associated with headmen, are broken off by the flapping wings of birds; the leaves are the men of a clan as they die and drop off or are broken off. (See Weiner 1991:17-19, 94-95, 97, 171-75, 176-81 (music transcription).) J online example 9.

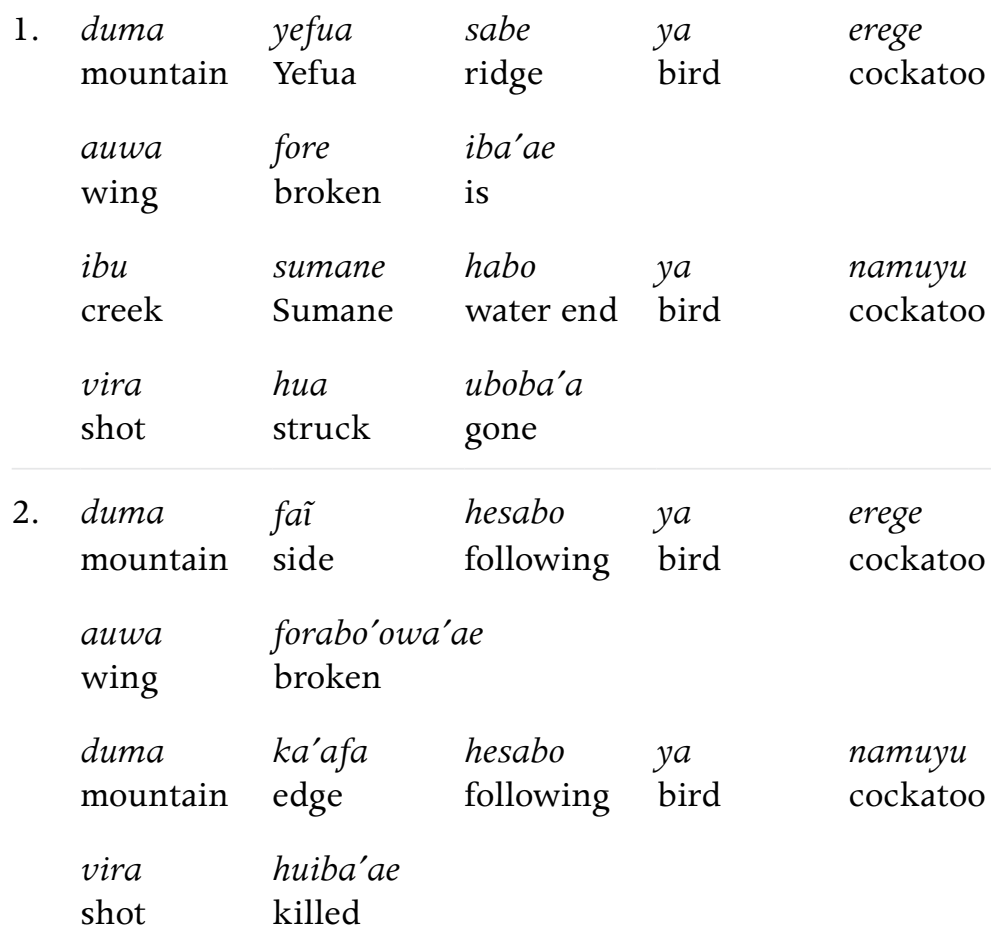




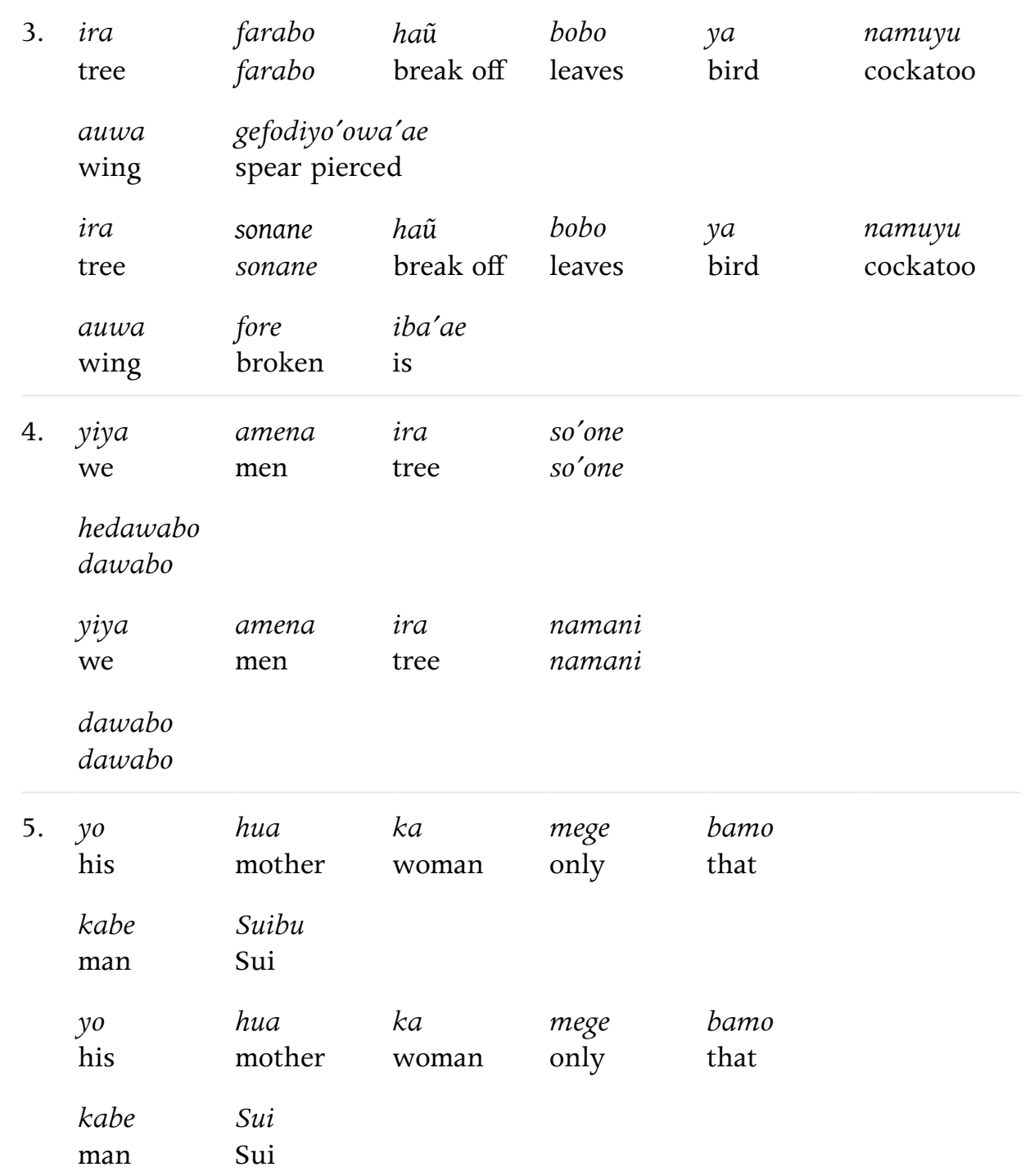

1. The ridge of Mt Yefua, the Sulphur-crested Cockatoo Its wing is broken

At Sumani Creek as it flows underground, the cockatoo Its wing is broken

2. Following the side of the mountain, the cockatoo Its wing broken 
Along the edge of the mountain's base, the cockatoo Arrow shot and killed

3. The cockatoo breaks off the leaves of the farabo tree as it flies Its wing broken

The leaves of the so'one tree, broken off by the cockatoo's flapping wings Its wing broken

4. We are the men of the so'one tree clan Ibu Dawabo

We are the men of the namani tree clan Dawabo

5. His mother, the only woman Her son, Sui His mother, the only women Her son, Sui

\section{Men's Song 9}

\section{Singers: Kora and Garibi. Recorded 6 January 1985 at Hegeso village.}

This song for Hibare, a So'onedobo man of Hegeso, appeared in abbreviated form in The Heart of the Pearl Shell (Weiner 1988a:284). A man moves from place to place during his life, and these places constitute a spatial record of his temporal life span. So too do the remembered bodies of discourse which were attributed to him during his life - such as myths. Insofar as speaking is a bodily activity, a person's utterances outline his or her body and give some clue as to its components, physical and social. In its illustrative use of discursive detotalisation, the following song indicates how literally the Foi are apt to consider that image. (See Weiner 1991:47, 162-64; 2001:26.) J J online example 8.

\begin{tabular}{|c|c|c|c|}
\hline $\begin{array}{l}\text { 1. } b a^{\prime} a \\
\text { boy }\end{array}$ & $\begin{array}{l}n a^{\prime} a \\
\text { your }\end{array}$ & $\begin{array}{l}\tilde{\imath} \\
\text { eye }\end{array}$ & $\begin{array}{l}\text { mano } \\
\text { small }\end{array}$ \\
\hline
\end{tabular}

dibiha'adiye

can not recite 


$\begin{array}{lllll}\begin{array}{l}b a^{\prime} a \\ \text { boy }\end{array} & \text { na'a } & \text { ya } & \text { karo } & \begin{array}{l}\text { tuniro'o } \\ \text { myth }\end{array} \\ \text { do'odiye } & & \text { arm } & \text { upper } & \\ \text { cannot say } & & & & \end{array}$

2. $b a^{\prime} a$

boy

na'a i

eye

mano

tuniro'o

dibihamone

do not recite

$\begin{array}{lllll}b a^{\prime} a & n a^{\prime} a & y a & \text { karo } & \text { tuniro'o } \\ \text { boy } & \text { your } & \text { arm } & \text { upper } & \text { myth }\end{array}$

dibihamone

do not recite

\begin{tabular}{|c|c|c|c|c|}
\hline $\begin{array}{l}b a^{\prime} a \\
\text { boy }\end{array}$ & $\begin{array}{l}n a^{\prime} a \\
\text { your }\end{array}$ & $\begin{array}{l}\tilde{\imath} \\
\text { eye }\end{array}$ & $\begin{array}{l}\text { mano } \\
\text { small }\end{array}$ & $\begin{array}{l}\text { tuniro'o } \\
\text { myth }\end{array}$ \\
\hline $\begin{array}{l}\text { dibih } \\
\text { do no }\end{array}$ & & & & \\
\hline $\begin{array}{l}b a^{\prime} a \\
\text { boy }\end{array}$ & $\begin{array}{l}\text { na'a } \\
\text { your }\end{array}$ & $\begin{array}{l}y a \\
\text { arm }\end{array}$ & $\begin{array}{l}\text { karo } \\
\text { upper }\end{array}$ & $\begin{array}{l}\text { tuniro'o } \\
\text { myth }\end{array}$ \\
\hline
\end{tabular}

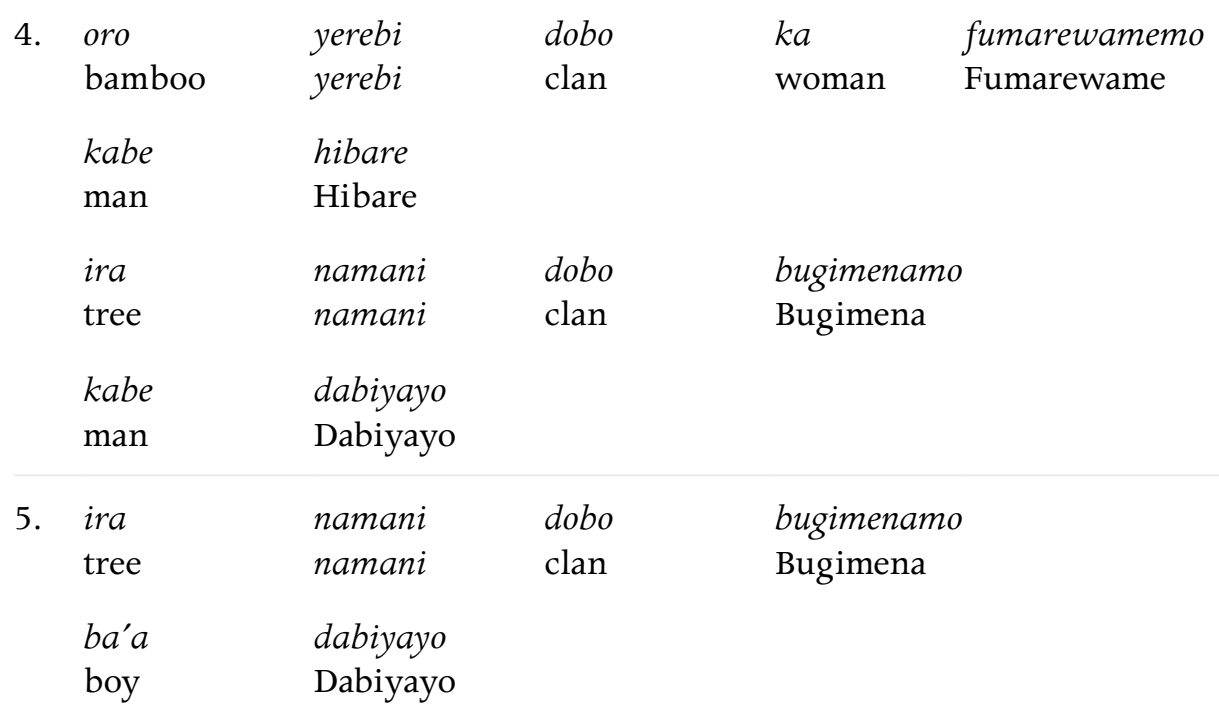


Songs of the Empty Place

$\begin{array}{lllll}\begin{array}{l}\text { oro } \\ \text { bamboo }\end{array} & \begin{array}{l}\text { yerebi } \\ \text { yerebi }\end{array} & \begin{array}{l}\text { dobo } \\ \text { clan }\end{array} & \begin{array}{l}\text { ka } \\ \text { woman }\end{array} & \begin{array}{l}\text { fumarewamemo } \\ \text { Fumarewame }\end{array} \\ \begin{array}{l}\text { ba'a } \\ \text { boy }\end{array} & \begin{array}{l}\text { Hibare } \\ \text { Hibare }\end{array} & & & \\ \end{array}$

1. Boy, your 'Little Eye' myth

You can no longer tell

Boy, your 'Upper Arm' myth

How can you tell it

2. Boy, your 'Little Eye' myth

Do not recite it

Boy, your 'Upper Arm' myth

Do not recite it

3. Boy, your 'Little Eye' myth

Do not recite it

Boy, your 'Upper Arm' myth

Do not recite it

4. The clan of the yerebi bamboo, the woman Fumaruwame

Her son, Hibare

The clan of the namani tree, the man Bugimena

His son, Dabiyayo

5. The namani tree clan, the man Bugimena

The boy Dabiyayo

The yerebi bamboo clan, the woman Fumaruwame

The boy Hibare

\section{Men's Song 10}

\section{Singers: Kora and Garibi. Recorded 6 January 1985 at Hegeso village.}

Cordyline, whether worn as a rear covering by men, or as shrubs planted around a house, is intimately associated indexically and metonymically with 
men. Hence, a broken cordyline shrub is an oft-used image for a dead man, as this memorial song for the Orodobo man Kawaru demonstrates. The shoots or regrowth which appear on cordyline and on the trees mentioned in the song are also likened to living, growing children, and are used in this song to depict the death of Kawaru. (See Weiner 1991:171-75, 176-81 (music transcription).) J online example 9.

1. $b a^{\prime} a$

$$
n a^{\prime} a
$$

$k \tilde{o}$

tegeri

ma'aya

dera

boy

your

cordyline tegeri

seeds

those

foraboba'ae

broken off

$\begin{array}{lllll}\begin{array}{l}\text { ba'a na'a } \\ \text { boy your }\end{array} & \begin{array}{l}\text { wagebo } \\ \text { cane }\end{array} & \begin{array}{l}\text { kegebe } \\ \text { vine }\end{array} & \begin{array}{l}\text { ma'aya } \\ \text { seeds }\end{array} & \begin{array}{l}\text { dera } \\ \text { those }\end{array} \\ \begin{array}{l}\text { debema } \\ \text { broken off-taken }\end{array} & \begin{array}{l}\text { gone } \\ \text { gonen }\end{array} & & \end{array}$

2. kõ aboduri máaya dera

cordyline aboduri seeds those

fore iba'ae

broken are

$\begin{array}{llll}\text { ira } & t u^{\prime} u & s \tilde{l} & \text { dera } \\ \text { tree } & t u^{\prime} u & \text { regrowth } & \text { that }\end{array}$

debeya iba'ae

broken is

3. ba'a na'a ira waru ma'aya dera

boy your tree waru seeds those

forabo'owa'ae

broken

$\begin{array}{llllll}b a^{\prime} a & n a^{\prime} a & \text { ira } & \text { baĩ } & \text { ma'aya } & \text { dera } \\ \text { boy } & \text { your } & \text { tree } & \text { baĩ } & \text { seeds } & \text { those }\end{array}$

forebiba'ae

broken off

4. momahu'u ka fofo

Momahu'u woman Fofo

kabe kawaru

man Kawaru 
Songs of the Empty Place

\begin{tabular}{|c|c|c|c|}
\hline $\begin{array}{l}\text { oro } \\
\text { bamboo }\end{array}$ & $\begin{array}{l}\text { yerebi } \\
\text { yerebi }\end{array}$ & $\begin{array}{l}\text { dobo } \\
\text { clan }\end{array}$ & $\begin{array}{l}\text { kabe } \\
\text { man }\end{array}$ \\
\hline kabe & baya & & \\
\hline man & Baya & & \\
\hline
\end{tabular}

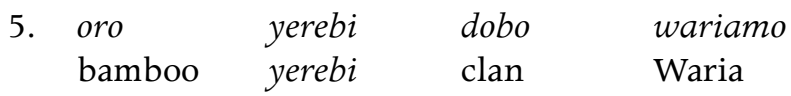

kabe baya

man Baya

yo hua ka fofomo

his mother woman Fofo

kabe kawaru

man Kawaru

1. Boy, your tegeri cordyline shoots

Have been broken off

Boy, your kegebe vine shoots

Someone has broken them off and taken them away

2. Those aboduri shoots of yours

Have been broken off

The regrowth on the $t u^{\prime} u$ tree

Someone has taken them away

3. Boy, your waru tree shoots

Have long been broken off

Boy, your baĩ tree shoots

Are broken off

4. The Momahu'u clan woman, Fofo

Her son, Kawaru

The yerebi bamboo clan man, Waria

His son, Baya

5. The yerebi bamboo clan man Waria

His son, Baya

His mother, the woman Fofo

Her son, Kawaru 


\section{Men's Song 11}

\section{Singers: Gesa and Sariaba. Recorded 7 January 1985 at Barutage village.}

This song commemorates Baruma, a man of Barutage. The rhetorical use of the command verb endings evokes indignation and sorrow at the death of Baruma. (See Weiner 1991:95-97, 105-6; 1998a:339.) J online example 10.

1. $i b u$

creek

barua

ga

iga

iga

Barua

source

path

path

ere'e

look!

kumagi iga

Kumagi path

iga ereyiya'abe

path do you not see?

2. $b a^{\prime} a \quad n a^{\prime} a \quad i b u$

boy

your

river

faya'a ga

iga

iga ere'e

path look!

ba'a na'a ibu faya'a ga iga

boy your river Faya'a source path

iga ere'e

path look!

3. kumagi tage

iga

Kumagi-mouth

path

iga kigiba'ae

path bush covered

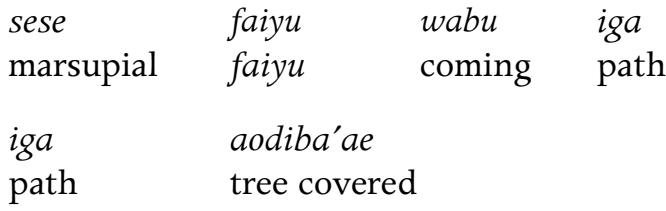




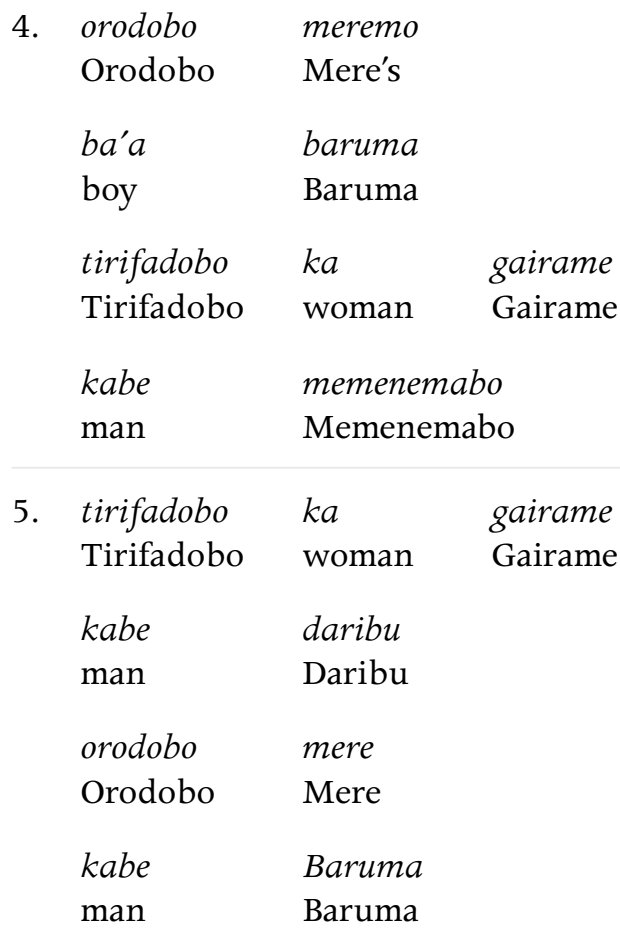

1. The path to Baruaga Creek

Look at the path!

The path to Kumagi Creek

Do you not see it?

2. Boy, the head of the Faya'a River

Look at it now!

Boy, your Faya'a River source land

Just see what it looks like now!

3. The path leading to the mouth of the Kumagi Creek

It is covered with bush

The path along which the faiyu marsupial travels

Has been covered over with bush

4. The Orodobo man, Mere

His son, Baruma

The Tirifadobo woman Gairame

Her son, Memenemabo 
5. The Tirifadobo woman Gairame Her son, Daribu

The Orodobo man Mere His son Baruma

\section{Men's Song 12}

\section{Singers: Gesa and Sariaba. Recorded 7 January 1985 at Barutage village.}

This song commemorates the man Duri of Barutage. There is often a sense of mingled resentfulness and fatalism when men sing, 'let another man steal your sago palms your garden land' in regard to the productive acts the deceased leaves behind.

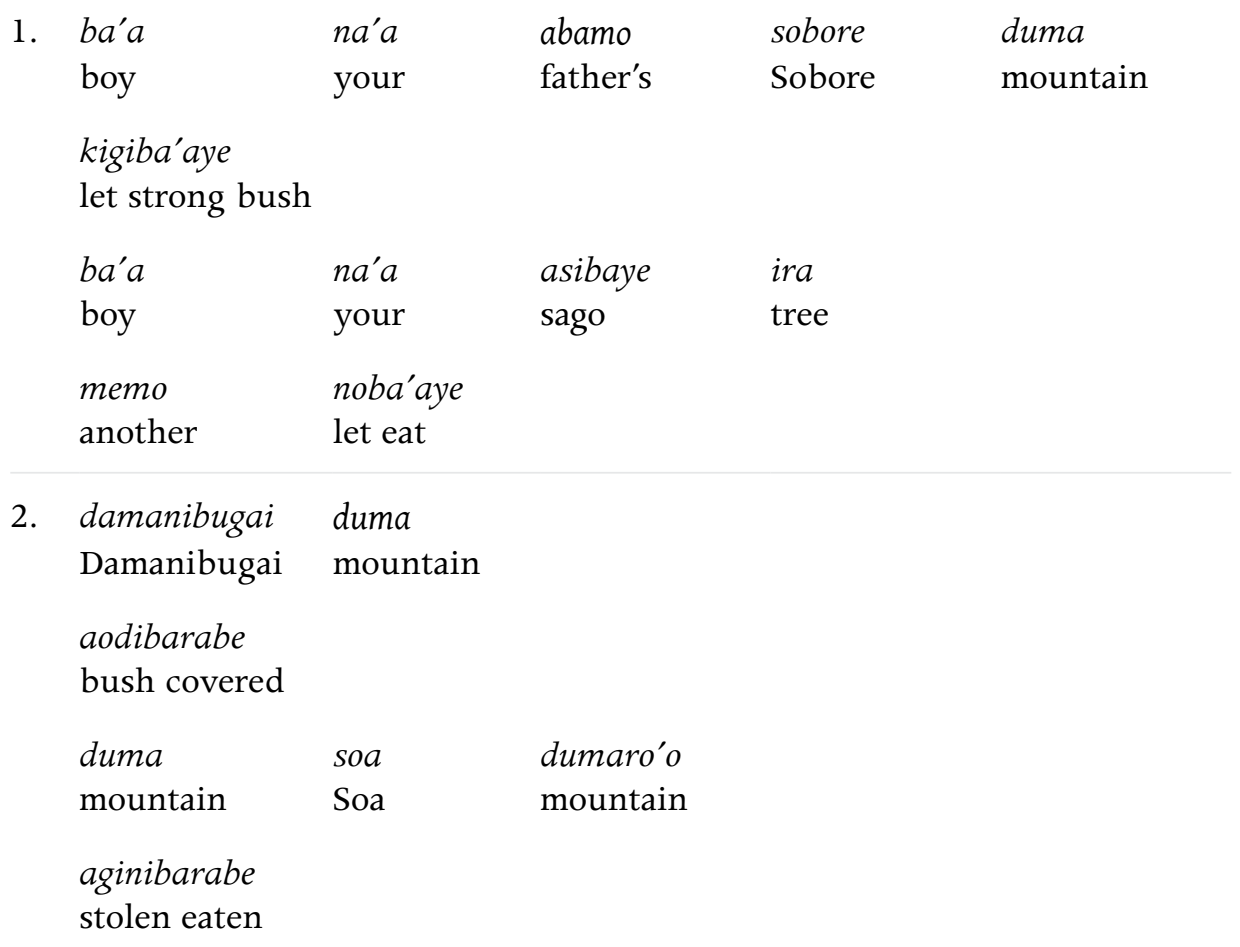




\begin{tabular}{|c|c|c|c|c|c|}
\hline \multirow[t]{8}{*}{3.} & & mogebo & \multirow{8}{*}{$\begin{array}{l}\text { dobo } \\
\text { clan }\end{array}$} & \multirow{8}{*}{$\begin{array}{l}k a \\
\text { woman }\end{array}$} & \multirow{6}{*}{$\begin{array}{l}\text { bae } \\
\text { Bae }\end{array}$} \\
\hline & Orodobo & Mogebo & & & \\
\hline & kabe & duri & & & \\
\hline & man & Duri & & & \\
\hline & ira & yĩa & & & \\
\hline & tree & yĩa & & & \\
\hline & $b a^{\prime} a$ & kubira & & & \\
\hline & boy & Kubira & & & \\
\hline \multirow[t]{8}{*}{4.} & ira & onono & dobo & $k a b o$ & wasiano \\
\hline & tree & onono & clan & woman & Wasiano \\
\hline & $b a^{\prime} a$ & duri & & & \\
\hline & boy & Duri & & & \\
\hline & oro & yerebi & dobo & kabe & bae \\
\hline & bamboo & yerebi & clan & man & $\mathrm{Bae}$ \\
\hline & ira & kubira & hoaborabo & & \\
\hline & tree & kubira & dawabo & & \\
\hline
\end{tabular}

1. Boy, your father's Mt Sobore

Let the bush cover it up

Boy, your sago palms

Another man has eaten them

2. Your Mt Damanibugai

Let the bush obliterate it

Your Mt Soa

Let another man steal it

3. The Orodobo man Mogebo

His son Duri

The clan of the yĩa tree, the man Bae

His son Kubira

4. The clan of the onobo tree, the woman Wasiano

Her son Duri

The clan of the yerebi bamboo, the man Bae His son, the kubira tree 


\section{Men's Song 13}

\section{Singers: Nabu and Bogo. Recorded 7 January 1985 at Barutage village.}

The butterflies referred to in this song are those such as the rhinoceros beetle that leave edible larvae. The dead man is likened to a fallen tree visited by egglaying insects, suggesting regeneration from death. (See Weiner 1991:97-99.) J. online example 10.

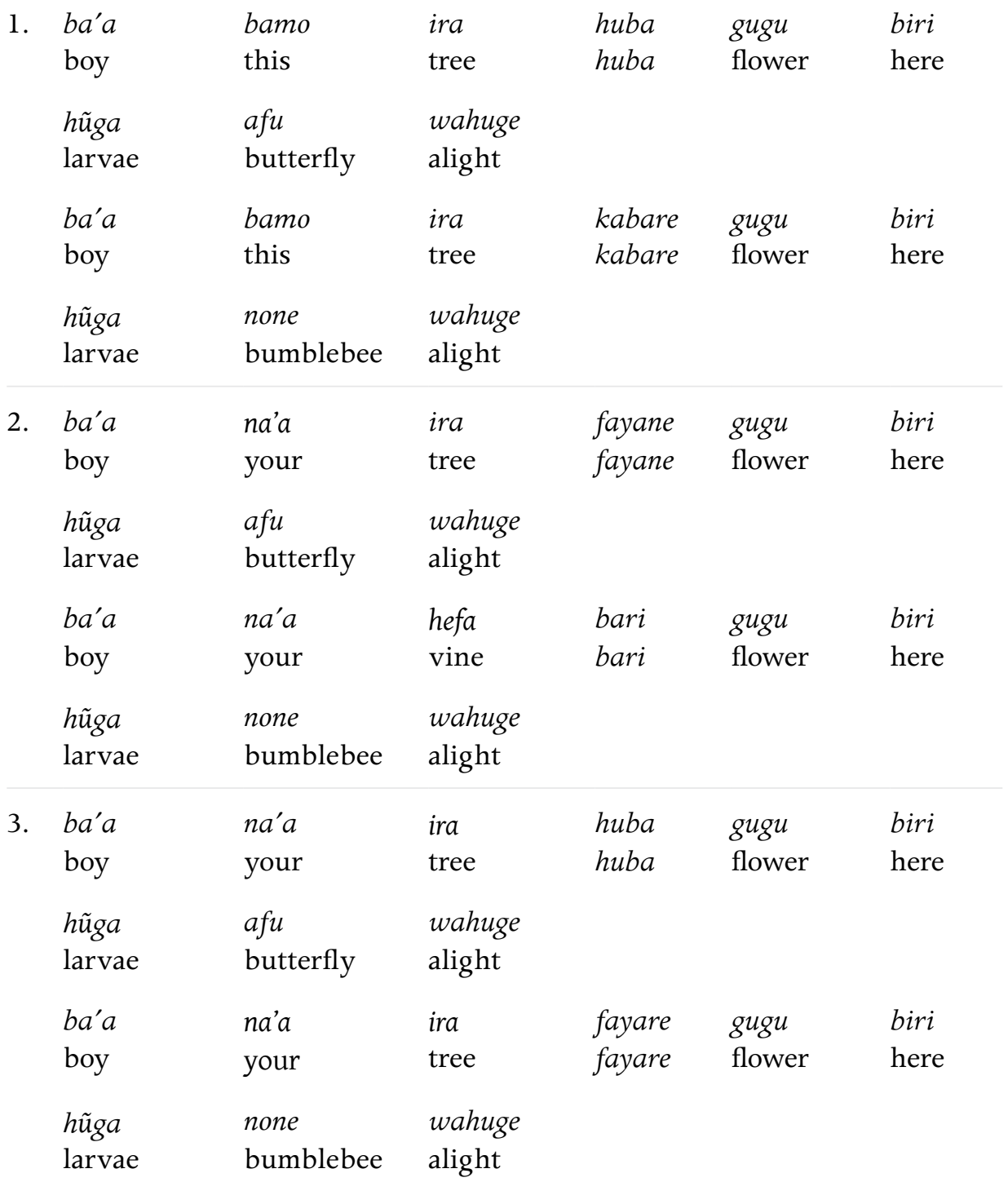




$\begin{array}{llll}\text { 4. aidobo } & b a^{\prime} a & \text { bereromo } & u^{\prime} u b i \\ \text { Aidobo } & \text { boy } & \text { Berero's } & \text { child } \\ \text { ba'a } & \text { howare } & \\ \text { boy } & \text { Howare } & \\ \text { momahu'u } & k a & \text { genemo } \\ \text { Momahu'u } & \text { woman } & \text { Genemo } \\ \text { dawa } & & \\ \text { dawabo } & & \end{array}$

$\begin{array}{lll}\text { 5. momahu'u } & \text { kabo } & \text { genemoka } \\ \text { Momahu'u } & \text { girl } & \text { Genemoka } \\ \text { ba'a } & \begin{array}{l}\text { herere } \\ \text { boy }\end{array} & \\ \text { Herere } & \\ \text { Aidobo } & \text { berero } & \\ \text { kabe } & \text { Berero } & \\ \text { man } & \text { Howare } & \end{array}$

1. On the flowers of your huba palm The afu butterfly alights

On the flowers of your kabare tree The none bumblebee alights

2. On the flowers of your fayane tree The afu butterfly alights

On the flowers of your hefa bari vine The none bumblebee alights

3. On the flowers of your huba palm The afu butterfly alights

On the flowers of your fayare tree The none bumblebee alights

4. The Aidobo clan, the man Berero His son Howare

The Momahu'u clan woman Genemo 
5. The Momahu'u clan woman Genemoka

Her son Herere

The man of the Aidobo clan, Berero

His son Howare

\section{Men's Song 14}

\section{Singers: Nabu and Bogo. Recorded 7 January 1985 at Barutage village.}

Visits by men and women of other longhouses are often encounters comprising equal parts of affability, neighbourliness, and the nervous competitiveness of hosts and visitors alike. This song, sung by two young Barutage men, mocks the Hegeso men's insults directed towards Barutage. 'Are we women that you should tell us to make gardens and cook sago,' the song is saying. Hegeso longhouse lies upstream of Barutage longhouse along the Mubi River. 'First' sago refers to what the Foi call kare kui, 'woman's sago,' the sago that a woman cooks first when she is preparing the evening meal, and which she eats first. (See Weiner 1991:165-67.)

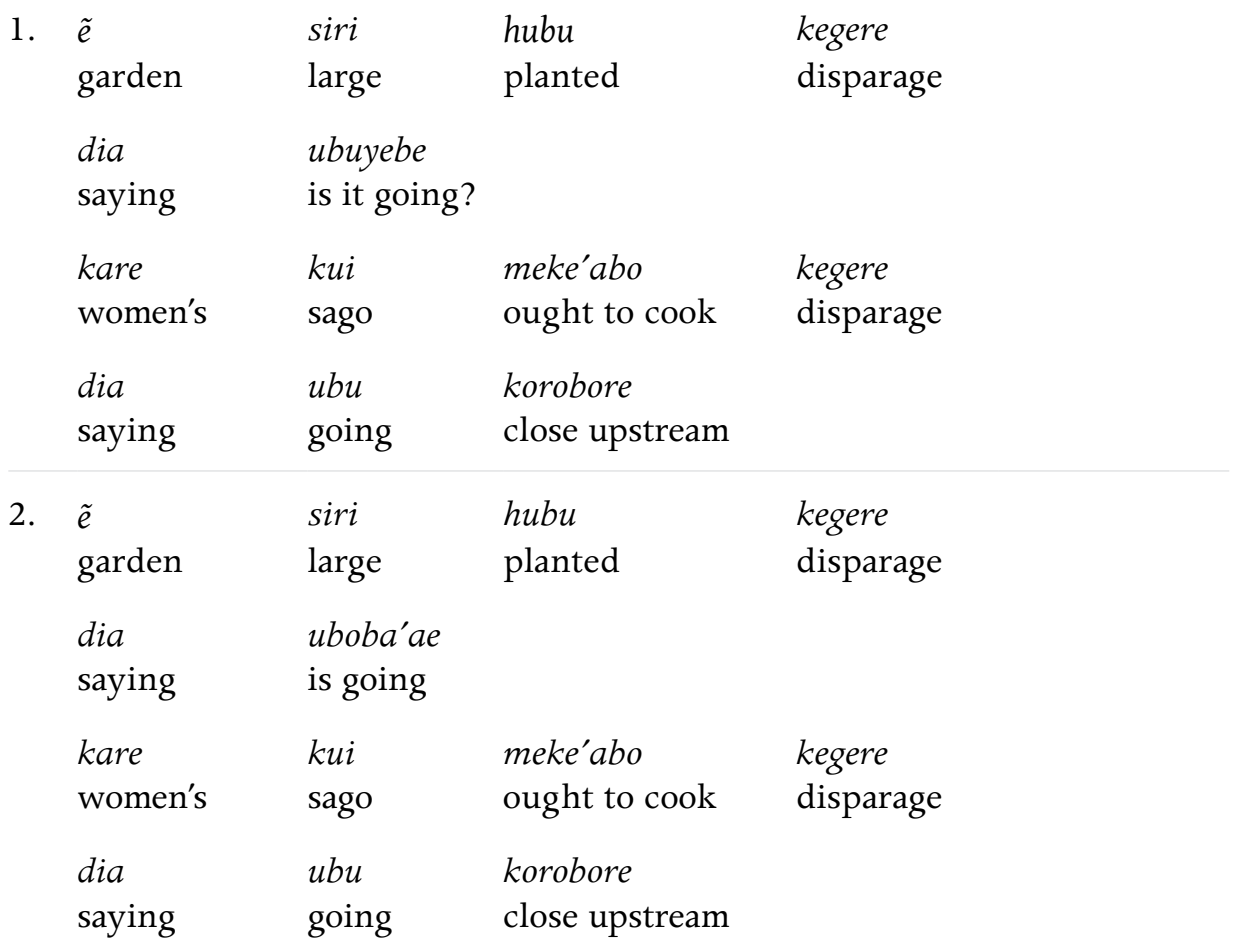




$\begin{array}{lllll}\begin{array}{l}\text { 3. } \begin{array}{l}\text { yiya } \\ \text { we }\end{array} \\ \text { men }\end{array} & \begin{array}{l}\text { ibu } \\ \text { river }\end{array} & \begin{array}{l}\text { faya'a } \\ \text { Faya'a }\end{array} & \begin{array}{l}\text { wagibu } \\ \text { mouth }\end{array} \\ \begin{array}{l}\text { dawabo } \\ \text { dawabo }\end{array} & & & \\ \text { yiya } & \text { amena } & \text { igiri } & \text { sabe } & n \text { na'abo }^{\prime} \\ \text { we } & \text { men } & \text { Igiri } & \text { Ridge } & \text { to you } \\ \text { dawabo } & & & & \\ \text { dawabo } & & & & \end{array}$

$\begin{array}{lll}\text { 4. } \begin{array}{ll}\text { amena } \\ \text { men }\end{array} & \begin{array}{l}\text { yagenebo } \\ \text { Yagenebo }\end{array} & \begin{array}{l}\text { sabe } \\ \text { Ridge }\end{array} \\ \begin{array}{l}\text { dawabo } \\ \text { dawabo }\end{array} & \\ \text { amena } & \text { igiri } & \text { sabe } \\ \text { men } & \text { Igiri } & \text { Ridge } \\ \text { ibudawabo } & & \\ \text { dawabo } & & \end{array}$

1. You should plant a big garden, you jeer at me Is this what you are saying?

You should be cooking First sago, you insult me People pass this talk as they go upstream ${ }^{4}$

2. I should plant a big garden, you derogate me This is what you are saying

I ought to cook First sago, you insult me People are talking about me as they go upstream

3. We sing of you men of the Faya'a Creek mouth Dawabo

You men of Sorofigitono

Dawabo

\footnotetext{
4 'Talk going upstream': people spreading a story as they paddle back to their bush houses upon leaving the longhouses (applies to Hegeso and Barutage only; Herebo bush houses are mostly downstream from the longhouse).
} 
4. We sing of you men of Yagenebo Ridge

Dawabo

You men of Igiri Ridge

Ibu Dawabo

\section{Men's Song 15}

\section{Singers: Nabu and Bogo. Recorded 7 January 1985 at Barutage village.}

When men beat the drums during the Usane habora night-time dancing, women are supposed to be irresistably drawn romantically to the male performers. Women, as they make sago, very commonly sing to their husbands, 'don't come around with your sweet-talking drum and try to entice me away from work.' (See Weiner 1991:167-69.)

1. ira

$$
\text { tengo }
$$

so'a

nomo

tree

tengo

drum

to me

odibihamone

do not call out

$\begin{array}{llll}\text { ira } & \text { sugu } & \text { so'a } & \text { nomo } \\ \text { tree } & \text { sugu } & \text { drum } & \text { to me }\end{array}$

odobobareo

shouldn't call out

2. ira

$$
\text { sugu }
$$

$\mathrm{Sa}^{\prime} \mathrm{O}$

nomo

tree

sugu

drum

to me

odibihamone

do not call out

$\begin{array}{llll}\text { ira } & \text { suabo } & s a^{\prime} o & \text { nomo } \\ \text { tree } & \text { suabo } & \text { drum } & \text { to me }\end{array}$

odobobarebe

shouldn't call out 


$\begin{array}{llll}\begin{array}{l}\text { 3iya } \\ \text { we }\end{array} & \begin{array}{l}\text { amena } \\ \text { men }\end{array} & \begin{array}{l}\text { sorofigi } \\ \text { Sorofigi }\end{array} & \begin{array}{l}\text { tono } \\ \text { Ridge }\end{array} \\ \begin{array}{l}\text { dawabo } \\ \text { dawabo }\end{array} & & \\ \text { yiya } & \text { amena } & \text { yabagamu } & \\ \text { we } & \text { men } & \text { Yabagamu } & \\ \text { ibudawabo } & & \\ \text { ibudawabo } & & \end{array}$

$\begin{array}{ll}\text { 4. amena } & \text { yabagamu } \\ \text { men } & \text { Yabagamu }\end{array}$

dawabo

dawabo

$\begin{array}{lll}\text { amena } & \text { kana } & \text { derege } \\ \text { men } & \text { stone } & \text { side }\end{array}$

dawabo

dawabo

1. Your tengo tree drum

Don't call out to me

Your sugu tree drum

You shouldn't call to me

2. Your sugu tree drum

Don't cry out to me

Your suabo tree drum

Don't call out my name

3. We are the men of Sorofigitono

Dawabo

We are the men of Yabagamu

Ibu Dawabo

4. We are the men of Yabagamu

Dawabo

We are the men of the mountain side

Dawabo 


\section{Men's Song 16}

\section{Singers: Oromene and Fahaisabo. Recorded 7 January 1985 at Barutage village.}

The deceased, who died from sorcery and was characteristically emaciated upon death, is described in terms of his now ill-fitting clothing, hanging loose upon his frame. The song also refers to the accusations of sorcery that invariably occur at these times. In this case, a Banimahu'u clan man was accused of complicity in the man's death. (See Weiner 1991:109-10.)

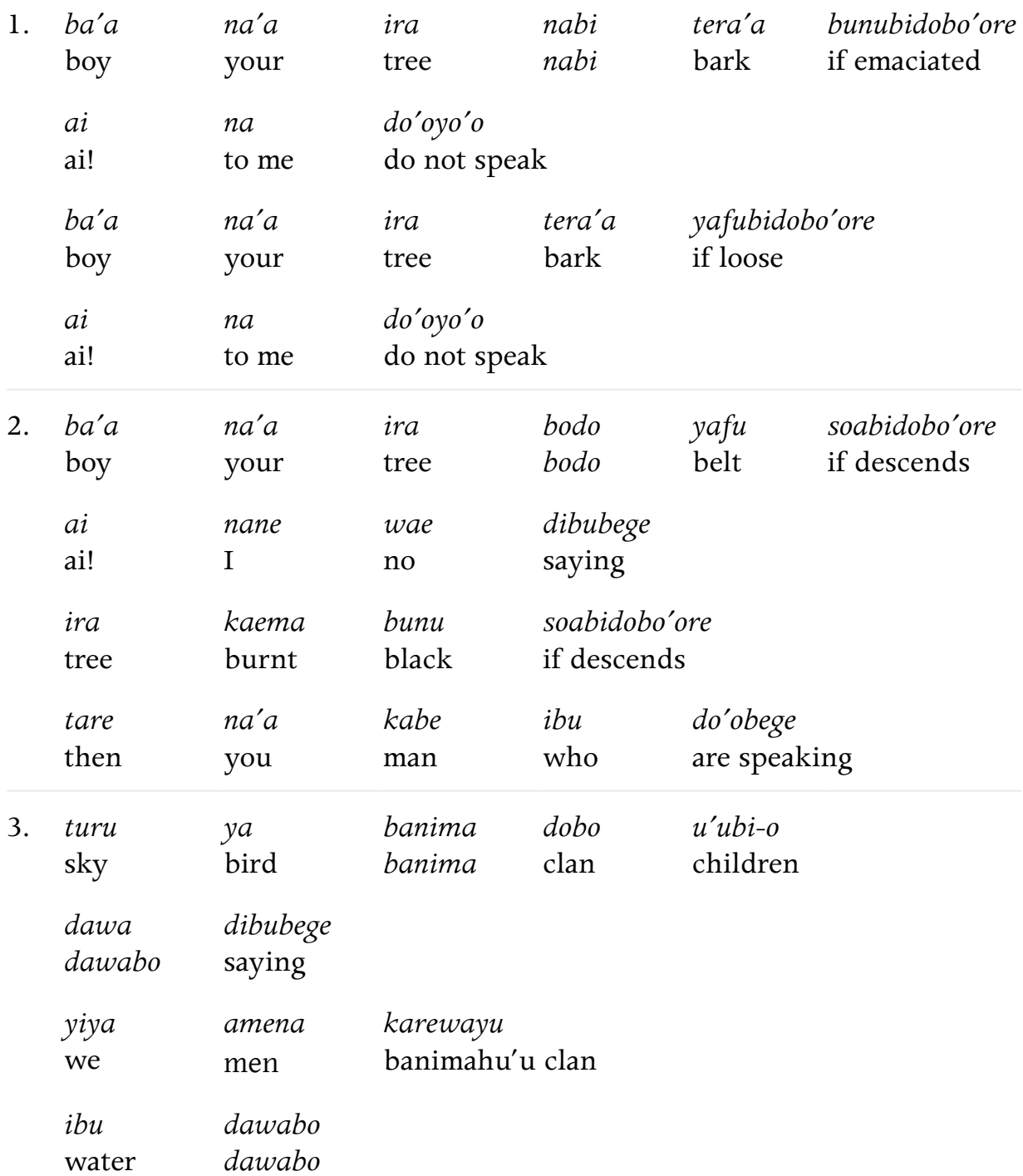




$\begin{array}{llllll}\begin{array}{l}\text { 4iya } \\ \text { we }\end{array} & \begin{array}{l}\text { amena } \\ \text { men }\end{array} & \begin{array}{l}\text { karewayu } \\ \text { banimahu'u clan }\end{array} & \\ \begin{array}{l}\text { kabe } \\ \text { man }\end{array} & \begin{array}{l}\text { dawa } \\ \text { dawabo }\end{array} & \begin{array}{l}\text { dibubege } \\ \text { saying }\end{array} & & \\ \text { yiya } & \text { amena } & \text { ya } & \text { banima } & \text { dobo } & \text { u'ubi } \\ \text { we } & \text { men } & \text { bird } & \text { banima } & \text { clan } & \text { children } \\ \text { ibu } & \text { dawabo } & & & & \\ \text { water } & \text { dawabo } & & & & \end{array}$

1. Boy, your nabi tree bark belt grown loose around your waste But do not tell me about it

Boy, your bark belt hangs loose around your thin waist But why tell me about it?

2. Boy, your bodo tree bark belt slips down your waist But it is not me

Boy, your dredlocks have become dirty and scanty But who is it you are accusing?

3. We are the men of the high flying banima bird Dawa we say

We are the men of the Kareweyu clan Ibu Dawabo

4. We are the men of the Kareweyu clan The man Dawa we are saying We are the children of the Banimadobo clan Ibu Dawabo 


\section{Men's Song 17}

\section{Singers: Oromene and Fahaisabo. Recorded 7 January 1985 at Barutage village.}

The Barutage man Ya'asa struck his wife on the hand during an argument. A woman sang of this mistreatment in a sago melody, and the men adopted it as a sorohabora. J online example 10.

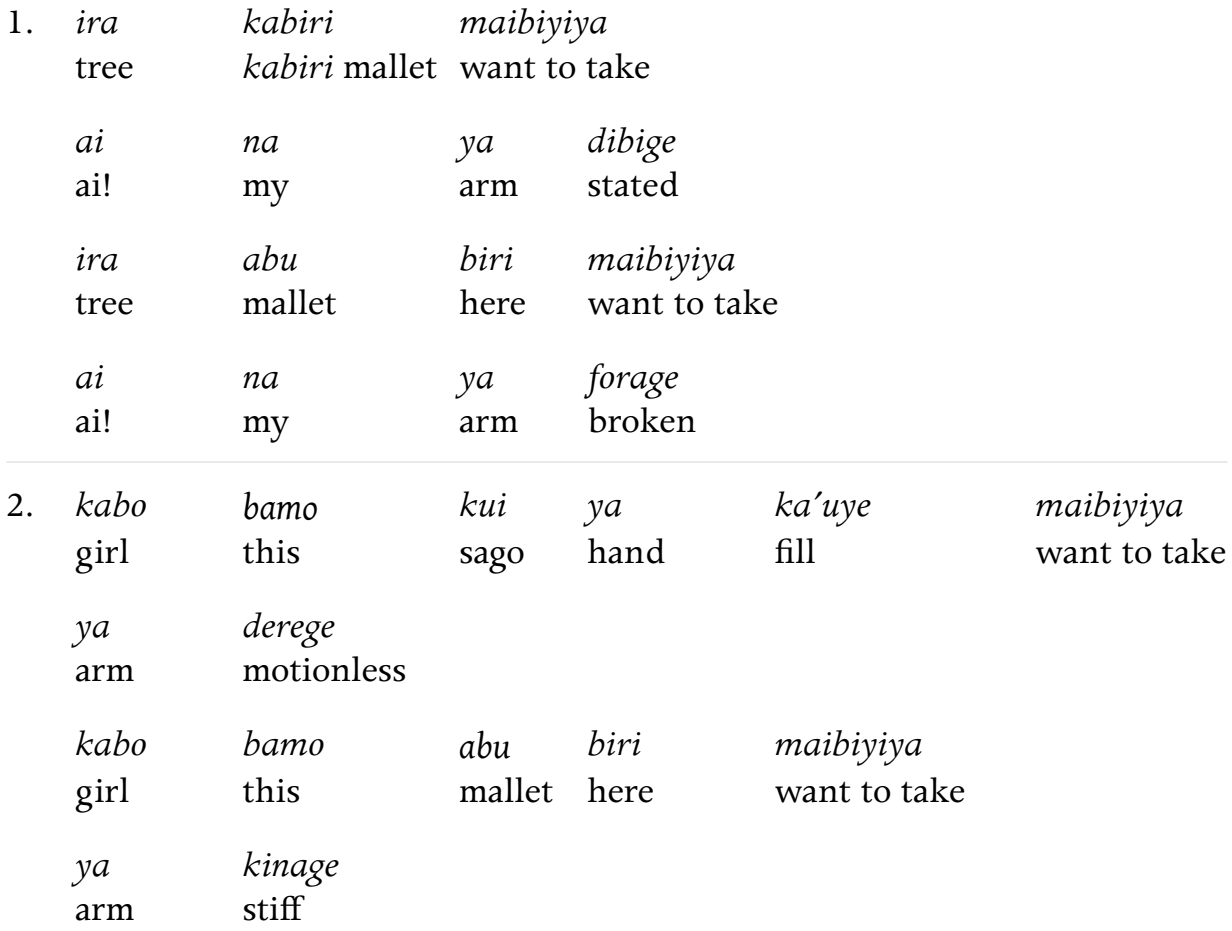

3. hua nomo ira subiwae yerihabibiyiya wasio

mother my tree paddle hold with hand well

\begin{tabular}{|c|c|c|c|c|c|}
\hline $\begin{array}{l}y a \\
\text { arm }\end{array}$ & $\begin{array}{l}\text { wayobibi'e } \\
\text { motionless }\end{array}$ & & & & \\
\hline $\begin{array}{l}\text { hua } \\
\text { mother }\end{array}$ & $\begin{array}{l}\text { nomo } \\
\text { my }\end{array}$ & $\begin{array}{l}\text { ira } \\
\text { tree }\end{array}$ & $\begin{array}{l}\text { baifarira } \\
\text { sago beater }\end{array}$ & $\begin{array}{l}\text { maibibiya } \\
\text { want to take }\end{array}$ & $\begin{array}{l}\text { dibige } \\
\text { stated }\end{array}$ \\
\hline nomo & ya & forage & & & \\
\hline my & arm & broken & & & \\
\hline
\end{tabular}




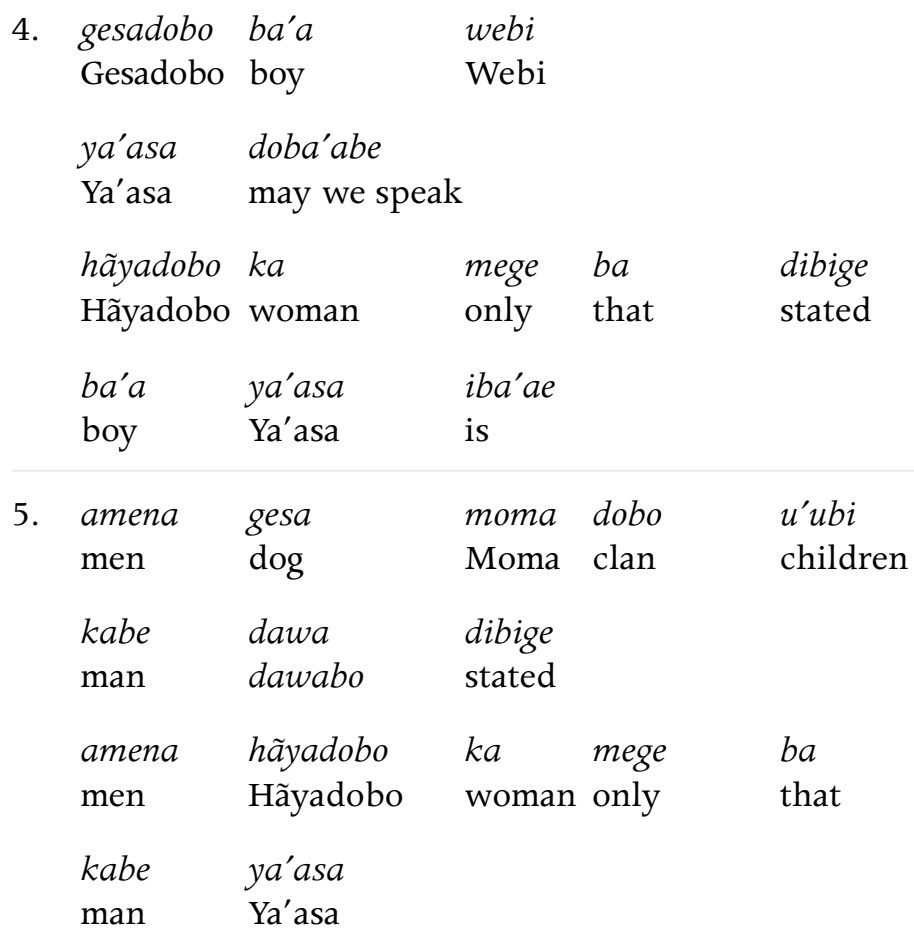

1. I want to take my kabiri wood sago mallet But my hand is broken and lifeless

I want to make sago with my abu mallet $\mathrm{Ai}$, my hand is broken and useless

2. This girl wants to fill her basket with sago But her hand is stiff and motionless

This girl wants to take her sago mallet But her hand is stiff and dead

3. Mother, I want to to hold my canoe paddle strongly But my hand is dead

Mother, I want to take my sago beating stick But my hand cannot grasp it

4. The man of the Gesadobo clan, Webi May we speak of his son, Ya'asa

The woman of the Hãyadobo clan It is her son, Ya'asa 
5. The men of the dog Moma's clan The man Dawa we are saying The woman of the Hãyadobo clan Ya'asa, her son

\section{Men's Song 18}

\section{Singers: Oromene and Fahaisabo. Recorded 7 January 1985 at Barutage village.}

This song nicely summarises the characteristics of a headman: he who helps others get married, raises many pigs, plants large gardens, and so forth. When such a man dies, his 'hand' becomes weak and lifeless. (See Weiner 1991:169-71.)

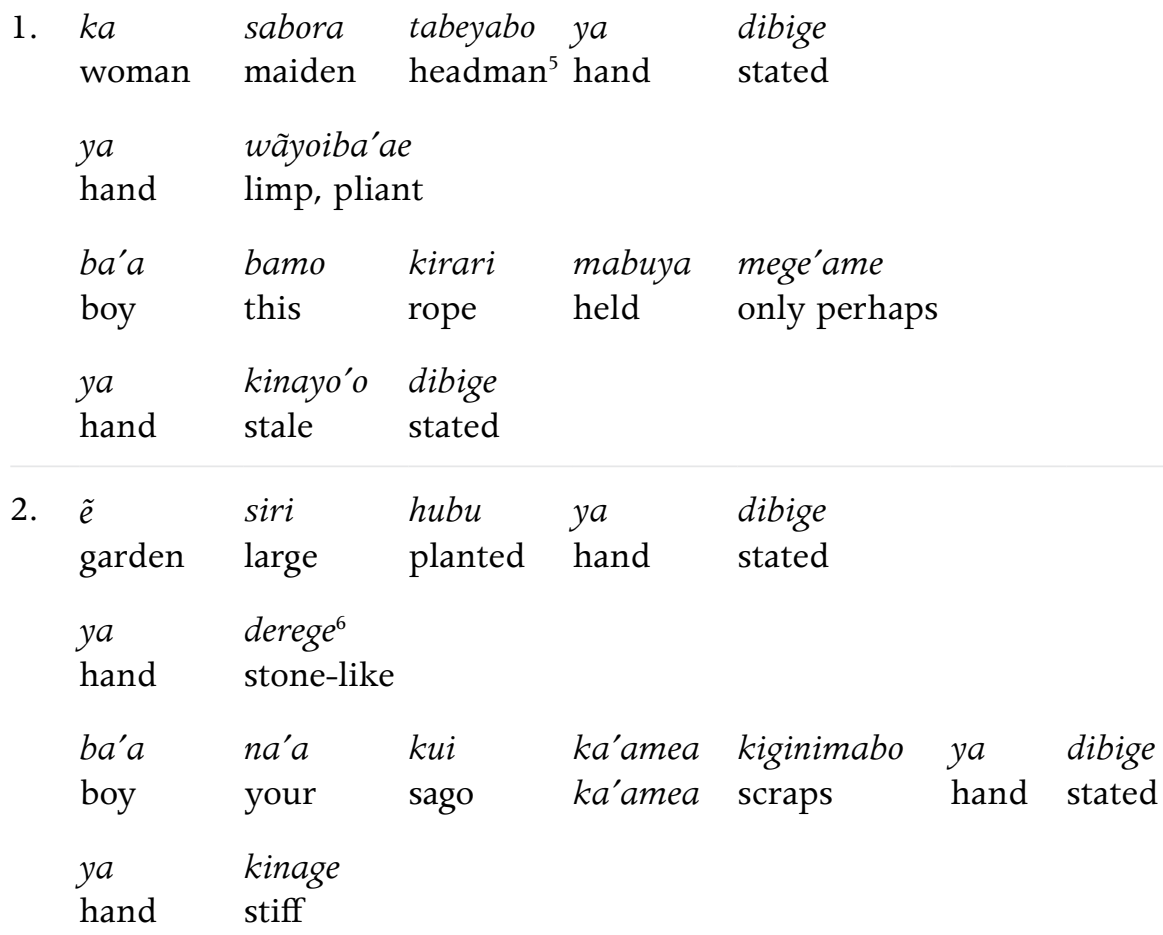

5 Kabe tabeyabo: a man who habitually raises the wealth for many men's bridewealth payments; i.e. a headman (cf. Weiner 1992:170).

6 Derege: as in kana derege, stone cliff face. 


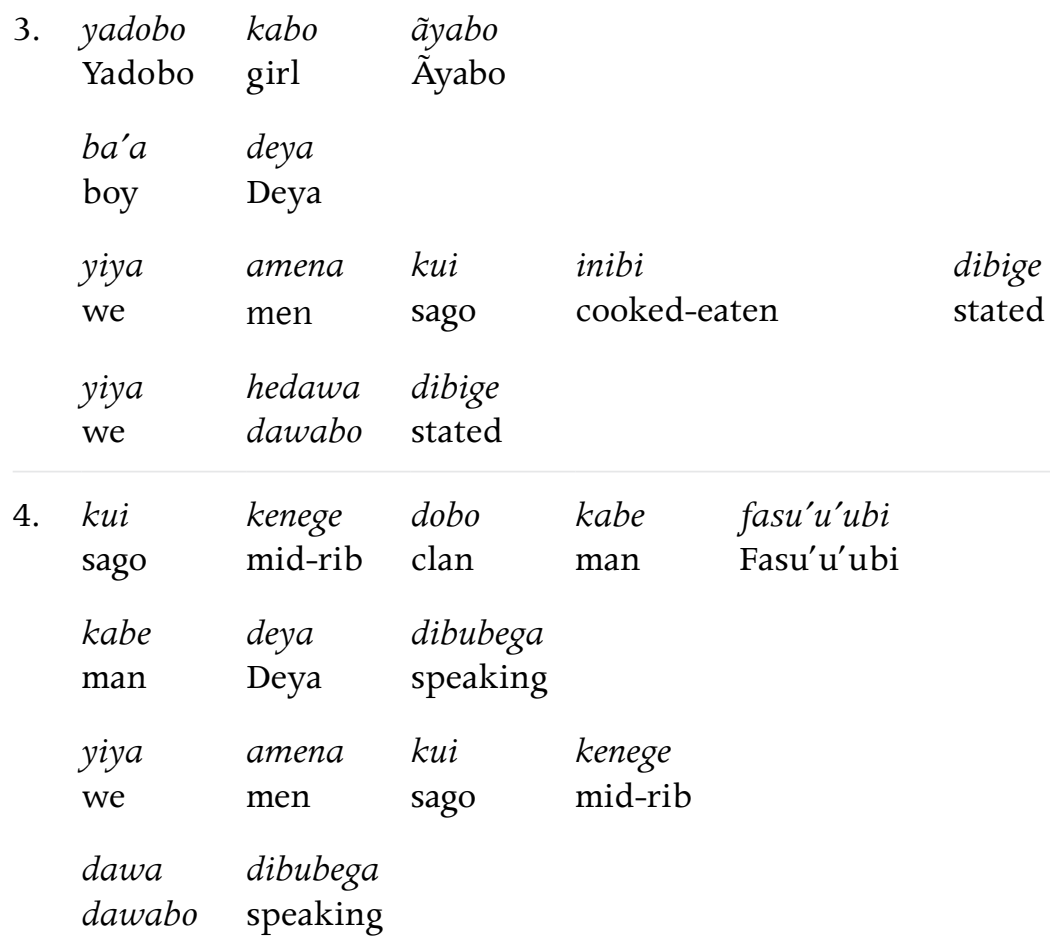

1. The man who fastens a wife for others with his own hand That hand is now weak

The man who holds the rope of the black pig

His hand is limp and weak

2. The man who cleared a great garden

His hand is stiff and lifeless

The man who gatherd $k a^{\prime}$ amea sago scraps for his many pigs

His hand is weak now

3. The Yadobo woman Ãyabo

Her son Deya

We are the men of Cooked Sago clan

Hedawa we say

4. The man of the Sago Rib clan, Fasu'u'ubi

Deya, we say

We are the men of the Sago Rib clan 


\section{Men's Song 19}

\section{Singers: Muya and Agiri. Recorded 7 January 1985 at Barutage village.}

This is a particularly beautiful song in Foi, making use of the imagery of cloudcovered mountains and limestone-littered paths so beloved by Foi singers. (See Weiner 1991:61.) J online example 10.

\begin{tabular}{|c|c|c|c|c|}
\hline 1. & $\begin{array}{l}\text { duma } \\
\text { mountain }\end{array}$ & $\begin{array}{l}a^{\prime} o \\
\text { cloud }\end{array}$ & $\begin{array}{l}\text { figibiwe'iya'are } \\
\text { part-climb-come }\end{array}$ & \\
\hline & $b a^{\prime} a$ & $n a^{\prime} a$ & igebe & \\
\hline & boy & you & is it? & \\
\hline & $\begin{array}{l}\text { duma } \\
\text { mountain }\end{array}$ & $\begin{array}{l}\text { kana } \\
\text { stone }\end{array}$ & $\begin{array}{l}\text { togebiwe'iya'are } \\
\text { overturn-come }\end{array}$ & \\
\hline & $b a^{\prime} a$ & $n a^{\prime} a$ & egebe & \\
\hline & boy & you & is it? & \\
\hline 2. & $\begin{array}{l}\text { duma } \\
\text { mountain }\end{array}$ & $\begin{array}{l}\text { kana } \\
\text { stone }\end{array}$ & $\begin{array}{l}\text { togebiwe'iya'are } \\
\text { remove-come }\end{array}$ & \\
\hline & $b a^{\prime} a$ & $n a^{\prime} a$ & igebe & \\
\hline & boy & you & is it? & \\
\hline & duma & haru & hubiwe'iya'are & \\
\hline & mountain & hill & breaking-come & \\
\hline & $b a^{\prime} a$ & na'agebe & & \\
\hline & boy & is it you? & & \\
\hline 3. & $\begin{array}{l}\text { duma } \\
\text { mountain }\end{array}$ & $\begin{array}{l}\text { busu } \\
\text { dappled light }\end{array}$ & $\begin{array}{l}\text { humekiribi } \\
\text { break through }\end{array}$ & $\begin{array}{l}\text { waba'are } \\
\text { come }\end{array}$ \\
\hline & $b a^{\prime} a$ & $n a^{\prime} a$ & igebe & \\
\hline & boy & you & is it? & \\
\hline & $\begin{array}{l}\text { duma } \\
\text { mountain }\end{array}$ & $\begin{array}{l}\text { kana } \\
\text { stone }\end{array}$ & $\begin{array}{l}\text { togebi } \\
\text { overturn }\end{array}$ & $\begin{array}{l}\text { waba'are } \\
\text { come }\end{array}$ \\
\hline & $b a^{\prime} a$ & na'agebe & & \\
\hline & boy & is it you? & & \\
\hline
\end{tabular}




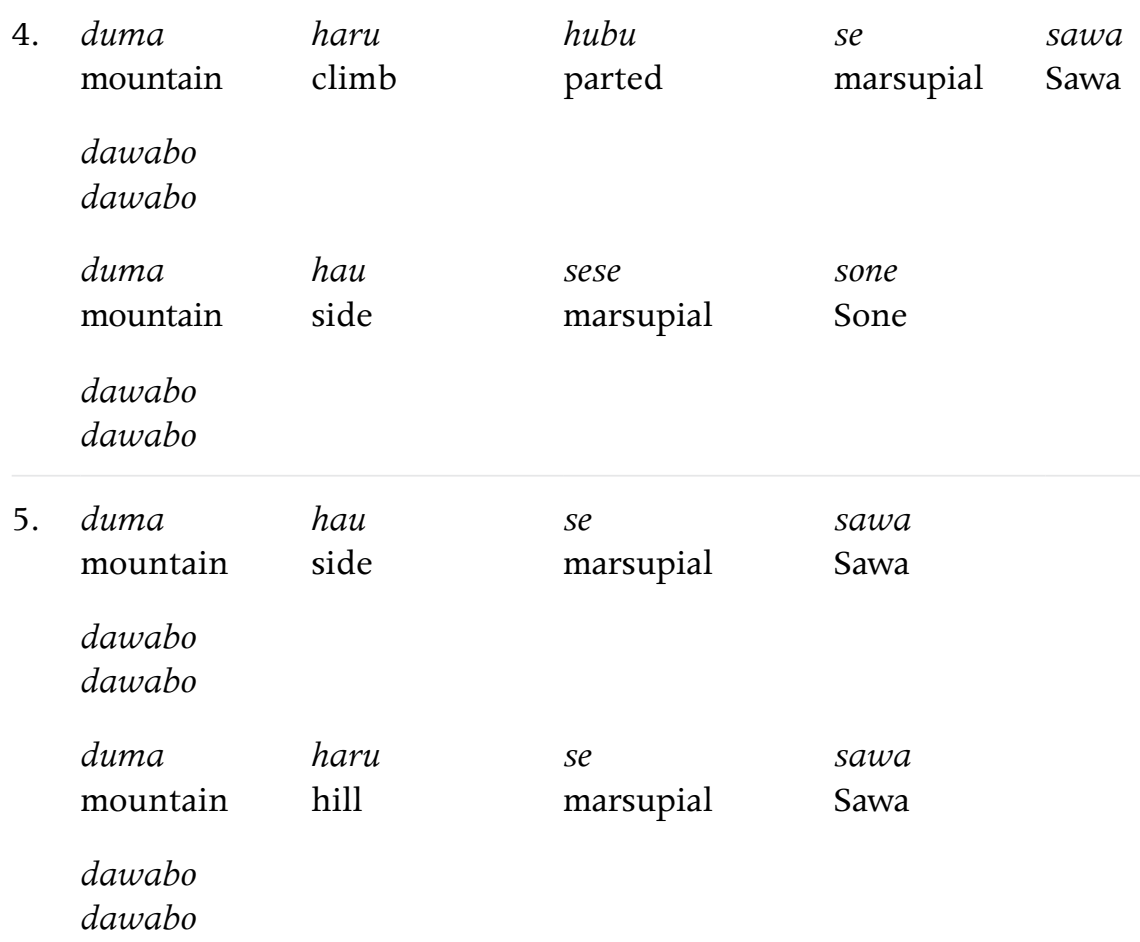

1. The mist covering the mountain parts as you come Little one is that you?

The mountain stones move aside as you come Boy, is that you?

2. You move the mountain stones as you come Boy, is that you?

You part the forest as you come down the mountain Little one, is it you?

3. You break through the dappled sunlight on the hillside Boy, is it you?

You part the stones as you come down the mountain Is that you little one?

4. The mountain climber, stone mover, Sawa the marsupial Dawabo

The mountainside dweller, Sone the marsupial 
5. Mountain side, marsupial Sawa

Dawabo

Mountain climber, marsupial Sawa

Dawabo

\section{Men's Song 20}

\section{Singers: Oromene and Fahaisabo. Recorded 5 January 1985 at Barutage village.}

This song makes use of the most popular landscape imagery for the Foi: the sounds made by swiftly flowing water. The contrast between the exuberance and ceaselessness of water and the finality and stillness of death is most poignantly expressed here. (See Weiner 1991:46, 104-5; 2001:26.) JJ online example 11.7

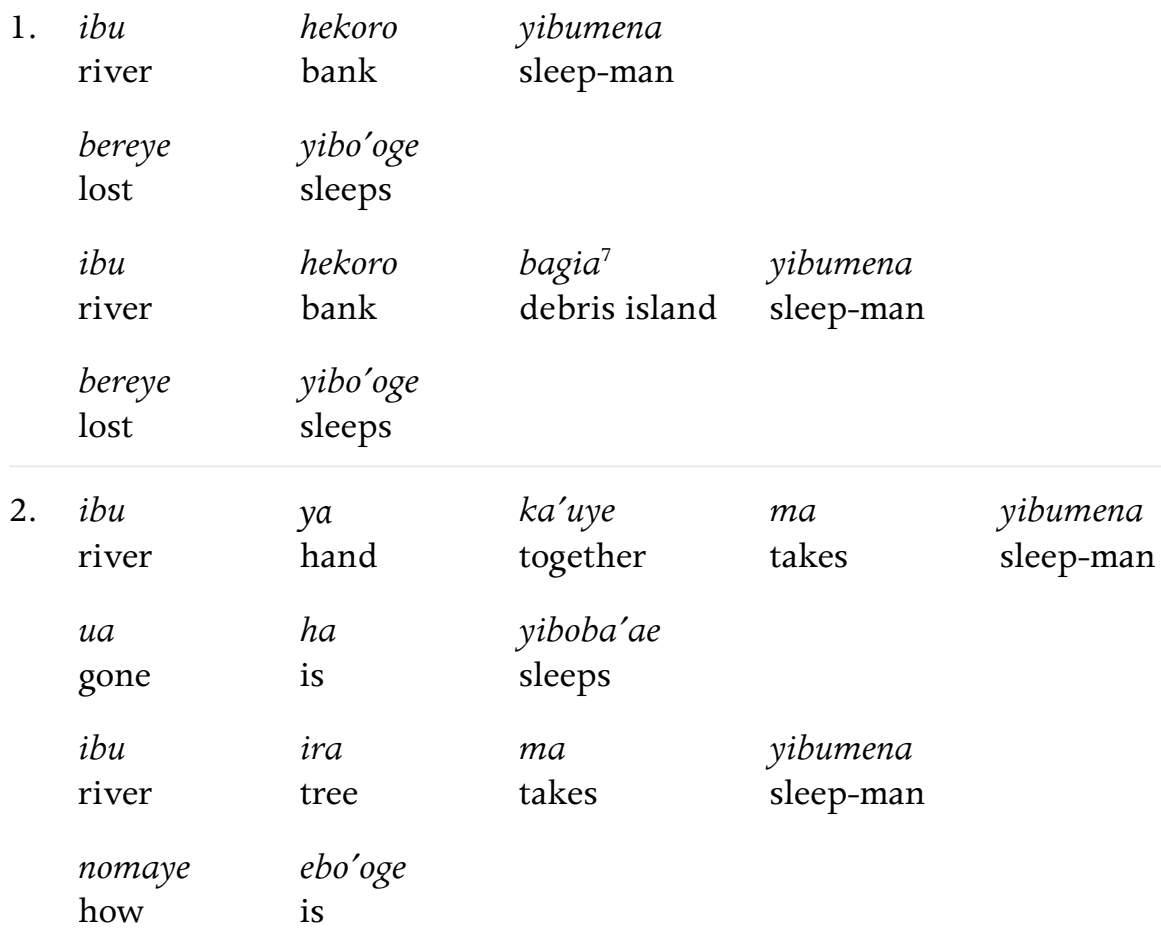

7 Bagia-: to divide into parts; hence, anything that branches out, like tree roots. And in this case, a clot of debris in the middle of a river causing the water to divide into two or more streams. 


\begin{tabular}{|c|c|c|c|}
\hline $\begin{array}{l}i b u \\
\text { river }\end{array}$ & $\begin{array}{l}\text { dimani } \\
\text { rushing }\end{array}$ & $\begin{array}{l}\text { hua } \\
\text { strikes }\end{array}$ & $\begin{array}{l}\text { yibumena } \\
\text { sleep-man }\end{array}$ \\
\hline $\begin{array}{l}\text { kabe } \\
\text { man }\end{array}$ & $\begin{array}{l}\text { nabo'oge } \\
\text { what (ha }\end{array}$ & opened) & \\
\hline $\begin{array}{l}i b u \\
\text { river }\end{array}$ & $\begin{array}{l}\text { hefofore } \\
\text { bank }\end{array}$ & $\begin{array}{l}\text { hua } \\
\text { strikes }\end{array}$ & $\begin{array}{l}\text { yibumena } \\
\text { sleep-man }\end{array}$ \\
\hline $\begin{array}{l}\text { kabe } \\
\text { man }\end{array}$ & $\begin{array}{l}\text { bereye } \\
\text { lost }\end{array}$ & $\begin{array}{l}\text { yiboba'ae } \\
\text { sleeps }\end{array}$ & \\
\hline
\end{tabular}

$\begin{array}{llll}\text { 4. kabo } & \text { heko'onomo yo } & \text { aba-o } \\ \text { girl } & \text { Heko'ono } & \text { her } & \text { father, oh! }\end{array}$

ibudawabo

ibudawabo

$\begin{array}{llll}b a^{\prime} a & \text { bugimena } & \text { yo } & a b a-o \\ \text { boy } & \text { Bugimena } & \text { his } & \text { father, oh! }\end{array}$

ibuhedawabo

dawabo

5. $b a^{\prime} a$ bugimena yo aba-o

boy

Bugimena his

father, oh!

ibudawabo

ibudawabo

$k a b o$

girl

heko'onomo yo

$a b a-o$

ibudawabo

ibudawabo

1. The man who sleeps by the bank of the rushing water He is lost now

Twigs and branches clot in the swift flowing water But he who sleeps there is lost

2. The man who catches fish from the water with his hand He has gone somewhere else to sleep

The man who takes the fish from the water with his hands 
What has happened to him?

3. The beautiful hissing sound of rapid water

But you who slept there, what of you?

The bank of the rushing water

The man who slept there is lost

4. The father of the girl Heko' ono

Ibu Dawabo

The father of the boy Bugimena

Ibu hedawabo

5. The father of Bugimena

Ibu Dawabo

The father of Heko' ono

Ibu Dawabo

\section{Men's Song 21}

\section{Singers: Muya and Agiri. Recorded 5 January 1985 at Barutage village.}

This song likens the deceased to a marsupial in the forest, and recites the names of the places the marsupial travelled and slept in the hunting forest. J online example 11 .

$\begin{array}{lll}\begin{array}{l}\text { 1. duma } \\ \text { mountain }\end{array} & \begin{array}{l}\text { masiba } \\ \text { Masiba }\end{array} & \begin{array}{l}\text { dumaro'o } \\ \text { mountain }\end{array} \\ \begin{array}{l}\text { aodibihaboro } \\ \text { bush covered }\end{array} & \\ \begin{array}{l}\text { duma } \\ \text { mountain } \quad \text { bo }\end{array} & \begin{array}{l}\text { dumaro'o } \\ \text { mountain }\end{array} \\ \text { aodoboro } & & \\ \text { jungle covered } & \end{array}$




\begin{tabular}{|c|c|c|c|c|c|}
\hline 2. & $b a^{\prime} a$ & $n a^{\prime} a$ & metega & yibu & kanega \\
\hline & boy & your & hidden & sleep & cave \\
\hline & $\begin{array}{l}\text { aodoboro } \\
\text { jungle coverec }\end{array}$ & & & & \\
\hline & $b a^{\prime} a$ & $n a^{\prime} a$ & kubarihimu & iga & \\
\hline & boy & your & Kubarihimu $^{8}$ & path & \\
\hline & aodoboro & & & & \\
\hline & jungle coverec & & & & \\
\hline 3. & $i b u$ & damekebo & fera & igaro'o & \\
\hline & river & Damekebo $^{9}$ & space & path & \\
\hline & aodia & yibi & haboba'a & & \\
\hline & bush covered & sleep & remains & & \\
\hline & duma & masiba & duma & & \\
\hline & mountain & Masiba & mountain & & \\
\hline & aodia & $y i b i$ & haboba'a & & \\
\hline & bush covered & sleep & remains & & \\
\hline 4. & egadobo & humane & & & \\
\hline & Egadobo & Humane & & & \\
\hline & $b a^{\prime} a$ & hagiabe & & & \\
\hline & boy & Hagiabe & & & \\
\hline & ira & onobo & dobo & $k a$ & horaro(e) \\
\hline & tree & onobo & clan & woman & Horaro(e) \\
\hline & $b a^{\prime} a$ & sera & & & \\
\hline & boy & Sera & & & \\
\hline
\end{tabular}

8 Kubarihimu $=$ 'kubaru tree cut', i.e. named after a spot where a kubaru tree was cut down.

9 Damekebo = 'salt cooked', i.e. named after a place where vegetable salt was prepared. 
5. ira

tree

onobo

dobo

kabo

horare

$b a^{\prime} a$

onobo

clan

girl

Horare

boy

hagiabe

egadobo

Hagiabe

Egadobo

humane

$b a^{\prime} a$

Humane

boy

sera

Sera

1. The mountain Masiba

Is covered with bush

The forest covered mountain

Reclaimed by the bush

2. Boy, your hidden cave in which you slept

Is covered over by the jungle

Boy, your path to Kubarihimu Creek

Has been taken back by the bush

3. The Damekebo path which cuts its way through the mountain

Is covered over by the jungle

The mountain Masiba

Has been covered over by the bush

4. Humane of the Egadobo clan

His son, Hagiabe

The woman of the onobo tree clan, Horare

Her son, Sera

5. The onobo clan woman Horare

Her son Hagiabe

The man of the Egadobo clan, Humane

His son, Sera 


\section{Men's Song 22}

\section{Singers: Muya and Agiri. Recorded 5 January 1985 at Barutage village.}

The dogs named Awaro and Kimi appear in the myth 'Moon-man and Sun-girl', concerning the origin of the sun and moon, originally collected by F. E. Williams (1940-42:149-51; 1977:317-20). They seem to be unspecific names for dogs, much as 'Fido' is for Americans. (See Weiner 1991:47; 2001:26.) J online example 12 .

\begin{tabular}{|c|c|}
\hline $\begin{array}{l}\text { awaro } \\
\text { Awaro }\end{array}$ & $\begin{array}{l}\text { yiadira'ame } \\
\text { cries out perhaps }\end{array}$ \\
\hline $\begin{array}{l}\text { naye } \\
\text { how }\end{array}$ & $\begin{array}{l}\text { uge } \\
\text { gone }\end{array}$ \\
\hline $\begin{array}{l}\text { kimi } \\
\text { Kimi }\end{array}$ & $\begin{array}{l}\text { yiadira'ame } \\
\text { cries out perhaps }\end{array}$ \\
\hline $\begin{array}{l}\text { naye } \\
\text { how }\end{array}$ & $\begin{array}{l}\text { uge } \\
\text { gone }\end{array}$ \\
\hline
\end{tabular}

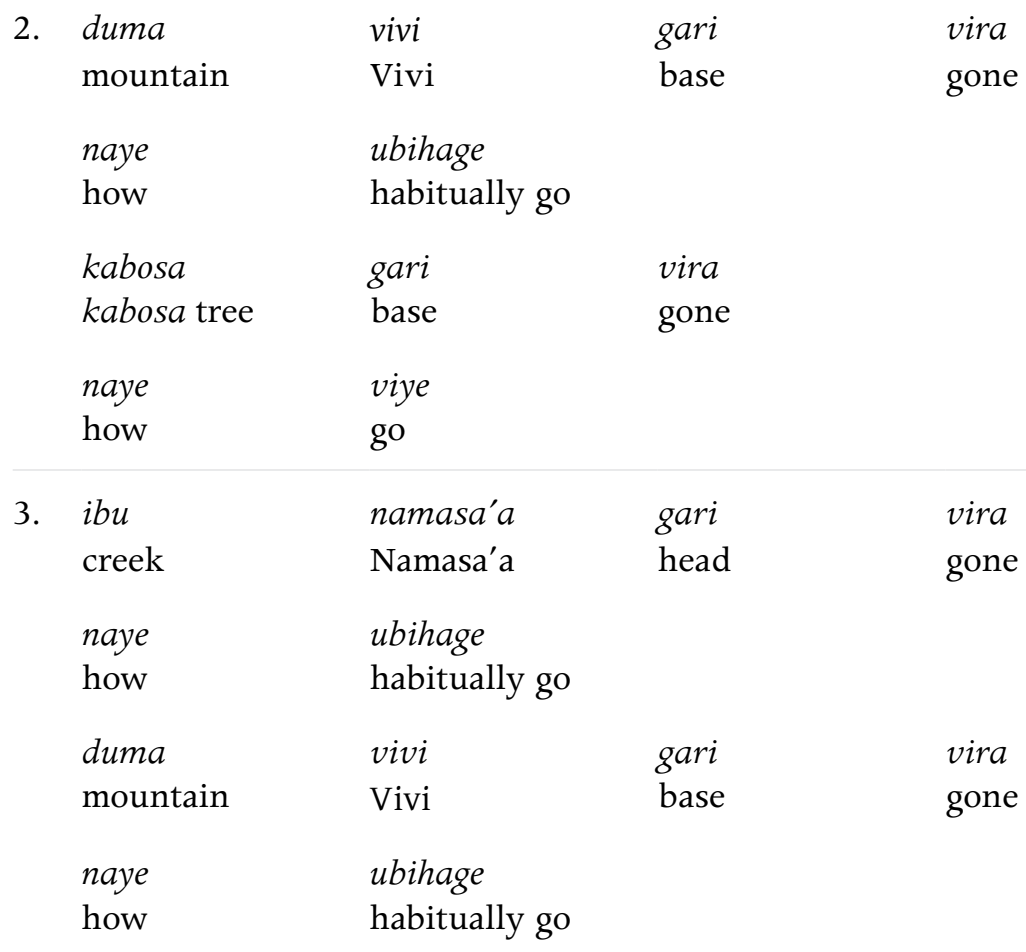


4. abaru

Abaru

naye

how

kimi

Kimi

naye

how

5. ira

tree

dawabo

dawabo

ira

tree

dawabo

dawabo

6. orodobo

Orodobo

kibudobo

Kibudobo

kibudobo

Kibudobo

kabe

man

vibu

Vibu

$b a^{\prime} a$

boy

ira

tree

$b a^{\prime} a$

boy ka

woman

gamabo

Gamabo

kibudobo

Kibudobo

gamabo

Gamabo kabe

vibu

man

Vibu bononobo

Bononobo

1. The dog Awaro cries out

How will it find the way now?

The dog Kimi cries out

How will it go?

2. To the base of Mt Vivi

How can he keep going?

To the base of the kabosa tree

How can it find the way? 
3. To the source of the Namasa'a Creek

How will he go?

To the base of the mountain Vivi

How will he keep going there?

4. The sound of Abaru's barking

'How will I go?' it is saying

The sound of Kimi's barking

'How will I go?' it is saying

5. The Kibudobo man, Vibu

Dawabo

The Kibudobo man, Vibu

Dawabo

6. The Orodobo woman Bononobo

Her son, Gamabo

The clan of kibu tree, the man Vibu

His son, Gamabo

\section{Men's Song 23}

\section{Singers: Habeyu and Hira. Recorded 7 January 1985 at Barutage village.}

This is a woman's sago song that was performed without any changes as a men's sorohabora. A woman is pounding sago and she hears the sound of the obo and sisi birds singing from a tree nearby. She pretends it is her sweetheart, and she answers back, 'Don't bother me now, I am making sago!'

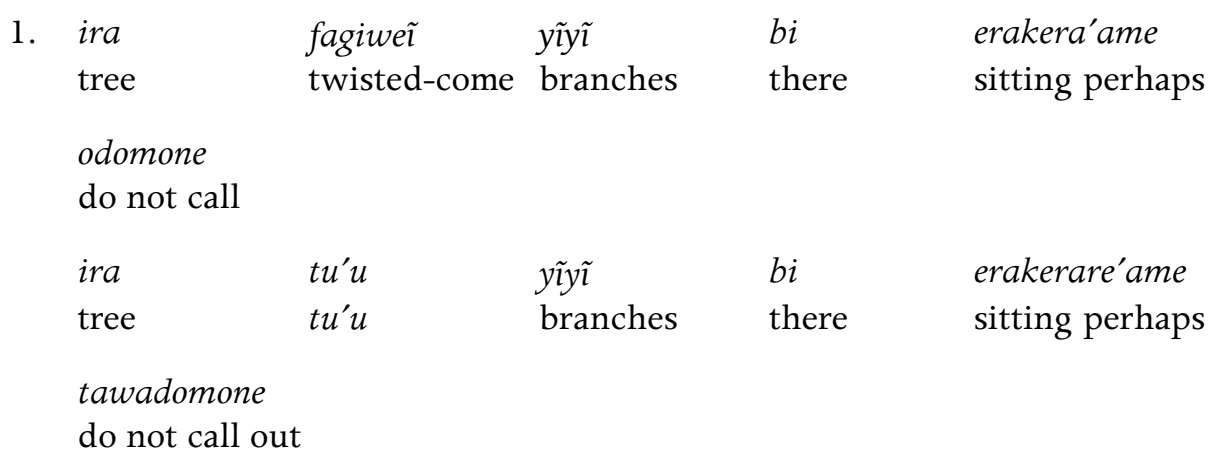




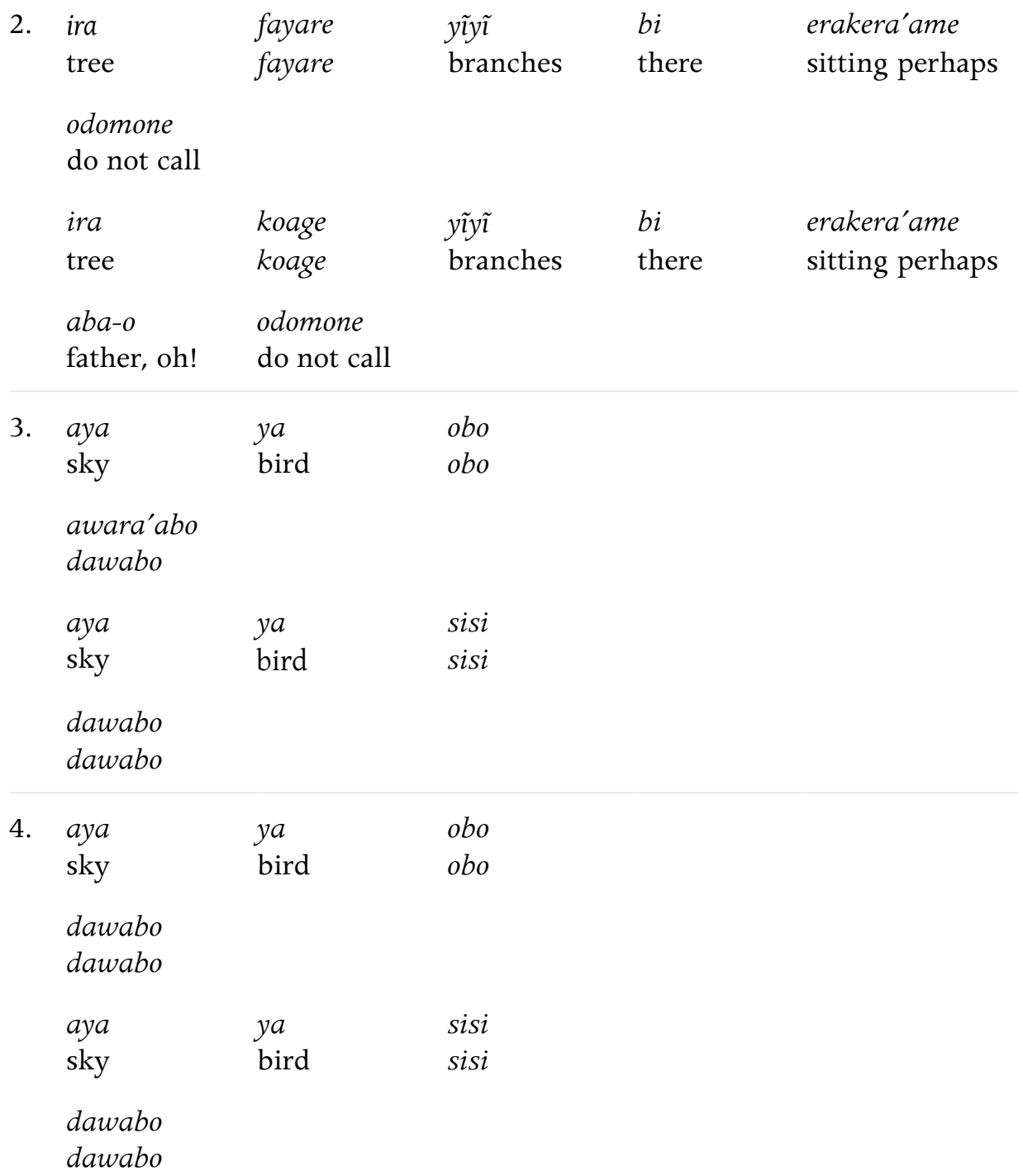


Are you sitting on the koage tree branches perhaps?

'Sister!' don't call to me

3. The obo bird above

Awara'abo

The sisi bird above

Dawabo

4. The obo bird in the sky

Dawabo

The sisi bird above

Dawabo

\section{Men's Song 24}

\section{Singers: Mare and Maniname. Recorded 7 January 1985 at Barutage village.}

This song begins as a repeated woman's sago melody with a familiar theme; it ends with the men's dawabo.

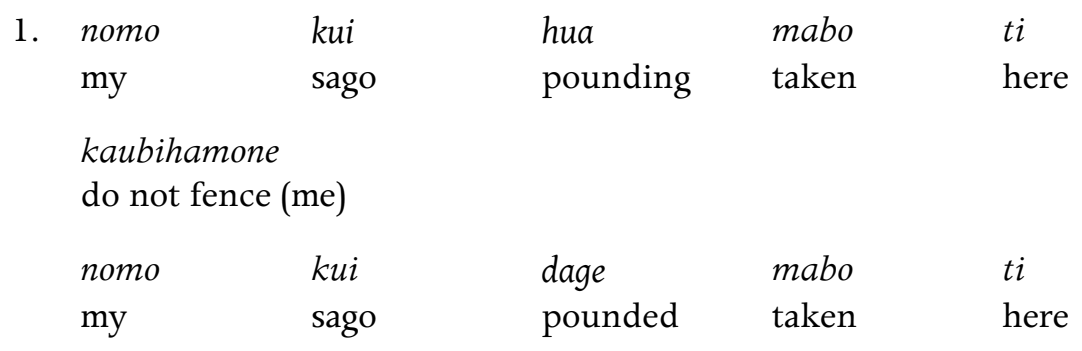

kaumone

do not encircle

2. ira

$\begin{array}{lll}\text { gibi } & \text { sa'o } & \text { nomo } \\ \text { gibi } & \text { drum } & \text { to me }\end{array}$

odibihamone

do not call out

$\begin{array}{llll}\text { ira } & \text { tiraru } & s a^{\prime} o & \text { nomo } \\ \text { tree } & \text { tiraru } & \text { drum } & \text { to me }\end{array}$


odomone

do not call

3. yiya

$\begin{array}{lll}\text { amena } & \text { nanumi } & \text { hubu } \\ \text { men } & \text { Nanumi } & \text { strongly }\end{array}$

dawabo

dawabo

yiya

amena

nanumi

hubu

$k u^{\prime} u b a \tilde{\imath}$

we

men

Nanumi

strongly

beautiful

dawabo

dawabo

4. yiya

amena

sorofigi

tono

we

men

Sorofigi

Hill

dawabo

dawabo

yiya

amena

sorofigi

tono

we

men

Sorofigi

Hill

dawabo

dawabo

1. I am working here at my sago trough

Don't crowd me here

I have my sago to pound now

Don't bother me

2. With your gibi tree-made drum

Don't sing out to me

With your tiruru tree-made drum

Don't call out my name

3. We are the men of the swiftly flowing Nanumi River

Dawabo

We are the men of the fiercely flowing Baru River

Dawabo 
4. We are the men of Sorofigitono

Dawabo

We are the men of Sorofigitono

Dawabo

\section{Men's Song 25}

\section{Singers: Gofe and Hobe. Recorded 7 January 1985 at Barutage village.}

A dead man leaves behind children, as this song commemorates. The children are referred to by reference to their toys and clothing. But the deceased is also referred to as a boy who himself has left these toys behind.

1. $b a^{\prime a} \quad n a^{\prime} a$ ira sõga bi'a mano mogoreye

boy your tree stem arrow small left

$\begin{array}{lll}\begin{array}{l}\text { ua } \\ \text { gone }\end{array} & \text { hai } & \begin{array}{l}\text { yiboro } \\ \text { sleeps }\end{array} \\ \text { ira } & \text { mamage } & \text { mefese'ame } \\ \text { tree } & \text { toy bow } & \text { left perhaps } \\ \text { bereboba'ae } & \\ \text { is lost }\end{array}$

2. ba'a na'a ira kotono gaĩya mano sina'ame

boy your tree kotono skirt small abandoned perhaps

ua ha yiboba'ae

gone is sleeps

ba'a na'a ira tera'a yefu sina'ame

boy your tree bark belt abandoned perhaps

$\begin{array}{lll}\text { ua } & \text { ha } & \text { visomoro } \\ \text { gone is } & \text { went }\end{array}$

3. ira so'one dobo kabo fana'ayome

tree so'one clan girl Fana'ayome

$b a^{\prime} a$ derabore

boy Derabore 
yo hua ka moruame

his mother woman Moruame

ibudawabo

ibudawabo

\begin{tabular}{|c|c|c|c|c|c|}
\hline $\begin{array}{l}\text { yiya } \\
\text { we }\end{array}$ & $\begin{array}{l}\text { amena } \\
\text { men }\end{array}$ & $\begin{array}{l}\text { kibudob } \\
\text { Kibudol }\end{array}$ & & $\begin{array}{l}b a^{\prime} a \\
\text { boy }\end{array}$ & $\begin{array}{l}\text { hogebomo } \\
\text { Hogebo }\end{array}$ \\
\hline $\begin{array}{l}\text { yo } \\
\text { his }\end{array}$ & $\begin{array}{l}\text { hua } \\
\text { mother }\end{array}$ & $\begin{array}{l}k a \\
\text { woman }\end{array}$ & $\begin{array}{l}\text { moruame } \\
\text { Moruame }\end{array}$ & & \\
\hline $\begin{array}{l}\text { yo } \\
\text { his }\end{array}$ & $\begin{array}{l}a b a \\
\text { son }\end{array}$ & $\begin{array}{l}b a^{\prime} a \\
\text { boy }\end{array}$ & $\begin{array}{l}\text { yafo } \\
\text { name }\end{array}$ & $\begin{array}{l}\text { dawabo } \\
\text { dawabo }\end{array}$ & \\
\hline $\begin{array}{l}b a^{\prime} a \\
\text { boy }\end{array}$ & $\begin{array}{l}\text { derabore } \\
\text { Derabore }\end{array}$ & & & & \\
\hline
\end{tabular}

1. Boy, you have left behind your toy bow and arrow It is lost

You have left behind your mamage wood toy bow and arrow Now it is lost

2. Boy, you have left your little girl's kotono string skirt Abandoning it, it is lost

Your little boy's tera'a bark belt

You have left it behind

3. The so'one tree clan woman Fana'ayome

Her son Derabore

His mother Moruame

Ibu Dawabo

4. His father Kibudobo man Hogebo

His mother Moruame

Their child whose name we call so sweetly

Derabore 


\section{Men's Song 26}

\section{Singers: Dunubu and Abuyu. Recorded 4 December 1984 at Hegeso village.}

This song makes use of the polysemy of the Foi word hua, which means 'struck' (from the verb $h u^{-}$, to strike, kill, hit); 'planted' (from the same verb, mohu-); and, with the addition of nasalisation on the $u$ (hũa), 'mother.' Crashing, rushing water strikes the stones in creek and river beds. Also, men must plant the stakes with which they construct fish dams across the mouths of small creeks. Finally, large bodies of water, like the Mubi, Baru, Yo' oro Rivers, and Lake Kutubu, are called ibu hũa, the 'mother' of waters, as in any particularly large specimen of any category (hence, a hũa 'mother of houses', i.e. the longhouse).

Hemomo'o is a detritus, and flotsam collects as it flows downstream. It also means, 'froth, scum', etc. The verb hubagia- means two things: (1) to push aside logs and flotsam as one paddles a canoe; (2) to spread fish poison in dammed water. This fine verse thus compresses the image of spreading fish poison in still water, with that of the man threading a canoe through debris-laden water. (See Weiner 1991:60, 83, 102-4.)

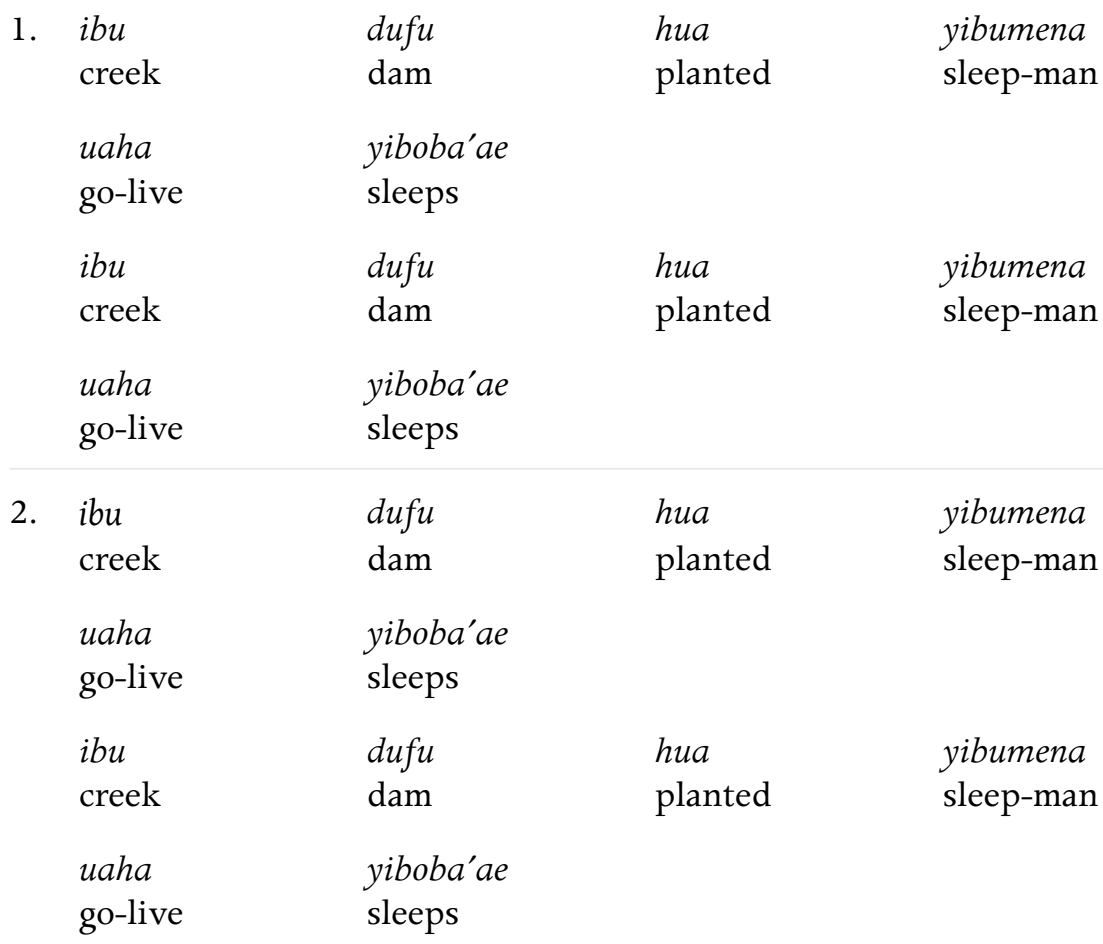


3. $i b u$

water

uaha

go-live

ibu

water

bereboba'ae

is lost
4. ibu

water

uaha

go-live

ibu

water dimani

rushing

yiboba'ae

sleeps

ãgu

swiftly hua

strikes

hua

strikes yibumena

sleep-man

yibumena

sleep-man

bereboba'ae

is lost

5. ibu

water

uaha

go-live

ibu

water hua

mother

yiboba'ae

sleeps

ka'asubagedia

crashing yibumena

sleep-man

yibumena

sleep-man

bereboba'ae

is lost

6. nami

hemomo'o

hubagia

yibumena

flotsam

remove

sleep-man

yiboba'ae

sleeps

ãgu

hua

yibumena

swiftly

mother

sleep-man

pig

ko'onomo

yo

$a b a-o$

Ko' ono

its

father, oh!

dawabo

dawabo

gesa

sawa

yo

$a b a-o$

$\operatorname{dog}$

Sawa

its

father, oh!

dawabo

dawabo 
7. nami

pig

dawabo

dawabo

gesa

$\operatorname{dog}$

dawabo

dawabo duni

many

yo

their

$a b a$

father

1. Near the fish dam where you habitually sleep

There you have gone to rest

Near the fish dam where you are wont to stay

There you have gone to sleep the night

2. Near the fish dam where you habitually sleep

There you have gone to rest

Near the fish dam where you are wont to stay

There you have gone to sleep the night

3. He who sleeps near the rushing water

There he silently sleeps

Near the rushing hissing water

Only the river's sound we hear

4. The man who sleeps near the sibilant water

He has gone to rest there

The soft crash of rushing water

But he is lost

5. He who removed the flotsam as he paddled

He has gone there to sleep

Near the splashing rushing water

He is lost

6. The father of the pig Ko' onobo

Dawabo

The father of the dog Sawa

Dawabo 
7. The man who cared for many pigs

Dawabo

He who cared for the dog Sawa

Dawabo

\section{Men's Song 27}

\section{Singers: Kora and Abeabo. ${ }^{10}$ Recorded 4 December 1984 at Hegeso village.}

The gentle up-and-down movement of a canoe as it moves through water is evoked in this song. (See Weiner 1991:99-101.)

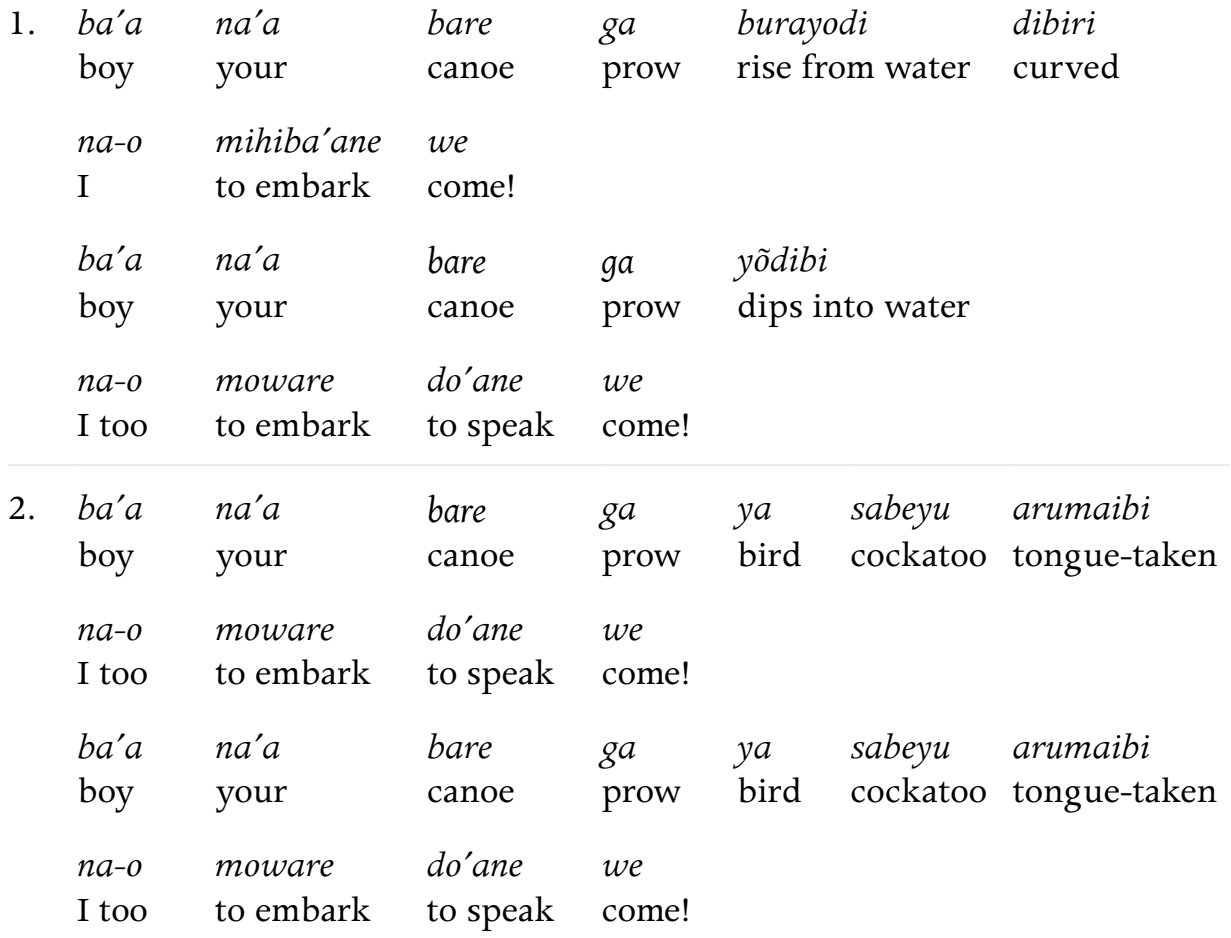

3-4. [verse 2 repeated two more times]

\footnotetext{
10 As well as being skilled singers and close friends, Kora Midibaru and Abeabo Waibo were my field assistants, helping me to translate many of the songs in this volume (Weiner 1991:ii, xiii).
} 


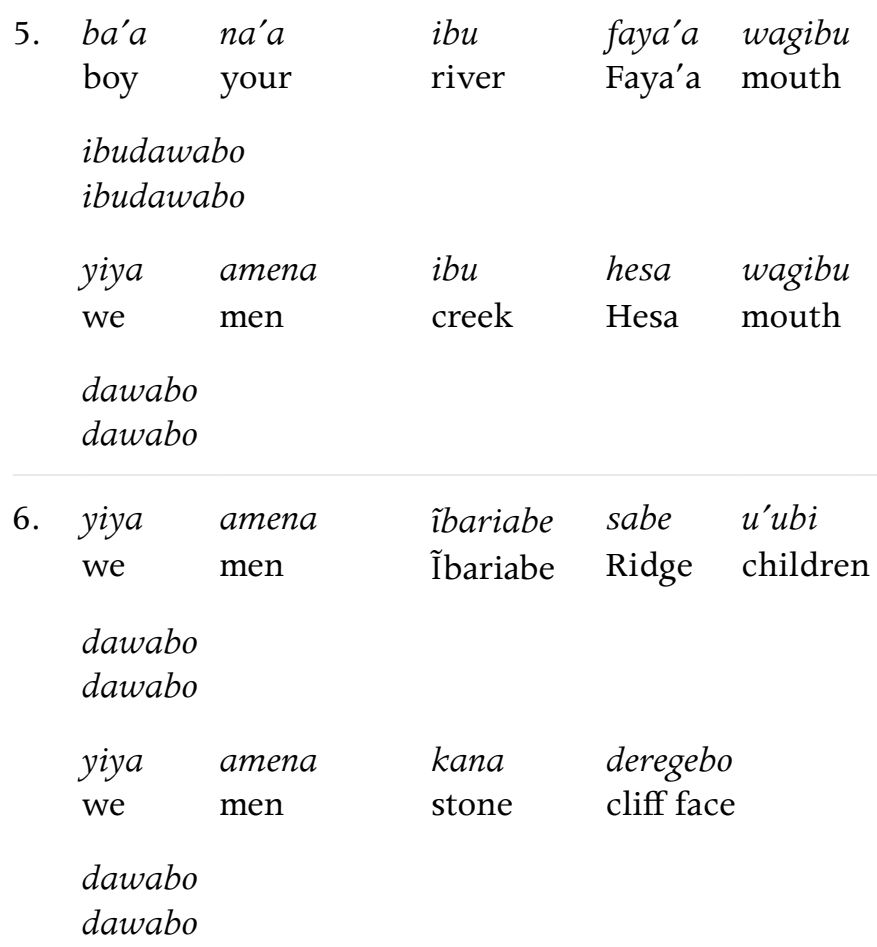

1. Boy, the curved prow of your canoe lifts gently from the water Come fetch me too

The bow of your canoe dips gracefully back into the water oh come and let me embark too!

2. Boy, your cockatoo-tongued canoe prow

Come and get me, I say!

Boy, your canoe prow as beautiful as the cockatoo's tongue I too want to get in your canoe

3-4. [verse 2 repeated 2 more times]

5. Boy, your Faya'a Creek flowing into the Mubi Ibu Dawabo

We are the men of the mouth of Hesa Creek

Dawabo 
6. We are the children of Ĩbariabe Hill

Dawabo

We are the men of the stone lined mountain

Dawabo

\section{Men's Song 28}

\section{Singers: Hasuabo and Kuri. Recorded 2 January 1985 at Hegeso village.}

This song was sung in memory of a Wage River man who migrated to Hegeso village and remained there for the rest of his life. His name was Ayamena, which literally means 'above man'. Like most Highlands men, he wore a knitted cap, and after his death, this cap was likened to a cassowary's crest. Denabuyu and Kinabo were Ayamena's mother and father respectively; Ayamena's name itself is not mentioned in the dawa.

1. togeganuga

cassowary crest

ira waboba

tree come

iburi yage

water drowned

aodiba

bush covered

2. ira

gua duru

tree

gua

fence

foraye

uboba'a

broken

has gone

masene

dogo

arrow

bundle

foroma uboba'a

broken + take has gone 


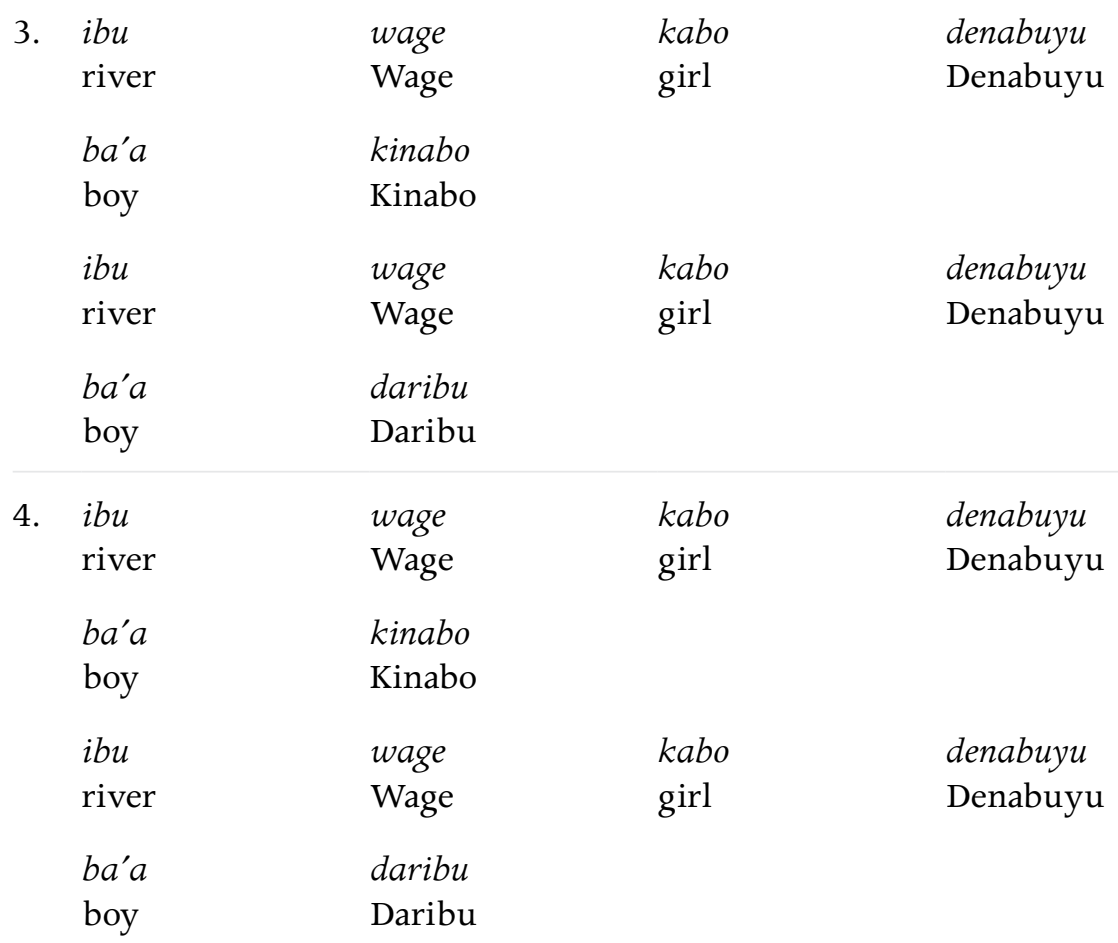

1. The man of the cassowary crest The bush has covered him over

Drowned in the river The trees have hidden him

2. The Highlands' gua tree fence Has been broken off

The Highlands's masene arrow bundle Has been snapped in two

3. The woman of the Wage River, Denabuyu The boy Kinabo

The woman of the Wage River, Denabuyu The boy Kinabo

4. The woman of the Wage River, Denabuyu The boy Kinabo

The woman of the Wage River, Denabuyu The boy Kinabo 


\section{Men's Song 29}

\section{Singers: Hasuabo and Kuri. Recorded 2 January 1985 at Hegeso village.}

A man's trees, flowers, and garden vegetables become prey to wild animals and birds and to furtive humans after he has died. The signs of life and regeneration of a man's plantings gradually are consumed, by animals or people as well as the bush itself, after the man has died.

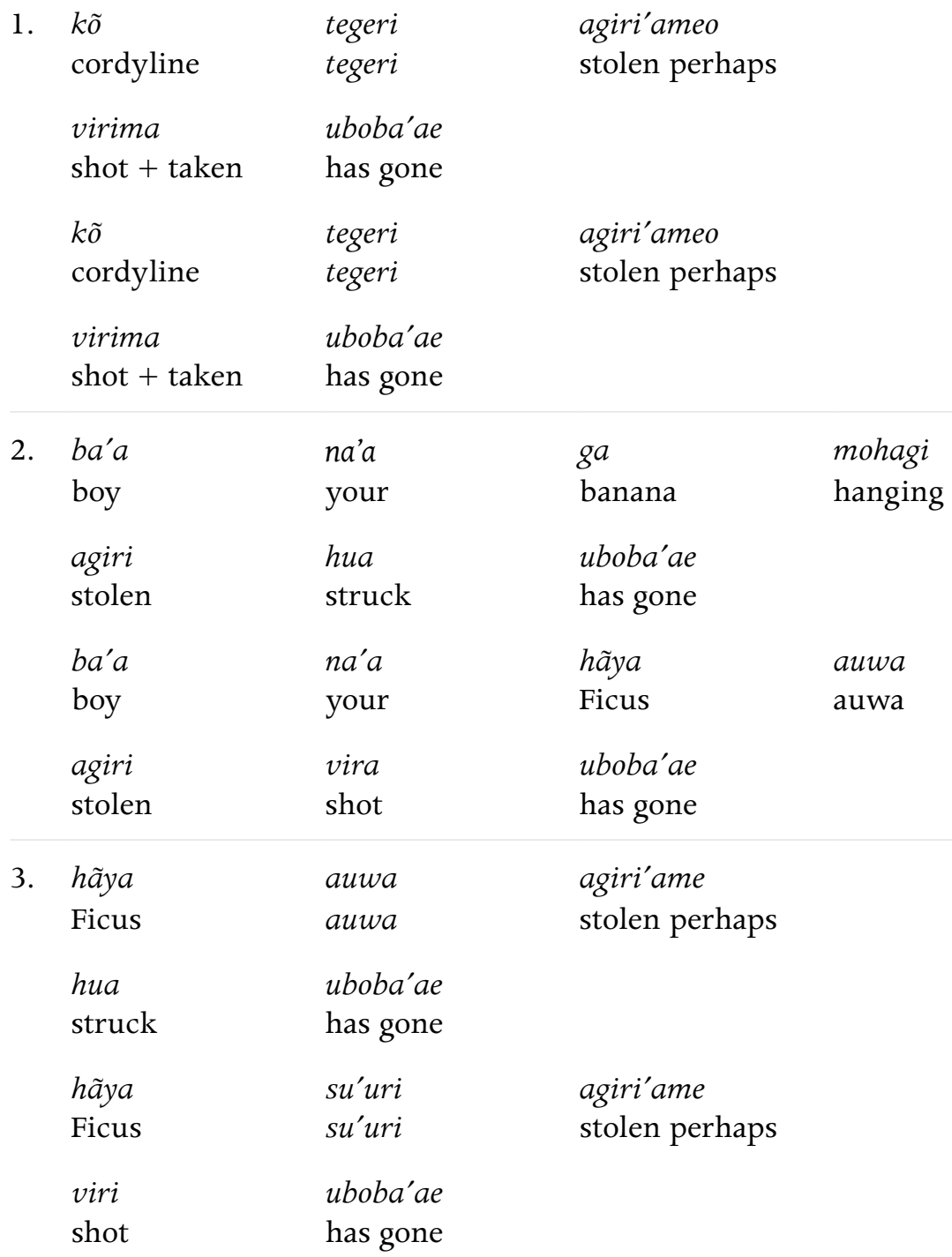


4. aya

sky

ya

bird

dawabo

dawabo

aya

sky

ya

bird

dawabo

dawabo unubu

flying fox

5. aya

sky

ya

unubu

bird

flying fox

dawabo

dawabo

aya

ya

gugabe

sky

bird

flying fox

dawabo

dawabo

1. Perhaps your tegeri cordyline has been stolen

They struck it and left

Perhaps your tegeri cordyline has been stolen

They struck it and left

2. Boy, your banana hanging there

Perhaps the flying foxes have eaten and stolen it

Boy, your auwa Ficus leaves

Perhaps the flying foxes have shot it and left

3. Your auwa Ficus leaves

They have struck them and left

Your su'uri Ficus leaves

They have shot them and left

4. The flying fox high in the sky

Dawabo

The sky bird, the flying fox

Dawabo 
5. The flying fox high in the sky

Dawabo

The sky bird, the flying fox

Dawabo

\section{Men's Song 30}

\section{Singers: Viya and Komo'o. Recorded 2 January 1985 at Hegeso village.}

When the subject of this song, Sega, was mortally ill, he was flown to the hospital in Mendi. He eventually was flown back to Pimaga, and he died in Hegeso. This song makes use of the aeroplane image. (See Weiner 1991:47; 2001:26.)

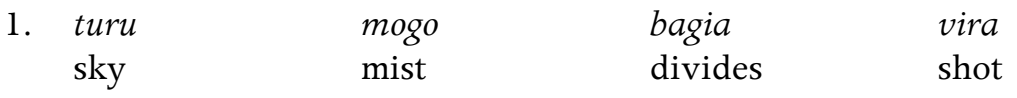

iribiwae

saw not

$\begin{array}{lll}\text { bare } & \text { uddia } & \text { vira } \\ \text { aeroplane } & \text { hummed } & \text { gone }\end{array}$

iribiwae

saw not

2. turu

mogo

bagia

vira

sky

mist

divides

shot

iribiwae

saw not

bare

ũdia

vira

aeroplane

hummed

gone

iribiwae

saw not

3. bare

ũdia

vira

aeroplane

droned

went

nabo

dibiwae

to me

said not 
Songs of the Empty Place

$\begin{array}{lll}\begin{array}{l}\text { bare } \\ \text { aeroplane }\end{array} & \begin{array}{l}\text { odia } \\ \text { droned }\end{array} & \begin{array}{l}\text { vira } \\ \text { went }\end{array} \\ \text { nabo } & \text { dibiwae } & \\ \text { to me } & \text { said not } & \end{array}$

$\begin{array}{llll}\text { 4. wa'aridobo } & \text { ka } & \text { hasobe } \\ \text { Wa'aridobo } & \text { woman } & \text { Hasobe } & \\ \text { ba'a } & \text { sega } & & \\ \text { boy } & \text { Sega } & \\ \text { ira } & \text { namani } & \text { dobo } & \text { yarogemo } \\ \text { tree } & \text { namani } & \text { clan } & \text { Yaroge } \\ \text { ba'a } & \text { fu'ubuĩ } & & \\ \text { boy } & \text { Fu'ubuĩ } & & \end{array}$

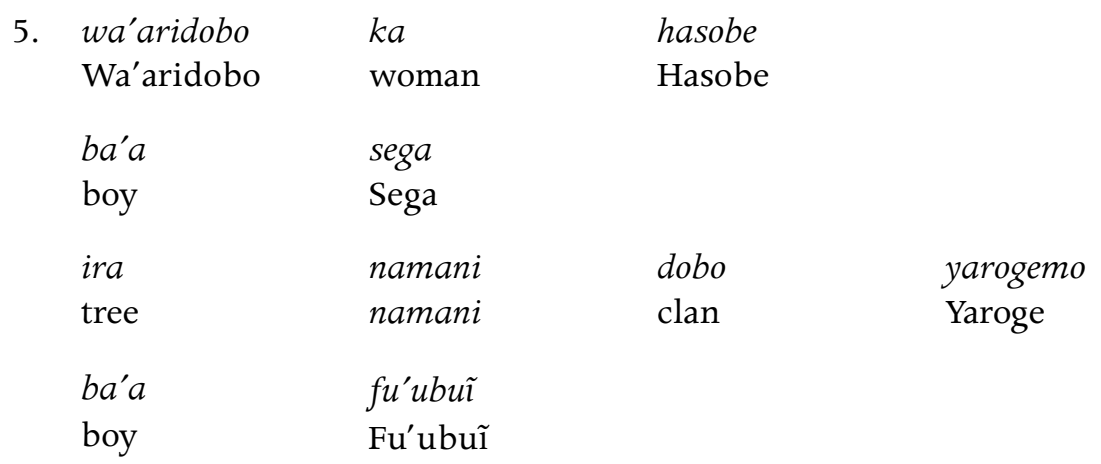

1. Through the cloud-covered mountains you flew But we did not see you

The aeroplane droned as it disappeared But we saw you not

2. Through the cloud-covered mountains you flew But we did not see you

The aeroplane droned as it disappeared But we saw you not

3. The aeroplane buzzed as it flew away But you said nothing to us 
The aeroplane hummed as it disappeared through the cloud

But to us you said nothing

4. The Wa' aridobo woman, Hasobe

Her son Sega

The clan of the namani tree, the man Yaroge

His son, Fu'u'ubi

5. The Wa' aridobo woman, Hasobe

Her son Sega

The clan of the namani tree, the man Yaroge

His son, Fu'u'ubi

\section{Men's Song 31}

\section{Singers: Viya and Komo'o. Recorded 2 January 1985 at Hegeso village.}

In January 1985 the Hegeso men held their pig-kill. This song, composed some months before by one of the Hegeso women, expressed the uncertainties that surround the planning of such a pig-kill. The verse concerning the bird feathers refers to the placing of such feathers in mens' headdresses.

1. ira

tree

dobo'owa

spoken of

ira

tree

dobo'owa

spoken of

2. sui

cane

togebe

is this it? nabu

casuarina

gugu'anegebe

will it flower?

\section{togebe}

is this it?

sonane

sonane

togebe

is this it? gugu'anegebe

will it flower?

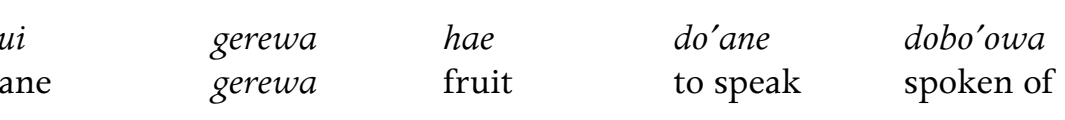


Songs of the Empty Place

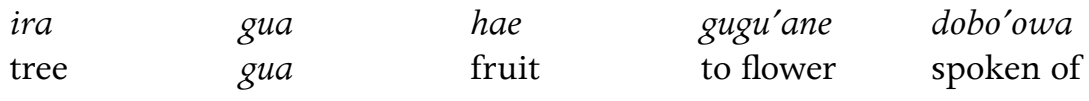

togebe

is this it?

\begin{tabular}{|c|c|c|c|c|}
\hline 3. & & furu & & ho'ane \\
\hline & & & feathers & to insert \\
\hline & dobo'owa & togebe & & \\
\hline & spoke of & is this it? & & \\
\hline & ya & garobo & & ho'ane \\
\hline & bird & garobo & feathers & to insert \\
\hline & dobo'owa & togebe & & \\
\hline & spoken of & is this it? & & \\
\hline 4. & amena & $i b u$ & faya'a & wagibu \\
\hline & men & river & Faya'a & mouth \\
\hline & dawabo & & & \\
\hline & dawabo & & & \\
\hline & amena & $i b u$ & hesa & tage \\
\hline & men & creek & Hesa & mouth \\
\hline & dawabo & & & \\
\hline & dawabo & & & \\
\hline 5. & amena & koroba & sabe & $u^{\prime} u b i-o$ \\
\hline & men & Koroba & Ridge $^{11}$ & children \\
\hline & dawabo & & & \\
\hline & dawabo & & & \\
\hline & amena & baiga & sabe & $u^{\prime} u b i$ \\
\hline & men & Baiga & Ridge $^{12}$ & children \\
\hline & dawabo & & & \\
\hline & dawabo & & & \\
\hline
\end{tabular}

11 Site of the Herebo longhouse.

12 Site of the Barutage longhouse. 
1. The casuarina tree that we have been speaking of Will it flower?

The flower of the sonane tree

Will it appear as we said it would?

2. Will the fruit of the gerewa cane

Appear as we spoke of?

Will the gua tree flower appear

That which we have been speaking of for so long?

3. The furu bird feathers that we wanted to plant

Is it these that we see before us?

The garobo bird feathers which we wanted to plant

Is it these here?

4. We are the men of the end of the Faya'a Creek

Dawabo

We are the men of the end of the Hesa Creek

Dawabo

5. We are the men of Koroba Ridge

Dawabo

We are the men of Baiga Ridge

Dawabo

\section{Men's Song 32}

\section{Singers: Viya and Komo'o. Recorded 2 January 1985 at Hegeso village.}

A man is angry at the birds who eat his bananas and other fruit. He addresses them, 'we didn't plant these things together; they're not yours.'

$\begin{array}{llll}\text { 1. ga } & \text { dõbe } & \text { hiri } & \text { bare } \\ \text { banana } & \text { dõbe } & \text { planted } & \text { that } \\ \text { yage } & \text { wae } & & \\ \text { ours } & \text { no } & & \end{array}$


Songs of the Empty Place

\begin{tabular}{|c|c|c|}
\hline $\begin{array}{l}\text { ira } \\
\text { tree }\end{array}$ & $\begin{array}{l}\text { bai } \\
\text { bai }\end{array}$ & $\begin{array}{l}\text { duru } \\
\text { fence }\end{array}$ \\
\hline yagemo & wae & \\
\hline ours & not & \\
\hline
\end{tabular}

2. $g a$

banana mahagi planted

yagemo ga wae

our belongs to not

ira onobo duru

tree onobo fence

yagemo ga wae

ours belongs to not

3. ira bai duru bare

tree bai fence that

yagemo wae

ours not

wãsia kamua hiri bare

pitpit kamua planted that

yagemo wae

ours not

4. $g a$

$\begin{array}{llll}\text { ga } & \text { dõbe } & \text { hiri } & \text { tore } \\ \text { banana } & \text { dôbe } & \text { planted } & \text { this }\end{array}$

yagemo mohobiwae

ours planted not

ira bai duru tore

tree bai fence this

yagemo wae

ours not

5. yiya

we

amena ya

ganiyu

men

bird

ganiyu

dawabo

dawabo 
$\begin{array}{llll}\text { yiya } & \text { amena } & \text { ya } & \text { dẽse } \\ \text { we } & \text { men } & \text { bird } & \text { dẽse }\end{array}$

dawabo

dawabo

6. yiya

amena ya

ga

nobo

we

men

bird

banana

eaten

dawabo

dawabo

yiya

amena

ya

ganiyu

we

men

bird

ganiyu

dawabo

dawabo

1. These dobe bananas here

We didn't plant them

This fence of bai wood around my garden

You didn't help me make it

2. This mahagi banana here

It is not ours

This onobo tree wood fence

It doesn't belong to us

3. This bai wood fence

It is not the two of ours

This kamua pitpit here

It is not ours

4. This dobe banana here

We didn't plant is together

This bai wood fence

We didn't build it together

5. We are the ganiyu birds

Dawabo

We are the dẽse parrots

Dawabo 
6. We are the banana eating birds

Dawabo

We are the ganiyu birds

Dawabo

\section{Men's Song 33}

\section{Singers: Sega and Abeabo. Recorded 31 December 1983 at Hegeso village by Kora Midibaru.}

A woman from Ibutaba longhouse, east of Hegeso, composed this song, in which she complains about the unfair treatment she has been subject to at the hands of her husband. The second verse refers to the beatings she has endured with certain hardwood sticks her husband used.

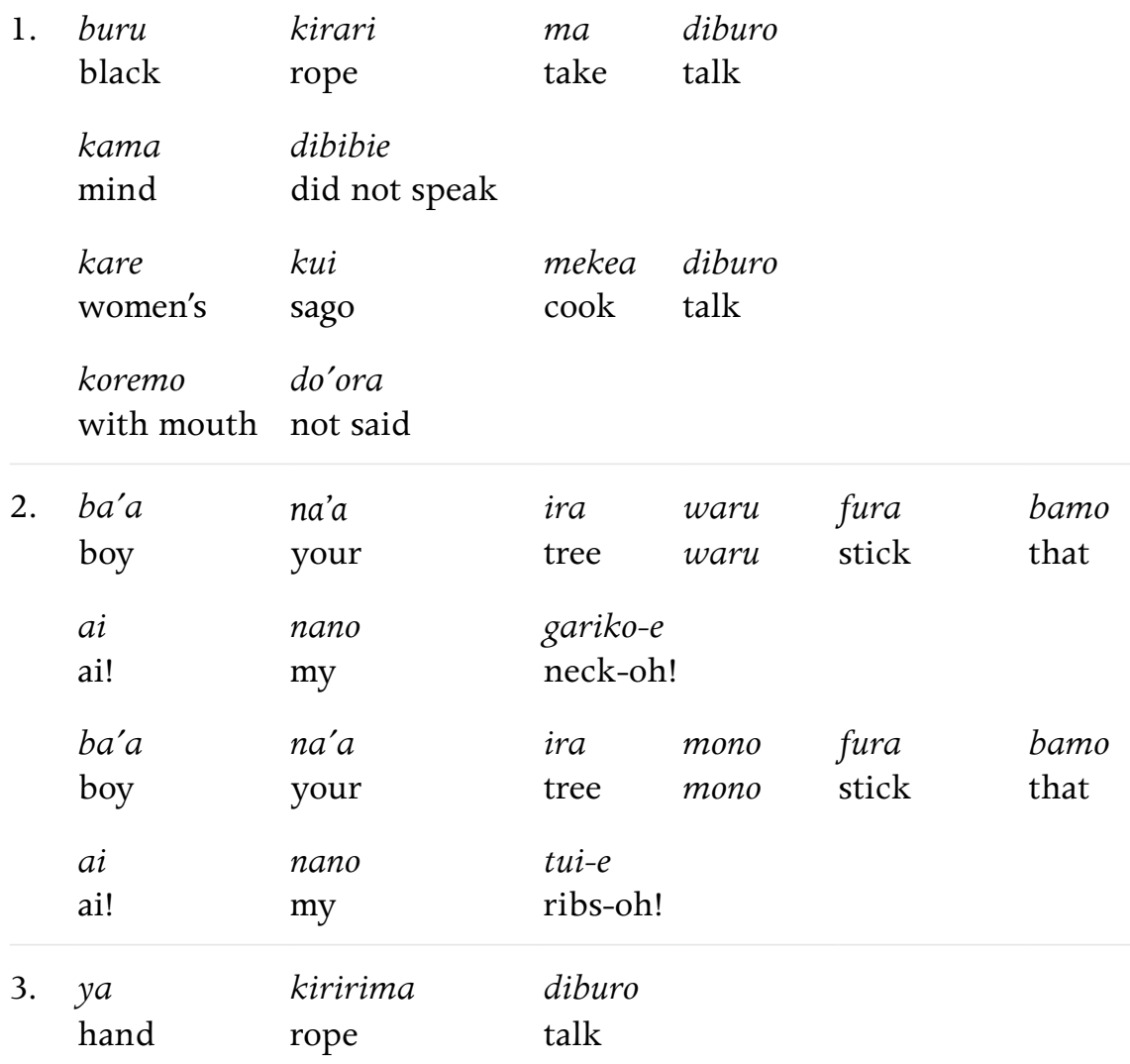




$\begin{array}{llll}\begin{array}{l}\text { kama } \\ \text { mind }\end{array} & \begin{array}{l}\text { dibubi'e } \\ \text { did not speak }\end{array} & \\ \text { kare } & \text { kui } & \begin{array}{l}\text { mekea } \\ \text { cook }\end{array} & \begin{array}{l}\text { diburo } \\ \text { talk }\end{array} \\ \text { somen's } & \text { sago } & & \\ \text { dase } & \text { do'abobi'o } & & \\ \text { talk } & \text { should have said } & \end{array}$

\begin{tabular}{|c|c|c|c|}
\hline $\begin{array}{l}\text { 4. oro } \\
\text { bamboo }\end{array}$ & $\begin{array}{l}\text { yerebi } \\
\text { yerebi }\end{array}$ & $\begin{array}{l}\text { dobo } \\
\text { clan }\end{array}$ & $\begin{array}{l}b a^{\prime} a \\
\text { boy }\end{array}$ \\
\hline
\end{tabular}

$\begin{array}{ll}b a^{\prime} a & \text { guma } \\ \text { boy } & \text { Guma }\end{array}$

$\begin{array}{lllll}\begin{array}{l}k u i \\ \text { sago }\end{array} & \begin{array}{l}\text { inibi } \\ \text { cooked-eaten }\end{array} & \begin{array}{l}\text { dobo } \\ \text { clan }\end{array} & \begin{array}{l}\text { kabo } \\ \text { girl }\end{array} & \begin{array}{l}\text { isanoka } \\ \text { Isanoka }\end{array} \\ b a^{\prime} a & \text { herebo } & & & \\ \text { boy } & \text { Herebo } & & & \end{array}$

\begin{tabular}{|c|c|c|c|}
\hline $\begin{array}{ll}\text { 5. } & \text { kui } \\
\text { sago }\end{array}$ & $\begin{array}{l}\text { inibi } \\
\text { cooked-eaten }\end{array}$ & $\begin{array}{l}\text { dobo } \\
\text { clan }\end{array}$ & $\begin{array}{l}\text { kabo } \\
\text { girl }\end{array}$ \\
\hline
\end{tabular}

\begin{tabular}{|c|c|c|c|c|c|}
\hline $\begin{array}{l}b a^{\prime} a \\
\text { boy }\end{array}$ & $\begin{array}{l}\text { herebo } \\
\text { Herebo }\end{array}$ & & & & \\
\hline $\begin{array}{l}\text { kui } \\
\text { sago }\end{array}$ & $\begin{array}{l}\text { inibi } \\
\text { cooked-eaten }\end{array}$ & $\begin{array}{l}\text { dobo } \\
\text { clan }\end{array}$ & $\begin{array}{l}\text { kabo } \\
\text { girl }\end{array}$ & $\begin{array}{l}\text { mege } \\
\text { only }\end{array}$ & $\begin{array}{l}b a-o \\
\text { that }\end{array}$ \\
\hline $\begin{array}{l}b a^{\prime} a \\
\text { boy }\end{array}$ & $\begin{array}{l}\text { guma } \\
\text { Guma }\end{array}$ & & & & \\
\hline
\end{tabular}

1. You did not tell me to hold the rope of the black pig How should I know what you want of me?

You didn't tell me to cook afternoon sago

How can I tell what your thoughts are?

2. Boy, your waru tree stick there

Oh, my poor neck!

Boy, your mono tree stick there

Ai, my poor rib-cage!

3. To take the pig's rope with my hands, you did not say 
You didn't tell me what you were thinking

To cook afternoon sago, you did not say

You should have told me with words

4. The man of the yerebi bamboo clan, Baihaihubu

His son, Guma

The Cooked Sago clan woman Isanoka

Her son, Herebo

5. The Cooked Sago clan woman Isanoka

Her son Herebo

The Cooked Sago woman only

Her son Guma

\section{Men's Song 34}

\section{Singers: Ayadobo and Damu. Recorded 31 December 1983 at Hegeso village by Kora Midibaru.}

This is a common sago melody. The two men who sang this song, instead of calling out the name of a commemorated man in the dawa, sang 'sago clan', as a rendition of the subject of this woman's sago song.

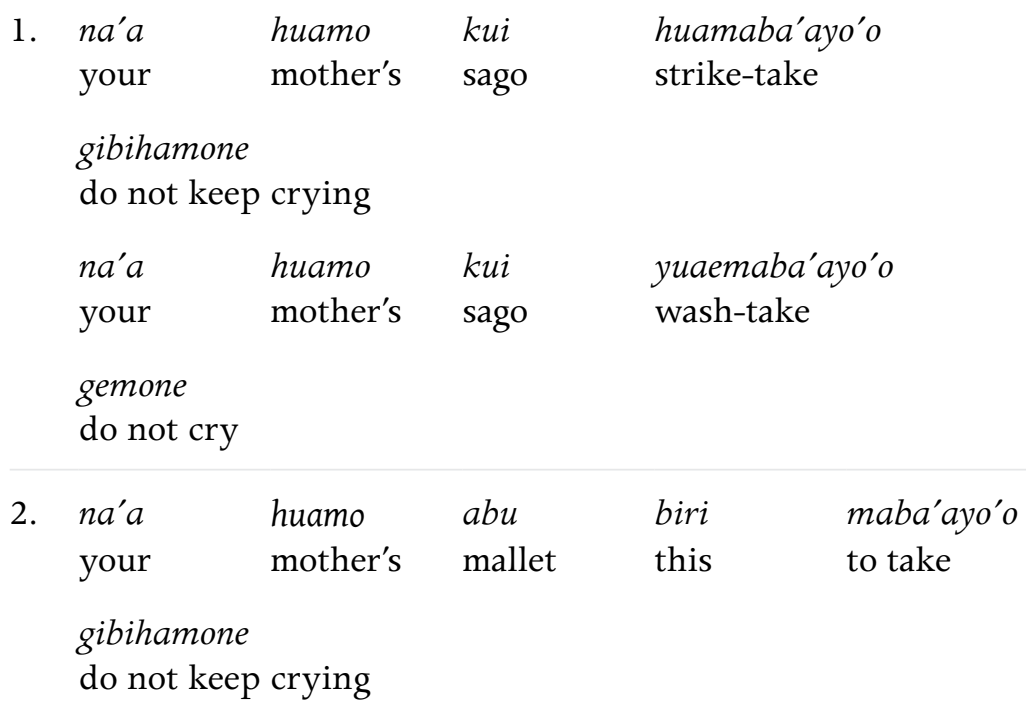




\begin{tabular}{|c|c|c|c|}
\hline $\begin{array}{l}n a^{\prime} a \\
\text { your }\end{array}$ & $\begin{array}{l}\text { huamo } \\
\text { mother's }\end{array}$ & $\begin{array}{l}k u i \\
\text { sago }\end{array}$ & $\begin{array}{l}\text { huamaba'ayo'o } \\
\text { strike-take }\end{array}$ \\
\hline $\begin{array}{l}\text { mone } \\
\text { not cry }\end{array}$ & & & \\
\hline
\end{tabular}

3. na'a kuamo gesamaba'ayo'o

your mother's sago remove pith

hirabumone

do not cry

na'a huamo kui ya forayemaba'ayo'o

your mother's sago hand snap-take

gibihamone

do not keep crying

4. amena kui hebo

men sago hebo

dawarabo

dawabo

amena kui kenege

men sago mid-rib

ibuhebo

dawabo

5. amena kui hebo

men sago hebo

dawarabo

dawabo

$\begin{array}{lll}\text { amena } & \text { kui } & \text { kenege } \\ \text { men } & \text { sago } & \text { mid-rib }\end{array}$

ibuhebo

dawabo 
1. Child, let your mother beat her sago

Don't keep crying

Child, let your mother wash her sago

Do not cry

2. Let your mother take her sago mallet

Child, stop crying

Let your mother keep pounding sago

Child, do not cry

3. Child, let your mother remove the pith

Do not keep crying

Let your mother snap her wrists

Do not cry so

4. We are the men of the hebo Sago clan

Dawarabo

We are the men of the kenege Sago clan

Ibu Hebo

5. We are the men of the hebo Sago clan

Dawarabo

We are the men of the kenege Sago clan

Ibu Hebo

\section{Men's Song 35}

\section{Singers: Tari and Abuyu. Recorded 31 December 1983 at Hegeso village by Kora Midibaru.}

This is also a common woman's sago song. A woman's child cries out 'like a hornbill' to be fed while she is busy making sago. As with men's song 34, this sorohabora is not a commemorative song per se, but an untransformed rendition of a common woman's sago song. In the dawa, the men sing 'hornbill clan' to mark the imagery the woman uses for her child. The verb ending used in the second line of each couplet, -yebe, is an interrogative particle with sarcastic overtones. The woman is thus singing, 'So, you are crying out heartily that I have not given you sago. What do you think I do all day?!' (See Weiner 1991:154.) 

1. wana'ari kui migi'orebo'o
mid-day sago have not given
dibuyebe
are you saying?
kare kui migi'orebo'o
women's sago have not given
tawadibuyebe
are you complaining?

2. kare

kui

migi'orebo'o

women's

sago

have not given

odibuyebe

are you calling out?

tãbura kui

bamboo filled sago

migi'orebo'o

have not given

tawadibuyebe

are you complaining?

3. tãbura kui

bamboo filled sago

migi'orebo'o

have not given

hirabubuyebe

are you crying?

$\begin{array}{lll}\text { kare } & k u i & \text { migi'orebo'o } \\ \text { women's } & \text { sago } & \text { have not given }\end{array}$

dibuyebe

are you saying?

4. yiya

amena ya

ware

we

men

bird

hornbill

dawabo

dawabo

yiya

amena

men

ya

weigo

we

bird

hornbill

dawara'abo

dawabo 
5. yiya

we

dawabo

dawabo

yiya

we

amena

men

dawara'abo

dawabo amena ya

bird

ware

hornbill

ya

bird

weigo

hornbill

1. So I haven't given you your mid-day sago Is that what you think you're telling me?

So I haven't given you your evening sago Is that what you're complaining about?

2. I haven't given you your evening sago

Is that why your calling out to me?

Sago cooked in a new bamboo tube you haven't received

Is that what I hear you complaining about?

3. Your new bamboo cooked sago you haven't eaten yet

Is this what you're crying about?

Your evening sago you haven't eaten yet

Is this what you're saying to me?

4. We are the men of the hornbill

Dawabo

We are the men of Ayayewego, the hornbill

Dawara'abo

5. We are the men of the hornbill

\section{Dawabo}

We are the men of Ayayewego, the hornbill

Dawara'abo 


\section{Men's Song 36}

\section{Singers: Kusabuyu and Webirabo. Recorded 31 December 1983 at Hegeso village by Kora Midibaru.}

This song likens the deceased Hegeso headman Iriharabu to a bird with a broken wing, which crippled, falls to earth.

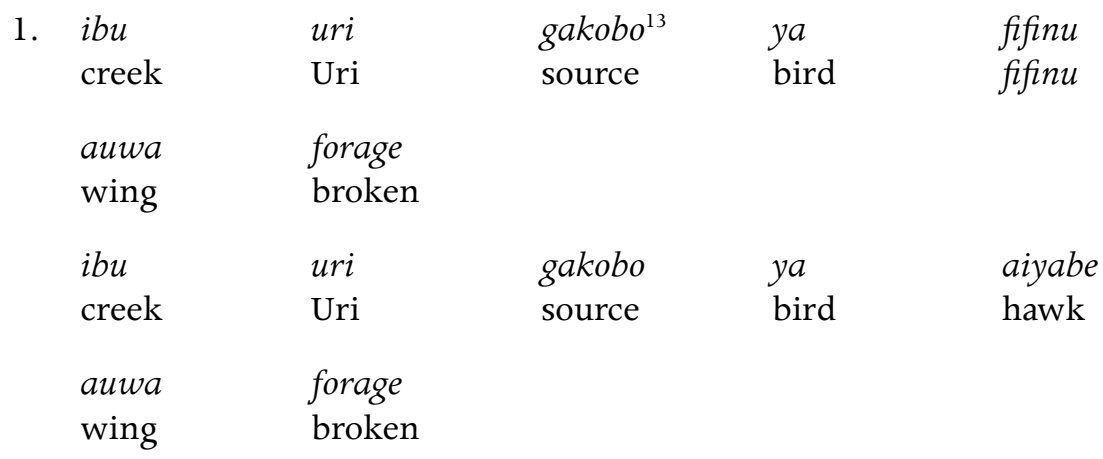

2. $i b u$ uri ga tegare

creek

Uri

source

ko'oya tree

foraboba'ae

cut down

$\begin{array}{lllll}\begin{array}{l}\text { ibu } \\ \text { creek }\end{array} & \begin{array}{l}\text { uri } \\ \text { Uri }\end{array} & \begin{array}{l}\text { ga } \\ \text { source }\end{array} & \begin{array}{l}\text { ira } \\ \text { tree }\end{array} & \begin{array}{l}\text { fore } \\ \text { large }\end{array} \\ \begin{array}{l}\text { daria } \\ \text { uprooted }\end{array} & \begin{array}{l}\text { uboba'ae } \\ \text { gone }\end{array} & & & \end{array}$

3. ibu

kumagi

ya

aiyabe

creek

Kumagi

bird

hawk

viramaiba'ae

shot-taken

$\begin{array}{llll}\begin{array}{lll}\text { ibu } \\ \text { creek }\end{array} & \text { uri } & \text { ya } & \text { fifinu } \\ & \text { uri } & \text { bird } & \text { fifinu } \\ \text { vira } & \text { uboro } & & \\ \text { shot } & \text { gone } & & \end{array}$

13 Gakobo is a contraction of ga korobo: 'source upstream'. The source of the Uri Creek is 'upstream', in Ayamo country. This song, like men's song 6, is about the former headman Iraharabo of Hegeso, and makes use of the same imagery. 


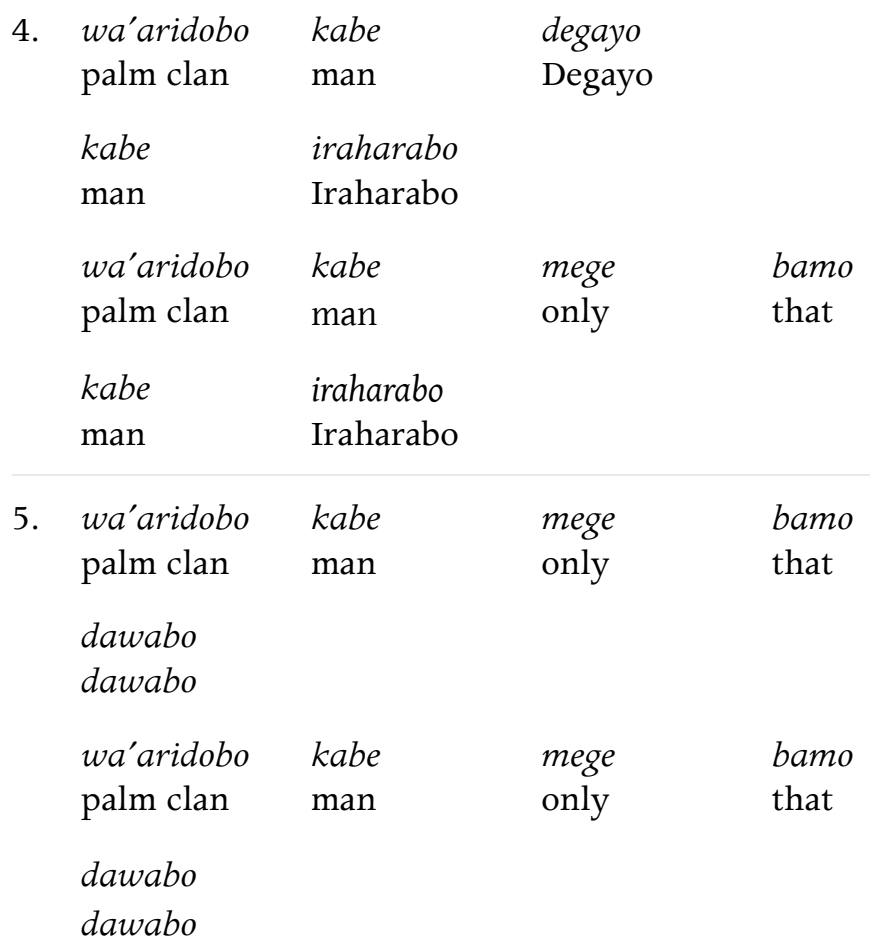

1. At the source of the Uri Creek, the fifinu bird Broken winged

At the head of the Uri Creek, the hawk Cripple winged

2. At the source of the Uri Creek, the ko'oya tree Cut down

At the origin of the Uri water, the large tegare tree The wind has uprooted it

3. At the Kumagi Creek, the hawk Long time shot

At the Uri Creek, the fifinu bird Shot and taken

4. The man of the $w a^{\prime}$ ari palm clan, Degayo His son, Iraharabo 
The lonely man of the $w a^{\prime}$ ari palm clan

Iraharabo

5. This man only of the Wa'aridobo clan

Dawabo

This man only of the Wa'aridobo clan

Dawabo

\section{Men's Song 37}

\section{Singers: Sega and Abeabo. Recorded 31 December 1983 at Hegeso village by Kora Midibaru.}

Highlands men cover their pearl shells with red ochre. The woman singing of the dead man Terewaro, a Highlander who came to live in a Foi village, remembered seeing his red pearl shells and composed this song.

$\begin{array}{llll}\begin{array}{l}\text { 1. } \begin{array}{l}\text { gomo } \\ \text { my }\end{array} \\ \text { ochre }\end{array} & \begin{array}{l}\text { hare } \\ \text { red }\end{array} & \begin{array}{l}\text { dogo } \\ \text { bundle }\end{array} \\ \text { removed } & & & \\ \text { nomo } & \text { gi } & \text { damani } & \text { dogo } \\ \text { my } & \text { ochre } & \text { red } & \text { bundle } \\ \text { fisige } & & & \\ \text { removed } & & \text { dogo } & \\ \text { gi } & \text { bundle } & \\ \text { ochre } & \text { red } & & \\ \text { fisige } & & & \text { damani } \\ \text { removed } & & \text { gi } & \text { dogo } \\ \text { ba'a } & \text { na'a } & \text { ochre } & \\ \text { boy } & \text { your } & & \text { bundle } \\ \text { fisige } & & & \end{array}$




$\begin{array}{llll}\begin{array}{l}\text { 3.mena } \\ \text { men }\end{array} & \begin{array}{l}\text { ibu } \\ \text { river }\end{array} & \begin{array}{l}\text { wage } \\ \text { Wage }\end{array} & \begin{array}{l}\text { habu } \\ \text { lived }\end{array} \\ \begin{array}{l}\text { dawabo } \\ \text { dawabo }\end{array} & & & \\ \text { amena } & \text { duma } & \text { dira } & \text { wagibu } \\ \text { men } & \text { mountain } & \text { Dira } & \text { ending } \\ \text { dawabo } & & & \\ \text { dawabo } & & & \\ \text { yiya } & \text { amena } & \text { ba'a } & \text { terewaro } \\ \text { we } & \text { men } & \text { boy } & \text { Terewaro } \\ \text { dawabo } & & & \\ \text { dawabo } & & & \text { terewaro } \\ \text { yiya } & \text { amena } & \text { ba'a } & \text { Terewaro } \\ \text { we } & \text { men } & \text { boy } & \\ \text { dawabo } & & & \end{array}$

1. My bundle of red ochre

Has been removed

My parcel of red ochre

Has been taken

2. The red ochre bundle

Taken

Boy, your red ochre parcel

Removed

3. The men who lived near the Wage River

Dawabo

The men who live at the end of Mt Dira

Dawabo

4. We are Terewaro's men

Dawabo

We are Terewaro's men

Dawabo 


\section{Men's Song 38}

\section{Singers: Memene and Abeabo. Recorded 16 March 1988 at Hegeso village.}

This song commemorates all the headmen who died in Hegeso's recent past.

The places referred to are spots owned by previous Hegeso headmen.

1. hiba'aweĩ merabe

Hiba'aweĩ harbour

aodoboba'ae

bush covered

$\begin{array}{llll}\text { nomo } & \text { ibu } & \text { faya'a } & \text { geno } \\ \text { my } & \text { river } & \text { Faya'a } & \text { riverbend }\end{array}$

kigiboba'ae

tree covered

2. nomo

my

ira

fiwa

dera

forabi'ae

fallen

$\begin{array}{llll}\text { nomo } & \text { ira } & \text { furabo } & \text { dera } \\ \text { my } & \text { tree } & \text { furabo } & \text { that }\end{array}$

foramaibi'ae fallen down

3. nomo

$k o s a^{\prime} a$

buru

$g a$

merabe

my

Ficus

black

base

harbour

kigiboba'a

tree covered

$\begin{array}{lllll}\text { nomo } & \text { ira } & \text { furubu } & \text { ga } & \text { merabe } \\ \text { my } & \text { tree } & \text { furubu } & \text { base } & \text { harbour }\end{array}$

aodoboba'a

bush covered 


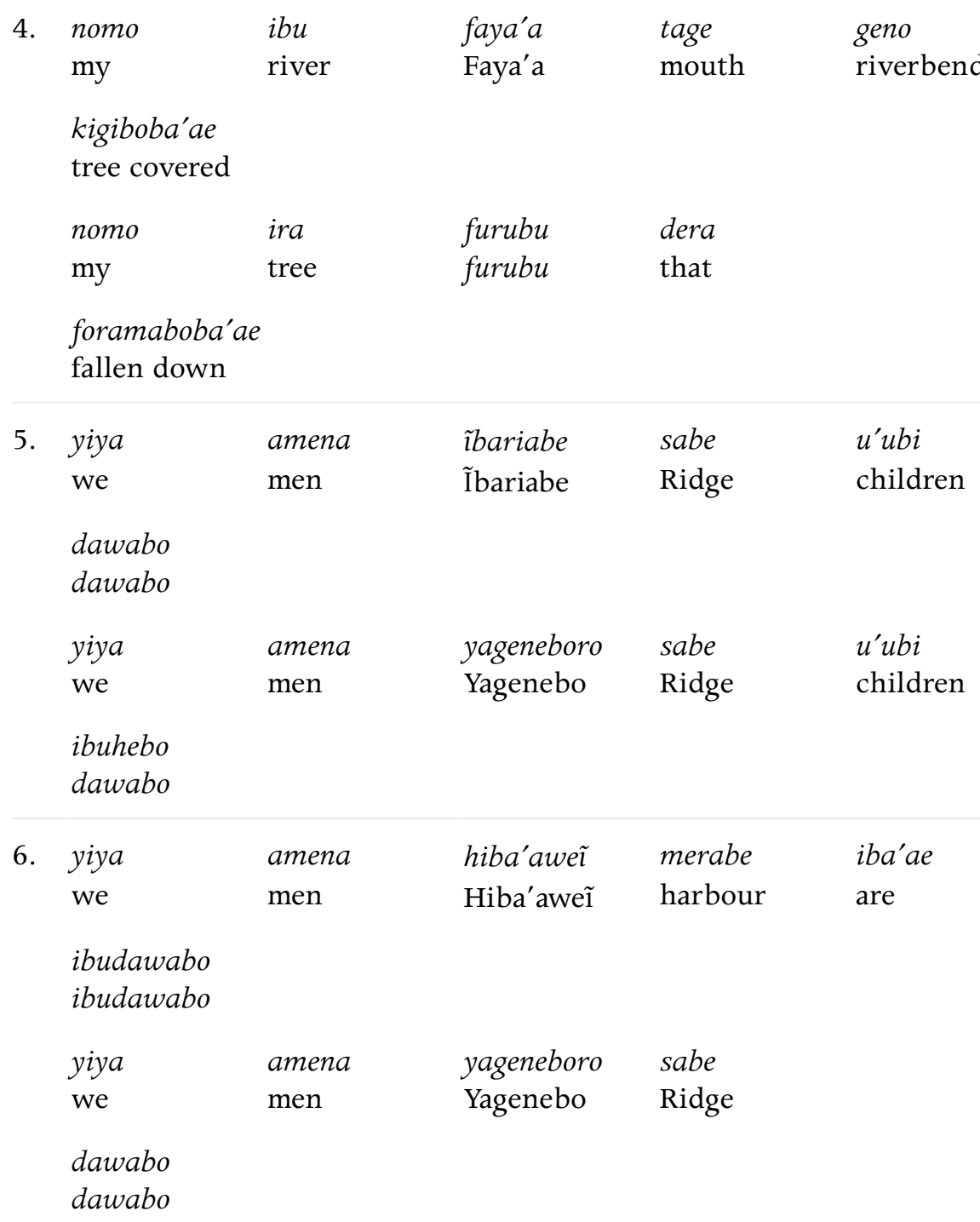

1. Hiba'aweĩ Harbour

The bush has hidden it

My Faya'a Creek whirlpool

The trees have covered it over

2. My fiwa tree there

Has fallen by itself 
My furabo tree there

Has fallen down

3. My harbour near the base of the kosa'a buru tree

The forest has reclaimed it

My harbour near the base of the furubu tree

The bush has obliterated it

4. The still water near the mouth of the Faya'a

The forest has taken it back

My furubu tree there

Has fallen down

5. We are the children of Ĩbariabe Ridge

Dawabo

We are the children of Yegenebo Ridge

Ibu hebo

6. We are the men of Hiba'aweĩ Harbour

Ibu Dawabo

We are the men of Yagenebo Ridge

Dawabo

\section{Men's Song 39}

\section{Singers: Kora and Abeabo. Recorded 16 March 1988 at Hegeso village.}

Kora heard his wife's mother singing this song. She had married the man Waria as an aged widow, and he used to beat her repeatedly, claiming she was no good for anything. The woman refers to the nettles she must rub against her brusied skin and the walking stick she must use because of her sore limbs. (See Weiner 1991:142-44.)

$\begin{array}{lllll}\text { 1. nane } & \begin{array}{l}\text { yengi } \\ \text { nettles }\end{array} & \begin{array}{l}\text { baya'a baya'a dogo bundle } \\ \text { I }\end{array} & \begin{array}{l}\text { hua } \\ \text { mother }\end{array} & \begin{array}{l}\text { iyo'o } \\ \text { am }\end{array} \\ \text { ba'a } & n a^{\prime} a & \text { dibiyebe } & \\ \text { boy } & \text { you } & \text { not saying? }\end{array}$


Songs of the Empty Place

$\begin{array}{llllll}\text { nane } & \text { yengi } & \text { fagena } & \text { dogo } & \text { hua } & \text { iyo'o } \\ \text { I } & \text { nettles } & \text { fagena } & \text { bundle } & \text { mother } & \text { am }\end{array}$

dibiyebe

not saying?

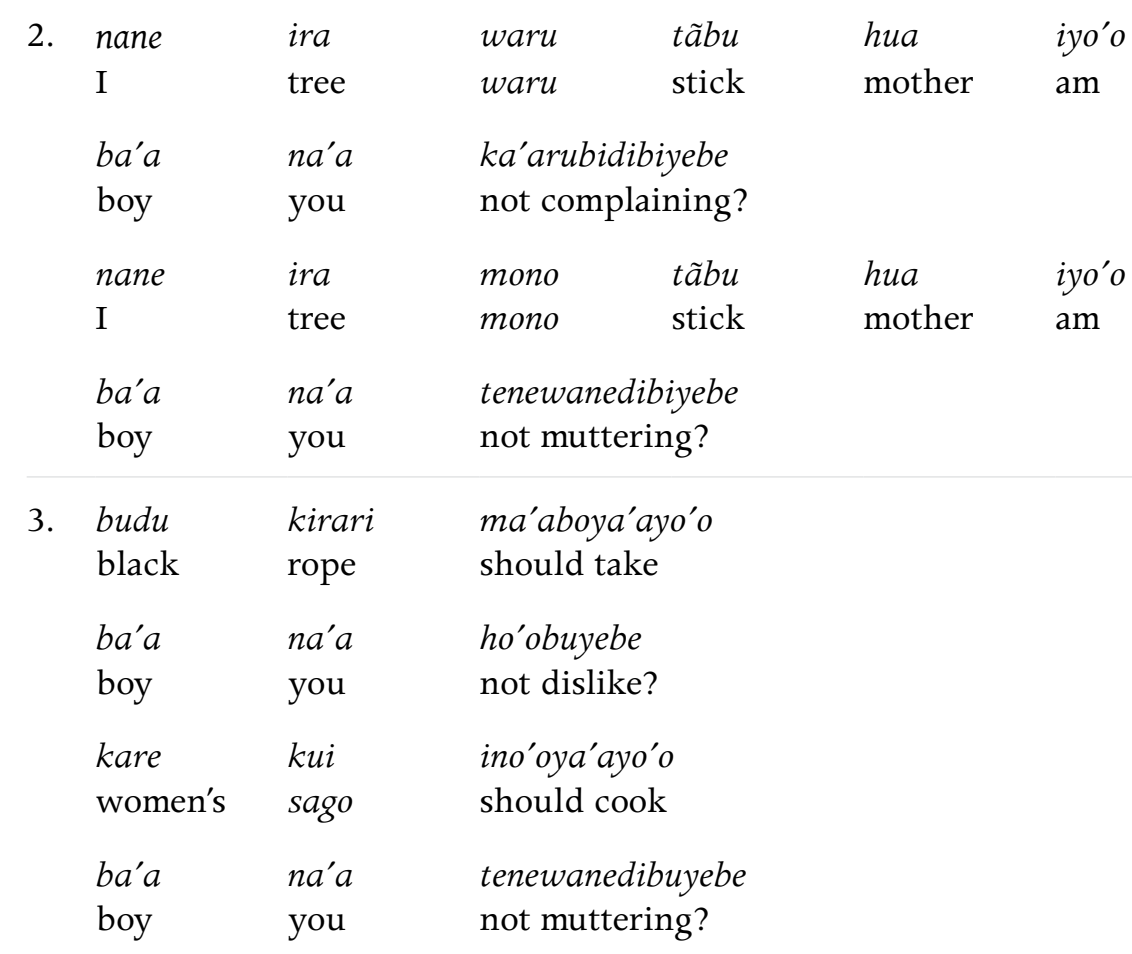

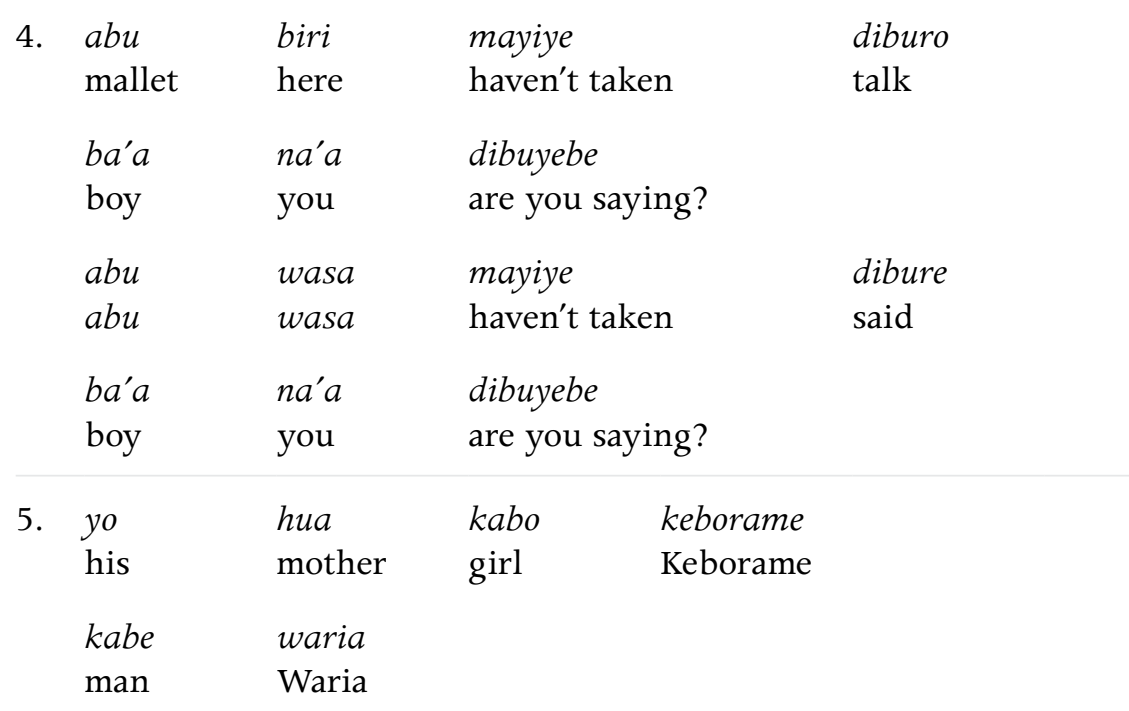




$\begin{array}{lllll}\begin{array}{l}\text { yo } \\ \text { his }\end{array} & \begin{array}{l}\text { hua } \\ \text { mother }\end{array} & \begin{array}{l}\text { ka } \\ \text { woman }\end{array} & \begin{array}{l}\text { mege } \\ \text { only }\end{array} & \begin{array}{l}\text { bamo } \\ \text { that }\end{array} \\ \begin{array}{l}\text { kabe } \\ \text { man }\end{array} & \begin{array}{l}\text { waria } \\ \text { Waria }\end{array} & & \\ \end{array}$

6. kibudobo kabe

Kibudobo man Tonebo

$\begin{array}{llll}\begin{array}{l}\text { kabe } \\ \text { man }\end{array} & \text { waria } & & \\ \text { Wo } & \text { hua } & \text { kabo } & \text { keborame } \\ \text { his } & \text { mother } & \text { girl } & \text { Keborame }\end{array}$

kabe yamagi

man Yamagi

1. My parcel of stinging nettles I carry Now what do you say to me?

I carry my little package of fagena nettles

Boy, what do you say about me now?

2. I am the mother of the waru wood walking stick

Boy, are you criticising me now?

I am the mother of the mono wood walking stick

Are you muttering under your breath about me?

3. So, I am not taking the rope of the black pig

Is that what you dislike about me?

Evening sago I am unable to cook

Is that what you are swearing about under your breath?

4. I haven't taken my sago mallet

Come now boy, is that what you are saying?

I haven't taken my sago hammer

Is that what you are saying?

5. His mother, the woman Keborame

The man Waria

His mother, the only woman

The man Waria 
6. The Kibudobo man, Tonebo

His son, Waria

His mother, the woman Keborame

Her son, Yamagi

\section{Men's Song 40}

\section{Singers: Sega and Kora. Recorded October 1982 at Hegeso village by Kora Midibaru.}

Men themselves - sadly, a dead man's own clansmen - are most instrumental in obliterating the signs of that man's productive life after his death, as this song alludes to. (See Weiner 1991:106-8.)

1. $b a^{\prime} a$

na'a yebibu ibu

boy your Yebibu creek

aginoba'aye

let another steal it

$\begin{array}{llll}b a^{\prime} a & n a^{\prime} a & \text { yefua } & \text { duma } \\ \text { boy } & \text { your } & \text { Yefua } & \text { mountain }\end{array}$

aodoba'aye

let bush cover it

2. ba'a na'a yebibu ibu

boy your Yebibu creek

aginoba'aye

let another steal it

ba'a na'a yefua duma

boy your Yefua mountain

aodoba'aye

let bush cover it

3. na'a huamo ibu sumaniyu

your mother's creek Sumaniyu

ibu aginoboba'ae

creek stolen eaten 
ba'a bamo yahadenabo

boy that Yahadenabo

ibu aodoba'aye

water let bush cover it

4. $b a^{\prime} a$ na'a ibu agegenebo

boy your creek Agegenebo

ibu aodoba'aye

creek let bush cover it

$b a^{\prime} a \quad n a^{\prime} a$ yebibu ibu

boy your Yebibu creek

ira waba'aye

tree let come

5. ba'a na'a sonobo duma

boy your Sonobo mountain

aodoboba'ae

bush covered

$\begin{array}{llll}b a^{\prime} a & n a^{\prime} a & \text { yefua } & \text { duma } \\ \text { boy } & \text { your } & \text { Yefua } & \text { mountain }\end{array}$

kigiboba'ae

tree covered

$\begin{array}{llllll}\text { 6. } \begin{array}{l}\text { oro } \\ \text { bamboo }\end{array} & \begin{array}{l}\text { yerebi } \\ \text { yerebi }\end{array} & \begin{array}{l}\text { dobo } \\ \text { clan }\end{array} & \begin{array}{l}\text { ba'a } \\ \text { boy }\end{array} & \begin{array}{l}\text { hamabo } \\ \text { Hamabo }\end{array} \\ \begin{array}{l}\text { kabe } \\ \text { kabusa }\end{array} & \begin{array}{l}\text { Kabusa } \\ \text { Kan }\end{array} & & & \\ \text { oro } & \text { yerebi } & \text { dobo } & \text { kabe } & \text { mege } & \text { bamo } \\ \text { bamboo } & \text { yerebi } & \text { clan } & \text { man } & \text { only } & \text { this } \\ \text { ba'a } & \text { dãwano } & & & & \\ \text { boy } & \text { Dãwano } & & & & \end{array}$

7. kuidobo ka enegoaimo

Sago clan woman Enegoai

$b a^{\prime} a \quad k a b u s a$

boy Kabusa 
Songs of the Empty Place

$\begin{array}{lllll}\begin{array}{l}\text { yo } \\ \text { his }\end{array} & \begin{array}{l}\text { hua } \\ \text { mother }\end{array} & \begin{array}{l}\text { wa } \\ \text { woman }\end{array} & \begin{array}{l}\text { mege } \\ \text { only }\end{array} & \begin{array}{l}\text { bamo } \\ \text { this }\end{array} \\ \begin{array}{l}\text { ba'a } \\ \text { boy }\end{array} & \begin{array}{l}\text { dãwano } \\ \text { Dãwano }\end{array} & & \\ \end{array}$

1. Boy, your Yebibu Creek

Let another man eat it

Boy, your Yefua Ridge

Let the bush cover it over

2. Boy, your Yebibu Creek

Let another man eat it

Boy, your Yefua Ridge

Let the bush cover it over

3. Your Sumaniyu Creek

This creek, let another man steal it

This boy's Yahadenabo Creek

Let the bush cover it over

4. Boy, your Agegenebo Creek

Let the forest reclaim it

Boy, your Yebibu Creek

Let the trees cover it up

5. Boy, your Sonobo Ridge

Let the bush cover it

Boy, your Yefua Ridge

The forest will be allowed to hide it

6. The clan of the yerebi bamboo, the man Hamabo

His son, Kabosa

The clan of the yerebi bamboo, this only man

His son, Dãwano

7. The Kuidobo clan woman Enegoai

Her son, Kabosa

His mother, the only woman

Her son, Dãwane 


\section{Men's Song 41}

\section{Singers: Kora and Webirabo. Recorded 16 March 1988 at Hegeso village.}

This song illustrates one of the commonest images used in these songs: a man's inhabited places become reclaimed by the forest after his death, when he is no longer able to maintain them as sites of human intervention. (See Weiner 2001:39-42.)

\begin{tabular}{|c|c|c|}
\hline $\begin{array}{l}b a^{\prime} a \\
\text { boy }\end{array}$ & $\begin{array}{l}n a^{\prime} a \\
\text { your }\end{array}$ & $\begin{array}{l}\text { namikiribibi } \\
\text { Namikiribibi }\end{array}$ \\
\hline $\begin{array}{l}\text { iga } \\
\text { path }\end{array}$ & \multicolumn{2}{|c|}{$\begin{array}{l}\text { aodiba'ae } \\
\text { tree covered }\end{array}$} \\
\hline$b a^{\prime} a$ & $n a^{\prime} a$ & tigifu \\
\hline boy & your & Tigifu \\
\hline $\begin{array}{l}\text { iga } \\
\text { path }\end{array}$ & $\begin{array}{l}\text { aodib } \\
\text { tree }\end{array}$ & \\
\hline
\end{tabular}

$\begin{array}{lll}\text { 2. ba'a } & \text { bamo } & \text { waya'arihabo iburo'o } \\ \text { boy } & \text { this } & \text { Waya'arihabo creek }\end{array}$

aodibihaba'aye

let the bush cover it

$\begin{array}{llll}b a^{\prime} a & \text { bamo } & \text { domege } & i b u \\ \text { boy } & \text { this } & \text { Domege } & \text { creek }\end{array}$

aodoba'aye

let bush cover it

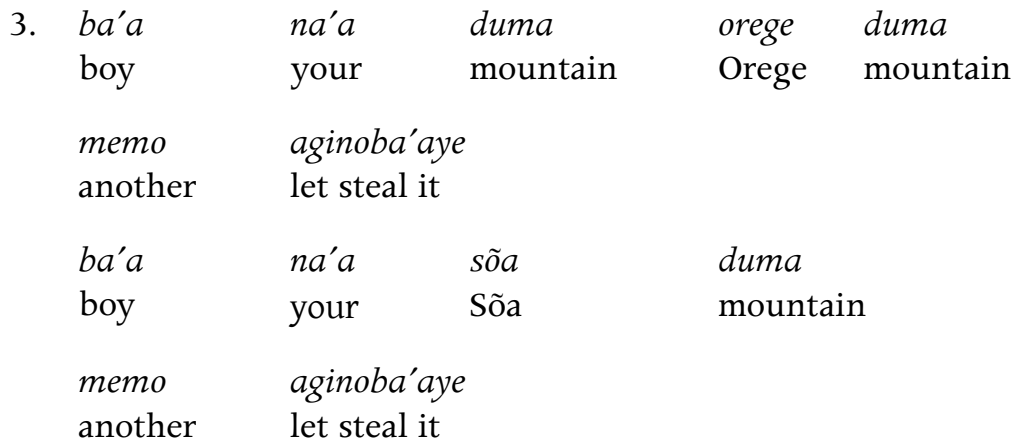




\begin{tabular}{|c|c|c|c|c|c|c|}
\hline 4. & kibudobo & ka & yamo & & & \\
\hline & & & & & & \\
\hline & kabe & sese & & & & \\
\hline & man & Sese & & & & \\
\hline & banimahu'u & & kabe & irahai & bomo & \\
\hline & Banimahu'u & & man & Irahai & & \\
\hline & kabe & sisu'umena & & & & \\
\hline & man & Sisu'umena & & & & \\
\hline 5. & turu & ya & bari & dobo & $b a^{\prime} a$ & irahaimabo \\
\hline & & bird & banima & & & \\
\hline & kabe & sese & & & & \\
\hline & man & Sese & & & & \\
\hline & kibudobo & $k a$ & yamo & & & \\
\hline & Kibudobo & woman & $\mathrm{Ya}$ & & & \\
\hline & kabe & sisu'umena & & & & \\
\hline & man & Sisu'umena & & & & \\
\hline 6. & yo & hua & $k a$ & mege & bamo & \\
\hline & his & mother & woman & only & that & \\
\hline & kabe & sese-o & & & & \\
\hline & man & Sese & & & & \\
\hline & yo & hua & $k a$ & mege & bamo & \\
\hline & his & mother & woman & only & this & \\
\hline
\end{tabular}

1. Boy, your Namikiribi path That path is covered over

Boy, your Tigifu path

That path is hidden by the forest

2. This boy's Waya'arihabo Creek It is obliterated by trees 
This man's Domege Creek

Is covered over by the jungle

3. Boy, your Orege Mountain

Let another man steal it

Boy your Sõa Mountain

Let another man steal it

4. The Kibudobo woman Ya

Her son Sese

The Banimahu'u man Irihaimabo

His son Sisu'umena

5. The clan of the high flying banima bird, Irihaimabo

His son Sese

The Kibudobo woman Ya

Her son Sisu'umena

6. His mother, this woman alone

Her son Sese

His mother, this lonely woman

Ibu Dawabo

\section{Men's Song 42}

\section{Singers: Fahaisabo and Oromene. Recorded 5 January 1985 at Barutage village.}

This song capitalises on the lexical meaning of the deceased's hidden name, Tîbu, which is the name of a variety of cane. The phrase 'cane water' refers to a creek or river alongside which cassowary snares have been set. In common with other Fringe Highlands hunters of this area, the Foi set their traps near known drinking and eating places of animals, and place snares and deadfalls near discovered tracks of animals near the various watercourses and trees in fruit. The elements of haiku are especially noteworthy in the terseness of the phrasing here. $\int$ online example 12.

\begin{tabular}{|c|c|c|c|}
\hline $\begin{array}{l}\text { 1. } b a^{\prime} a \\
\text { boy }\end{array}$ & $\begin{array}{l}n a^{\prime} a \\
\text { your }\end{array}$ & $\begin{array}{l}\text { sui } \\
\text { cane }\end{array}$ & $\begin{array}{l}\text { ko'ome } \\
\text { ko'ome }\end{array}$ \\
\hline
\end{tabular}


Songs of the Empty Place

$\begin{array}{lllll}\begin{array}{l}\text { ibu } \\ \text { water }\end{array} & \begin{array}{l}\text { weigebe } \\ \text { has it come? }\end{array} & & & \\ \begin{array}{l}n a^{\prime} a \\ \text { boy }\end{array} & \text { your } & \begin{array}{l}\text { sui } \\ \text { cane }\end{array} & \begin{array}{l}\text { gagi } \\ \text { gagi }\end{array} & \text { ibu } \\ \begin{array}{l}\text { ibu } \\ \text { water }\end{array} & \text { weiba'ae } & & & \\ \text { has come } & & & \end{array}$

$\begin{array}{llll}\begin{array}{l}\text { 2. } \\ \text { cane }\end{array} & \begin{array}{l}\text { dabe } \\ \text { dabe }\end{array} & \begin{array}{l}\text { ibu } \\ \text { water }\end{array} & \begin{array}{l}\text { wa } \\ \text { come }\end{array} \\ \begin{array}{l}\text { konaye } \\ \text { full }\end{array} & \begin{array}{l}\text { ibae } \\ \text { is }\end{array} & & \\ \text { sui } & \text { gerewa } & \text { ibu } & \text { wa } \\ \text { cane } & \text { gerewa } & \text { water } & \text { come } \\ \text { konaye } & \text { ba'ae } & & \\ \text { full } & \text { is } & & \end{array}$

3. sui

tĩbu ibu

cane tĩbu water

konabo'o dibiga

full stated

sui ko'ome ibu

cane ko'ome water

yiragedobo'o dibiga

coming down from mountain stated

$\begin{array}{lll}\text { 4. sui } & \text { ko'ome } & i b u \\ \text { cane } & \text { ko'ome } & \text { water }\end{array}$

konabo'o dibige

full stated

sui wa ibu

cane come water

konabo'o dibige

full stated

5. orodobo ka wa'ane

Orodobo woman Wa'ane 


$\begin{array}{lll}\text { ba'a } & \begin{array}{l}\text { ayamena } \\ \text { boy }\end{array} & \\ \text { Ayamena } & \\ \text { banimahu'u } & \text { ba'a } & \text { yore } \\ \text { Banimahu'u } & \text { boy } & \text { Yore } \\ \text { kabe } & \text { tĩbu } & \\ \text { man } & \text { Tĩbu } & \end{array}$

\begin{tabular}{|c|c|c|c|}
\hline $\begin{array}{l}\text { 6. karewẽyudobo } \\
\text { Banimahu'u }\end{array}$ & $\begin{array}{l}\text { kabe } \\
\text { man }\end{array}$ & $\begin{array}{l}\text { mege } \\
\text { only }\end{array}$ & $\begin{array}{l}b a \\
\text { that }\end{array}$ \\
\hline
\end{tabular}

\begin{tabular}{|c|c|c|c|c|}
\hline $\begin{array}{l}b a^{\prime} a \\
\text { boy }\end{array}$ & $\begin{array}{l}\text { ayamena } \\
\text { Avamena }\end{array}$ & & & \\
\hline oro & taru & dobo & $k a$ & wa'anemo \\
\hline bamboo & great & clan & woman & Wa'ane \\
\hline$b a^{\prime} a$ & tĩbu & & & \\
\hline boy & Tĩbu & & & \\
\hline
\end{tabular}

1. Boy, your ko'ome cane snare creek Is the water coming?

Boy, your gagi cane snare creek Water is coming

2. Dabe cane snare water coming Water is full

Gerewa cane snare water coming Full

3. Tîbu cane water Full

Ko'ome cane creek

Out of the mouth of the mountain

4. Ko'ome cane creek

Full, we say

Cane coming creek

Full, we say

5. Orodobo woman Wa'ane

The boy Ayamena 
Banimahu'u boy Yore

The man Tĩbu

6. The Karewẽyudobo clan man only

The boy Ayamena

The Great Bamboo clan woman Wa'ane

The boy Tĩbu

\section{Men's Song 43}

\section{Singers: Abeabo and Gobero. Recorded 2 January 1985 at Hegeso village.}

Places in the deep bush, where hunting and fishing activities characteristically take place, are the most common places associated with a man after death, as the imagery in this song depicts.

1. ya

koa

duma

bird

bird of paradise

mountain

aodibihaboba'a

bush covered

$\begin{array}{ll}\begin{array}{ll}\text { yefua } \\ \text { Yefua }\end{array} & \begin{array}{l}\text { duma } \\ \text { mountain }\end{array} \\ \text { ira } & \text { waboba'a } \\ \text { tree } & \text { come }\end{array}$

2. $b a^{\prime} a$

$n a^{\prime} a$

kana

$i b u$

dera

boy

your

stone

creek

that

aodoboba'ae

bush covered

$\begin{array}{llll}b a^{\prime} a & n a^{\prime} a & \text { suanobo } & i b u \\ \text { boy } & \text { your } & \text { fish dammed } & \text { creek }\end{array}$

kigiboba'ae

tree covered

3. yo

$\begin{array}{lll}\text { hua } & k a & \text { fofo } \\ \text { mother } & \text { woman } & \text { Fofo }\end{array}$


$\begin{array}{ll}b a^{\prime} a & \text { kawaru } \\ \text { boy } & \text { Kawaru }\end{array}$

momahu'u ka fofomo

Momahu'u woman Fofo

ba'a baya

boy Baya

4. yo

hua

ka fofo

woman Fofo

ba'a kawaru

boy Kawaru

momahu'u ka fofomo

Momahu'u woman Fofo

$b a^{\prime} a \quad$ baya

boy Baya

1. Bird-of-Paradise mountain

Bush covered

Yefua Mountain

Trees come

2. Boy your stony creek

Bush covered

Boy your fish dammed creek

Strongly covered

3. His mother, Fofo

The boy Kawaru

The Momahu'u clan woman Fofo

The boy Baya

4. His mother, Fofo

The boy Kawaru

The Momahu'u clan woman Fofo

The boy Baya 


\section{Men's Song 44}

\section{Singers: Kora and Webirabo. Recorded 16 March 1988 at Hegeso village.}

As I described in The Empty Place, during a man's life, he leaves imprints or traces on the land, made for example by setting animal traps or constructing fish dams. When a man dies, the bush begins to cover over these traces and erase them, out of which the Foi construe an image of the most common results of a man's death.

1. $b a^{\prime} a$

$n a^{\prime} a$
your

masiba

Masiba

duma

mountain

aodoba'aye

let the bush cover it

$\begin{array}{llll}b a^{\prime} a & n a^{\prime} a & \text { dagina } & i b u \\ \text { boy, } & \text { your } & \text { Dagina } & \text { creek }\end{array}$

kigiba'aye

let the strong trees claim it

2. $b a^{\prime} a$

$n a^{\prime} a$

duma

bugi

duma

boy,

your

mountain

Bugi

mountain

aginoba'aye

let another man steal it

$\begin{array}{llll}b a^{\prime} a & n a^{\prime} a & \text { masiba } & \text { duma } \\ \text { boy, } & \text { your } & \text { Masiba } & \text { mountain }\end{array}$

aginoba'aye

let another man steal it

3. $b a^{\prime} a$

$$
\text { bamo }
$$

dagina

$i b u$

this

boy's

Dagina

creek

aginoba'aye

let another man eat it

$\begin{array}{llll}b a^{\prime} a & \text { bamo } & \text { kubarohimu } & i b u \\ \text { this } & \text { boy's } & \text { Kubarihimu } & \text { creek }\end{array}$

aodoba'aye

let the bush cover it 


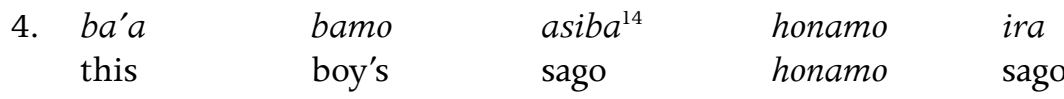

aodoba'aye

let the bush cover it

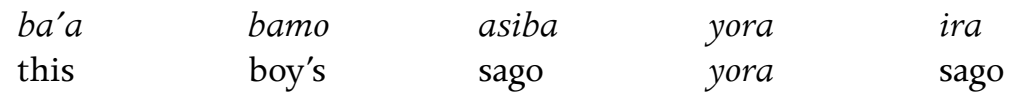

irawaba'ame

let the trees come and cover it

5. wa'aridobo

wa'ari palm clan

kabe

her son,

fumena $^{15}$

ira

the

namanidobo

namani tree clan man,

sega

kabe

his son,

Sega

6. ira

the

namanidobo

namani tree clan

ka

woman,

hasebameno

Hasebame yarogeno

Yaroge yarogemo

kabe

sega

his son,

Sega

yo

hua

$k a$

his

mother,

woman

hasebame

kabe

fumene

the man

Fumene

1. Boy, your Masiba Mountain

Let the bush cover it

Boy, your Dagina Creek

Let the strong trees claim it

14 Asiba or asipa is the Fasu term for 'sago' (May and Loeweke 1981:19).

15 Sega's 'hidden' name. 
2. Boy, your Bugi Mountain Let another man steal it

Boy, your Masiba Mountain

Let another man steal it

3. This boy's Dagina Creek

Let another man eat it

This boy's Kubarihimu Creek

Let the bush cover it

4. This boy's honamo sago

Let the bush cover it

This boy's yora sago

Let the trees come and cover it

5. The wa'ari palm clan woman, Hasebame

Her son, Fumena

The namani tree clan man, Yaroge

His son, Sega

6. The namani tree clan Yaroge

His son, Sega

His mother, the woman Hasebame

The man Fumene 


\section{Women's Songs (Sorohabora)}

\section{Women's Song 1}

\section{Singers: Kunuhuaka and Wa'abiyu. Recorded 4 November 1984 at Hegeso village.}

These songs were performed shortly before the Hegeso men's pig-kill. The first one refers to the dancing that is anticipated after the distribution of the pork. Note that the male singers are likened to birds, a metaphor that is widespread in the ceremonial life throughout the Mt Bosavi-Lake Kutubu area of the Southern Highlands of Papua New Guinea. J J online example 13.

1. wabo medo'ane dobo'owua

wabo bird to sing spoken of

togebe

is this it?

2. bi'a medo'ane dobo'owua

$b i^{\prime} a$ bird to sing spoken of

togebe

is this it?

3. ya

koa

ũbo so'ane

dobo'owua

bird

Raggianna

headdress

to hang down

spoken of

togebe

is this it?

4. for

hornbill sings

ya

bird

sore

medo'ane

dobo'owua

togebe

is this it?

5. hubage $\tilde{u}$

feathers head

\section{ho'ane}

dobo'owua

togebe

is this it? 
6urubu gugu'anege dobo'owua
furubu to flower spoken of

togebe

is this it?

7. ya

$\begin{array}{llll}\text { ya } & b i^{\prime} a & \text { medo'ane } & \text { dobo'owua } \\ \text { bird } & b i^{\prime} a & \text { to sing } & \text { spoken of }\end{array}$

togebe

is this it?

8. $\begin{array}{lll}\text { ya } & \text { sore } & \text { medo'ane } \\ \text { bird } & \text { sore } & \text { dobo'owua } \\ \text { to sing } & \text { spoken of }\end{array}$
togebe
is this it?

9. amena yagenebo u'ubi

men Yagenebo children

dawa-o

dawabo

10. kaibutage u'ubi

Kaibutage children

dawa-o

dawabo

11. baiga

$\begin{array}{ll}\text { sabe } & u^{\prime} u b i \\ \text { Ridge } & \text { children }\end{array}$

dawa-o

dawabo

1. The wabo bird that we have been speaking of for so long Is this it?

2. The $b i^{\prime} a$ bird we have been speaking of Is this bird singing now?

3. The bird-of-paradise feathers that hang down Is it these here? 
4. The hornbill and sore bird Is it they who are singing now?

5. The Chimbu men's black head feathers

Are these hanging from men's heads?

6. They have been saying that the furubu tree will carry many flowers Is it now going to happen?

7. The $b i^{\prime} a$ bird we have been speaking of Is this bird singing now?

8. The sore bird that has been singing Is it this one singing now?

9. The children of Yagenebo Dawa

10. The children of the mouth of the Kaibu River Dawa

11. The children of Baiga Ridge Dawa

\section{Women's Song 2}

\section{Singers: Kunuhuaka and Wa'abiyu. Recorded 4 November 1984 at Hegeso village.}

Kunuhuaka's eldest son, Bebe, joined the Papua New Guinea Defence Force and eventually was stationed in Manus Island. This song, one of many that Kunuhuaka composed for her son, describes his departure. Traditionally, enemies were referred to as 'wasps' and as hawks and other birds of prey. (Figure 6 in this volume is a music transcription of lines 8-11.) J online example 14.

$\begin{array}{llll}\text { 1.ngi } & \text { burusumaremo } & \text { ari } & \text { viba'ae } \\ \text { wasp } & \text { burusama } & \text { house } & \text { gone } \\ \text { bi } & \text { sinae } & & \\ \text { here } & \text { abandoned } & & \end{array}$




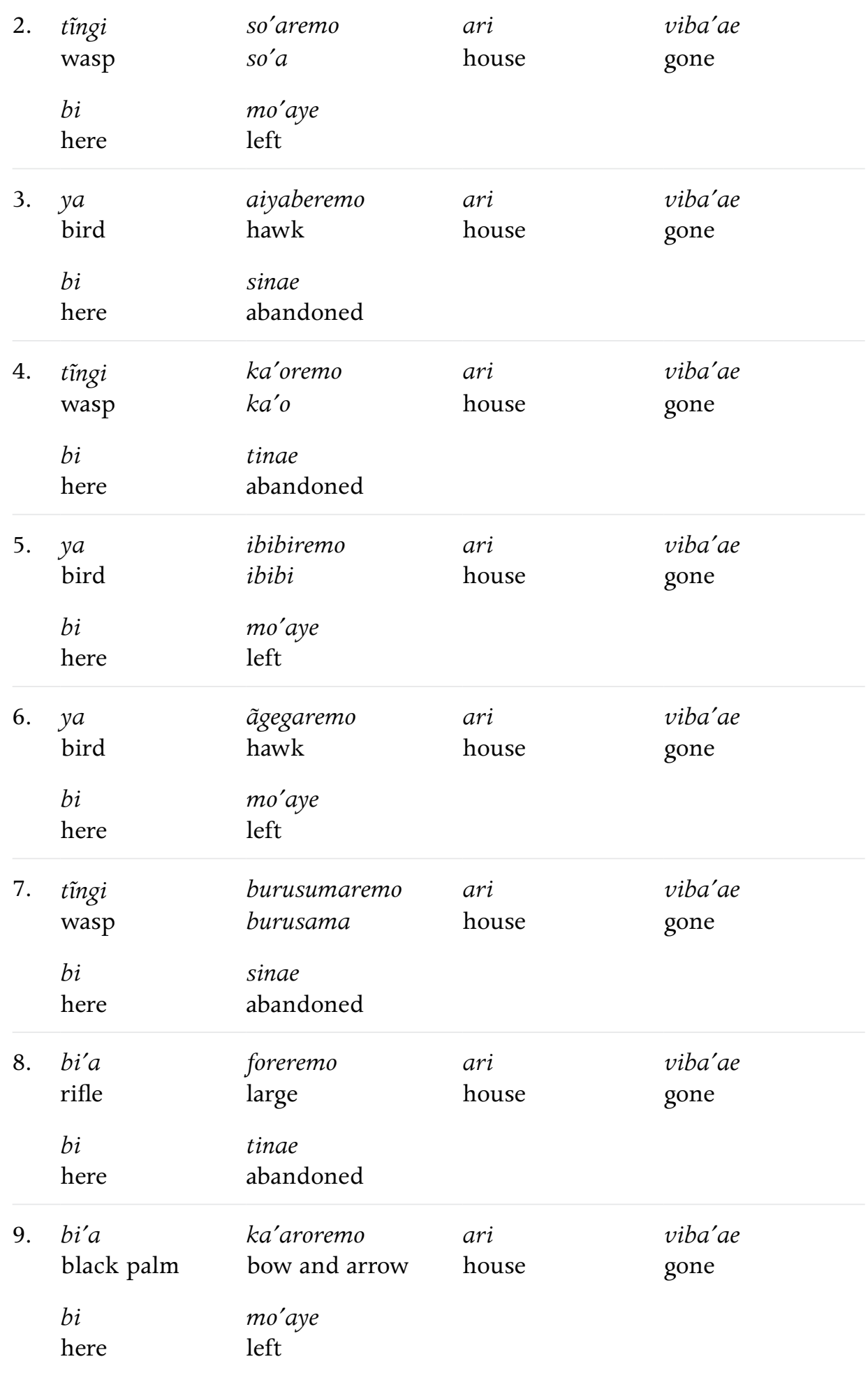




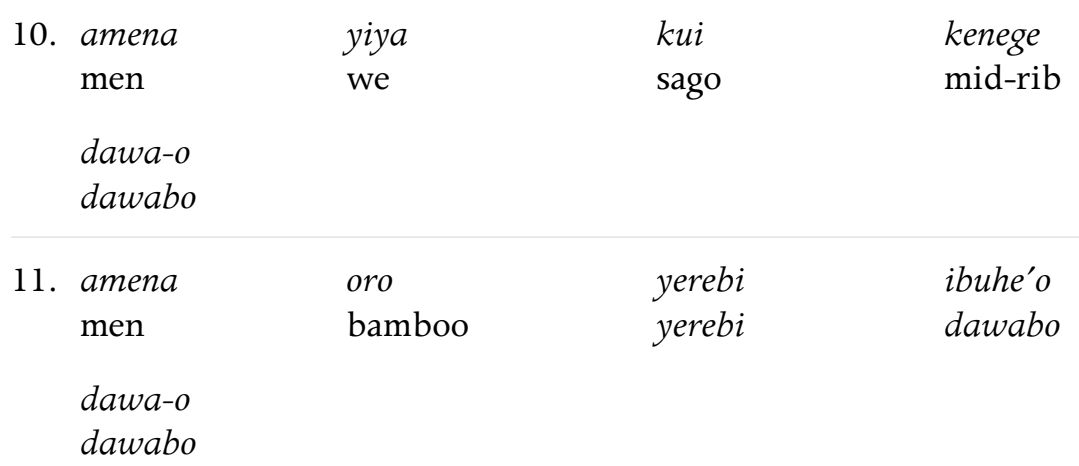

1. Into the house of the burusama wasps you have gone Abandoning this place

2. Into the house of the wasps larvae you have gone Leaving here

3. Into the hawk's house you have entered Departing

4. Into the $k a^{\prime} o$ wasps house you have gone Abandoning this place

5. Into the house of the ibibi hawk you have entered Left here

6. Into the house of the ãgega hawk You have abandoned this place

7. Into the house of the burusama wasps you have gone Abandoning this place

8. Into the house of the big rifle You have left here

9. Into the house of the metal bow and arrow You have gone, leaving this place

10. We are the men of the Sago Bark clan Dawa

11. We are the men of the yerebi bamboo clan Ibu he'o dawa 


\section{Women's Song 3}

\section{Singers: Kunuhuaka and Wa'abiyu. Recorded 4 November 1984 at Hegeso village.}

This song describes the aeroplane that took Kunuhuaka's son Bebe away from Hegeso and to his posting with the Papua New Guinea Defence Force. The Foi term bare, which means 'canoe', became used for any motorised vehicle they came to know, most commonly the aeroplane, and in this song, Kunuhuaka comments on the relationship between canoe and aeroplane. J online example 15.

1. bare yuramaboba'ae

canoe pull + take

bi mo'aye

here left

2. bare arurudiba'ae

canoe crooked

bi tinae

here abandoned

3. duma hunabu orori huboba'ae

mountain Hunabu peak pierced

bi tinae

here abandoned

4. duma dagerabo orori huboba'ae

mountain Dagerabo peak pierced

bi mo'aye

here left

5. $i b u$

suki

fufaboba'ae

river

Suki

fly away

bi sinae

here abandoned

6. duma hua uboba'ae

mountain cloud pierced has gone

bi sinae

here abandoned 


\begin{tabular}{|c|c|c|c|c|c|}
\hline 7. & $\begin{array}{l}\text { duma } \\
\text { mountain }\end{array}$ & $\begin{array}{l}\text { buru } \\
\text { black }\end{array}$ & $\begin{array}{l}\text { orori } \\
\text { peak }\end{array}$ & $\begin{array}{l}\text { huboba'ae } \\
\text { pierced }\end{array}$ & \\
\hline & $\begin{array}{l}b i \\
\text { here }\end{array}$ & $\begin{array}{l}\text { mo'aye } \\
\text { left }\end{array}$ & & & \\
\hline 8. & $\begin{array}{l}\text { bare } \\
\text { canoe }\end{array}$ & $\begin{array}{l}\text { arurudiba'ae } \\
\text { crooked }\end{array}$ & & & \\
\hline & $\begin{array}{l}b i \\
\text { here }\end{array}$ & $\begin{array}{l}\text { tinae } \\
\text { abandoned }\end{array}$ & & & \\
\hline 9. & $\begin{array}{l}\text { bare } \\
\text { canoe }\end{array}$ & $\begin{array}{l}\text { yura } \\
\text { pulled }\end{array}$ & $\begin{array}{l}\text { uboba'ae } \\
\text { has gone }\end{array}$ & & \\
\hline & $\begin{array}{l}b i \\
\text { here }\end{array}$ & $\begin{array}{l}\text { sinae } \\
\text { abandoned }\end{array}$ & & & \\
\hline 10. & $\begin{array}{l}k u i \\
\text { sago }\end{array}$ & $\begin{array}{l}\text { kenege } \\
\text { mid-rib }\end{array}$ & $\begin{array}{l}\text { dobo } \\
\text { clan }\end{array}$ & $\begin{array}{l}k a \\
\text { woman }\end{array}$ & $\begin{array}{l}\text { bamo } \\
\text { that }\end{array}$ \\
\hline & $\begin{array}{l}b a^{\prime} a \\
\text { boy }\end{array}$ & $\begin{array}{l}\text { terewaro } \\
\text { Terewaro }\end{array}$ & & & \\
\hline 11. & $\begin{array}{l}\text { oro } \\
\text { bamboo }\end{array}$ & $\begin{array}{l}\text { yerebi } \\
\text { yerebi }\end{array}$ & $\begin{array}{l}\text { dobo } \\
\text { clan }\end{array}$ & $\begin{array}{l}b a^{\prime} a \\
\text { boy }\end{array}$ & $\begin{array}{l}\text { bamo } \\
\text { that }\end{array}$ \\
\hline
\end{tabular}

1. The aeroplane pulled him inside He has left this place

2. The aeroplane, as crooked as a canoe It left this place

3. It crossed the top of Mt Hunabu Leaving this place

4. Over the crest of Mt Dagerabo It abandoned this place

5. It flew away to the land of the Wage River Abandoning this place 
6. Through the cloud covered mountains it went Leaving here

7. Over the top of the dark blue mountain It left this place behind

8. The aeroplane, as crooked as a canoe It left this place

9. It pulled him inside and left Abandoning this place

10. The woman of the Sago Bark clan Her son, Terewaro

11. The yerebi bamboo clan boy Dawabo

\section{Women's Song 4}

\section{Singers: Kunuhuaka and Wa'abiyu. Recorded 4 November 1984 at Hegeso village.}

This song appeared in The Empty Place (Weiner 1991:144-46). It describes the indignation a woman feels when confronted with her husband's suspicions that she is trying to seduce another man. J online example 16.

$\begin{array}{llll}\begin{array}{l}\text { 1. } \\ \text { eye }\end{array} & \begin{array}{l}\text { huni } \\ \text { beckons }\end{array} & \begin{array}{l}\text { mabo } \\ \text { steals }\end{array} & \begin{array}{l}\text { kabore } \\ \text { girl }\end{array} \\ \text { I } & \begin{array}{l}\text { wae } \\ \text { not }\end{array} & & \\ \text { 2. ya } & \text { huni } & \text { mabo } & \text { kabore } \\ \text { hand } & \text { beckons } & \text { steals } & \text { girl } \\ \text { na } & \text { wae } & & \\ \text { I } & \text { not } & & \end{array}$




\begin{tabular}{|c|c|}
\hline $\begin{array}{l}\text { 3. fufuruforabo } \\
\text { wander }\end{array}$ & $\begin{array}{l}\text { kabori } \\
\text { girl }\end{array}$ \\
\hline$n a$ & iyo'oyebe \\
\hline I & is not me \\
\hline
\end{tabular}

4. iri

tree

irikaro

twigs

gõ

hagibu kabore

string bag carrying girl

na wae

I

not

5. amena

men

oro

bamboo

yerebi

dobo

dawa-o

dawabo

6.

$\begin{array}{llll}\begin{array}{l}\text { amena } \\ \text { men }\end{array} & \text { ira } & \text { ma'aru } & \text { dobo } \\ \text { tree } & \text { clan }\end{array}$

1. The kind of girl who looks around furtively

I'm not that type

2. The kind of girl who beckons towards men with her hand That's not me

3. The kind of girl that wanders around searching for men I'm not that kind

4. The kind of girl who throws twigs at men's feet That's not me

5. The men of the yerebi bamboo clan Dawa

6. The men of the ma'arua tree clan Dawa 


\section{Women's Song 5}

\section{Singers: Kunuhuaka and Wa'abiyu. Recorded 4 November 1984 at Hegeso village.}

A woman complains about her maltreatment by her husband: 'You beat me because I don't do all these tasks, but you have never told me to do them,' she sings. J online example 17.

\begin{tabular}{|c|c|c|c|c|c|}
\hline 1. & $\begin{array}{l}u^{\prime} u b i \\
\text { child }\end{array}$ & $\begin{array}{l}\text { kama } \\
\text { female }\end{array}$ & $\begin{array}{l}\text { ere } \\
\text { mind }\end{array}$ & $\begin{array}{l}\text { dibure } \\
\text { said }\end{array}$ & \\
\hline & nena & doma'ae & & & \\
\hline & no reason & say & & & \\
\hline 2. & wãsia & neri & hirima & diburo & \\
\hline & pitpit & neri & plant & talk & \\
\hline & nena & dee & & & \\
\hline & nothing & say & & & \\
\hline 3. & wãsia & kamua & hirima & diburo & \\
\hline & pitpit & kamua & plant & talk & \\
\hline & nena & dee & & & \\
\hline & nothing & say & & & \\
\hline 4. & nami & buru & kirari & $m a$ & dibure \\
\hline & pig & black & rope & take & said \\
\hline & nena & dee & & & \\
\hline & nothing & say & & & \\
\hline 5. & busu & $u^{\prime} u b i$ & ere & dibure & \\
\hline & kin & children & mind & said & \\
\hline & nena & do'abobi & & & \\
\hline & no reason & should say & & & \\
\hline 6. & ira & $d o^{\prime} a$ & $g a$ & ke & di'ame \\
\hline & tree & $d o^{\prime} a$ & base & burn & said perhaps \\
\hline & nena & dee & & & \\
\hline & no reason & say & & & \\
\hline
\end{tabular}




\begin{tabular}{|c|c|c|c|c|c|}
\hline \multirow[t]{3}{*}{7.} & $\begin{array}{l}\text { kui } \\
\text { sago }\end{array}$ & $\begin{array}{l}h u \\
\text { pound }\end{array}$ & $\begin{array}{l}\text { tirarude } \\
\text { pith shredded }\end{array}$ & $\begin{array}{l}\text { ma } \\
\text { take }\end{array}$ & $\begin{array}{l}\text { diburo } \\
\text { talk }\end{array}$ \\
\hline & nena & dee & & & \\
\hline & no reason & say & & & \\
\hline 8. & $\begin{array}{l}\text { kare } \\
\text { women's }\end{array}$ & $\begin{array}{l}k u i \\
\text { sago }\end{array}$ & $\begin{array}{l}\text { ini } \\
\text { cook }\end{array}$ & $\begin{array}{l}\text { diburo } \\
\text { talk }\end{array}$ & \\
\hline & nena & dee & & & \\
\hline & nothing & say & & & \\
\hline 9. & $\begin{array}{l}\text { amena } \\
\text { men }\end{array}$ & $\begin{array}{l}\text { oro } \\
\text { bamboo }\end{array}$ & $\begin{array}{l}\text { yerebi } \\
\text { yerebi }\end{array}$ & & \\
\hline & $\begin{array}{l}\text { dawa-o } \\
\text { dawabo }\end{array}$ & & & & \\
\hline 10. & $\begin{array}{l}\text { amena } \\
\text { men }\end{array}$ & $\begin{array}{l}\text { ira } \\
\text { tree }\end{array}$ & $\begin{array}{l}m a^{\prime} a r u \\
m a^{\prime} a r u\end{array}$ & & \\
\hline
\end{tabular}

1. Look after our little girl, you say You tell me nothing

2. You want me to plant neri pitpit But you have said nothing to me

3. You want me to plant kamua pitpit But not a word have you said to me

4. Take the black pig rope, you say But did you say anything to me

5. Look after your maternal clan's children But shouldn't you tell me first

6. Burn down the $d o^{\prime} a$ trees and make a garden But you have told me nothing

7. Prepare sago for washing I heard you say nothing 
8. Cook mid-day sago, you want

But I have heard nothing

9. The men of the yerebi bamboo clan

Dawa

10. The men of the $m a^{\prime}$ aru tree clan

Dawa

\section{Women's Song 6}

\section{Singers: Yiakahua and Ama'a. Recorded 4 November 1984 at Hegeso village.}

I discussed this song in The Empty Place (Weiner 1991:25). The subject is the hand of a man who planted vegetable crops in his garden, which has been stilled by death.

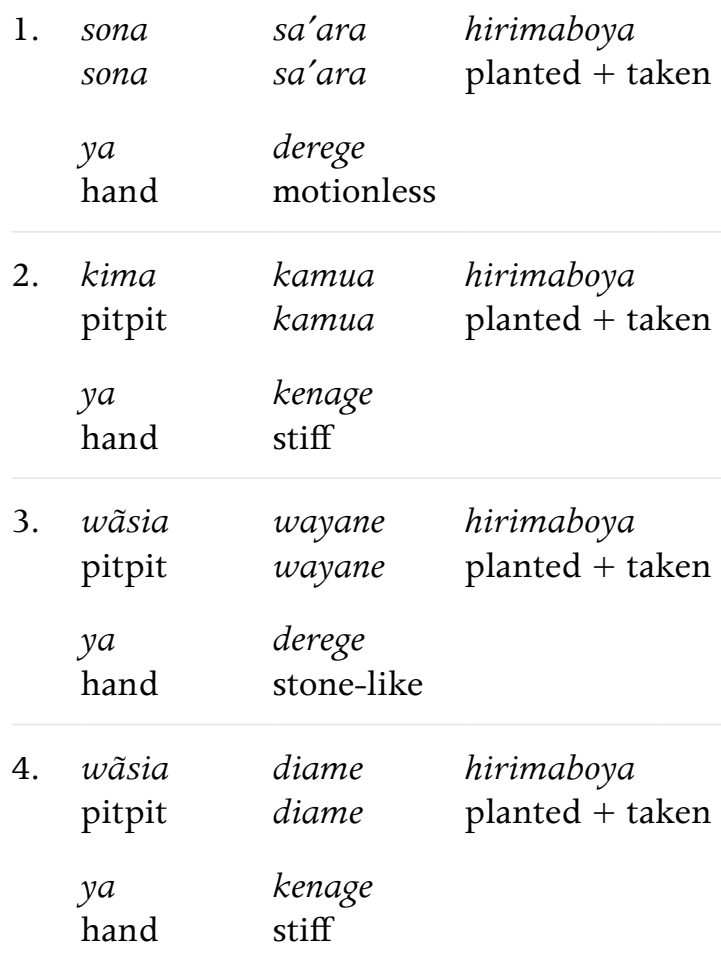




\begin{tabular}{|c|c|c|c|c|c|}
\hline 5. & $\begin{array}{l}\text { ira } \\
\text { tree } \\
\text { dawabo } \\
\text { dawabo }\end{array}$ & $\begin{array}{l}\text { namani } \\
\text { namani }\end{array}$ & $\begin{array}{l}\text { dobo } \\
\text { clan }\end{array}$ & $\begin{array}{l}\text { yaroge } \\
\text { Yaroge }\end{array}$ & $\begin{array}{l}\text { ma'ame } \\
\text { thing }\end{array}$ \\
\hline 6. & $\begin{array}{l}\text { wa'ari } \\
\text { palm } \\
\text { dawabo } \\
\text { dawabo }\end{array}$ & $\begin{array}{l}\text { dobo } \\
\text { clan }\end{array}$ & $\begin{array}{l}\text { hasobe } \\
\text { Hasobe }\end{array}$ & $\begin{array}{l}\text { ma'ame } \\
\text { thing }\end{array}$ & \\
\hline 7. & $\begin{array}{l}\text { ira } \\
\text { tree } \\
\text { dawabo } \\
\text { dawabo }\end{array}$ & $\begin{array}{l}\text { namani } \\
\text { namani }\end{array}$ & $\begin{array}{l}\text { dobo } \\
\text { clan }\end{array}$ & $\begin{array}{l}\text { ma'ame } \\
\text { thing }\end{array}$ & \\
\hline 8. & $\begin{array}{l}\text { wa'ari } \\
\text { palm } \\
b a^{\prime} a \\
\text { boy }\end{array}$ & $\begin{array}{l}\text { dobo } \\
\text { clan } \\
\text { sega } \\
\text { Sega }\end{array}$ & $\begin{array}{l}\text { ka } \\
\text { woman }\end{array}$ & $\begin{array}{l}\text { mege } \\
\text { only }\end{array}$ & $\begin{array}{l}b a \\
\text { that }\end{array}$ \\
\hline
\end{tabular}

1. He who planted the sa'ara sona His hand is cold

2. He who planted the kamua pitpit His hand is stiff and lifeless

3. He who planted the wayane pitpit His hand is dead

4. He who planted the diame pitpit His hand is still and without life

5. He of the clan of the namani tree, Yaroge Dawa

6. She of the clan of the wa'ari tree, Hasobe Dawa 
7. The man of the namani tree clan Yaroge

8. The child of the $w a^{\prime}$ ari tree woman only The boy Sega

\section{Women's Song 7}

\section{Singers: Yiakahua and Ama'a. Recorded 4 November 1984 at Hegeso village.}

In this song, the women make an equation between the covering over of a man's traces on his land and its reappropriation by another man, which among the Foi is usually a man from the same clan. This process of internal succession to a deceased man's habitual territory is a normative and collectively sanctioned process; nevertheless, in the context of this mourning song, in light of the feelings of loss caused by a death, it may be construed as theft of land by the deceased's relatives. J online example 18.

\begin{tabular}{|c|c|c|c|c|}
\hline 1. & $\begin{array}{l}b a^{\prime} a \\
\text { boy } \\
\text { memo } \\
\text { another }\end{array}$ & $\begin{array}{l}n a^{\prime} a \\
\text { your } \\
g a^{\prime} a e \\
\text { possesses }\end{array}$ & $\begin{array}{l}\text { kone } \\
\text { white } \\
\end{array}$ & $\begin{array}{l}i b u \\
\text { creek }\end{array}$ \\
\hline 2. & $\begin{array}{l}b a^{\prime} a \\
\text { boy } \\
\text { memo } \\
\text { another }\end{array}$ & $\begin{array}{l}n a^{\prime} a \\
\text { your } \\
g a^{\prime} a e \\
\text { possesses }\end{array}$ & $\begin{array}{l}\text { da'arefai } \\
\text { Da'arefai } \\
\end{array}$ & $\begin{array}{l}i b u \\
\text { creek }\end{array}$ \\
\hline 3. & $\begin{array}{l}b a^{\prime} a \\
\text { boy } \\
\text { aodoba } \\
\text { let bus. }\end{array}$ & $\begin{array}{l}n a^{\prime} a \\
\text { your }\end{array}$ & $\begin{array}{l}\text { suanobo } \\
\text { fish dammed }\end{array}$ & $\begin{array}{l}i b u \\
\text { creek }\end{array}$ \\
\hline
\end{tabular}




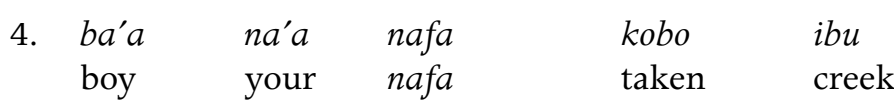

kigiba'ae

bush covered

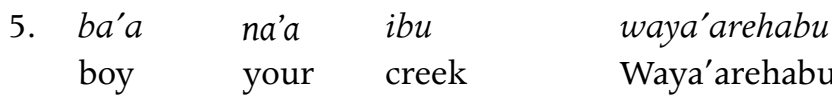

ibu aodoba'aye

creek let bush cover it

6. $b a^{\prime} a$ na'a dabahabo ibu

boy your Dabahabo creek

memo ga'ae

another possesses

7. $b a^{\prime} a$ na'a baruagahabo ibu

boy your Baruagahabo creek

aodoba'aye

let bush cover it

8. $b a^{\prime} a$ na'a orege duma

boy your Orege mountain

memo ga'ae

another possesses

9. $b a^{\prime} a$ na'a domege ibu

boy your Domege creek

aodoba'aye

let bush cover it

10. ba'a na'a igiri ga ibu

boy your Igiri source creek

memo ga'ae

another possesses

11. $b a^{\prime} a$ na'a munusuhabo ibu

boy your Munusuhabo creek

kigiba'aye

let strong bush 
Songs of the Empty Place

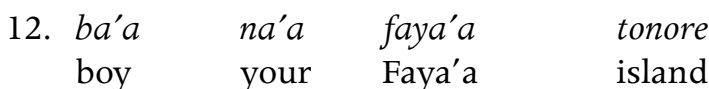

memo ga'ae

another possesses

13. $b a^{\prime} a$ na'a so'a duma

boy your So'a mountain

aginoboba'ae

let another steal it

14. ba'a na'a yegi kobo ibu

boy your fish taken creek

kigiba'ae

bush covered

15. ba'a na'a ira

boy your tree

sabe hũga

gamage aginoboba'ae

later let another steal it

16. $b a^{\prime a} n a^{\prime a}$ gibi moge

boy your bush fowl eggs

aodoboba'ae

bush covered

17. $b a^{\prime} a$ na'a buduru hũga

boy your buduru larvae

viraba'aye

let them fly away

18. orohuĩ ibu

Orohuĩ creek

aodoboba'ae

bush covered 


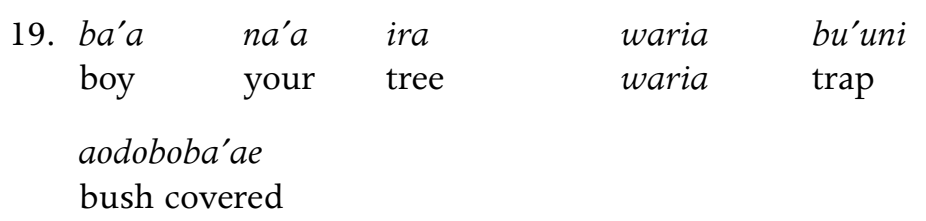
20. oro masiba ira
bamboo masiba tree
ira waboba'ae
tree let them come

21. ba'a na'a metega kui

boy your hidden sago

aginoba'aye

let another steal it

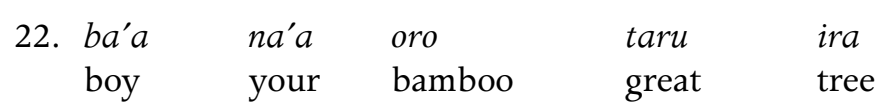

aodoboba'ae

bush covered

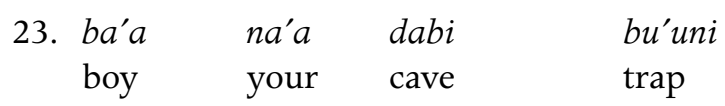

kigiboba'ae

tree covered

24. $b a^{\prime} a$ na'a ibu suanibibi

boy your creek dammed-eaten

kigiboba'ae

tree covered

25. ba'a na'a aiyebo'ao ibu

boy your Aiyebo'ao creek

ira waba'ane

tree let them come

26. amena oro yerebi

men bamboo yerebi

$b a^{\prime} a \quad$ terewaro

boy Terewaro 


\begin{tabular}{|c|c|c|c|c|c|c|c|}
\hline 27. & $\begin{array}{l}\text { kane } \\
\text { vine } \\
n a^{\prime} a b o \\
\text { to you }\end{array}$ & $\begin{array}{l}\text { baniyu } \\
\text { baniyu } \\
\text { dibige } \\
\text { stated }\end{array}$ & $\begin{array}{l}k a \\
\text { woman }\end{array}$ & $\begin{array}{l}\text { mege } \\
\text { only }\end{array}$ & $\begin{array}{l}b a \\
\text { that }\end{array}$ & $\begin{array}{l}\text { ma'ame } \\
\text { thing }\end{array}$ & \\
\hline 28. & $\begin{array}{l}k u i \\
\text { sago } \\
b a^{\prime} a \\
\text { boy }\end{array}$ & $\begin{array}{l}\text { kenege } \\
\text { mid-rib } \\
\text { bebe } \\
\text { Bebe }\end{array}$ & $\begin{array}{l}\text { dobo } \\
\text { clan }\end{array}$ & $\begin{array}{l}k a \\
\text { woman }\end{array}$ & $\begin{array}{l}b a \\
\text { that }\end{array}$ & $\begin{array}{l}\text { ma'ame } \\
\text { thing }\end{array}$ & \\
\hline 29. & $\begin{array}{l}\text { ira } \\
\text { tree } \\
n a^{\prime} a b o \\
\text { to you }\end{array}$ & $\begin{array}{l}\text { yaro } \\
\text { ma'aru } \\
\text { dibige } \\
\text { stated }\end{array}$ & $\begin{array}{l}\text { dobo } \\
\text { clan }\end{array}$ & $\begin{array}{l}k a \\
\text { woman }\end{array}$ & $\begin{array}{l}\text { mege } \\
\text { only }\end{array}$ & $\begin{array}{l}b a \\
\text { that }\end{array}$ & $\begin{array}{l}\text { ma'ame } \\
\text { thing }\end{array}$ \\
\hline
\end{tabular}

1. Boy, your swift white water Is another man's now

2. Boy, your Da'arefai Creek Belongs to another

3. Boy, your fish dammed creek Another has taken it

4. Boy, your creek of the nafa fish Has been covered with bush

5. Boy, your Waya'arehabu Creek The bush has hidden that creek

6. Boy, your Dabahabo Creek It is another's now

7. Boy, your Baruagahabo Creek Covered with jungle

8. Boy, your Mt Orege

It is another's

9. Boy, your Domege Creek

Bush reclaimed 
10. Boy, your Igiri Creek

It is someone else's now

11. Boy, your Munusuhabo Creek

Let the jungle claim it

12. Boy, your Hegeso longhouse

It is another's

13. Boy, your Mt So'a

Stolen

14. Boy, your fish creeks

Bush covered

15. Boy, your sabe tree grubs

Another man will eat them

16. Boy, your bush fowl eggs

Hidden by the bush

17. Boy, your buduru tree grubs

Turned into butterflies

18. Orohuĩ Creek

Bush covered

19. Your waria fruit traps

Jungle hidden

20. Your masiba bamboo

Tree hidden

21. Your secret sago palms

Now another will eat them

22. Your taru bamboo

Later will be eaten

23. Your cave deadfalls

Bush covered

24. Your fish dam creeks

Jungle taken 
25. Your Aiyebo'ao Creek

Let the trees come

26. The man of the yerebi bamboo clan

Boy Terewaro

27. The woman of the baniyu fruit

It is I who speak to you

28. The woman of the Sago Bark clan

The Boy Bebe

29. The $m a^{\prime} a r u$ tree clan woman

I your mother am speaking to you 


\section{Photographs}

Photographs have been chosen to represent some of the images evoked in the song texts, to portray some of the singers who sang the songs transcribed here, and to show some features of the performance context. All photographs are by James Weiner, unless noted otherwise.

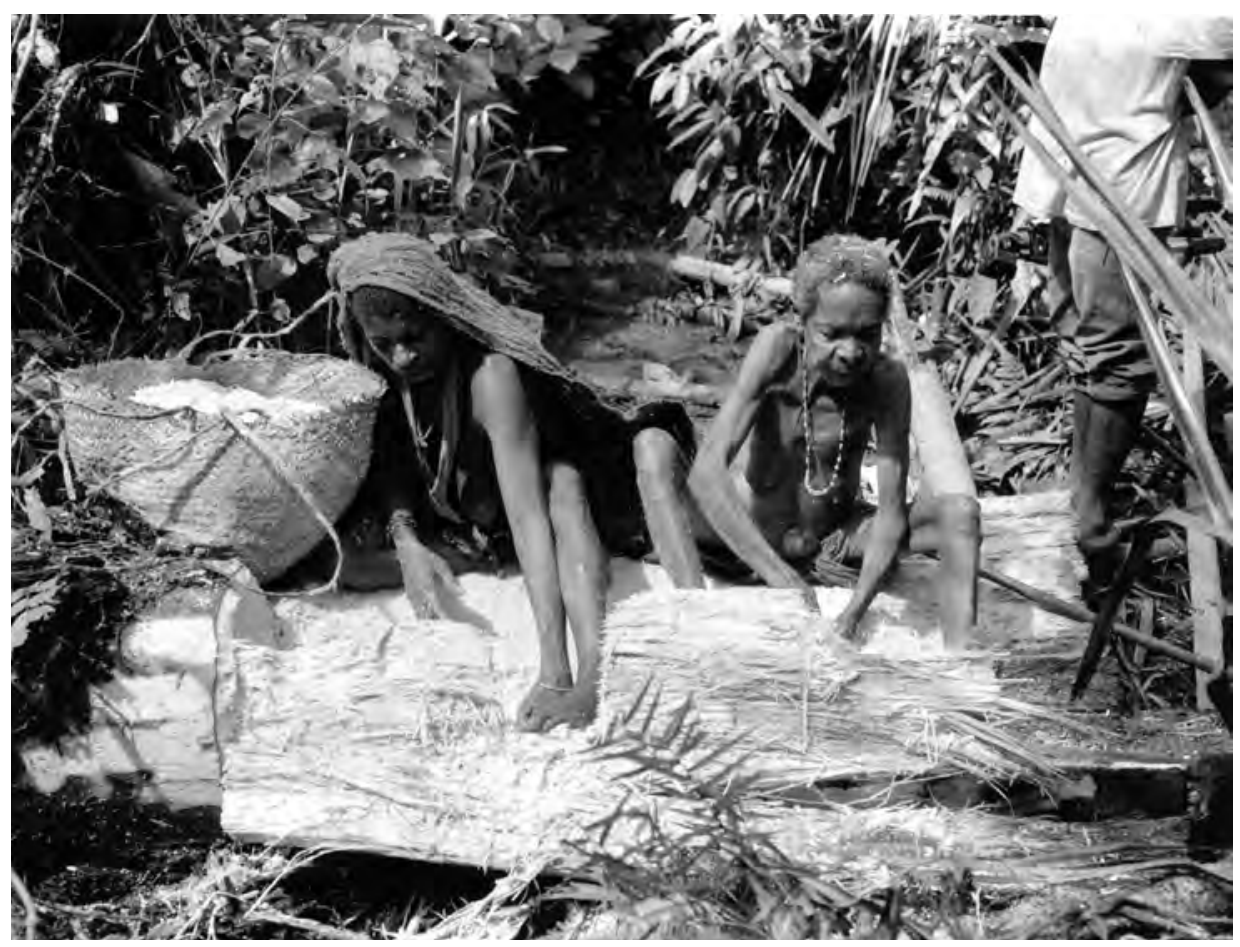

Photo 1: Dafimi (Barutage) and her mother making sago, Hegeso village, c. 1980 . 


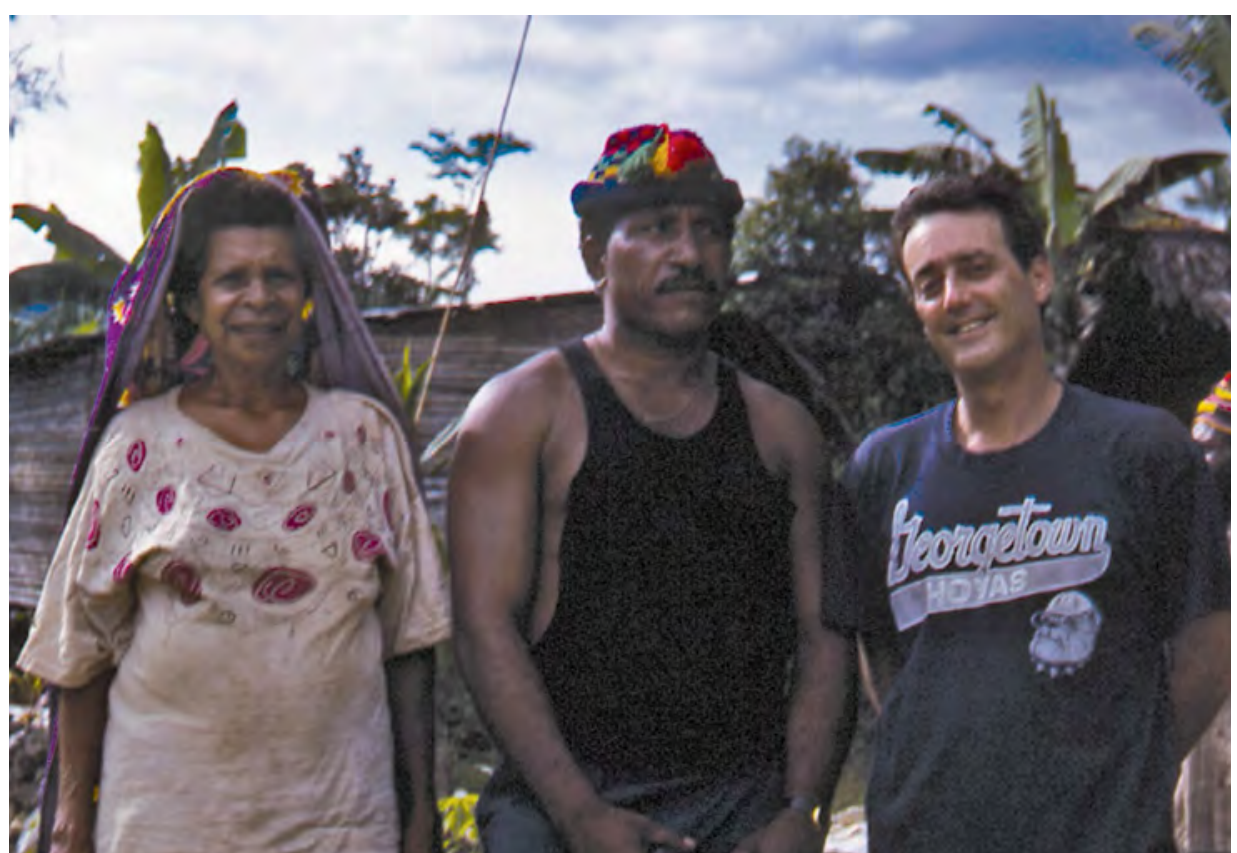

Photo 2: Kunuhuaka, her son Bebe, and James Weiner, at Hegeso, 1980.

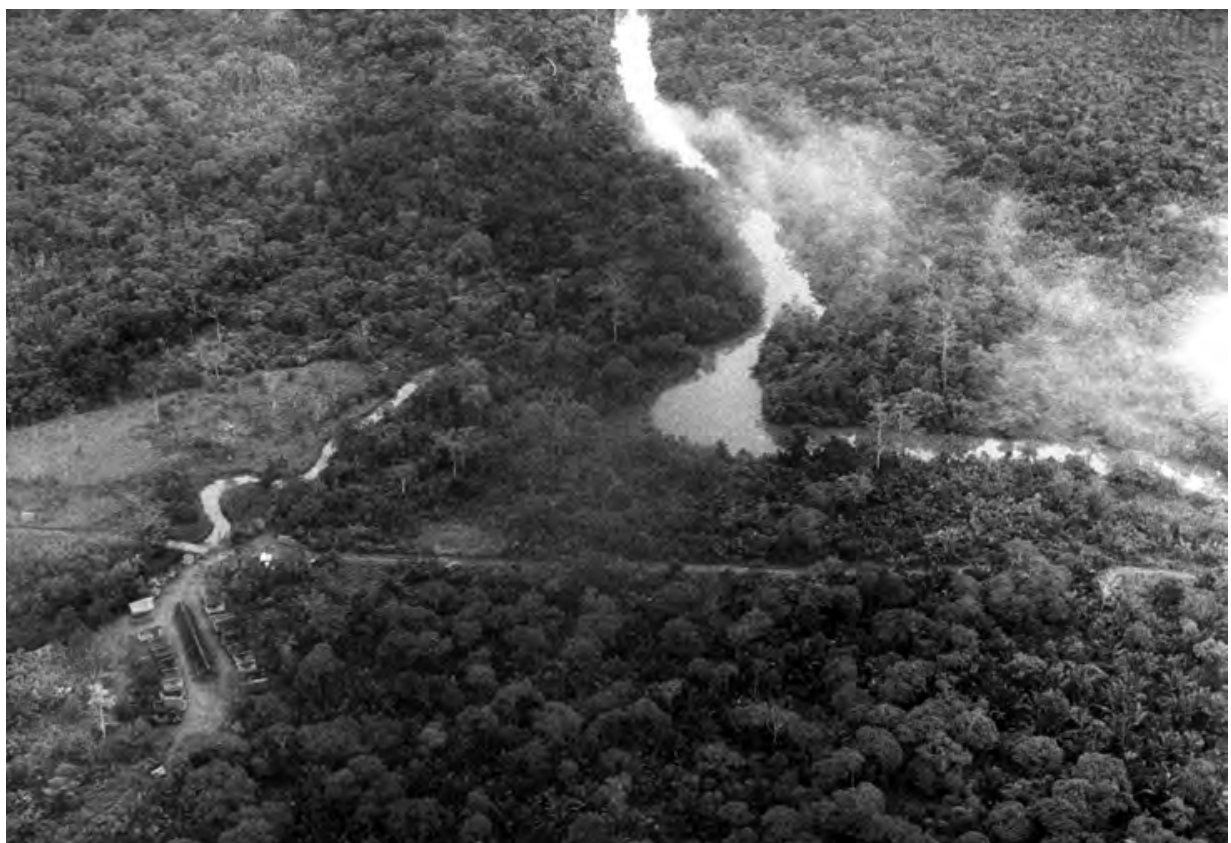

Photo 3: Hegeso longhouse, near junction of Faya'a Creek and Mubi River, c. 1980 . 


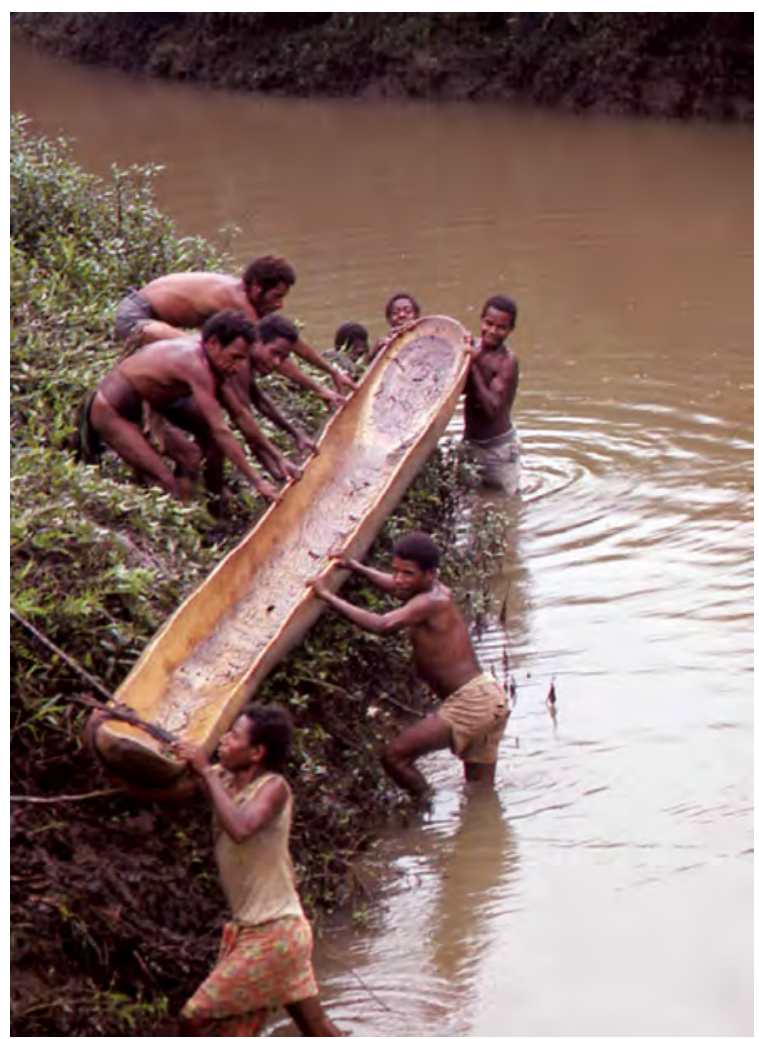

Photo 4: Launching a new canoe in Faya'a Creek, Hegeso village, c. 1980.

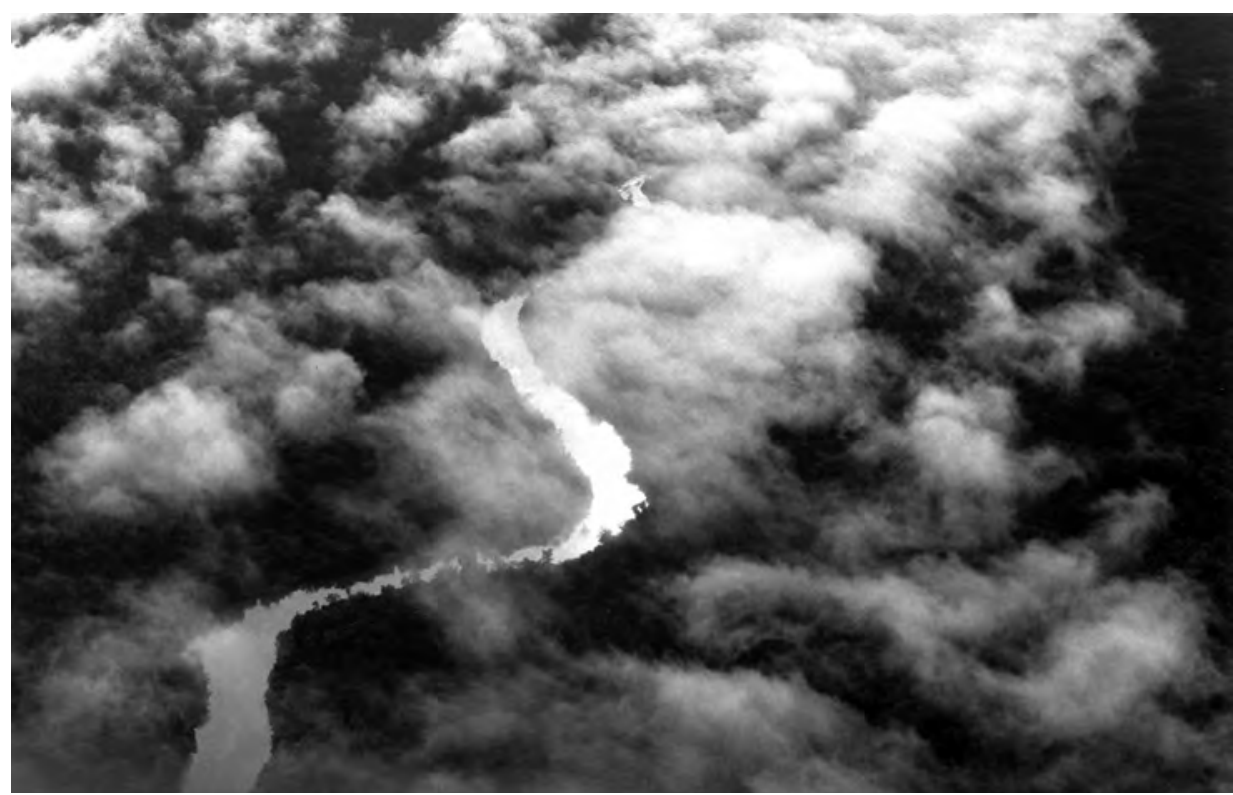

Photo 5: View of Mubi River from low-flying aeroplane, c. 1980. 


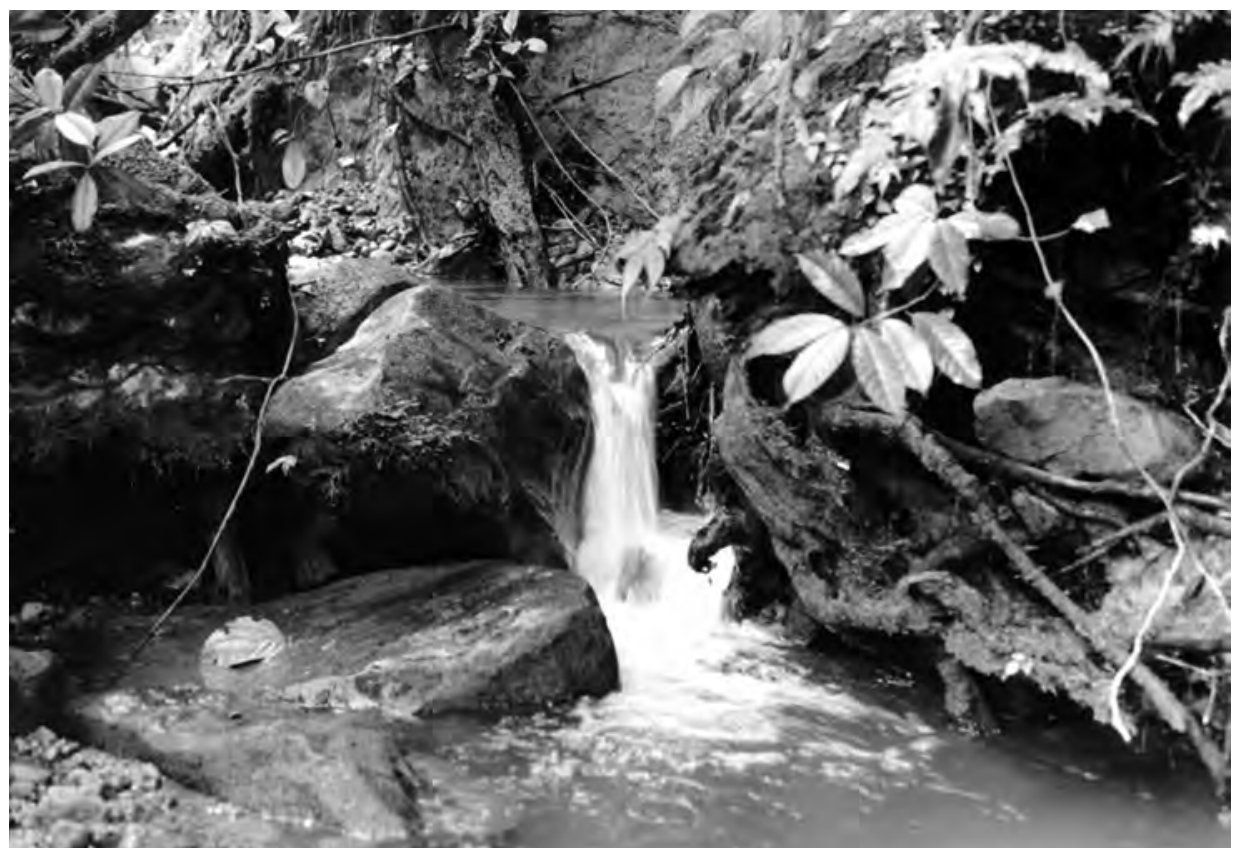

Photo 6: One of many small waterfalls along the creeks in the vicinity of Hegeso village.

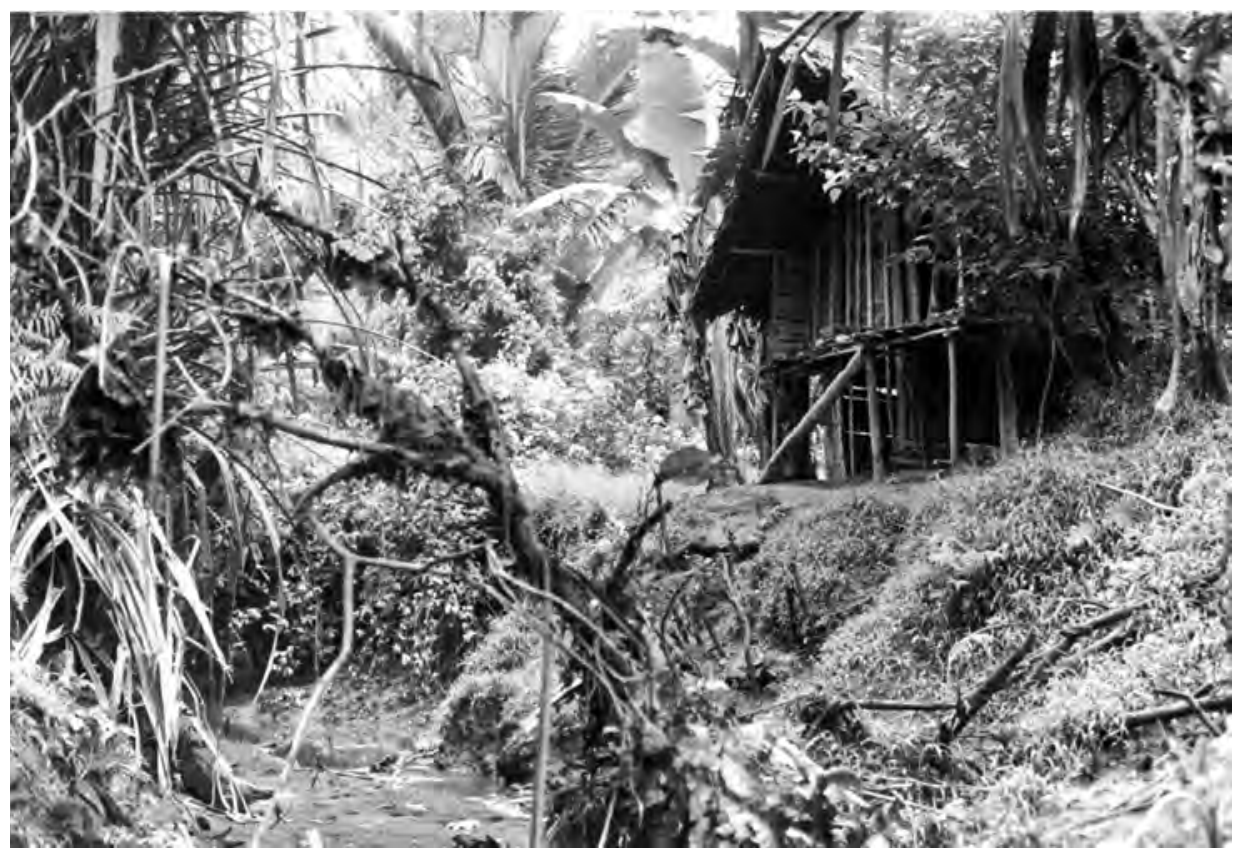

Photo 7: Bush house near Hegeso village, c. 1980. 


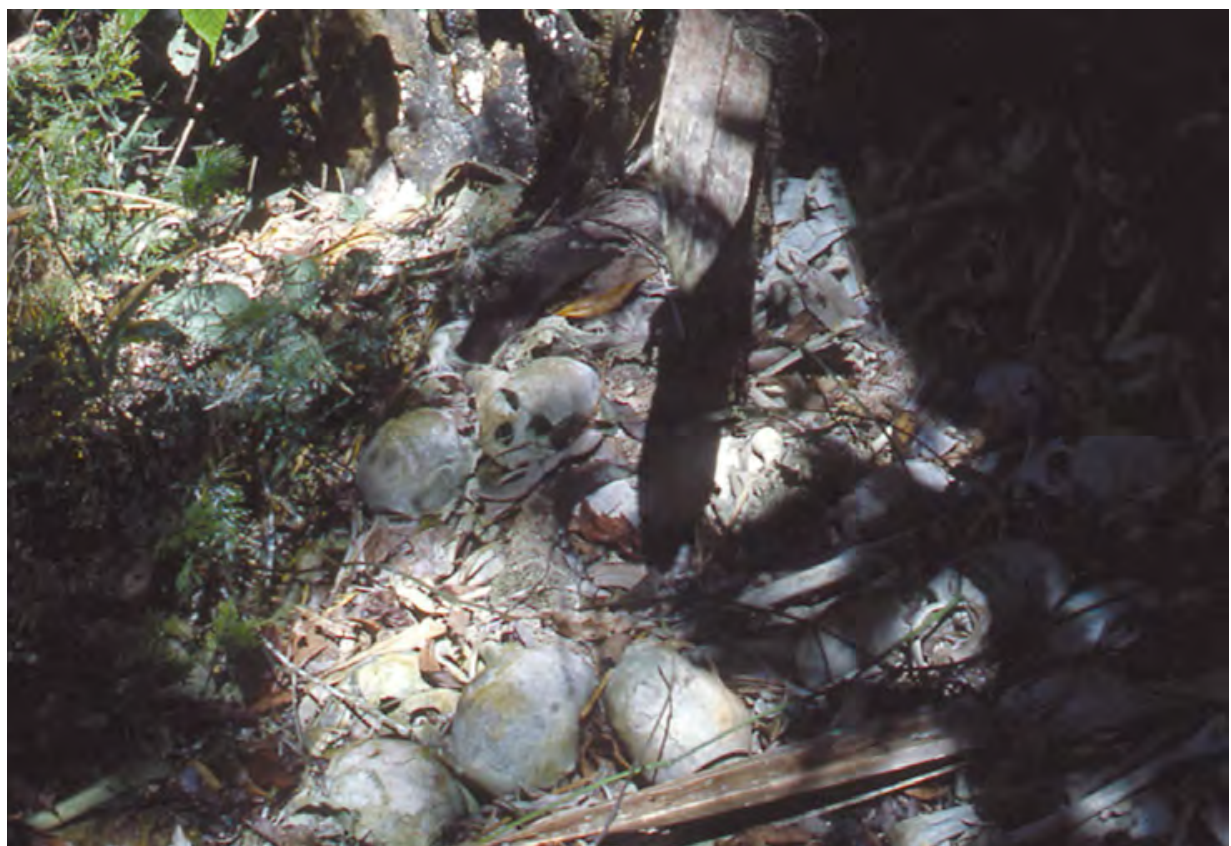

Photo 8: Rock ledge near Segemi Creek, place of the storage of bones of deceased Hegeso men, c. 1980.

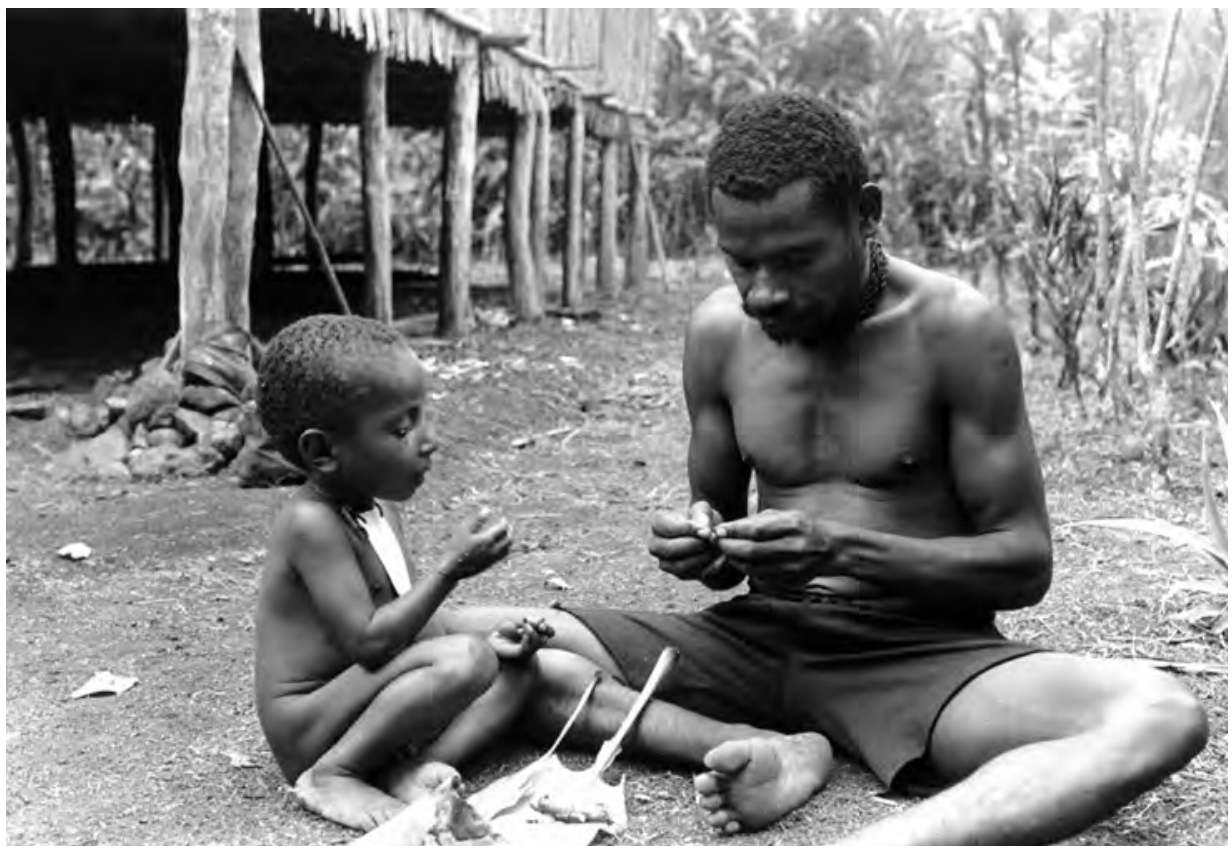

Photo 9: Viya and his son Sese, eating sago grubs near Hegeso longhouse, c. 1980. 


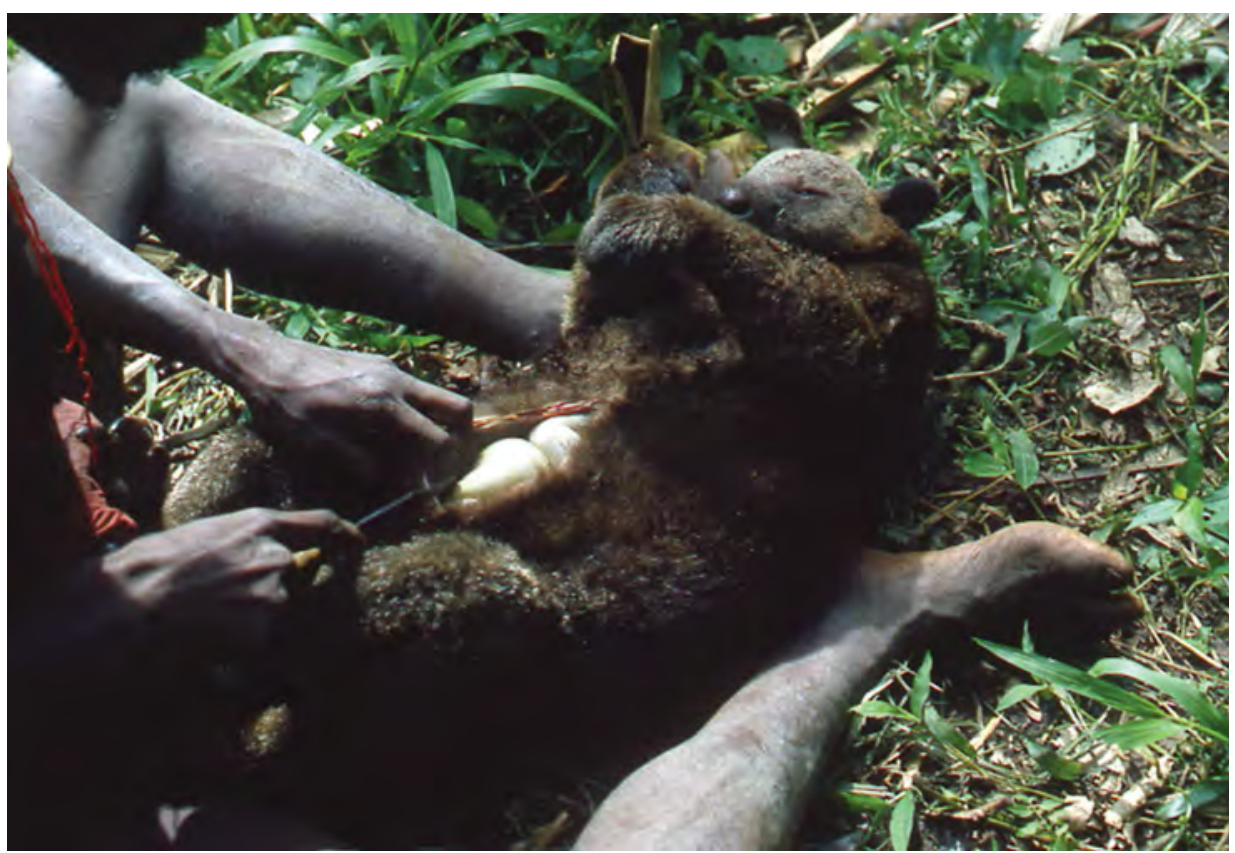

Photo 10: Large marsupial being butchered on a hunting trip to Ayamo, Hegeso village hunting area, c. 1980.

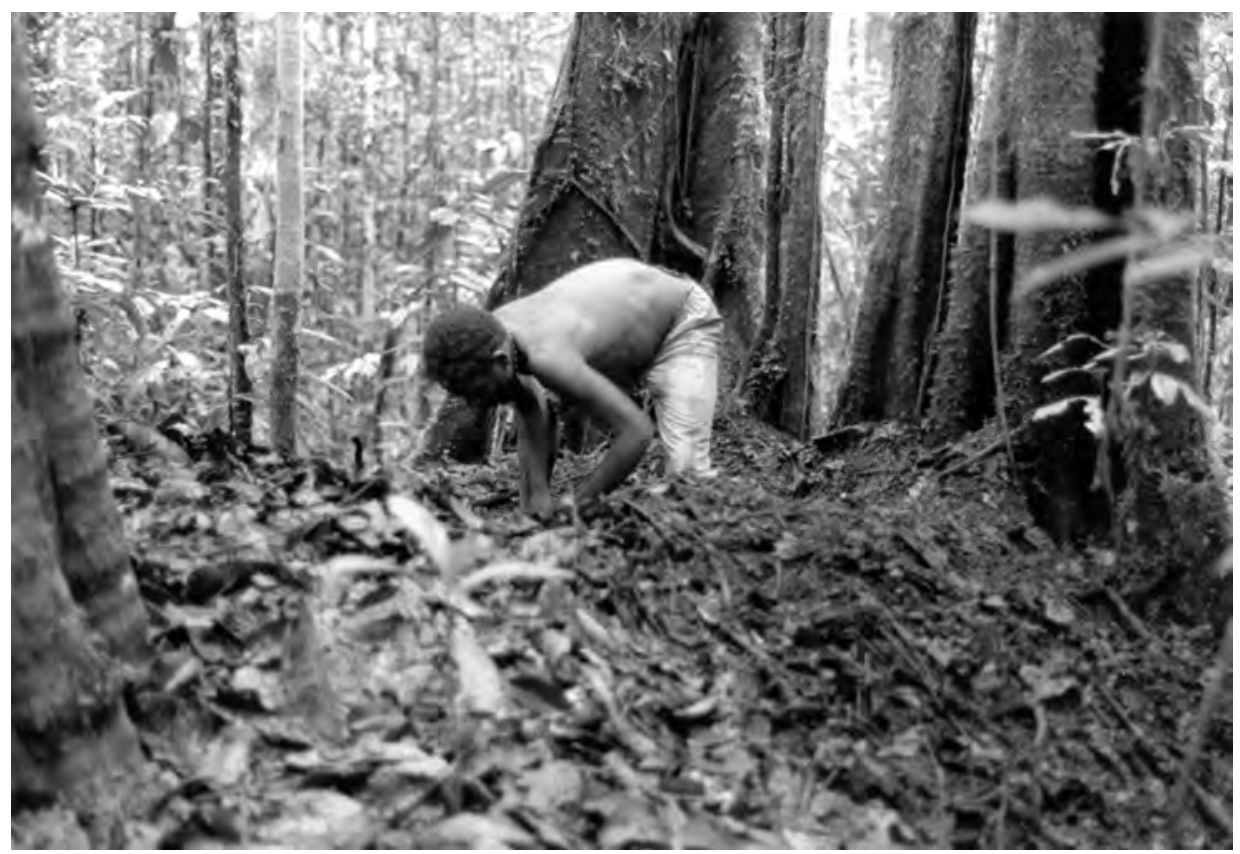

Photo 11: Kora of Hegeso searching for bush-fowl eggs, c. 1980. 


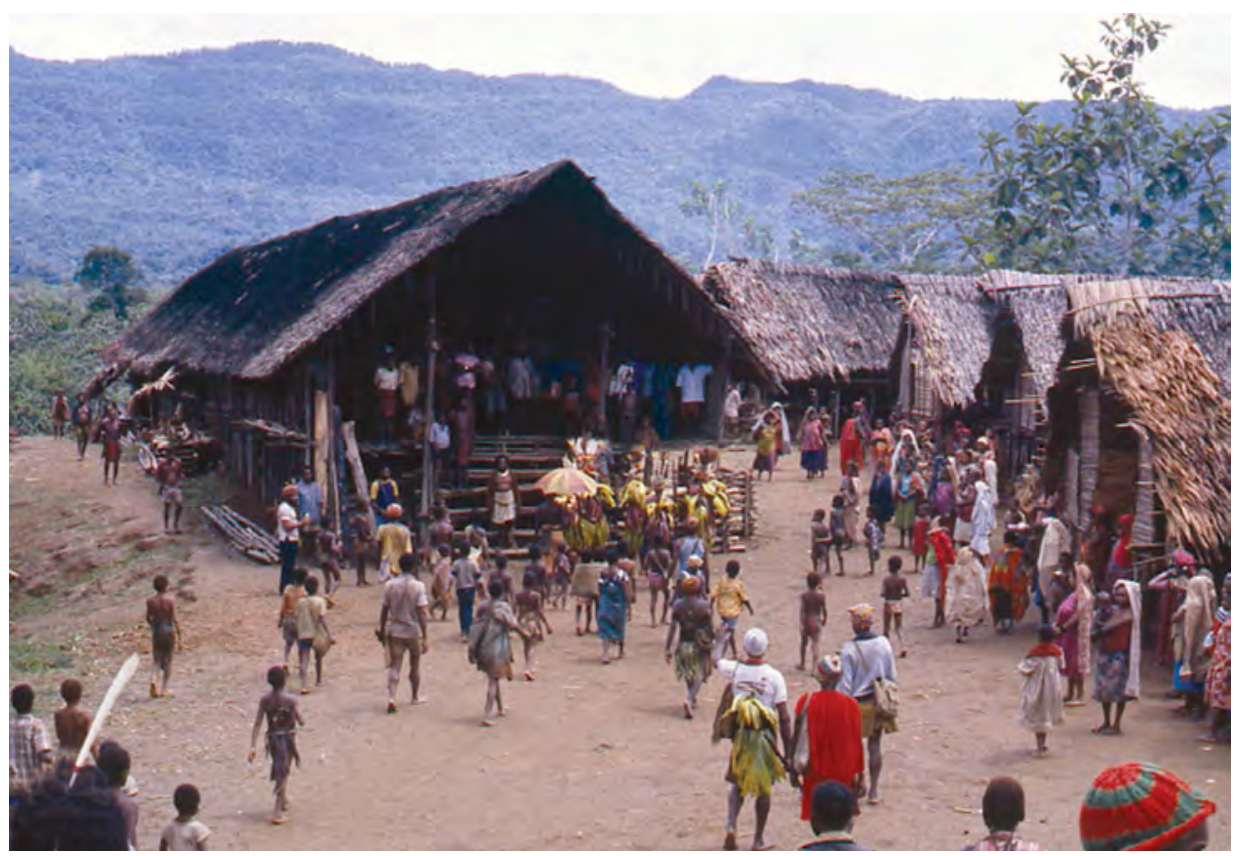

Photo 12: Herebo longhouse, 1980.

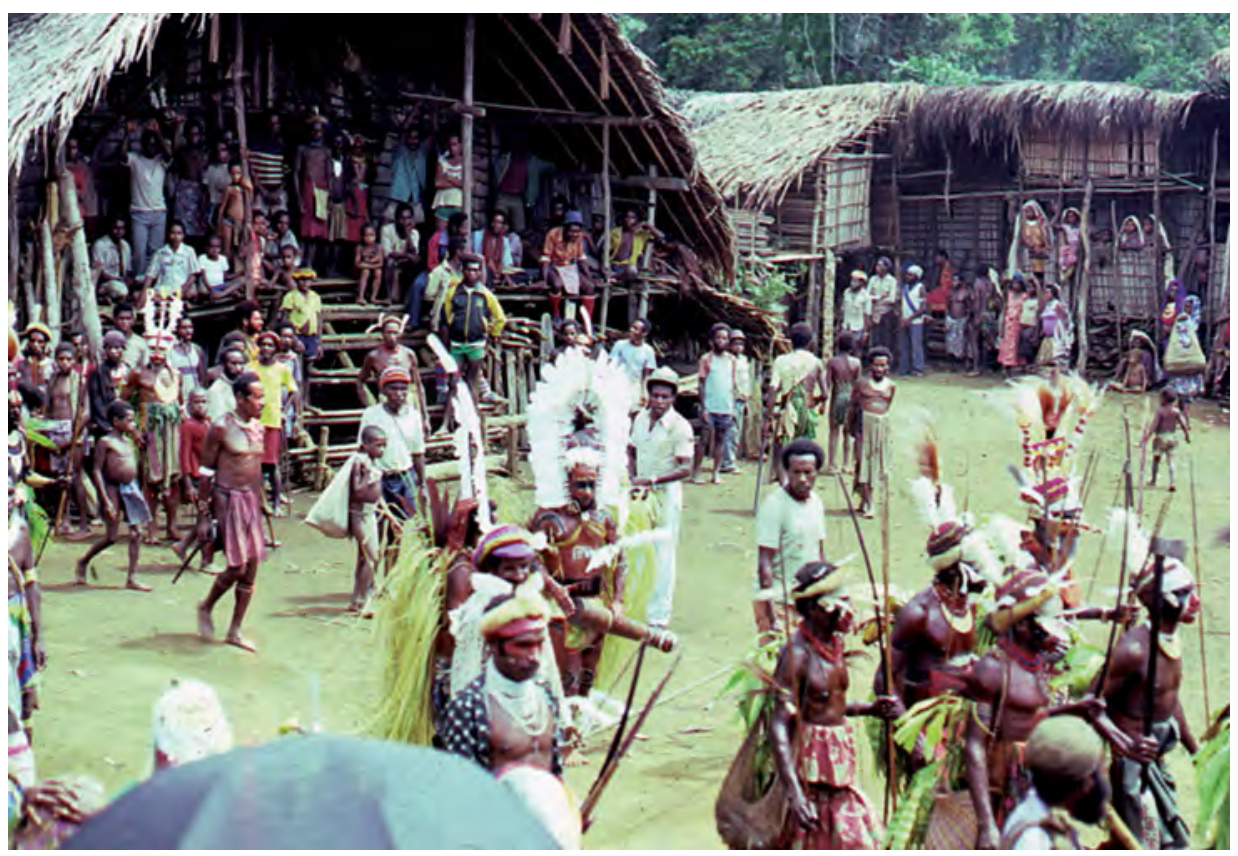

Photo 13: Dancers outside of Herebo longhouse, 1980. 


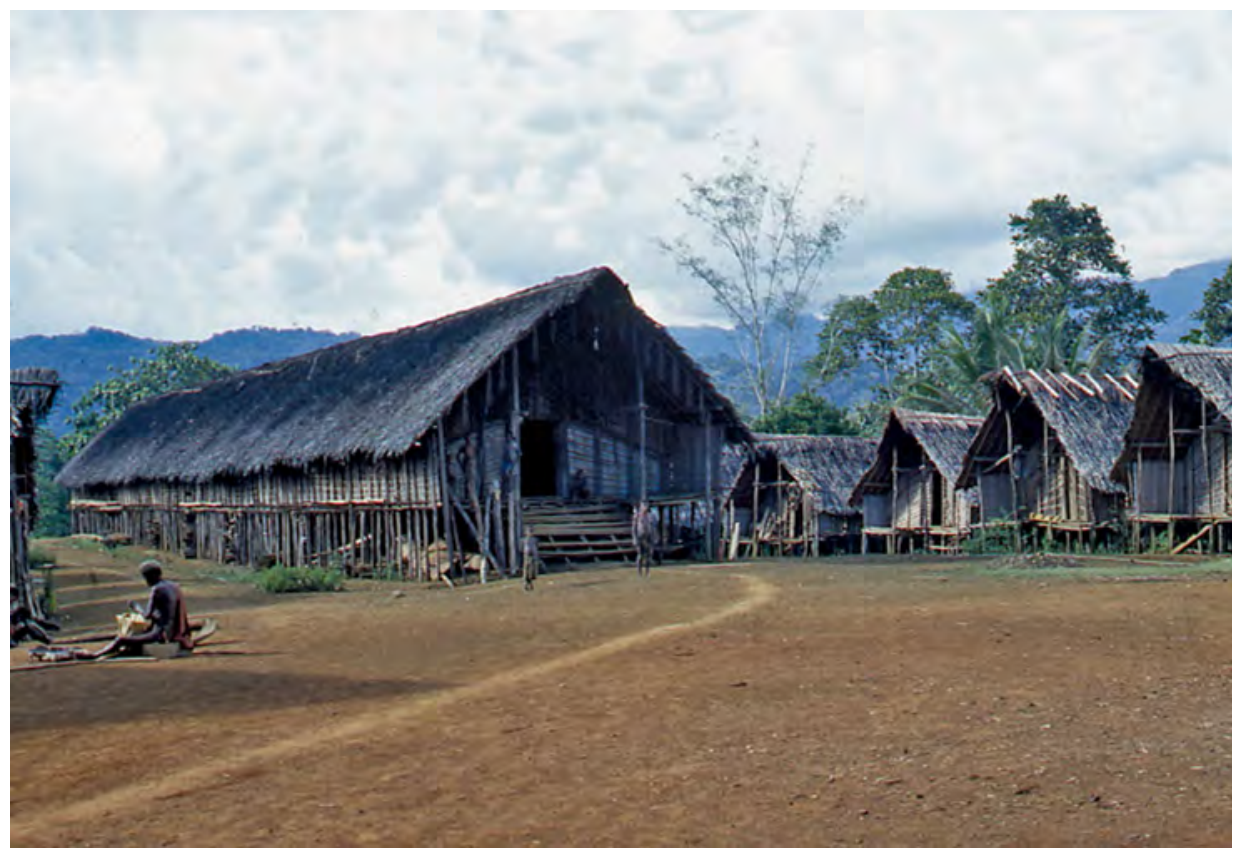

Photo 14: Hegeso longhouse, c. 1980.

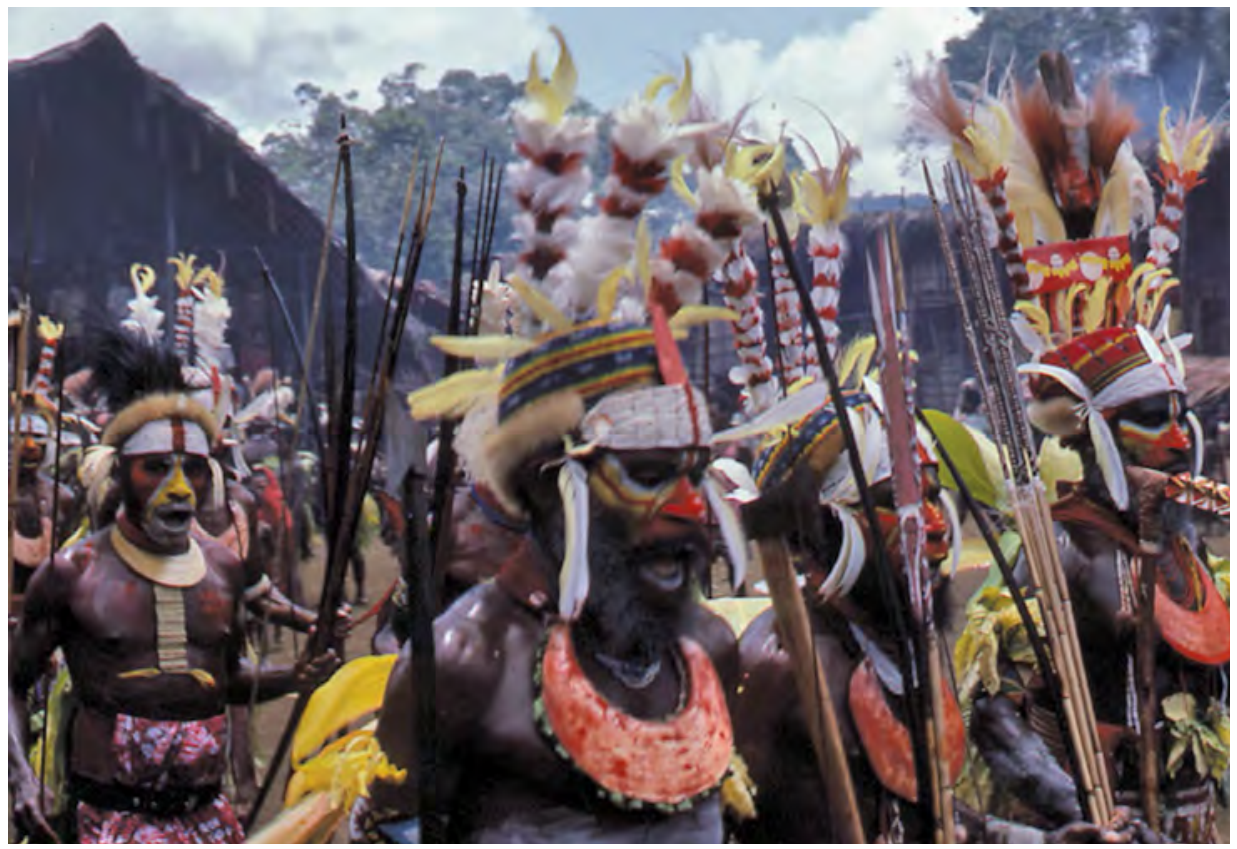

Photo 15: Decorated Foi men at Hegeso Dawa (pig-kill), c. 1980. 


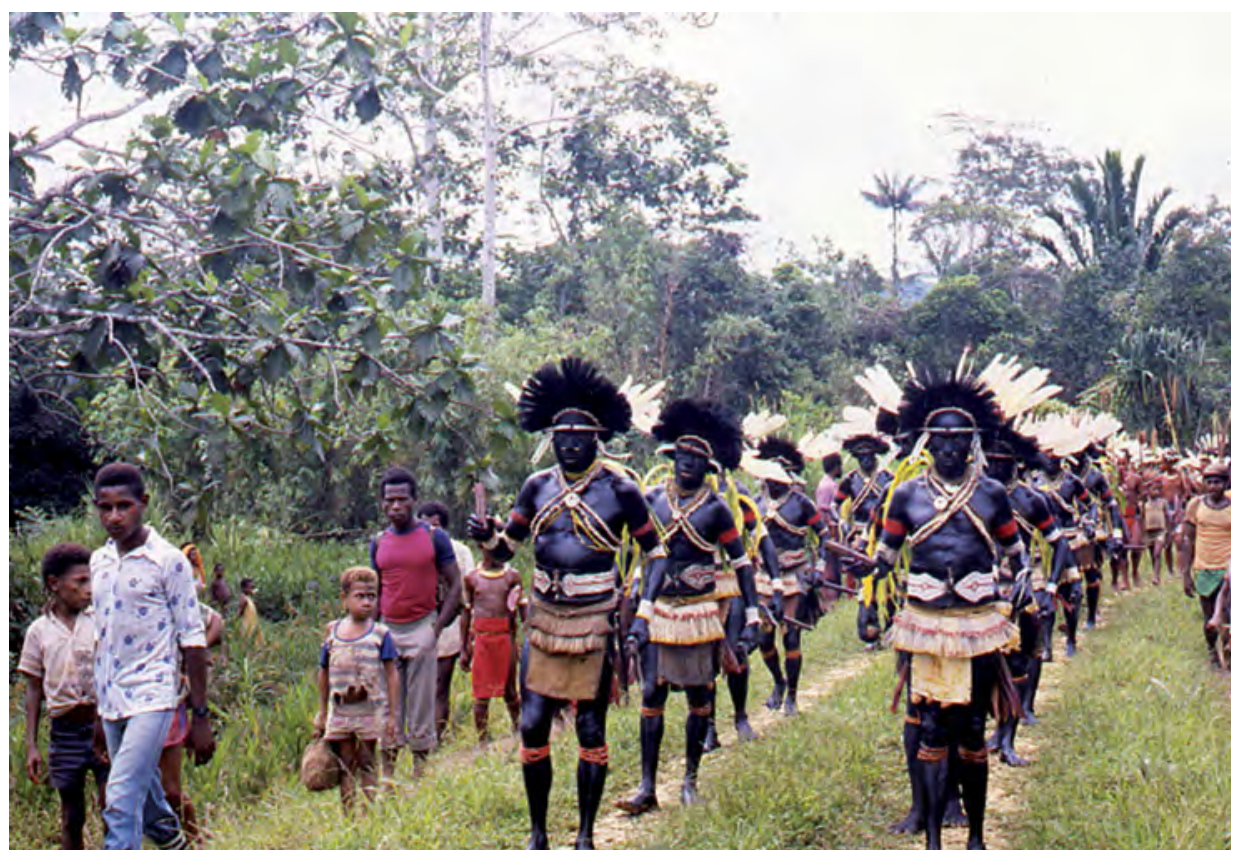

Photo 16: Contingent of decorated Fasu men, arriving at Hegeso Dawa, c. 1980 .

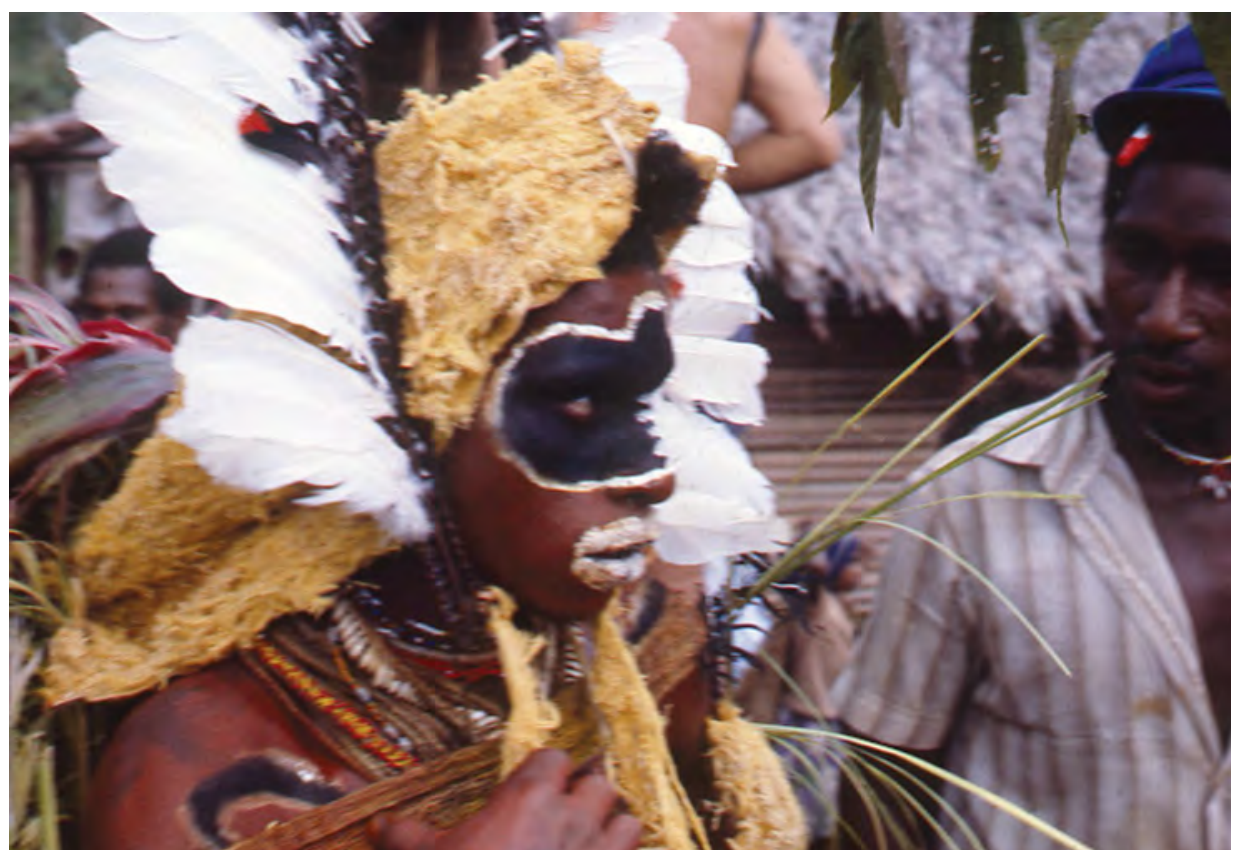

Photo 17: Fasu man in Bosavi-style ceremonial dress, c. 1980. 


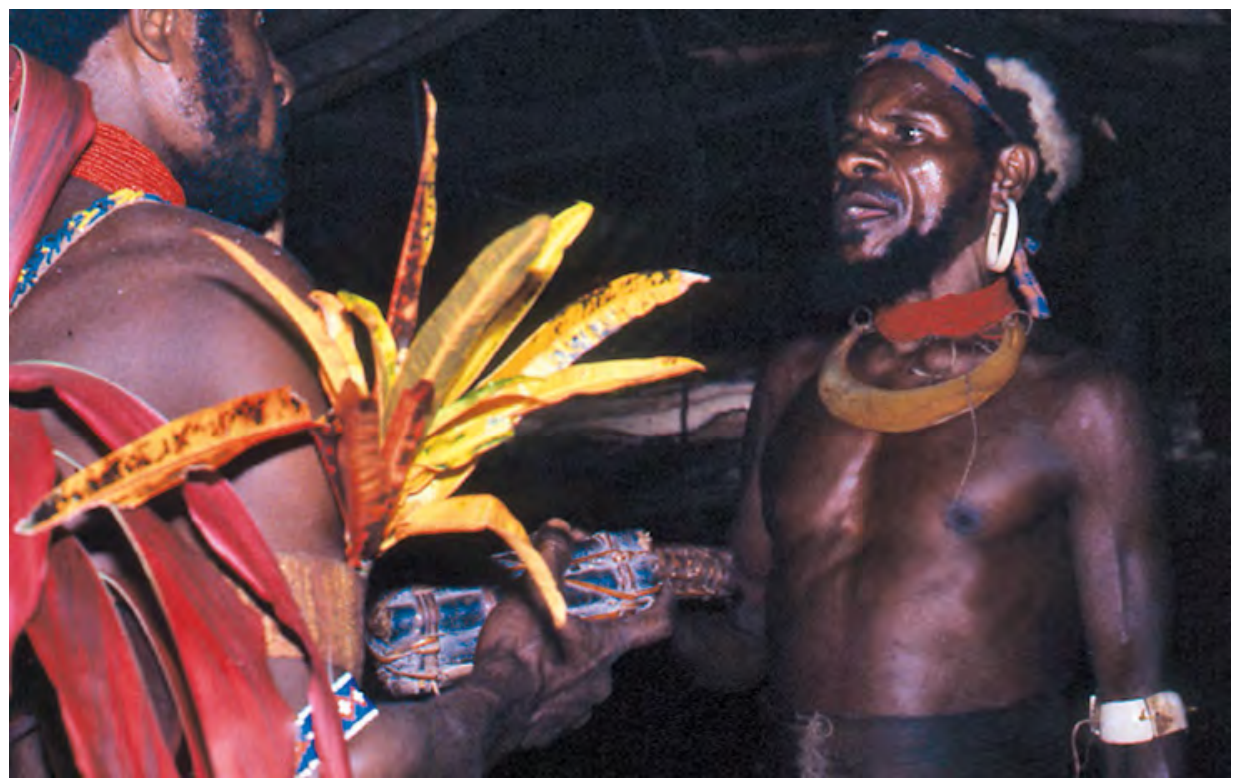

Photo 18: Hegeso men, sorohabora performance, 1980.

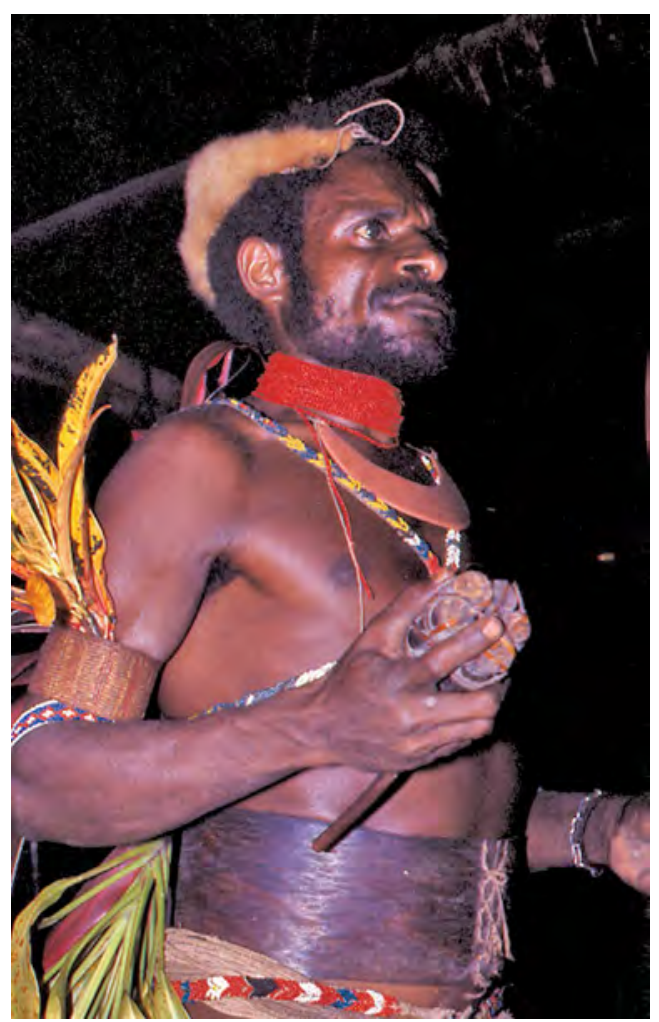

Photo 19: Abeabo of Hegeso, holding a gasore rattle during Hegeso sorohabora, c. 1980. 


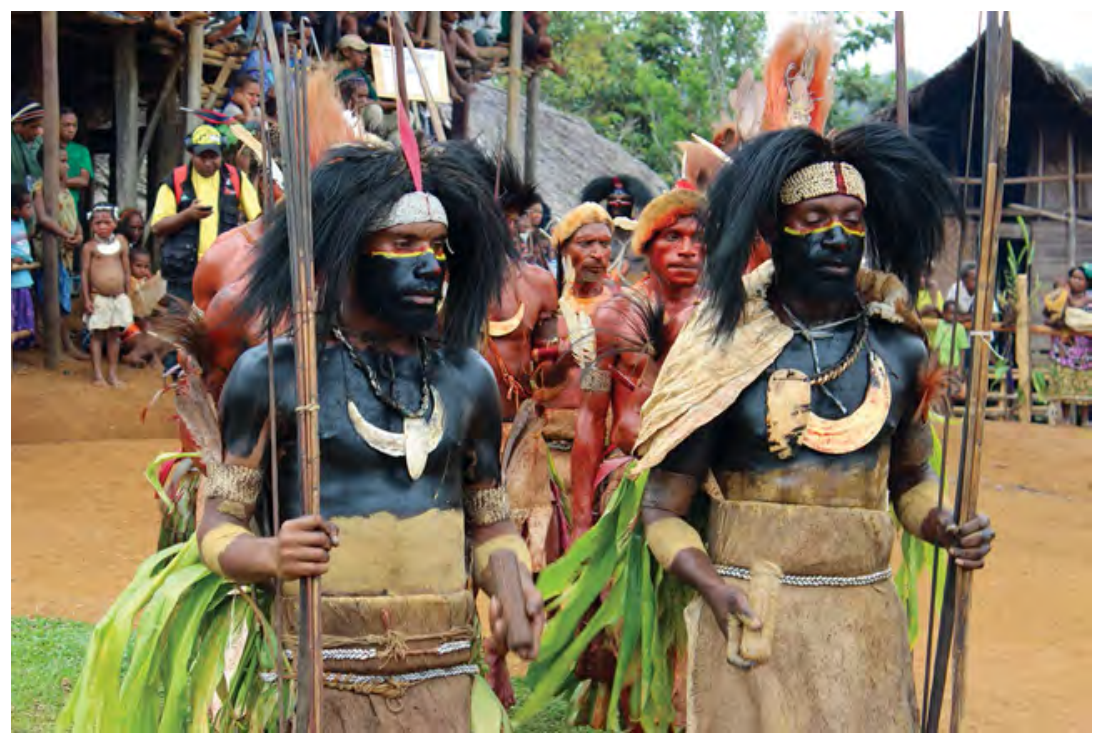

Photo 20: Men playing gasore rattles during the 3rd Kundu and Digaso Festival, Daga village, 20 September 2013. Photo by Don Niles.

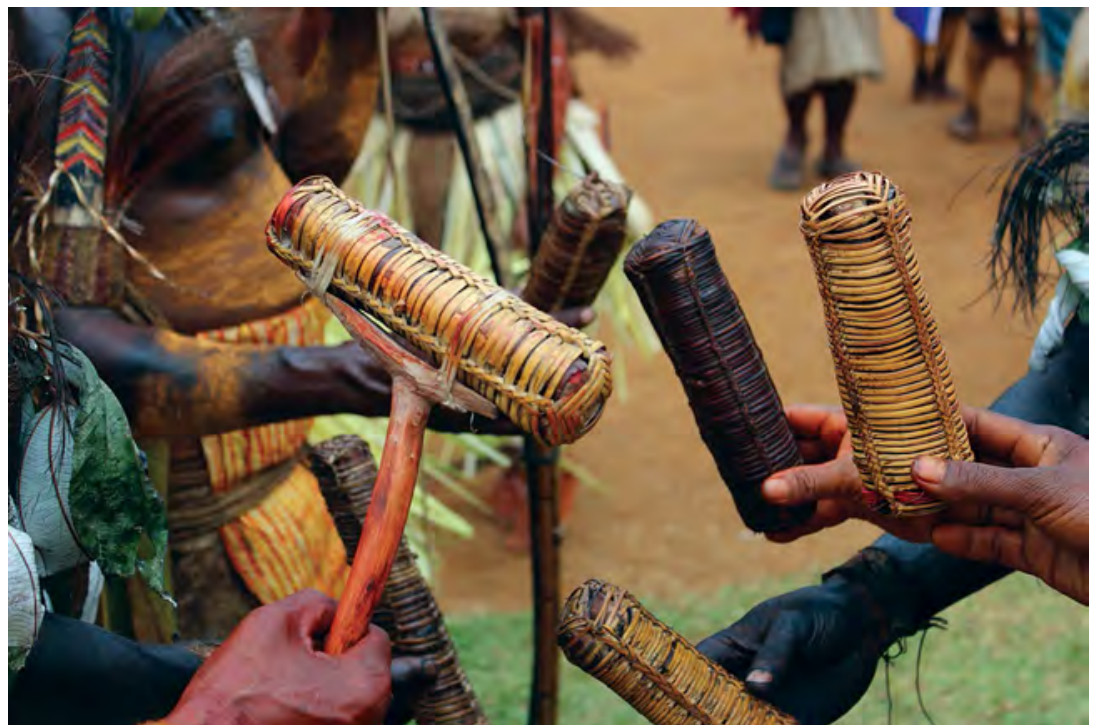

Photo 21: A variety of gasore rattles played during the 3rd Kundu and Digaso Festival, Daga village, 20 September 2013. The instrument at left centre has a handle. Photo by Don Niles. 



\section{References}

Aerts, Theo, and Karl Hesse. 1979. Baining Dances. Boroko: Institute of Papua New Guinea Studies.

Aikhenvald, Alexandra Y. 2014. "'Double Talk": Parallel Structures in Manambu Songs, and Their Origin.' Language and Linguistics in Melanesia 32/2: 86-109.

Austen, Leo. 1934. 'The Dance of the Gope in Kerewo.' Man 34: 4-8.

1936. 'Head Dances of the Turama River.' Oceania 6: 342-49.

Baldwin, Bernard. 1945. 'Usituma! Song of Heaven.' Oceania 15 (March): 201-38.

- 1950. 'Kadaguwai: Songs of the Trobriand Sunset Isles.' Oceania 20: $263-85$.

Barton, F. R. 1910. 'The Annual Trading Expedition to the Papuan Gulf.' In The Melanesians of British New Guinea, by Charles G. Seligman, 96-120. Cambridge: Cambridge University Press.

Bateson, Gregory. 1932. 'Social Structure of the Iatmül People of the Sepik River.' Oceania 2: 245-91, 401-53.

Beaver, Wilfred N. 1920. Unexplored New Guinea. Philadelphia: Lippincott.

Bergmann, H. F. W. 1971. The Kamanuku. 4 vols. Harrisville, Australia.

Borchard, Terrance, and Philip Gibbs. 2011. 'Parallelism and Poetics in Tindi Narratives Sung in the Ipili Language.' In Sung Tales from the Papua New Guinea Highlands: Studies in Form, Meaning, and Sociocultural Context, edited by Alan Rumsey and Don Niles, 165-96. Canberra: ANU E Press.

Brash, Elton, and Nigel Krauth. 1973. Eds. Traditional Poems, Chants and Songs of Papua New Guinea. Papua Pocket Poets, 38. Port Moresby: [n.p.].

Brooksbank, John. 2012. 'Longhouse Communities: Coping with Change.' Paradise 5 (2012): 70-76.

Brown, D. J. J. 1979. 'The Structuring of Polopa Feasting and Warfare.' Man n.s. 14: 712-33.

Brown, Herbert A. 1968. A Dictionary of Toaripi with English-Toaripi Index. 2 vols. Oceania Linguistic Monographs, 11. Sydney: University of Sydney.

Brumbaugh, Robert. 1979. 'A Secret Cult in the West Sepik Highlands.' $\mathrm{PhD}$ dissertation, State University of New York, Stony Brook. 
- 1990. 'Afek Sang: The 'Old Woman' Myth of the Mountain-Ok.' In Children of Afek: Tradition and Change among the Mountain-Ok of Central New Guinea, edited by Barry Craig and David Hyndman, 54-87. Oceania Monograph, 40. Sydney: University of Sydney.

Bulmer, Ralph. 1967. 'Why Is the Cassowary Not a Bird? A Problem of Zoological Taxonomy among the Karam of the New Guinea Highlands.' Man 2: 5-25.

Busse, Mark, Susan Turner, and Nick Araho. 1993. The People of Lake Kutubu and Kikori: Changing Meanings of Daily Life. [Port Moresby]: Papua New Guinea National Museum and Art Gallery.

Chenoweth, Vida. 1979. The Usarufas and Their Music. SIL Museum of Anthropology Publication, 5. Dallas: SIL Museum of Anthropology.

- 2000. Sing-Sing: Communal Singing and Dancing in Papua New Guinea. Christchurch: Macmillan Brown Centre for Pacfic Studies.

Chenoweth, Vida, and Bruce Hooley. 2010. 'Buang Music.' Kulele 4: 111-41.

Clay, Brenda Johnson. 1986. Mandak Realities; Person and Power in Central New Ireland. New Brunswick: Rutgers University Press.

Cooper, Russell E. 1975. 'Coastal Suau: A Preliminary Study of Internal Relationships.' In Studies in Language of Central and South-East Papua, edited by Tom E. Dutton, 227-78. Pacific Linguistics, C 29. Canberra: The Australian National University.

Coulter, Neil R. 2007. 'Music Shift: Evaluating the Vitality and Viability of Music Styles among the Alamblak of Papua New Guinea.' PhD dissertation, Kent State University.

Craig, Barry. 2010. Ed. Living Spirits with Fixed Abodes: The Masterpieces Exhibition, Papua New Guinea National Museum and Art Gallery. Adelaide: Crawford House Publishing Australia.

Crawford, Anthony L. 1981. Aida: Life and Ceremony of the Gogodala. Bathurst: National Cultural Council and Robert Brown \& Associates.

Depew, Robert. 1983. 'Musical Traditions of the Upper Fly River Papua New Guinea.' 74 pp. Music Archive, Institute of Papua New Guinea Studies.

Donohoe, Patricia Mary. 1987. 'Breath of Dirima: A Research Project.' MA thesis, University of New South Wales. 
Drüppel, Birgit. 2009. Re-counting Knowledge in Song: Change Reflected in Kaulong Music. Edited by Don Niles. With one compact disc. Apwitihire: Studies in Papua New Guinea Musics, 10. Boroko: Institute of Papua New Guinea Studies.

Fajans, Jane. 1985. 'They Make Themselves: Life Cycle, Domestic Cycle and Ritual among the Baining.' PhD dissertation, Stanford University.

Feld, Steven. 1978. 'To Make Men Cry: The Poetry of Heyalo.' Gigibori 4: 14-17. . 1981. Music of the Kaluli. Institute of Papua New Guinea Studies IPNGS 001. One $30 \mathrm{~cm}, 33 \mathrm{l} / 3 \mathrm{rpm}$ disc.

-1982. Sound and Sentiment: Birds, Weeping, Poetics, and Song in Kaluli Expression. Publications of the American Folklore Society, New Series. Philadelphia: University of Pennsylvania Press.

. 1985. The Kaluli of Papua Niugini; Weeping and Song. BärenreiterMusicaphon BM 30 SL 2702. One $30 \mathrm{~cm}, 33$ 1/3 rpm disc.

. 1988. 'Aesthetics as Iconicity of Style, or, "Lift-Up-Over-Sounding": Getting into the Kaluli Groove.' Yearbook for Traditional Music 20: 74-113.

-1990. Sound and Sentiment: Birds, Weeping, Poetics, and Song in Kaluli Expression. 2nd ed. Publications of the American Folklore Society, New Series. Philadelphia: University of Pennsylvania Press.

- 2001. Bosavi: Rainforest Music from Papua New Guinea. Smithsonian Folkways Recordings SFW CD 40487. Three CDs.

—. 2015. Email to Don Niles (28 January).

Flanagan, James. 1983. 'Wovan Social Organization.' PhD dissertation, University of Pennsylvannia.

Fortune, Reo F. 1932. Sorcerers of Dobu. New York: Dutton.

Fox, James J. 1977. 'Roman Jakobson and the Comparative Study of Parallelism.' In Roman Jakobson: Echoes of His Scholarship, edited by Daniel Armstrong and Cornelis H. van Schooneveld, 59-90. Lisse: Peter de Ridder Press.

Franklin, Karl J. 1970. 'Metaphorical Songs in Kewa.' In Pacific Linguistic Studies in Honour of Arthur Capell, edited by Stephan A. Wurm and Donald C. Laycock, 985-95. Pacific Linguistics, C 13. Canberra: The Australian National University. 
. 1978. 'Songs in Kewa.' In A Kewa Dictionary, edited by Karl J. Franklin and Joice Franklin, 389-97. Pacific Linguistics, C 53. Canberra: The Australian National University.

Gende, Edward. 1998. 'Highland Region of Papua New Guinea: Chimbu Province: Kuman.' In Australia and the Pacific Islands, edited by Adrienne L. Kaeppler and J. W. Love, 522-26. The Garland Encyclopedia of World Music, 9. New York: Garland Publishing.

Gibbs, Philip. 2001. 'Ol Singsing Enga.' Kulele: Occasional Papers on Pacific Music and Dance 3: 50-63.

. 2011. 'Enga Tindi Pii: The Real World and Creative Imagination.' In Sung Tales from the Papua New Guinea Highlands: Studies in Form, Meaning, and Sociocultural Context, edited by Alan Rumsey and Don Niles, 151-65. Canberra: ANU E Press.

Gillespie, Kirsty. 2010. Steep Slopes: Music and Change in the Highlands of Papua New Guinea. Canberra: ANU E Press.

Gillespie, Kirsty, and Lila San Roque. 2011. 'Music and Language in Duna Pikono.' In Sung Tales from the Papua New Guinea Highlands: Studies in Form, Meaning, and Sociocultural Context, edited by Alan Rumsey and Don Niles, 49-64. Canberra: ANU E Press.

Goldman, Laurence R. 2007. 'Decorated Being in Huli: Parleying with Paint.' In Body Arts and Modernity, edited by Elizabeth Ewart and Michael O'Hanlon, 142-64. Wantage: Sean Kingston Publishing.

Goodale, Jane C. 1995. To Sing with Pigs Is Human: The Concept of Person in Papua New Guinea. Seattle: University of Washington Press.

Graf, Walter. 1950. Die musikwissenschaftlichen Phonogramme Rudolf Pöchs von der Nordküste Neuguineas: Eine materialkritische Studie unter besonderer Berücksichtigung der völkerkundlichen Grundlagen. Rudolf Pöchs Nachlass, B 2. Wien: Rudolf M. Rohrer.

Grove, Theodore Charles. 1978. 'Jaw's Harp Music of Papua New Guinea's Kalam People - the Gwb.' PhD dissertation, Univesity of California, San Diego.

Harrison, Simon. 1982. Laments for Foiled Marriages: Love-songs from a Sepik River Village. Boroko: Institute of Papua New Guinea Studies.

. 1986. 'Laments for Foiled Mard
Village.' Oceania 56 (June): 275-93. 
Hays, Terence E. 1993. "“The New Guinea Highlands": Region, Culture Area, or Fuzzy Set?' Current Anthropology 34 (April): 141-64.

Heeschen, Volker. 1990. Ninye bún: Mythen, Erzählungen, Lieder und Märchen der Eipo im zentralen Bergland von Irian Jaya (West-Neuguinea), Indonesien. Beitrag zur Schriftenreihe 'Mensch, Kultur und Umwelt im zentralen Bergland von West-Neuguinea', 20. Berlin: Dietrich Reimer Verlag.

Helfert, Roy, and David Holdsworth. 1974. Songs of Papua New Guinea. Milton: Jacaranda Press. With one 18 cm, 33 1/3 rpm disc, Jacaranda OCW 1011. (IPNGS c80-141).

Hoenigman, Darja. in prep. 'Language Variation and Social Identity in Kanjimei, East Sepik Province, Papua New Guinea.' PhD dissertation, The Australian National University.

Hooley, Bruce A. 1987. 'Central Buang Poetry.' In Perspectives on Language and Text: Essays and Poems in Honour of Francis I. Andersen's Sixtieth Birthday, edited by Edgar W. Conrad and Edward G. Newing, 71-88. Winona Lake, Indiana: Eisenbrauns.

Huguet, Pierre. 1992. Confluences: Papua New-Guinea: Sounds of Nature and Songs of Stone-Age Men. Pithys 10102. CD.

Ingemann, Frances. 1968. 'The Linguistic Structure of an Ipili-Paiyala Song Type.' 6 pp. Paper presented at the 8th International Congress of Anthropological and Ethnological Sciences, Tokyo.

- 2011. 'The Structure of Chanted Ipili Tindi.' In Sung Tales from the Papua New Guinea Highlands: Studies in Form, Meaning, and Sociocultural Context, edited by Alan Rumsey and Don Niles, 197-206. Canberra: ANU E Press.

Jakobson, Roman. 1960. 'Closing Statement: Linguistics and Poetics.' In Style in Language, edited by Thomas A. Sebeok, 350-77. Cambridge: Massachusetts Institute of Technology.

James, Graham G. 1978. 'An Introduction to the Music of the Cape Nelson Area, Northern Province, Papua New Guinea.' Thesis submitted as part of miscellaneous course, Queensland University.

Jenness, Diamond, and A. Ballantyne. 1926-29. 'Language, Mythology and Songs of Bwaidoga.' Journal of the Polynesian Society 35: 290-314 + map; 36: 48-71, 145-79, 207-238, 303-329; 37: 30-56, 139-64, 271-99, 377-402; 38: 29-47. 
- 1928. Language, Mythology, and Songs of Bwaidoga, Goodenough Island, S.E. Papua. Memoirs of the Polynesian Society, 8. New Plymouth: Thomas Avery \& Sons. [Originally published in the Journal of the Polynesian Society 35-38 (1926-29).]

Jimben, Anna. 1984. 'Karim Lek Songs of the Mid-Wangi [sic] People.' Bikmaus 5 (September): 86-87. [Note: the author's name is incorrectly printed as 'Jinben'.]

Josephides, Lisette. 1982. 'Kewa Stories and Songs (Southern Highlands Province).' Oral History 10: 1-86.

Kasaipwalova, John. 1978. Yaulabuta, Kolupa, deli Lekolekwa (Pilatolu Kilivila Wosimwaya). Port Moresby: Institute of Papua New Guinea Studies.

Kasaipwalova, John, and Ulli Beier. 1978a. Eds. Lekolekwa: An Historical Song from the Trobriand Islands. Port Moresby: Institute of Papua New Guinea Studies.

- 1978b. Eds. Yaulabuta: The Passion of Chief Kailaga; An Historical Poem from the Trobriand Islands. Port Moresby: Institute of Papua New Guinea Studies.

. 1979. 'Exile: An Historical Poem from the Trobriand Islands.' Gigibori 4 (August): 47-48.

Kelsey, John. 1993. 'The Music of the Irumu People, Morobe Province, Papua New Guinea.' PhD dissertation, Wesleyan University.

Kendoli, Kenny Yuwi. 2011. 'Yuna Pikono.' In Sung Tales from the Papua New Guinea Highlands: Studies in Form, Meaning, and Sociocultural Context, edited by Alan Rumsey and Don Niles, 39-48. Canberra: ANU E Press.

Kerema, Philip. 1976? 'Traditional Songs of Ialibu, S.H.P.' 14 pp. Music Archive, Institute of Papua New Guinea Studies.

Kirsch, Stuart. 1987. 'Preliminary Notes on the Musical Traditions of the Yongom.' 7 pp. Music Archive, Institute of Papua New Guinea Studies.

Knauft, Bruce M. 1985a. Good Company and Violence: Sorcery and Social Action in a Lowland New Guinea Society. Studies in Melanesian Anthropology, 3. Berkeley: University of California.

. 1985b. 'Ritual Form and Permutation in New Guinea: Implications of Symbolic Process for Socio-Political Evolution.' American Ethnologist 12 (May): 321-40. 
. 2005. The Gebusi: Lives Transformed in a Rainforest World. Boston: McGraw-Hill.

2012. 'Gebusi Music and Dance 1980-92.' http://www.anthropology. emory.edu/faculty/antbk/gebusiResearch/gebusi_music_dance.html (accessed 2 May 2012).

Koyati, Peandui. 1979. 'Traditional Songs of the Baiyer River.' Oral History 7: 42-106.

Laba, Billai, Thomas Lulungan, James Jesse Pongap, and Don Niles. 1980. 'Texts, Translations, and Additional Commentaries on IPNGS Recordings, Part I.' Oral History 8: 91-100.

Landtman, Gunnar. 1913. 'The Poetry of the Kiwai Papuans.' Folklore 24: 284-313.

- 1927. The Kiwai Papuans of British New Guinea. London: Macmillan.

Laycock, Donald C. 1969a. Akaru: Traditional Buin Songs. Papua Pocket Poets, 12. Port Moresby: [n.p.].

—. 1969b. 'Buin Songs.' Kovave 1 (November): 5-8.

- 1969c. 'Sublanguages in Buin: Play, Poetry, and Preservation.' In Papers in New Guinea Linguistics, 10, 1-23. Pacific Linguistics, A 22. Canberra: The Australian National University.

- 1970. 'The Content of Buin Songs Today.' Paper read at Section 25, ANZAAS Conference, Port Moresby, August 1970.

_. 1972. 'Two Buin Songs.' Kovave 3 (June): 23-24.

LeRoy, John. 1978. 'Burning Our Trees: Metaphors in Kewa Songs.' Yearbook of Symbolic Anthropology 1: 51-72.

- 1985. Fabricated World: An Interpretation of Kewa Tales. Vancouver: University of British Columbia Press.

Lewis, Gilbert. 1980. Day of Shining Red: An Essay on Understanding Ritual. Cambridge Studies in Social Anthropology, 27. Cambridge: Cambridge University Press.

Lewis, M. Paul, Gary F. Simons, and Charles D. Fennig. 2013. Eds. Ethnologue: Languages of the World. 17th ed. Dallas: SIL International. Online version: http://www.ethnologue.com/. 
Lomas, Gabe C. J. 2011. 'Sung Tales in Héla Húli.' In Sung Tales from the Papua New Guinea Highlands: Studies in Form, Meaning, and Sociocultural Context, edited by Alan Rumsey and Don Niles, 75-108. Canberra: ANU E Press.

Luzbetak, Louis J. 1954. 'The Socio-Religious Significance of a New Guinea Pig Festival.' Anthropological Quarterly 2: 59-80, 102-28.

MacDonald, Mary N. 1991. Mararoko: A Study in Melanesian Religion. American University Studies, 9, 45. New York: Peter Lang.

May, Jean, and Eunice Loeweke. 1981. Fasu (Námo Mē)-English Dictionary. Ukarumpa: Summer Institute of Linguistics.

Mimica, Jadran. 1993. 'Review Article: The Foi and Heidegger: Western Philosophical Poetics and a New Guinea Life-World.' Australian Journal of Anthropology 4: 79-95.

Moyle, Richard M. 2007. Songs from the Second Float: A Musical Ethnography of Takū Atoll, Papua New Guinea. Pacific Islands Monograph Series, 21. Mānoa: Center for Pacific Islands Studies; Honolulu: University of Hawai'i Press.

National. 2012. 'Kutubu Culture Still Uncovered.' The National (25 September): 5.

National Arts School. [1986?]. Igimi: The Biami Tribe. [Boroko]: National Arts School.

Neuhauss, Richard. 1911. Deutsch Neu-Guinea. 3 vols. Berlin: Dietrich Reimer.

Niles, Don. 2000. Papua New Guinea (1904-1909): The Collections of Rudolf Pöch, Wilhelm Schmidt, and Josef Winthuis. Book (223 pp.), five compact discs (OEAW PHA CD 9/1-5), and one CD-ROM (OEAW PHA CDROM/9). Dietrich Schüller, series editor. Gerda Lechleitner, editor. Erna Mack, music transcriptions. Tondokumente aus dem Phonogrammarchiv der Österreichischen Akademie der Wissenschaften: Gesamtsausgabe der Historischen Bestände 1899-1950 / Sound Documents from the Phonogrammarchiv of the Austrian Academy of Sciences: The Complete Historical Collections 1899-1950, series 3. Wien: Verlag der Österreichischen Akademie der Wissenschaften.

2007. 'Sonic Structure in Tom Yaya Kange: Ku Waru Sung Narratives from Papua New Guinea.' In Oceanic Music Encounters - the Print Resource and the Human Resource: Essays in Honour of Mervyn McLean, edited by Richard Moyle, 109-22. Research in Anthropology and Linguistics Monograph, 7. Auckland: University of Auckland. 
. 2009. 'Editor's Introduction.' In Re-counting Knowledge in Song: Change Reflected in Kaulong Music, edited by Birgit Drüppel, xv-xl. Apwitihire: Studies in Papua New Guinea Musics, 10. With one compact disc (IPNGS 013). Boroko: Institute of Papua New Guinea Studies.

. 201la. 'Metric Melodies and the Performance of Sung Tales in the Hagen Area.' In Sung Tales from the Papua New Guinea Highlands: Studies in Form, Meaning, and Sociocultural Context, edited by Alan Rumsey and Don Niles, 275-302. Canberra: ANU E Press.

. 2011b. 'Structuring Sound and Movement: Music and Dance in the Mount Hagen Area.' PhD dissertation, Anthropology and Sociology, University of Papua New Guinea.

Niles, Don, and Edward Gende. 2013. '[Notes accompanying recordings and photos from the 3rd Kundu and Digaso Festival].' Institute of Papua New Guinea Studies Music Archive IPNGS 13-056, 13-057, and 13-059.

Niles, Don, and Alan Rumsey. 2011. 'Introducing Highlands Sung Tales.' In Sung Tales from the Papua New Guinea Highlands: Studies in Form, Meaning, and Sociocultural Context, edited by Alan Rumsey and Don Niles, 1-38. Canberra: ANU E Press.

Niles, Don, and Michael Webb. 1987. Papua New Guinea Music Collection. Boroko: Institute of Papua New Guinea Studies. IPNGS 008. Eleven cassettes and book.

O'Brien, Denise. 1969a. 'The Economics of Dani Marriage: An Analysis of Marriage Payments in a Highland New Guinea Society.' PhD dissertation, Yale University.

. 1969b. 'Marriage among the Konda Valley Dani.' In Pigs, Pearlshells, and Women: Marriage in the New Guinea Highlands, edited by Robert M. Glasse and Mervyn J. Meggitt, 198-234. Englewood Cliffs: Prentice Hall.

Oil Search Limited. 2012. 'Kutubu.' http://www.oilsearch.com/Our-Activities/ PNG/Kutubu.html (accessed 11 May 2012).

Oliver-Berg, Marie H. 1979. 'Music and Meaning of Buin Songs.' BA Honours thesis, University of Queensland.

Oméga Studio. 1981? P.N.G. Oméga Studio OM 67.026. One 30 cm, 33 1/3 rpm disc. (IPNGS c86-110).

Paia, Robert, and Andrew Strathern. 1977. Beneath the Andaiya Tree: Wiru Songs. Boroko: Institute of Papua New Guinea Studies. 
Pawley, Andrew, and Ralph Bulmer. 2011. A Dictionary of Kalam with Ethnographic Notes. With the assistance of John Kias, Simon Peter Gi, and Ian Saem Majnep. Pacific Linguistics, 630. Canberra: The Australian National University.

Petterson, Robert. 1999. Rumu-English-Hiri Motu Dictionary; RumuheiHohei-Mutuheu Hei Ke Tei Kopatë. Occasional Paper, 6. [Palmerston North]: International Pacific College.

Pöch, Rudolf. 1905. 'Beobachtungen über Sprache, Gesänge und Tänze der Monumbo anläßlich phonographischer Aufnahmen in Deutsch-Neu-Guinea.' Mitteilungen der Anthropologischen Gesellschaft in Wien 35 (5): 230-37, Tafel 1.

Pospisil, Leopold. 1963. The Kapauku Papuans of West New Guinea. Case Studies in Cultural Anthropology. New York: Holt, Rinehart \& Winston.

Pugh-Kitingan, Jacqueline. 1981. 'An Ethnomusicological Study of the Huli of the Southern Highlands, Papua New Guinea.' PhD dissertation, University of Queensland.

Rappaport, Roy A. 1968. Pigs for the Ancestors: Ritual in the Ecology of a New Guinea People. New Haven: Yale University Press.

Reesink, Ger P. 1992. Review of The Empty Place: Poetry, Space, and Being among the Foi of Papua New Guinea, by James F. Weiner. Oceanic Linguistics 31(2) (Winter): 310-12.

Reigle, Robert. 1995. 'Sound of the Spirits, Song of the Myna.' In New Guinea Ethnomusicology Conference: Proceedings, edited by Robert Reigle, 121-28. Occasional Papers in Pacific Ethnomusicology, 4. Auckland: University of Auckland.

\section{PhD dissertation, University of California, Los Angeles. With 2 CDs.}

Reithofer, Hans. 2011. 'Skywalkers and Cannibals: Chanted Tales among the Angal.' In Sung Tales from the Papua New Guinea Highlands: Studies in Form, Meaning, and Sociocultural Context, edited by Alan Rumsey and Don Niles, 207-46. Canberra: ANU E Press.

Riley, E. Baxter. 1925. Among Papuan Headhunters. London: Seeley Service.

Roberts, Christopher. 1996. Xingchen Shan li de gong ming: Xin Jineiya zhong bu ge yao 星辰山裡的共鳴 : 新幾內亞中部歌謡 [Music of the Star Mountains: Traditional singing in Central New Guinea]. Translated by Wang Ling-kang 王靈康. Illustrations by Patricia Hills. In Chinese. Taipei: Yuan-Liou. 
. 2014. Music of the Star Mountains: A Naturalist's Guide to the Composition of Songs in Central New Guinea. Edited by Don Niles. With one compact disc. Apwitihire: Studies in Papua New Guinea Musics, 11. Boroko: Institute of Papua New Guinea Studies.

Rule, W. Murray. 1993. The Culture and Language of the Foe: The People of Lake Kutubu, Southern Highlands Province, Papua New Guinea. Commissioned by Chevron Niugini Pty., Ltd., for Kutubu Joint Venture. Merewether, Australia: Murray Rule.

Rumsey, Alan. 1995. 'Pairing and Parallelism in the New Guinea Highlands.' In SALSA II: Proceedings of the Second Annual Symposium about Language and Society, Austin, edited by Pamela Silberman and Jonathan Loftin, 108-18. Texas Linguistic Forum, 34. Austin: University of Texas.

. 2001. 'Tom Yaya Kange: A Metrical Narrative Genre from the New Guinea Highlands.' Journal of Linguistic Anthropology 11: 193-239.

- 2005. 'Chanted Tales in the New Guinea Highlands of Today: A Comparative Study.' In Expressive Genres and Historical Change: Indonesia, Papua New Guinea and Taiwan, edited by Pamela J. Stewart and Andrew Strathern, 41-81. Anthropology and Cultural History in Asia and the IndoPacific. Hants: Ashgate Publishing.

. 2007. 'Musical, Poetic, and Linguistic Form in Tom Yaya Sung Narratives from Papua New Guinea.' Anthropological Linguistics 49: 235-82.

. 2010. 'A Metrical System That Defies Description by Ordinary Means.' In A Journey through Austronesian and Papuan Linguistic and Cultural Space: Papers in Honour of Andrew K. Pawley, edited by John Bowden, Nikolaus P. Himmelmann, Malcolm Ross, and Edgar Suter, 39-56. Pacific Linguistics, 615. Canberra: Pacific Linguistics.

2011. 'Style, Plot, and Character in Tom Yaya Kange Tales from Ku Waru.' In Sung Tales from the Papua New Guinea Highlands: Studies in Form, Meaning, and Sociocultural Context, edited by Alan Rumsey and Don Niles, 247-74. Canberra: ANU E Press.

Sankoff, Gillian. 1977. 'Le parallélisme dans la poésie Buang.' Anthropologica 19: $27-48$.

Schieffelin, Bambi B., and Steven Feld. 1998. Bosavi-English-Tok Pisin Dictionary (Papua New Guinea) / Bosabi towo:liya: Ingilis towo:liya: Pisin towo:liya: bugo: / Tok ples Bosavi, Tok Inglis, na Tok Pisin diksineli. Pacific Linguistics, C 153. Canberra: The Australian National University. 
Schieffelin, Edward L. 1968. 'The Sorrow of the Lonely and the Burning of the Dancers.' Paper read at [Eighth] International Congress of Anthropological and Ethnological Sciences, at Tokyo.

- 1976. The Sorrow of the Lonely and the Burning of the Dancers. New York: St. Martin's Press.

Schmidt-Ernsthausen, Victor. 1890. 'Über die Musik der Eingebornen von Deutsch Neu-Guinea.' Vierteljahrsshrift für Musikwissenschaft (Leipzig) 6: 268-74.

Schmidt, Wilhelm. 1909. 'Über Musik und Gesänge der Karesau-Papuas, Deutsch Neu-Guinea.' In 3. Kongress der Internationalen Musikgesellschaft, Wien, 25. bis 29. Mai 1909, Bericht, 297-98. Wien: Artaria; Leipzig: Breitkopf \& Härtel.

Seligman, Charles G. 1910. The Melanesians of British New Guinea. Cambridge: Cambridge University Press.

Senft, Gunter. 1999. 'The Presentation of Self in Touristic Encounters: A Case Study from the Trobriand Islands.' Anthropos 94/1-3: 21-33.

. 2011. The Tuma Underworld of Love: Erotic and Other Narrative Songs of the Trobriand Islanders and Their Spirits of the Dead. Culture and Language Use: Studies in Anthropological Linguistics, 5. Amsterdam: John Benjamins Publishing Company.

Shaw, R. Daniel. 1975. 'Samo Social Structure: A Socio-Linguistic Approach to Understanding Interpersonal Relationships.' PhD dissertation, University of Papua New Guinea.

. 1982. 'Samo Initiation: Its Context and Its Meaning.' Journal of the Polynesian Society 91 (September): 417-34.

Simon, Artur. 1978. 'Types and Functions of Music in the Eastern Highlands of West Irian.' Ethnomusicology 22: 441-55.

. 1993. Musik aus dem Bergland West-Neuguineas Irian Jaya: Eine Klangdokumentation untergehender Musikkulturen der Eipo und ihrer Nachbarn. Museum für Völkerkunde Collection Berlin CD 20. Six compact discs. (IPNGS c93-200).

Sollis, Michael. 2010. 'Tune-Tone Relationships in Sung Duna Pikono.' Australian Journal of Linguistics 30 (January): 67-80 (special issue, 'The Language of Song'). 
. 2011. 'Parallelism in Duna Pikono.' In Sung Tales from the Papua New Guinea Highlands: Studies in Form, Meaning, and Sociocultural Context, edited by Alan Rumsey and Don Niles, 65-74. Canberra: ANU E Press.

Sørum, Arve. 1980. 'In Search of the Lost Soul: Bedamini Spirit Seances and Curing Rites.' Oceania 50 (June): 273-96.

- 1982. 'The Seeds of Power: Patterns of Bedamini Male Initiation.' Social Analysis 10 (March): 42-62.

Spearritt, Gordon D., and Jürg Wassmann. 1996. 'Myth and Music in a Middle Sepik Village.' Kulele: Occasional Papers on Pacific Music and Dance 2: 59-84.

Steadman, Lyle B. 1971. 'Neighbours and Killers: Residence and Dominance among the Hewa of New Guinea.' PhD dissertation, The Australian National University.

Stella, Regis N. 1990. Forms and Styles of Traditional Banoni Music. Edited by Don Niles. Apwitihire: Studies in Papua New Guinea Musics, 1. Boroko: National Research Institute.

Stewart, Pamela J., and Andrew Strathern. 2002. Gender, Song, and Sensibility: Folktales and Folksongs in the Highlands of New Guinea. Westport: Praeger.

Strathern, Andrew. 1974. Melpa Amb Kenan: Courting Songs of the Melpa People. Boroko: Institute of Papua New Guinea Studies.

- 1988. 'Conclusions: Looking at the Edge of the New Guinea Highlands from the Center.' In Mountain Papuans; Historical and Comparative Perspectives from New Guinea Fringe Highlands Societies, edited by James F. Weiner, 187-212. Ann Arbor: University of Michigan Press.

Strathern, Andrew, and Pamela J. Stewart. 2005. 'Melpa Songs and Ballads: Junctures of Sympathy and Desire in Mount Hagen, Papua New Guinea.' In Expressive Genres and Historical Change: Indonesia, Papua New Guinea and Taiwan, edited by Pamela J. Stewart and Andrew Strathern, 201-33. Anthropology and Cultural History in Asia and the Indo-Pacific. Hants: Ashgate Publishing.

- 2011. 'Bamboo Knives, Bows, and Waterfalls: The Presentation of "Traditional Knowledge" in Melpa Kang Rom, Duna Pikono, and the Works of Hesiod and Virgil.' In Sung Tales from the Papua New Guinea Highlands: Studies in Form, Meaning, and Sociocultural Context, edited by Alan Rumsey and Don Niles, 303-16. Canberra: ANU E Press.

Strathern, Gomb, and Andrew Strathern. 1985. Kintu Songs. Boroko: Institute of Papua New Guinea Studies. 
Talyaga, Kundapen. 1973. Enga Eda Nemago: Meri Singsing Poetry of the Yandapo Engas. Papua Pocket Poets, 40. Port Moresby: [n.p.].

. 1974. 'Five Enga Songs about Missions.' Gigibori 1 (December): 40.

- 1975. Modern Enga Songs. Boroko: Institute of Papua New Guinea Studies.

Telban, Borut. 1998. Dancing through Time: A Sepik Cosmology. Oxford Studies in Social and Cultural Anthropology. Oxford: Clarendon Press.

- 2008. 'The Poetics of the Crocodile: Changing Clutlural Perspectives in Ambonwari.' Oceania 78/2 (July): 217-35.

Thurnwald, Richard. 1912. Forschungen auf den Salomo-Inseln und dem BismarckArchipel; vol. 1: Lieder und Sagen aus Buin. Berlin: Reimer.

- 1936. Profane Literature of Buin, Solomon Islands. Yale University Publications in Anthropology, 8. New Haven: Yale University. . 1941. 'Alte und neue Volkslieder aus Buin.' Zeitschrift für Ethnologie 73: 12-28.

Turner, James West. 1993. Review of The Empty Place: Poetry, Space, and Being among the Foi of Papua New Guinea, by James F. Weiner. Anthropos 88 (1-3): 288-89.

Voorhoeve, C. L. 1977. 'Ta-Poman: Metaphorical Use of Words and Poetic Vocabulary in Asmat Songs.' In New Guinea Area Languages and Language Study, Vol. 3: Language, Culture, Society and the Modern World, edited by Stephen A. Wurm, 19-38. Pacific Linguistics, C 40. Canberra: The Australian National University.

Vormann, Franz. 1911. 'Tänze und Tanzfestlichkeiten der Monumbo-Papua (Deutsch-Neuguinea).' Anthropos 6: 411-27.

Wagner, Roy. 1967. The Curse of Souw. Chicago: University of Chicago Press.

- 1972. Habu: The Innovation of Meaning in Daribi Religion. Chicago: University of Chicago Press.

Waiko, John D. 1982. 'Be Jijimo: A History according to the Tradition of the Binandere People of Papua New Guinea.' PhD dissertation, The Australian National University.

—. 1984. 'Binandere Songs.' Bikmaus 5 (September): 87. 
. 1991. 'Literary Art Forms among the Binandere.' In Man and a Half: Essays in Pacific Anthropology and Ethnobiology in Honour of Ralph Bulmer, edited by Andrew Pawley, 369-75. Polynesian Society Memoir, 48. Auckland: Polynesian Society.

1995. 'Binandere Ario Dance and Music.' In New Guinea Ethnomusicology Conference: Proceedings, edited by Robert Reigle, 171-82. Occasional Papers in Pacific Ethnomusicology, 4. Auckland: University of Auckland.

Wassmann, Jürg. 1982. Der Gesang an den fliegenden Hund: Untersuchungen zu den totemistischen Gesängen und geheimen Namen des Dorfes Kandingei am Mittelsepik (Papua New Guinea) anhand der kirugu-Knotenschnüre. Basler Beiträge zur Ethnologie, 22. Basel: Ethnologisches Seminar der Universität und Museum für Völkerkunde.

. 1988. Der Gesang an das Krokodil: Die rituellen Gesänge des Dorfes Kandingei an Land und Meer, Pflanzen und Tiere (Mittelsepik, Papua New Guinea). Basler Beiträge zur Ethnologie, 28. Basel: Ethnologisches Seminar der Universität und Museum für Völkerkunde.

. 1991. The Song to the Flying Fox: The Public and Esoteric Knowledge of the Important Men of Kandingei about Totemic Songs, Names and Knotted Cords (Middle Sepik, Papua New Guinea). Translated by Dennis Q. Stephenson. Edited by Don Niles. Apwitihire: Studies in Papua New Guinea Musics, 2. Boroko: National Research Institute.

Webb, Michael, and Don Niles. 1986. Riwain! Papua New Guinea Pop Songs. Institute of Papua New Guinea Studies IPNGS 007. Two cassettes and book.

- 1990. Ol Singsing bilong Ples. Boroko: Institute of Papua New Guinea Studies IPNGS 010. Two cassettes and book.

Weiner, James F. 1988a. The Heart of the Pearl Shell: The Mythological Dimension of Foi Sociality. Studies in Melanesian Anthropology, 5. Berkeley: University of California Press.

. 1988b. 'Introduction: Looking at the New Guinea Highlands from Its Edge.' In Mountain Papuans; Historical and Comparative Perspectives from New Guinea Fringe Highlands Societies, edited by James F. Weiner, 1-38. Ann Arbor: University of Michigan Press.

- 1991. The Empty Place: Poetry, Space, and Being among the Foi of Papua New Guinea. Bloomington: Indiana University Press.

- 1993. 'To Be at Home with Others in an Empty Place: A Reply to Mimica.' Australian Journal of Anthropology 4: 233-44. 
. 1995. The Lost Drum: The Myth of Sexuality in Papua New Guinea and Beyond. Madison: University of Wisconsin Press.

. 1998a. 'Foi Memorial Songs.' In Australia and the Pacific Islands, edited by Adrienne L. Kaeppler and J. W. Love, 339-40. The Garland Encyclopedia of World Music, 9. New York: Garland Publishing.

. 1998b. 'Gender, Embodiment, and Movement in Foi Song.' In Australia and the Pacific Islands, edited by Adrienne L. Kaeppler and J. W. Love, 246-47. The Garland Encyclopedia of World Music, 9. New York: Garland Publishing.

- 2001. Tree Leaf Talk: A Heideggerian Anthropology. Oxford: Berg.

Welsch, Robert L. 2006. 'Coaxing the Spirits to Dance.' In Coaxing the Spirits to Dance: Art and Society in the Papuan Gulf of New Guinea, edited by Robert L. Welsch, 4-45. Hanover, NH: Hood Museum of Art.

Whiteman, Josephine. 1965. 'Girls' Puberty Ceremonies amongst the Chimbu.' Anthropos 60/1-6: 410-22.

Williams, Francis E. 1924. The Natives of the Purari Delta. Territory of Papua, Anthropology Report, 5. Port Moresby: Government Printer.

. 1936. Papuans of the Trans-Fly. Territory of Papua, Anthropology Report, 15. Oxford: Clarendon Press.

- 1939. 'A Cycle of Ceremonies in Orokolo Bay.' Mankind 2/6 (May): 145-55.

-1940. Drama of Orokolo: The Social and Ceremonial Life of the Elema. Territory of Papua, Anthropology Report, 18. Oxford: Clarendon Press.

—. 1940-42. 'Natives of Lake Kutubu, Papua.' Oceania 11: 121-57, 25994, 374-401; 12: 49-74, 134-54. [also appears in Francis Edgar Williams: 'The Vailala Madness' and Other Essays, edited by Erik Schwimmer (Honolulu: University Press of Hawaii, 1977)].

- 1977. 'Natives of Lake Kutubu, Papua.' In Francis Edgar Williams: 'The Vailala Madness' and Other Essays, edited by Erik Schwimmer, 161330. Honolulu: University Press of Hawaii. (originally published in Oceania 11 (1940): 121-57, 259-94, 374-401; 12:49-74, 134-54).

Wolffram, Paul. 2007. 'Langoron: Music and Dance Performance Realities among the Lak People of Southern New Ireland, Papua New Guinea.' PhD dissertation, Victoria University, Wellington. 
Wood, Michael. 1982. 'Kamula Social Structure and Ritual.' PhD dissertation, Macquarie University.

Yamada, Yōichi. 1997. Songs of Spirits: An Ethnography of Sounds in a Papua New Guinea Society. Translated by Jun'ichi Ohno. Edited by Don Niles. With one compact disc. Apwitihire: Studies in Papua New Guinea Musics, 5. Boroko: Institute of Papua New Guinea Studies.

Young, Rosemary. 1968. 'Words under a Bushel.' Practical Anthropology 15 (September-October): 213-16.

Zahn, Heinrich. 1996. Mission and Music: Jabêm Traditional Music and the Development of Lutheran Hymnody. Translated by Philip W. Holzknecht. Edited by Don Niles. Apwitihire: Studies in Papua New Guinea Musics, 4. Boroko: Institute of Papua New Guinea Studies. 



\section{Index of Performers}

The names of the performers of the songs included in this volume are listed below.

Abeabo men's songs $1-5,27,33,37-39,43 ;$ d online examples 8-9

Abuyu men's songs 26, 35

Agiri men's songs 19, 21-22; J online examples 10-12

Ama'a women's songs 6-7; $\boldsymbol{J}$ online example 18

Ayadobo men's song 34

Bogo men's songs 13-15; J online example 10

Damu men's song 34

Dunubu men's song 26

Fahaisabo men's songs 16-18, 20, 42; J online examples 10-12

Garibi men's songs 9-10; J online examples 8-9

Gebo women's sago songs 3, 5; J online examples 3, 5

Gesa men's songs $11-12 ; \boldsymbol{d}$ online example 10

Gobero men's song 43

Gofe men's song 25

Habeyu men's song 23

Hasuabo men's songs 28-29

Hira men's song 23

Hobe men's song 25

Komo'o men's songs 30-32

Kora men's songs 9-10, 27, 39-41, 44; J online examples 8-9

Kunuhuaka women's sago songs 2, 4, 6-7; women's songs 1-5; J online examples 2, 4, 6-7, 13-17

Kuri men's songs 28-29

Kusabuyu men's song 36 
Songs of the Empty Place

Maniname men's song 24

Mare men's song 24

Memene men's songs 1-5, 38; J online examples 8-9

Midibaru men's songs 6-8; J online examples 8-9

Mu'ubiaka women's sago song 1 ; J online example 1

Muya men's songs 19, 21-22; J online examples 10-12

Nabu men's songs 13-15; J online example 10

Oromene men's songs 16-18, 20, 42; J online examples 10-12

Sariaba men's songs $11-12 ;$ J online example 10

Sega men's songs 33, 37, 40

Siyame women's sago songs 6-7 J online examples 6-7

Tari men's song 35

Viya men's songs 30-32

Wa'abiyu women's songs 1-5; J online examples 13-17

Wa'o men's songs 6-8; J online examples 8-9

Webirabo men's songs $36,41,44$

Yiakahua women's songs 6-7; J online example 18 


\section{List of Online Examples}

Although the main focus of this publication has been on the texts of Foi songs, the poetry is only part of the total performance. To better convey some other aspects, photographs and verbal descriptions are also included; the sound of these songs is illustrated by the online examples (http://press.anu.edu.au/titles/ monographs-in-anthropology/songs-of-the-empty-place/).

Note that in compiling this collection, occasional discrepancies may be found between the performances and the transcribed texts. There may appear to be different, missing, or too many words; lines may be absent; words may seem to be mispronounced, etc. Such variations may result from differences in sung and elicited language, varying interpretations of what is sung by different assistants, lines or words being inadvertently skipped, unnoticed errors, or a variety of other reasons. The beginning words of some songs are also clipped-a familiar problem to anyone who has tried to record music in context. It is likely that the missing words were supplied during transcription by someone at the performance and who was familiar with the performer's textual style and use of language, perhaps even the singer involved. Ideally we would like to have corrected such discrepancies, but any such attempts would have further delayed the already long-overdue publication of these materials. It was felt best to make the material available in its present form, where it can inspire and guide future research efforts.

The original recordings of the songs in this volume were all made between 1980 and 1988 by James F. Weiner on a Sony Walkman Professional audiocassette recorder. These 79 audio cassettes plus his field notebooks have been deposited in The Australian National University Archives (series 432: http://archivescollection.anu.edu.au/index.php/james-f-weiners-cassettes). Specifically for this project, the audio recordings were digitised by the Pacific and Regional Archive for Digital Sources in Endangered Cultures (PARADISEC). (http://catalog.paradisec.org.au/repository/JW1). For permission to access these digitised recordings, please contact James Weiner. For each online example below, reference is given to the original PARADISEC digitisation, noting in minutes and seconds where example begins in that recording.

The examples listed below have been selected in order to provide audio examples of the songs considered in this book. 


\section{Women's Sago Songs (Obedobora)}

Online example 1 (JW1-053-A.mp3, from 20:15)

Sago Song 1, performed by Mu'ubiaka

Online example 2 (JW 1-053-B.mp3, from 06:09)

Sago Song 2, performed by Kunuhuaka

Online example 3 (JW1-053-A.mp3, from 16:02)

Sago Song 3, performed by Gebo

Online example 4 (JW1-053-B.mp3, from 10:35)

Sago Song 4, performed by Kunuhuaka

Online example 5 (JW1-053-A.mp3, from 18:02)

Sago Song 5, performed by Gebo

Online example 6 (JW1-072-B.mp3, from 09:36)

Sago Song 6, performed by Kunuhuaka (with Siyame)

Online example 7 (JW1-072-B.mp3, from 14:16)

Sago Song 7, performed by Kunuhuaka (with Siyame)

\section{Men's Songs (Sorohabora)}

Online example 8 Sorohabora A (JW1-067-A.mp3, from 20:39) Men's Song 2, performed by Memene and Abeabo

Men's Song 7, performed by Wa'o and Midibaru

Men's Song 9, performed by Kora and Garibi

Online example 9 Sorohabora B (JW1-067-A.mp3, from 26:00)

Men's Song 3, performed by Memene and Abeabo

Men's Song 8, performed by Wa'o and Midibaru

Men's Song 10, performed by Kora and Garibi

Online example 10 Sorohabora C (JW1-067-A.mp3, from 31:32)

Men's Song 11, performed by Gesa and Sariaba

Men's Song 13, performed by Nabu and Bogo

Men's Song 17, performed by Oromene and Fahaisabo

Men's Song 19, performed by Muya and Agiri

Online example 11 Sorohabora D (first line slightly cut)

(JW1-068-A.mp3, from 05:42)

Men's Song 20, performed by Oromene and Fahaisabo

Men's Song 21, performed by Muya and Agiri

Online example 12 Sorohabora E (JW1-068-A.mp3, from 17:00)

Men's Song 42, performed by Fahaisabo and Oromene

Men's Song 22, performed by Muya and Agiri 


\section{Women's Songs (Sorohabora)}

Online example 13 (JW1-073-A.mp3, from 05:37)

Women's Song 1, performed by Kunuhuaka and Wa'abiyu Online example 14 (JW1-073-A.mp3, from 09:07)

Women's Song 2, performed by Kunuhuaka and Wa'abiyu Online example 15 (JW1-073-A.mp3, from 14:02)

Women's Song 3, performed by Kunuhuaka and Wa'abiyu Online example 16 (JW1-073-A.mp3, from 19:35)

Women's Song 4, performed by Kunuhuaka and Wa'abiyu Online example 17 (JW1-073-A.mp3, from 22:29)

Women's Song 5, performed by Kunuhuaka and Wa'abiyu Online example 18 (JW1-073-A.mp3, from 32:50)

Women's Song 7, performed by Yiakahua and Ama'a 
